Doctoral (Ph.D.) Dissertation

\title{
SYNTHESIS AND ENVIRONMENTAL APPLICATIONS OF MANGANESE OXIDES
}

\section{Ochirkhuyag Altantuya}

\author{
Supervisor: \\ Prof. Dr. Kónya Zoltán
}

Doctoral School of Environmental Sciences

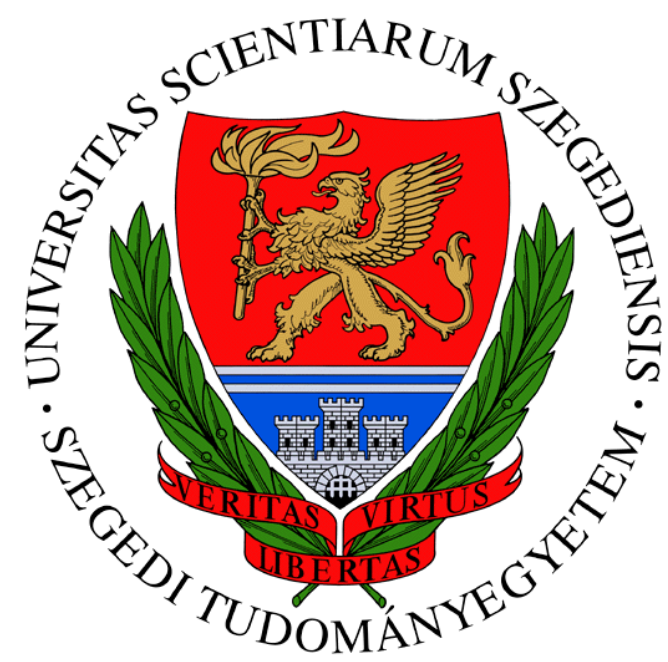

University of Szeged

Faculty of Science and Informatics

Department of Applied and Environmental Chemistry

Szeged, 2021 


\section{Table of Contents}

Table of Contents .........................................................................................................ii

List of Abbreviations.......................................................................................

List of Figures ......................................................................................................................

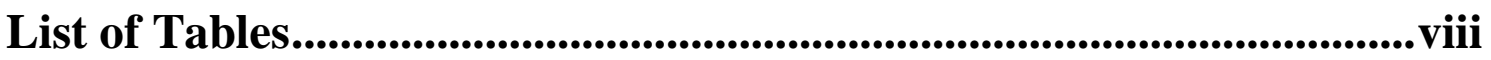

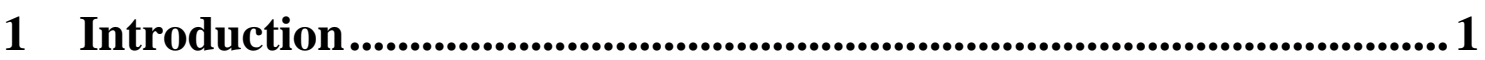

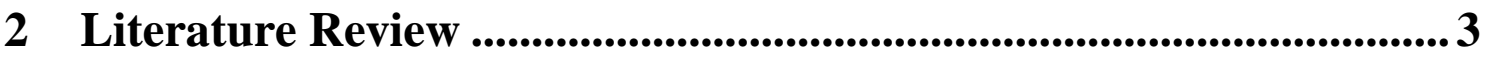

2.1 Environmental problems and attempts to solve them ....................................3

2.1.1 Lack of fossil fuel reserves and sustainable energy sources............................... 3

2.1.2 Fuel cell (HOR and ORR)............................................................................... 4

2.1.3 $\mathrm{CO}_{2}$ capture (hydrogenation) ........................................................................... 5

2.1.4 Efficient energy storage devices (supercapacitor)............................................... 6

2.2 Physico-chemical properties of the manganese and its derivatives ...........7

2.2.1 Electronic and physical properties........................................................................ 7

2.2.2 Oxidation states and electrochemical properties................................................ 7

2.2.3 Crystal structures of the manganese oxides ..................................................... 10

2.3 Natural occurrence and synthesis methods ..................................................13

2.3.1 Natural origin and occurrence ………………………………………………….... 13

2.3.2 The synthesis methods................................................................................... 15

2.3.2.1 Redox reaction in aqueous media......................................................... 15

2.3.2.2 Electrolytic deposition...................................................................... 16

2.3.2.3 Electrophoretic deposition …………………………………………....... 17

2.3.2.4 Mechanochemical ball milling method ……………………………….... 18

2.3.2.5 Synthesis from the natural mineral............................................................ 19

2.4 Applications of the manganese oxides ............................................................20

2.4.1 Production of the manganese and general applications..................................... 20

2.4.2 Manganese oxides catalysts ............................................................................ 21

2.4.2.1 Manganese oxide catalyst for ORR ............................................................ 22

2.4.2.2 Manganese oxide catalyst for $\mathrm{CO}_{2}$ hydrogenation.................................... 23

2.4.3 Manganese oxide electrode for supercapacitor................................................. 25

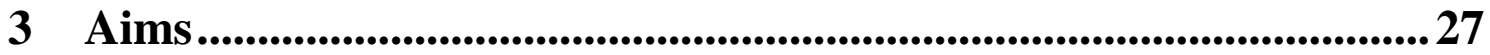

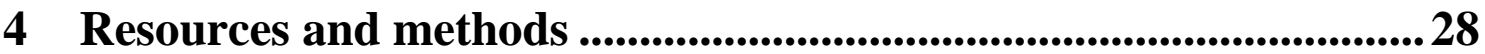

4.1 Materials ...............................................................................................................28

4.2 Synthesis of different manganese oxides .......................................................28

4.2.1 Synthesis of ion-tuned birnessite in alkaline media........................................... 29

4.2.2 Synthesis of manganese oxide using a ball milling method ............................... 29

4.2.3 Synthesis of manganese oxide nanostructures from the mineral....................... 30

4.3 Characterization techniques........................................................................32

4.4 Methods and electrochemical experiment setup .........................................34 
4.4.1 The catalyst for oxygen reduction reaction (ORR) .......................................... 34

4.4.1.1 Electrode preparation for oxygen reduction reaction $(\mathrm{ORR})$...................... 34

4.4.1.2 Electrochemical oxygen reduction reaction test ......................................... 34

4.4.1.3 Electrochemical stability of the Birnessite ................................................. 35

4.4.2 Catalytic $\mathrm{CO}_{2}$ hydrogenation reaction over manganese-oxide catalysts ........... 35

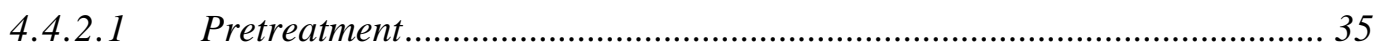

4.4.2.2 Hydrogenation of carbon dioxide in a continuous flow reactor ................. 35

4.4.3 Electrochemical electrode preparation for capacitance test (CV, GCD, EIS) . 35

5 Results and discussions....................................................................36

5.1 Characterization results of the manganese oxides ...................................36

5.1.1 Characterization results of the Birnessite in alkaline media .............................. 36

5.1.1.1 Structural determination and chemical characterization .............................. 36

5.1.1.2 Morphology and surface property characterization ................................... 38

5.1.2 Characterization results of the ball-milled manganese oxides .......................... 42

5.1.2.1 Mechanochemical synthesis and energy calculation............................... 42

5.1.2.2 Structural determination and chemical characterization............................. 44

5.1.2.3 Morphology and surface property characterization .................................. 46

5.1.3 Characterization results of deposited manganese oxide from natural ore....... 49

5.1.3.1 Structural determination and chemical characterization............................. 49

5.1.3.2 Morphology and surface property characterization ................................. 52

$5.2 \quad$ Application test results and discussions ................................................53

5.2.1 Oxygen reduction reaction (ORR) catalyst Birnessite ...................................53

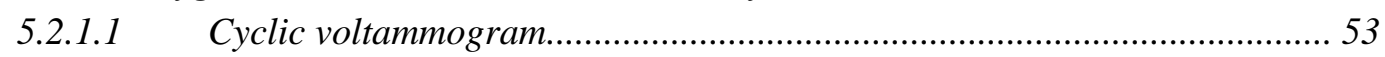

5.2.1.2 Linear sweep voltammetry and electron transfer number ............................ 54

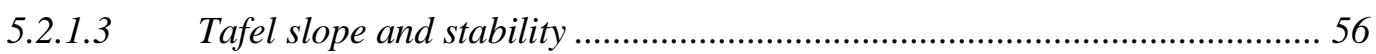

5.2.2 Carbon dioxide hydrogenation catalyst ball-milled $\mathrm{MnOx}$...............................57

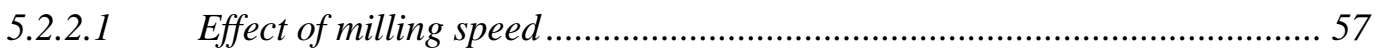

5.2.2.2 Effect of one-pot loading of Pt and $\mathrm{Cu}$ doped catalysts .............................. 59

5.2.2.3 Effect of Platinum incorporation................................................................ 59

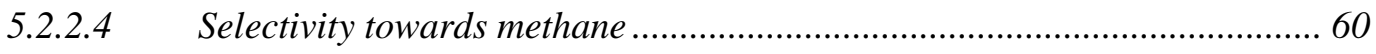

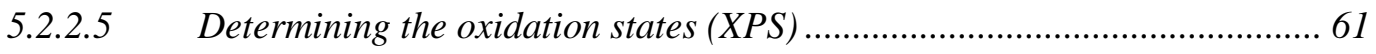

5.2.3 Manganese mineral oxide supercapacitor electrode .........................................64

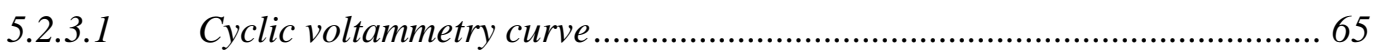

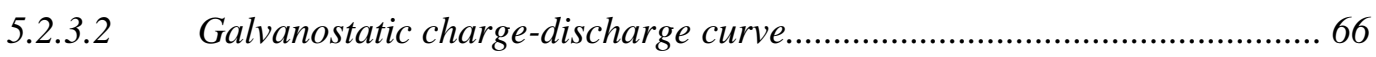

5.2.3.3 Electrochemical impedance spectroscopy analysis...................................6 67

6 Conclusion.............................................................................69 69

Összefoglalás.............................................................................................. 71

7 References and notes............................................................. 73

Acknowledgements ..............................................................................8 86

Publication list ....................................................................................... 87 


\section{List of Abbreviations}

EIA

IEA

TW

FT

ORR

HOR

IPCC

$\mathrm{kWh}$

$\mathrm{Tb}$

TCF

BT

RWGS

CFSE

$\mathrm{Mb}$

BCF

EDLCs

EMD

ITO

PVP

MW

Wt.\%

At \%

EMF

EMM

$\mathrm{PtG}$

XPS

XRD

TG

DLS

DSC

BET

TC

FID

RDE

RHE

SHE

GCE

TEM

SEM

GCD

EIS

CV

LSV

EDS
Energy Information Administration

International Energy Agency

Terawatt

Fischer-Tropsch

Oxygen reduction reaction

Hydrogen oxidation reaction

Intergovernmental Panel on Climate Change

Kilowatt-hour

Thousand Barrels

Trillion cubic feet

Billion tones

Reverse Water-Gas Shift reaction

Crystal Field Stabilization Energy

Million Barrels

Billion cubic feet

Electrical double-layer capacitors

Electrolytic manganese dioxides

Indium thin oxide

Polyvinylpyrrolidone

Molecular weight

Weight percentage

Atomic percentage

External magnetic field

Electrolytic manganese metal

Power-to-gas

X-ray photoelectron spectroscopy

$\mathrm{X}$-ray diffractometry

Thermogravimetry

Dynamic light scattering

Differential scanning calorimetry

Brunauer-Emmett-Teller

Thermal conductivity

Flame ionization detector

Rotating disk electrode

Reversible hydrogen electrode

Standard hydrogen electrode

Glassy carbon electrode

Transmission Electron Microscopy

Scanning Electron Microscopy

Galvanostatic charge-discharge

Electrochemical impedance spectroscopy

Cyclic voltammetry

Linear sweep voltammetry

Energy-dispersive X-ray spectroscopy 


\section{List of Figures}

Figure 1. Illustration of the alkaline fuel cell with an overview of the chemical reactions [16].

Figure 2. Ragone plot of the energy storage domains for the various electrochemical energy conversion systems compared to an internal combustion engine and turbines and conventional capacitors [35].

Figure 3. Electronic configuration and common oxidation state varieties of d-block elements including $\mathrm{Mn}$ in the middle of the column.

Figure 4. Eh-pH diagram shows the predominant manganese forms and $\mathrm{Mn}-\mathrm{H}_{2} \mathrm{O}$ systems. Temperature, $25^{\circ} \mathrm{C} \pm 0.5[42]$.

Figure 5. The octahedral unit cell and crystal structure of the polymorphs of the manganese dioxides illustrated by the VESTA visualization program using data from the Crystallography Open Database.

Figure 6. Schematic diagram of (a) triclinic Na-birnessite and (b) hexagonal H-birnessite [51]. Figure 7. Hausmannite cell unit with 28 atoms (a) $\mathrm{Mn}^{2+}$ tetrahedral and $\mathrm{Mn}^{3+}$ octahedral sites and (b) the detailed structure of the different Mn sites [52].

Figure 8. Manganese occurrence (Earth crust and ocean nodules) and typical minerals (mineral photos from [57]) in sedimental rock.

Figure 9. Location of the Úrkút manganese ore deposit.

Figure 10. Synthesis routes between various manganese oxides [61].

Figure 11. Four steps of EPD; (a) dispersion, (b) electrochemical charging, (c) electrophoresis and (d) deposition [64].

Figure 12. The illustration of a chemical reaction during the mechanical ball milling process [68].

Figure 13. Manganese applications by weight percentage and list of other applications not related to metal production.

Figure 14. Proposed oxygen reduction mechanism over Mn(IV) oxide catalyst' [Mn (III) sites (green) and $M n(I V)$ sites (red)] [111].

Figure 15. Product fraction of $\mathrm{CO}_{2}$ hydrogenation at equilibrium [123].

Figure 16. a) Associative mechanism of $\mathrm{CO}$ formation including A-formation of $\mathrm{HCOO}$ intermediate and $B$-formation of $\mathrm{COOH}$ intermediate and $b$ ) reaction mechanisms possible for the methanation of $\mathrm{CO}_{2}$ including A-associative methanation, $B$-dissociative methanation, $C$ CO associative pathway, D-CO dissociative pathway [126].

Figure 17. The working mechanism of the $\mathrm{MnO}_{2}$ based symmetric supercapacitor [130].

Figure 18. Manganese solution in oxalic acid (I), manganese solution with sodium hydroxide in pH 3-4 (II), the electrochemical formation of $\mathrm{Mn}(\mathrm{OH})_{2}$ at the cathode and electrophoretic movement toward the anode (III), and deposited final product on anode after 3 hours (IV). Figure 19. X-ray diffraction patterns ( $a$ - $b$ ) \{XRD patterns: *-birnessite, $\boldsymbol{\alpha}$ - tunnel structured $\left(\mathrm{MnO}_{2}\right), \Delta$ - manganite $\left.\mathrm{MnO}(\mathrm{OH})\right\}$ and illustration of interlayer distance and intercalated cations of the Birnessite (c) and $\mathrm{Cu}^{2+} /$ Birnessite $(d)$.

Figure 20. Raman spectra (a) Birnessite $565 \mathrm{~cm}^{-1}$ (in-plane stretch) $697 \mathrm{~cm}^{-1}$ (out-of-plane stretch), and EDS spectra (b) of the pristine birnessite as well as the copper-ion intercalated birnessite structure.

Figure 21. Thermal decomposition of a) Birnessite and b) $\mathrm{Cu}^{2+} / \mathrm{Birnessite}$ both in the air and nitrogen atmosphere at $R T-750^{\circ} \mathrm{C}$ with a heating rate of $5{ }^{\circ} \mathrm{C} / \mathrm{min}$

Figure 22. Differential scanning calorimetric analysis results of samples at $600{ }^{\circ} \mathrm{C}$ with heating and cooling rate $5{ }^{\circ} \mathrm{C} / \mathrm{min}$. 
Figure 23. $\mathrm{N}_{2}$ adsorption-desorption isotherms (a), and pore diameter of the Birnessite samples (b).

Figure 24. Characterization of the Birnessite (a) by the $\mathrm{pH}$-dependent zeta potential $(\zeta)$ and hydrodynamic diameter $\left(Z_{A V E}\right)$ at $10 \mathrm{mmol} \mathrm{L}^{-1} \mathrm{NaCl}$. Effect of $\mathrm{Cu}$ ion addition on $(b)$ the zeta potential and (c) the hydrodynamic diameter of the Birnessites particles at $10 \mathrm{mmol} \mathrm{L} \mathrm{L}^{-1} \mathrm{NaCl}$.

Figure 25. Typical SEM images ( $a-b)$ and TEM images ( $c-d)$, and HR-TEM images of the birnessite samples (e-f). The images created from undoped Birnessite samples on the left (a,c,e) and $\mathrm{Cu}^{2+} /$ Birnessite samples on the right $(b, d, f)$.

Figure 26. Schematic view of the motion of the ball and powder mixture in the high-energy ball milling process (a) and milling-map of samples, displaying the grounding process with different ball-impact $\left(E_{b}\right)$ and cumulative energy $\left(E_{\text {cum }}\right)$ which is dependent on the rotational speed $\left(W_{v}\right)$ (b). All the samples were milled for 4 hours.

Figure 27. X-ray diffraction patterns of the pure samples (a) $\left\{\right.$ * birnessite type $\sigma-\mathrm{MnO}_{2}$, $\mathrm{Mn}_{3} \mathrm{O}_{4}$ phase and Raman spectra of samples $(b)$.

Figure 28. X-ray diffraction patterns of the metal (Pt and $\mathrm{Cu}$ ) doped samples $(a-c)$ and their Raman shifts( $d-f)$.

Figure 29. $N_{2}$ adsorption analysis full isotherm (a) and the pore radius of the pure samples calculated from BET evaluation of $\mathrm{N}_{2}$ adsorption-desorption isotherms (b).

Figure 30. Thermal decomposition of the pure samples at a heating rate of $5{ }^{\circ} \mathrm{C} \mathrm{min}-1$ in the air (a) and in nitrogen (b).

Figure 31. X-ray diffraction patterns of the samples after TGA analysis: a) M200, b) M450, and v) $M 600$.

Figure 32. Differential scanning calorimetry results of the milled samples at $600{ }^{\circ} \mathrm{C}$.

Figure 33. Scanning electron microscopic images (SEM) and Transmission electron microscopic (TEM) images of the pure samples (a-b) M200, (b-c) M450 and (e-f) M600.

Figure 34. X-ray diffraction patterns of the MnOx-M and MnOx-I (a), and carbon paper and $M n O x-D$ deposited on carbon paper (b), Raman spectra of the MnOx-M and MnOx-I (c), and carbon paper and $\mathrm{MnOx}-\mathrm{D}$ deposited on carbon paper $(d)$.

Figure 35. EDS-mapping used SE (second elementary image) of the MnOx-M (a-b) and MnOx$D$ deposited on carbon paper $(\mathrm{MnOx}-\mathrm{D} / \mathrm{CP})(\mathrm{c}-\mathrm{d})$.

Figure 36. Scanning electron microscopic image of the samples; a) MnOx-I, b) MnOx-D/CP, c) $M n O x-M$ at higher magnification and d) $M n O x-D / C P$ at higher magnification. Transmission electron microscopic image of $\mathrm{MnOx}-\mathrm{M}(\mathrm{e})$ and $\mathrm{MnOx}-\mathrm{D} / \mathrm{CP}(f)$.

Figure 37. Cyclic voltammograms of the GCE electrodes modified with the as-prepared (a) Birnessite samples, and (b) $\mathrm{Cu}^{2+} /$ Birnessite samples. All measurements were carried out in $0.1 \mathrm{M} \mathrm{KOH}$ solution at $10 \mathrm{mVs}^{-1}$ scan rates.

Figure 38. LSV curves of the GCE modified with (a) Birnessite and (b) $\mathrm{Cu}^{2+} /$ Birnessite.

Koutecky-Levich plots of GCE modified with (c) Birnessite, and (d) $C u^{2+} /$ Birnessite obtained from rotating disk electrode LSV measurements.

Figure 39. LSV curves of the as-prepared sample measured at $1500 \mathrm{rpm}$ (a) and summary of the calculated electron transfer numbers (b). All measurements were carried out in $0.1 \mathrm{M} \mathrm{KOH}$ solution at $10 \mathrm{mVs}^{-1}$ scan rates.

Figure 40. (a) Tafel slopes derived from LSV data and (b) Stability measurement of the samples measured at 0,4V (vs RHE) in oxygen saturated electrolyte at 1500 rpm rotating rate. All measurements were carried out in $0.1 \mathrm{M} \mathrm{KOH}$ solution at $10 \mathrm{mVs}^{-1}$ scan rates.

Figure 41. The $\mathrm{CO}_{2}$ consumption rate of manganese oxides synthesized by different milling speed (200 rpm-M200, $450 \mathrm{rpm}-M 450$ and $600 \mathrm{rpm}-\mathrm{M600})$ as a function of temperature (a) and function of time $(b)$. 
Figure 42. X-ray diffraction patterns of the samples $\left\{\left\{{ }^{*}\right.\right.$ birnessite type $\sigma-\mathrm{MnO}_{2},-\mathrm{Mn}_{3} \mathrm{O}_{4}$ phase, $\triangle-\mathrm{MnO}$ phase\} pretreated (a) and after $\mathrm{CO}_{2}$ hydrogenation test ( $b$ ).

Figure 43. Temperature effect for the $\mathrm{CO}_{2}$ consumption rate of the samples at (a) $673 \mathrm{~K}$ and (b) $873 \mathrm{~K}$.

Figure 44. The $\mathrm{CO}_{2}$ consumption rate of the Pt-doped M600 manganese-oxide prepared by the one-pot method, incipient wetness impregnation method as well as designed incorporation of controlled-sized $5 \mathrm{~nm}$ Pt nanoparticles as a function of temperature (a) and function of time (b).

Figure 45. The selectivity of methane during $\mathrm{CO}_{2}$ hydrogenation reaction in the case of $(a)$ pure, Pt-loaded, and Cu-loaded catalysts prepared by using different milling speed and (b) M600 loaded with Pt by different methods.

Figure 46. The collected Mn 2p 3/2 spectra of the different MnOx samples, (a) M200 after pretreatment, (b) M600 after pretreatment, (c) Pt-milled M600 after pretreatment and (d) M200 after the reaction (e) M600 after the reaction, (f) Pt-milled M600 after the reaction.

Figure 47. Atomic ratios of $\mathrm{Mn}$ with different oxidation states before $\mathrm{CO}_{2}$ hydrogenation (after pretreatment) and after $\mathrm{CO}_{2}$ hydrogenation reactions for (a) M200, (b) M600, and (c) Pt-milled M600.

Figure 48. a) the cyclic voltammetry curve of the bare carbon paper electrode and $\mathrm{MnOx}-\mathrm{D} / \mathrm{CP}$ electrode at $0.03 \mathrm{~V} / \mathrm{sec}$ scan rate and $b)$ different scan rates $(0.005,0.01,0.03$ and $0.05 \mathrm{~V} / \mathrm{sec})$ for $\mathrm{MnOx}-\mathrm{D} / \mathrm{CP}$.

Figure 49. $C V$ curve in a different number of a cycle (a) and specific capacitance retention from the cyclic voltammetry curve by different cycling number(b).

Figure 50. Galvanostatic charge-discharge curve of $\mathrm{MnOx}-\mathrm{D} / \mathrm{CP}$ with $0.6 \mathrm{~A} / \mathrm{g}$ current density (a) and different current densities such as $2 \mathrm{~A} / \mathrm{g}, 1 \mathrm{~A} / \mathrm{g}, 0.6 \mathrm{~A} / \mathrm{g}$ and $0.1 \mathrm{~A} / \mathrm{g}(b)$.

Figure 51. Nyquist plot of the bare carbon electrode (a) and $\mathrm{MnOx-D/CP}$ electrode (b).

Figure 52. Bode plot of the $\mathrm{MnOx}-\mathrm{D} / \mathrm{CP}$ electrode the frequency versus real impedance (a) and phase degree $(b)$. 


\section{List of Tables}

Table 1. Global fossil fuel statistics based on discovered reserves.

Table 2. Redox potentials for manganese ions in aqueous solutions.

Table 3. The price of the metals in the market (USD per kilogram).

Table 4. The synthetic procedure of the manganese-oxide samples.

Table 5. The chemical component ratio of the birnessite samples from EDS analysis

Table 6. Composition of the manganese oxide catalysts evaluated from SEM-EDS data.

Table 7. Specific surface area results of the ball-milled manganese-oxide samples

Table 8. Quantitative chemical analysis result (wt.\%) of the samples.

Table 9. Manganese oxide-based catalysts and Cu doped different support catalysts for ORR.

Table 10. Reaction rates (at $673 \mathrm{~K}$ and $873 \mathrm{~K}$ ) and the activation energies for $\mathrm{CO}_{2}$

hydrogenation reactions over the samples at $873 \mathrm{~K}$

Table 11. The catalytic results of the Pt loaded M600 at 673K (one-pot milled, wet impregnated, and sonicated)

Table 12. Comparison of $\mathrm{CO}_{2}$ conversion percentage (Pt loaded samples) with previously published references at different temperatures.

Table 13. The specific capacitance of the MnOx-D/CP from the cyclic voltammetry analysis.

Table 14. The specific capacitance of the $\mathrm{MnO}_{x}$-D/CP from the galvanostatic charge-discharge measurement. 


\section{Introduction}

Sustainable energy production is the key to the future of humanity as electrical energy demands continue to rise to newer heights and fossil fuel reserves like natural gas, oil, and coal are slowly diminishing. More than $80 \%$ of the global principal energy source today is fossil fuels based. Some new studies [1] suggest that humans may consume all discovered reserves of fossil fuels within a few decades, although, future discoveries of fossil fuel reserves might prolong this process. Following the trends of the last century, electrical energy demand is rising exponentially. According to the statistical data of the US Energy Information Administration (EIA) and the International Energy Agency (IEA), the global electricity consumption, including transportation, industry, residential and commercial use was about 10,000 TWh in 1990, 14,000 TWh in 2000, and 24,000 TWh in 2018 with rapidly increasing trends [2]. Electrical energy growth can be attributed to many factors, like emerging new technologies, increasing automation in agriculture, and the growing global population. This all causes an exponential increase in demand for fossil fuel as the natural reserves are dwindling at an ever-growing pace.

Due to these problems, scientists are focusing on finding new sustainable electrical energy production based on renewable energy sources like solar, geothermal heat and wind. Considerable research is also being performed to develop fuel cell technologies, to allow for the storage and transportation of the generated energy. The fuel cell is an electrochemical cell that converts the chemical energy of a fuel (often hydrogen) and an oxidizing agent (often oxygen) into electricity through a pair of redox reactions [3], with water as a byproduct. Fuel cells are made up of three adjacent segments: the anode, the electrolyte, and the cathode. Electrons are freed by the chemical energy, then they travel through a wire creating an electric current. In a fuel cell system, energy is stored chemically. During the release of this energy two processes take place: oxygen reduction reaction (ORR) and hydrogen oxidation reaction (HOR). These reactions together produce water from oxygen and hydrogen gas, which are nonspontaneous and require an efficient catalyst. The most common catalysts for the ORR are noble metal catalysts such as Pt, Ir, and Ru. These catalysts have high efficiency and stability; however, they also have drawbacks such as high price and rarity in nature [4]. Consequently, significant research is being conducted to find a cheap, common, and environmentally friendly catalyst for ORR.

The temperature on Earth is dependent on three main factors: how much sunlight gets captured by Earth, how much geothermal heat is generated, and how much heat Earth radiates away. Greenhouse gases are absorbing in a specific band in the infrared region, which prevents Earth from losing some of its heat. The $\mathrm{CO}_{2}$ greenhouse gas is part of the natural carbon cycle, however, in the last 300 years, the average amount of $\mathrm{CO}_{2}$ in the Earth's atmosphere increased by a factor of two. The burning of fossil fuels emits $\mathrm{CO}_{2}$ as the main product ranging from 0.5 to 
$1.1 \mathrm{~kg} \mathrm{CO}_{2}$ for every $\mathrm{kWh}$ energy generated [5]. The enormous increase of greenhouse gases in the atmosphere creates health issues, causes economic crises, and affects extreme global warming. At current emission rates, temperatures could increase by $2{ }^{\circ} \mathrm{C}\left(3.6^{\circ} \mathrm{F}\right)$, which the United Nations' Intergovernmental Panel on Climate Change (IPCC) designated as the upper limit to avoid "dangerous" levels, by 2036 [6]. Capturing carbon dioxide from the atmosphere is a promising candidate in next-generation energy source production since valuable fuels $\left(\mathrm{CO}, \mathrm{CH}_{4}\right.$, $\mathrm{CH}_{3} \mathrm{OH}$ ) can be produced this way, the environmental stress can be reduced as well [7,8]. Just as for the ORR process, research is underway to identify the stable and cost-effective catalyst for $\mathrm{CO}_{2}$ hydrogenation.

The imbalance between energy demand and energy production fluctuates in time, thus an efficient way is needed to store energy when demand is low and use it later when demand is high. There is a great incentive to replace conventional acid batteries with eco-friendly materials requiring less recharge time, do not utilize hazardous acids, and are abundant in nature. Further research is also underway to manufacture more effective, safe, and long-life cycle energy storage devices such as metal oxide-based supercapacitors.

To find answers to all these questions, Manganese (Mn) was selected as the subject of my research, since it is cheap and it is one of the most abundant transition metal (after iron) in the Earth's crust. Due to a wide variety of oxidation states and crystal structures, manganese can have many morphological and physicochemical attributes, therefore, it can be a component for numerous applications. As an environmental chemist, I am focused on the environmentally friendly, cost-effective, safe, simple, and effective synthesis of the materials utilized in various applications aimed to protect the environment. I synthesized different manganese oxides using the simplest synthetic methods such as cost-effective redox reaction in alkaline media, one-pot mechanochemical method combination of mechanical milling and redox reaction, and direct electrophoretic deposition from the mineral. I have also characterized these synthesized manganese oxides and tested them for the previously mentioned applications, as the catalyst of the oxygen reduction reaction (ORR), as a catalyst of the carbon dioxide $\left(\mathrm{CO}_{2}\right)$ hydrogenation, and as an electrode material for supercapacitors. 


\section{Literature Review}

\subsection{Environmental problems and attempts to solve them}

\subsubsection{Lack of fossil fuel reserves and sustainable energy sources}

The world's most pressing concern today is the rapid exhaust of conventional energy sources such as oil, gas and coal [9]. Due to rises in the population, energy demand is increasing exponentially with a rapid rate of the world population. However, currently identified reserves of fossil fuels will be gone within the next few decades, although this can be prolonged depending on the newly discovered resources. Global fossil fuels statistics of total reserves, production per day and predicted ending date are shown in Table 1. The total stock of oil, gas and coal are approximated to be 1.689 trillion barrel (Tb), 6558 trillion cubic feet (TCF), and 891.531 billion tons (BT), respectively. Interpolation from current data suggests, that the current oil supply will be gone by the year 2066 and the coal source will be depleted by 2126 [1].

Table 1. Global fossil fuel statistics based on discovered reserves.

\begin{tabular}{llll}
\hline Fuels & Total reserves (2015) & Production/day (2015) & End(date) $^{\mathbf{a}}$ \\
\hline Oil & $1.689 \mathrm{~Tb}$ & $86.81 \mathrm{Mb}$ & 2066 \\
Gas & $6558 \mathrm{TCF}$ & $326 \mathrm{BCF}$ & 2068 \\
Coal & $891.531 \mathrm{BT}$ & $21.63 \mathrm{MT}$ & 2126 \\
\hline
\end{tabular}

${ }^{\mathrm{a}}$ End dates may shift if more natural reserves are found.

However, renewable energy sources such as wind, solar, hydro, biomass, geothermal energy are being developed and they are being used at an industrial scale. Still, these efforts are not enough to replace fossil fuel energy production in the foreseeable future. The renewable sources all bring us only $20 \%$ of energy [10], this statistic is going to increase with time but most of these renewable energy sources rely on uncontrollable natural phenomena. For example, solar energy is a promising candidate for energy production, although it is dependent on the time of the day, the season of the year, and the geological location as well. The hydro and geothermal energies provide a more stable output of energy, but the cost of the processing is high, balancing the electricity grid is complicated, and sometimes it is harmful to various animal species (birds, fishes) [11]. Therefore, further improvement of energy conversion and finding efficient storage devices is vital. Here are the three most promising electrochemical process involved ways for efficient and eco-friendly energy conversion and energy storage:

- Fuel cell technology

- Carbon dioxide conversion

- Supercapacitor 


\subsubsection{Fuel cell (HOR and ORR)}

One of the most promising technologies of the sustainable energy industry is the fuel cell. The fuel cell is a galvanostatic type of electrochemical cell that converts chemical energy to electrical energy. The electrochemical energy conversion in a fuel cell is a promising candidate for the sustainable energy production industry $[12,13]$ due to a wide range of applications, its high energy efficiency $[14,15]$, and common feeding materials such as hydrogen and oxygen. There are many types of fuel cells, but they all consist of an anode, a cathode, and an electrolyte. Two chemical reactions occur at the intersection of these three different components. The net result of the two reactions that the fuel is consumed, water or carbon dioxide is created, and an electric current is generated, which can be used to power electrical devices. Hydrogen fuel cells can produce electricity continuously for as long as fuel (hydrogen) and oxygen are supplied. At the anode, a catalyst causes the fuel to undergo oxidation reactions (HOR) that generate ions (often positively charged hydrogen ions) and electrons. The ions move from the anode to the cathode through the electrolyte. At the same time, electrons flow from the anode to the cathode through an external circuit, producing a direct electric current. At the cathode, a different catalyst causes ions, electrons, and oxygen to react, forming water and possibly other products (ORR).

The electrochemical fuel cell technology includes two key steps are shown in Figure 1: HOR and ORR. Nevertheless, both half-reactions at anode and cathode require catalysts; the most common catalysts for ORR are noble metals like platinum (Pt), iridium (Ir), and ruthenium (Ru). However, these noble metal catalysts are extremely expensive and do not meet the requirements of sustainable energy production. Therefore, the development of ORR (or HOR) with different catalysts is crucial for efficient and eco-friendly energy construction.

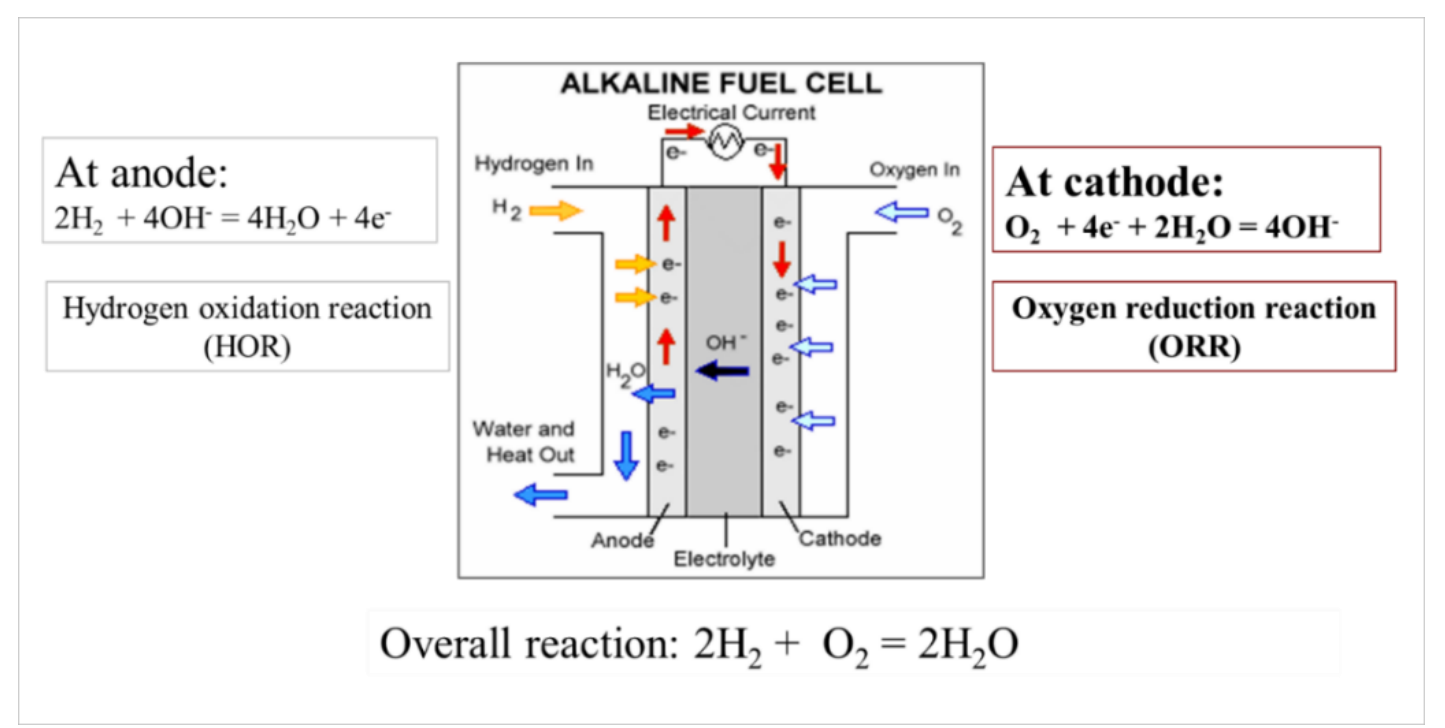

Figure 1. Illustration of the alkaline fuel cell with an overview of the chemical reactions [16]. 


\subsection{3 $\mathrm{CO}_{2}$ capture (hydrogenation)}

The increasing environmental pollutions from the byproducts of fossil fuels and greenhouse gas emissions from fossil fuel combustion [17] are a few of the many problems caused by the fossil fuel industry. The primary greenhouse gases in the Earth's atmosphere are carbon dioxide $\mathrm{CO}_{2}$, water vapour $\mathrm{H}_{2} \mathrm{O}$, methane $\mathrm{CH}_{4}$, nitrous oxide $\mathrm{N}_{2} \mathrm{O}$, and ozone $\mathrm{O}_{3}$, which are keeping Earth's atmosphere warmer. But human activities since the beginning of the Industrial Revolution (about 1700) have produced a $45 \%$ increase in the atmospheric concentration of carbon dioxide, from $280 \mathrm{ppm}$ in 1750 to $410 \mathrm{ppm}$ in 2018, which caused global temperature rises in an average of 0.5 Celsius [18]. Even if this temperature change seems small, it extremely affects the weather in particular areas like Antarctica, where it is causing mass extinctions, melting of the ice sheets, rising the sea level, and even desertification in some countries. Most of the $\mathrm{CO}_{2}$ emission stems from fossil fuel burning, and if humans continue to use fossil fuels as an energy source, carbon dioxide emission will remain the leading source of pollution. As part of the Paris agreement in 2015, 196 countries decided to decrease $\mathrm{CO}_{2}$ emission by $70 \%$ by 2030 and limit temperature rises $1.5^{\circ} \mathrm{C}$ before 2100 [19]. But as mentioned before, fossil fuels won't be replaced shortly and energy demand will foreseeably increase even further, other ways must be explored to decrease carbon dioxide in the atmosphere, such as $\mathrm{CO}_{2}$ capture.

Carbon dioxide can be captured directly from the air or an industrial source using a variety of technologies, including adsorption, absorption, chemical looping, membrane gas separation or gas hydrate technologies [20]. New generation plants for $\mathrm{CO}_{2}$ hydrogenation are producing methanol with high conversion rates even reaching a production of 5500 tons/year [21]. New methods are being explored to produce $\mathrm{C}_{5+}$ hydrocarbons, however, industrial production has not yet started $[22,23]$. The conversion of $\mathrm{CO}_{2}$ into the fuel can follow two different pathways described in equation (1-2):

- Reverse Water-Gas Shift reaction (RWGS)

$\mathrm{C}^{4+} \mathrm{O}_{2}+\mathrm{H}_{2}^{0}=\mathrm{C}^{2+} \mathrm{O}+\mathrm{H}_{2} \mathrm{O} \quad \Delta \mathrm{H}=41.3 \mathrm{~kJ} / \mathrm{mol} \quad 2 \mathrm{e}^{-}$transfer

- Sabatier reaction (Methanation)

$\mathrm{C}^{4+} \mathrm{O}_{2}+4 \mathrm{H}_{2}^{0}=\mathrm{C}^{4+} \mathrm{H}_{4}+2 \mathrm{H}_{2} \mathrm{O} \quad \Delta \mathrm{H}=-164.7 \mathrm{~kJ} / \mathrm{mol} \quad 8 \mathrm{e}^{-}$transfer

The conversion of the $\mathrm{CO}_{2}$ to $\mathrm{CO}$ via a reverse water gas shift (RWGS) reaction (equation 1) has been widely explored because the produced $\mathrm{CO}$ can be further converted into valuable chemicals and fuels through well-developed synthesis gas $\left(\mathrm{CO}\right.$ and $\left.\mathrm{H}_{2}\right)$ and conversion techniques such as Fischer-Tropsch (FT) and methanol synthesis. The Sabatier reaction or $\mathrm{CO}_{2}$ methanation (equation 2) and methanol formation result in a decreased $\mathrm{CO}$ yield compared to the RWGS reaction. Under atmospheric pressure, the yield of methanol is rather low or absent and this can 
be ignored. However, a strong exothermic methanation reaction is thermodynamically more favoured over the mildly endothermic RWGS reaction at low reaction temperatures; therefore, minimizing the methanation during RWGS becomes a great challenge. $\mathrm{CO}$ may evolve as an intermediate in the hydrogenation of $\mathrm{CO}_{2}$ to $\mathrm{CH}_{4}$ or $\mathrm{CH}_{3} \mathrm{OH}$, and other hydrocarbons fuels[24]. In recent years the most studied $\mathrm{CO}_{2}$ hydrogenation catalysts were nickel-based $\left(\mathrm{Ni} / \mathrm{ZrO}{ }_{2}, \mathrm{Ni}-\mathrm{Ga}\right.$, and $\mathrm{Ni} / \mathrm{CeO}_{2}$ ) [25-28], however, they are low-priced, typically accompanied by several shortcomings, such as their pyrophoricity, low stability, and fast deactivation [29].

\subsubsection{Efficient energy storage devices (supercapacitor)}

It is not an overstatement to say that the success of any renewable energy source (e.g., windmills and solar cells), hybrid and electric vehicles and smart grids depend significantly upon the availability of suitable energy storage systems. As storing and delivering energy at a very fast rate, offering high current in a short duration, a supercapacitor can match the necessity of an efficient renewable energy storage system. Although advanced batteries such as lithium-ion or sodium-ion batteries have undoubtedly high energy density, they also have very low power density and require a large number of electrode materials, which shortens the lifetime and increases the cost of these batteries [30][31]. A solution to this problem could be the supercapacitors, which have higher power density, longer almost limitless cycle time, and superfast charging time compared to traditional capacitors. These characteristic properties of the supercapacitors are shown in Figure $\mathbf{2}$ as it's filling the gap between capacitors and batteries, and even overlapping with both. Also, supercapacitors are light, stretchable, possess flexible designs, and consist of more environmentally friendly composites [32-34].

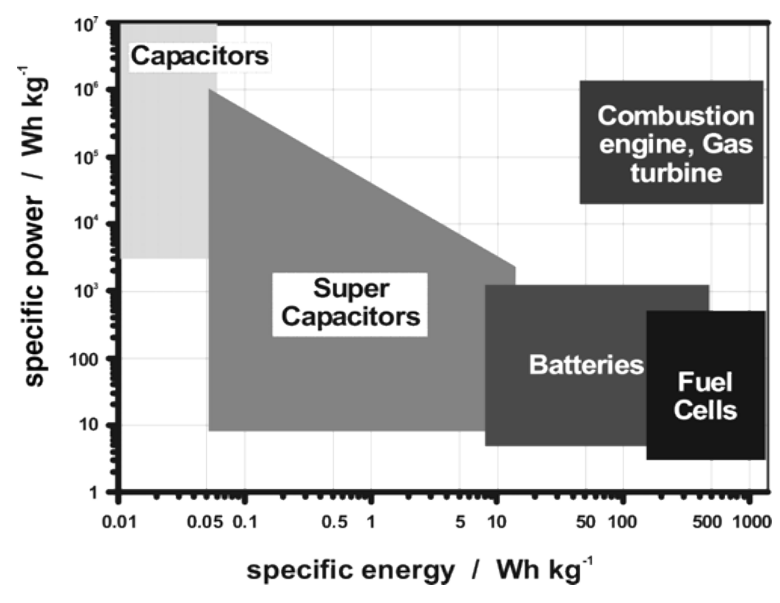

Figure 2. Ragone plot of the energy storage domains for the various electrochemical energy conversion systems compared to an internal combustion engine and turbines and conventional capacitors [35].

We can differentiate two main types of supercapacitors based on the composition: conventional carbon-based EDLCs (electrical double-layer capacitors) and pseudocapacitors (metal oxides based). EDLCs require porous electrode material, they have a high surface area, although they have serious drawbacks, like their tendency to self-discharge and their relatively 
low energy density compared to batteries [36]. Pseudocapacitors, on the other hand, combine the advantages of batteries and EDLCs. Metal oxide $\left(\mathrm{MnO}_{2}, \mathrm{Ru}_{2} \mathrm{O}_{5}, \mathrm{IrO}_{2}\right)$ based pseudocapacitors store energy electrostatically and electrochemically as well, which creates higher power density than EDLCs or batteries [37][38]. While all supercapacitors show high energy and power density, among them manganese oxides are the most promising because of their abundance in nature, they are also environmentally friendly [39].

\subsection{Physico-chemical properties of the manganese and its derivatives}

\subsubsection{Electronic and physical properties}

Atomic manganese contains 25 neutrons, 30 protons and 25 electrons. It has an empirical atomic radius of $140 \mathrm{pm}$ (picometer), a calculated atomic radius of $160 \mathrm{pm}$, and a $245 \mathrm{pm}$ van der Waals radius. Manganese is the $25^{\text {th }}$ element in the chemical periodic table. It is one of the dblock elements and a ground state of an electronic configuration of the manganese is [Ar] $3 \mathrm{~d}^{5} 4 \mathrm{~S}^{2}$. $\mathrm{S}$ orbital shell radius is $141.9 \mathrm{pm}$ but $\mathrm{d}$ orbital shell radius is $40.9 \mathrm{pm}$. This orbital shell radius difference strongly depends on the ionic radius of manganese with different oxidation states. Metallic manganese has a $7.44 \mathrm{~g} / \mathrm{cm}^{3}$ density, its melting point is $1247^{\circ} \mathrm{C}$, and the boiling point is $2061^{\circ} \mathrm{C}$. Metallic manganese exists in four different allotropic modifications such as alpha $(\sigma)$, beta $(\beta)$, gamma $(\gamma)$, and delta phase $(\Delta)$. They occur at temperatures between $25-725^{\circ} \mathrm{C}, 725$ $1095^{\circ} \mathrm{C}, 725-1095^{\circ} \mathrm{C}$, and $1134-1245^{\circ} \mathrm{C}$, respectively. G. Grasselly etc., [40] studied the thermal properties of the manganese oxide of higher valences $\left(\mathrm{Mn}_{3} \mathrm{O}_{4}, \mathrm{Mn}_{2} \mathrm{O}_{3}, \mathrm{MnO}_{2}\right)$, whereas manganese oxides transform into each other, for example, $\mathrm{MnO}_{2}$ changes to $\mathrm{Mn}_{3} \mathrm{O}_{4}$ at 500-600 ${ }^{\circ} \mathrm{C}$, and $\mathrm{Mn}_{3} \mathrm{O}_{4}$ to $\mathrm{Mn}_{2} \mathrm{O}_{3}$ at $600-900{ }^{\circ} \mathrm{C}$, and $\mathrm{Mn}_{2} \mathrm{O}_{3}$ changes to $\mathrm{Mn}_{3} \mathrm{O}_{4}$ at $1050{ }^{\circ} \mathrm{C}$ in an argon atmosphere. The conductivity of manganese oxides is diverse, for example, $\mathrm{MnO}$ is a poor conductor but $\mathrm{MnO}_{2}$ is a good conductor due to its electron configuration.

\subsubsection{Oxidation states and electrochemical properties}

Transition metals as known d-block elements are contained five orbitals in the $\mathrm{d}$ subshell. As the number of unpaired valence electrons in d-orbitals increases, the oxidation state increases. This is because the unpaired valence electrons are unstable and eager to bond with other chemical species. Manganese has the highest number of oxidation states out of all the transition metals due to the presence of the highest number of unpaired valence electrons showed in Figure 3. As mentioned earlier, manganese has a wide variety of oxidation states ranging from -3 to +7 and the most common oxidation states of manganese are $+2,+3,+4,+5,+6$, and +7 . Out of these, the most stable oxidation state is +2 , which has a pale pink colour, and many manganese $(+2)$ compounds are well known such as manganese sulfate $\left(\mathrm{MnSO}_{4}\right)$ and manganese chloride $\left(\mathrm{MnCl}_{2}\right)$. Manganese (+2) most commonly exists with a high spin, $\mathrm{S}=5 / 2$ ground state because 
of the high pairing energy for manganese (II). There is no spin-allowed $\mathrm{d}-\mathrm{d}$ transition in manganese $(+2)$, explaining why manganese $(+2)$ compounds are typically pale to colourless. The +3 -oxidation state occurs in compounds like manganese $(+3)$ acetate, but these are quite powerful oxidizing agents and prone to disproportionation in solutions, forming manganese $(+2)$ and manganese (+4). Solid compounds of manganese $(+3)$ are characterized by their strong purple-red colour and their tendency to form distorted octahedral crystal structure resulting from the Jahn-Teller effect [41]. The oxidation state +5 can be produced by dissolving manganese dioxide in molten sodium nitrite. Permanganate (oxidation state +7 ) compounds are purple and can give a glass a violet colour and they are known as common oxidizers. Because of the wide variety of oxidation states, manganese can create various type of oxides, such as $\mathrm{Mn}_{2} \mathrm{O}, \mathrm{MnO}$, $\mathrm{Mn}_{3} \mathrm{O}_{4}, \mathrm{Mn}_{2} \mathrm{O}_{3}, \mathrm{MnO}_{2}, \mathrm{Mn}_{5} \mathrm{O}_{8}, \mathrm{MnO}_{3}, \mathrm{Mn}_{2} \mathrm{O}_{7}$. These oxides have a different crystal structure, and different physicochemical properties as well. The oxidation state of the manganese can be changed easily with $\mathrm{pH}$ and temperature fluctuations.

\begin{tabular}{|c|c|c|c|c|}
\hline $\begin{array}{c}\text { Element Name } \\
\text { and Symbol }\end{array}$ & \begin{tabular}{|l} 
Atomic \\
Number
\end{tabular} & $\begin{array}{c}\text { Common } \\
\text { Oxidation States }\end{array}$ & \multicolumn{2}{|c|}{ Electron Configuration } \\
\hline Scandium (Sc) & 21 & +3 & Sc: $[\mathrm{Ar}] 4 \mathrm{~s}^{2} 3 \mathrm{~d}^{1}$ & Sc: $[A r] \quad \frac{1}{4 s} \underbrace{1-\ldots-C}_{3 d}$ \\
\hline Titanium (Ti) & 22 & +4 & Ti: $[\mathrm{Ar}] 4 \mathrm{~s}^{2} 3 \mathrm{~d}^{2}$ & Ti: [Ar] $\frac{1}{4 s} 1 \underbrace{1-1}=-$ \\
\hline Vanadium (V) & 23 & $+2,+3,+4,+5$ & $\mathrm{~V}:[\mathrm{Ar}] 4 \mathrm{~s}^{2} 3 \mathrm{~d}^{3}$ & V: $[$ Ar $] \frac{1}{4 s} 1$ \\
\hline $\begin{array}{l}\text { Chromium } \\
\text { (Cr) }\end{array}$ & 24 & $+2,+3,+6$ & $\mathrm{Cr}:[\mathrm{Ar}] 4 \mathrm{~s}^{1} 3 \mathrm{~d}^{5}$ & $C_{r:[A r]} \frac{1}{4 s} \underbrace{11111}_{3 d}$ \\
\hline $\begin{array}{l}\text { Manganese } \\
\text { (Mn) }\end{array}$ & 25 & $+2,+3,+4,+6,+7$ & $\mathrm{Mn}:[\mathrm{Ar}] 4 \mathrm{~s}^{2} 3 \mathrm{~d}^{5}$ & Mn: [Ar] $\frac{1}{4 s} 1 \underbrace{11111}$ \\
\hline Iron $(\mathbf{F e})$ & 26 & $+2,+3$ & $\mathrm{Fe}:[\mathrm{Ar}] 4 \mathrm{~s}^{2} 3 \mathrm{~d}^{6}$ & Fe: $[A r] \frac{1}{4 s} \underbrace{111111}_{3 d}$ \\
\hline Cobalt (Co) & 27 & $+2,+3$ & $\mathrm{Co}:[\mathrm{Ar}] 4 \mathrm{~s}^{2} 3 \mathrm{~d}^{7}$ & $C_{0}:[A r] \frac{1}{4 s} \underbrace{1}_{\text {3d }} \underbrace{1111}_{11} 1$ \\
\hline Nickel (Ni) & 28 & +2 & $\mathrm{Ni}:[\mathrm{Ar}] 4 \mathrm{~s}^{2} 3 \mathrm{~d}^{8}$ & $\mathrm{Ni}:[\mathrm{Ar}] \frac{1}{4 \mathrm{~s}} \underbrace{1} \underbrace{\mathbb{1} 11} \mathbb{1} 1$ \\
\hline Copper $(\mathrm{Cu})$ & 29 & $+1,+2$ & $\mathrm{Cu}:[\mathrm{Ar}] 4 \mathrm{~s}^{1} 3 \mathrm{~d}^{10}$ & Cu: [Ar] $\frac{1}{4 s} \underbrace{\mathbb{1}}_{3 \mathrm{~d}} \underbrace{\mathbb{1}}_{\mathbb{1}} \mathbb{1} \mathbb{1}$ \\
\hline Zinc (Zn) & 30 & +2 & $\mathrm{Zn}:[\mathrm{Ar}] 4 \mathrm{~s}^{2} 3 \mathrm{~d}^{10}$ & $\mathrm{Zn:}[\mathrm{Ar}] \frac{\mathbb{1}}{4 \mathrm{~s}} \underbrace{\mathbb{1}}_{3 \mathrm{~d}} \underbrace{\mathbb{1}}_{\mathbb{1}} \mathbb{1} \mathbb{1}$ \\
\hline
\end{tabular}

Figure 3. Electronic configuration and common oxidation state varieties of d-block elements including $\mathrm{Mn}$ in the middle of the column.

Electrochemistry is the branch of physical chemistry that studies the relationship between electricity, and a chemical change. Electrochemical reactions involve electric charges moving between electrodes and an electrolyte (or ionic species in a solution). Electrochemical processes involve electron transfer to or from a molecule or ion, while also oxidation state change takes place. The electrochemical properties of ionic manganese compounds are strongly dependent on the electrochemical potential and $\mathrm{pH}$. In standard reduction 
potentials, the negative sign of the $\mathrm{E}^{\circ}$ value signifies that it releases electrons more readily than hydrogen does. The positive sign of the $\mathrm{E}^{\circ}$ value, on the other hand, signifies that it releases electrons less readily than hydrogen. The most stable manganese ionic compounds are shown in Figure 4 at different redox(oxidation-reduction) potential (Eh, V) and $\mathrm{pH}$ values [42]. As it can be seen on the diagram, metallic manganese can be stable at any $\mathrm{pH}$ value from 0 to 16 , but under highly reducing conditions, when redox potential is less than -1 (low $\mathrm{Eh}, \mathrm{V}$ ). $\mathrm{Mn}^{2+}$ ions are more stable redox potential ranges between -1 to +1 (average $\mathrm{Eh}, \mathrm{V})$, it is stable in acidic media $(\mathrm{pH}$ 7.5-0). Under highly oxidizing conditions such as 0 to +2.5 (high $\mathrm{Eh}, \mathrm{V}$ ), a higher valences oxide such as $\mathrm{Mn}_{3} \mathrm{O}_{4}, \mathrm{Mn}_{2} \mathrm{O}_{3}, \mathrm{MnO}_{2} \mathrm{MnO}_{4}{ }^{2-}$, and $\mathrm{MnO}_{4}^{-}$ions are stable at a wider range of $\mathrm{pH}$ values, also they are thermodynamically more stable in the alkaline region ( $\mathrm{pH} 7-16)$.

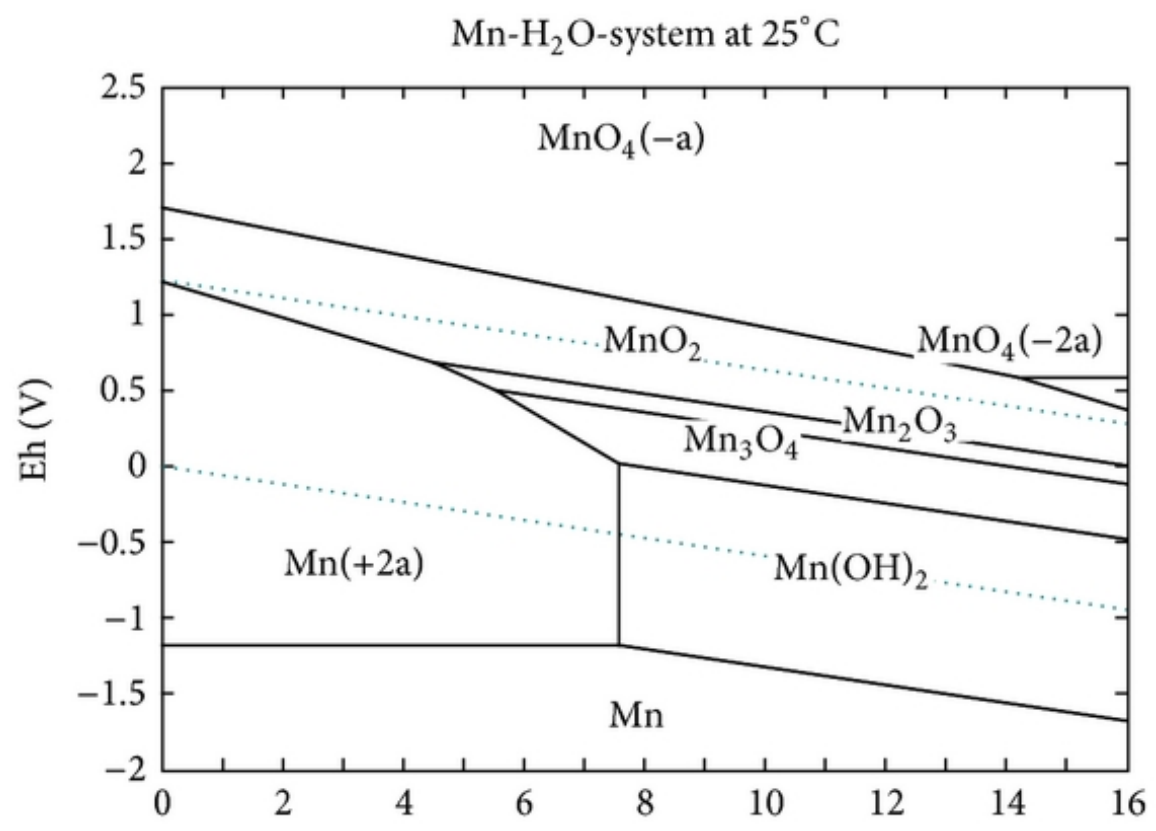

Figure 4. Eh-pH diagram shows the predominant manganese forms and $\mathrm{Mn}-\mathrm{H}_{2} \mathrm{O}$ systems. Temperature, $25^{\circ} \mathrm{C} \pm 0.5[42]$.

A more detailed list of the redox potentials of the common manganese reactions in acidic and basic solution are listed in Table 2 [43]. The oxidizing ability of the manganese agent increases with the oxidation states in nature and for artificial chemicals as well. On the other hand, they can be the stronger reducing agent in a lower oxidation state, like $\mathrm{Mn}^{2+}$ for example. A fine middle ground is the $\mathrm{Mn}^{4+}$, which has reducing and oxidizing capabilities as well. These redox properties play an essential role in numerous manganese dioxide-based material applications 
Table 2. Redox potentials for manganese ions in aqueous solutions.

\begin{tabular}{|c|c|c|}
\hline № & Reaction & $\mathbf{E}^{\circ}(V v s N H E)$ \\
\hline 1 & $\mathrm{MnO}_{4}^{2-}+4 \mathrm{H}^{+}+2 \mathrm{e}^{-}=\mathrm{MnO}_{2(\mathrm{~s})}+2 \mathrm{H}_{2} \mathrm{O}($ acidic $)$ & +2.26 \\
\hline 2 & $\mathrm{Mn}^{3+}+\mathrm{e}^{-}=\mathrm{Mn}^{2+}($ acidic $)$ & +1.54 \\
\hline 3 & $\mathrm{MnO}_{4}^{-}+8 \mathrm{H}^{+}+5 \mathrm{e}^{-}=\mathrm{Mn}^{2+}+4 \mathrm{H}_{2} \mathrm{O}($ acidic $)$ & +1.51 \\
\hline 4 & $\mathrm{MnO}_{2(\mathrm{~s})}+4 \mathrm{H}^{+}+2 \mathrm{e}^{-}=\mathrm{Mn}^{2+}+2 \mathrm{H}_{2} \mathrm{O}($ acidic $)$ & +1.24 \\
\hline 5 & $\mathrm{MnO}_{2(\mathrm{~s})}+4 \mathrm{H}^{+}+\mathrm{e}^{-}=\mathrm{Mn}^{+}+2 \mathrm{H}_{2} \mathrm{O}$ (acidic) & +1.0 \\
\hline 6 & $\mathrm{MnO}_{4}{ }^{3-}+2 \mathrm{H}_{2} \mathrm{O}+\mathrm{e}^{-}=\mathrm{MnO}_{2(\mathrm{~s})}+4 \mathrm{OH}^{-}$(basic) & +0.9 \\
\hline 7 & $\mathrm{MnO}_{4}^{2-}+2 \mathrm{H}_{2} \mathrm{O}+2 \mathrm{e}^{-}=\mathrm{MnO}_{2(\mathrm{~s})}+4 \mathrm{OH}^{-}($basic $)$ & +0.60 \\
\hline 8 & $\mathrm{MnO}_{4}^{-}+2 \mathrm{H}_{2} \mathrm{O}+3 \mathrm{e}^{-}=\mathrm{MnO}_{2(\mathrm{~s})}+4 \mathrm{OH}^{-}($basic $)$ & +0.59 \\
\hline 9 & $\mathrm{MnO}_{4}^{-}+\mathrm{e}^{-}=\mathrm{MnO}_{4}^{2-}($ basic $)$ & +0.56 \\
\hline 10 & $\mathrm{Mn}(\mathrm{OH})_{3(\mathrm{~s})}+\mathrm{e}^{-}=\mathrm{Mn}(\mathrm{OH})_{2(\mathrm{~s})}+\mathrm{OH}^{-}$ & +0.2 \\
\hline 11 & $\mathrm{MnO}_{2(\mathrm{~s})}+2 \mathrm{H}_{2} \mathrm{O}+\mathrm{e}^{-}=\mathrm{Mn}(\mathrm{OH})_{3(\mathrm{~s})}+\mathrm{OH}^{-}($basic $)$ & +0.1 \\
\hline 12 & $\mathrm{Mn}_{2} \mathrm{O}_{3}+\mathrm{e}^{-}=\mathrm{Mn}(\mathrm{OH})_{2}$ (basic) & -0.25 \\
\hline 13 & $\mathrm{Mn}^{2+}(\mathrm{aq})+2 \mathrm{e}^{-}=\mathrm{Mn}(\mathrm{s})($ acidic $)$ & -1.19 \\
\hline 14 & $\mathrm{Mn}^{2+}(\mathrm{aq})+2 \mathrm{e}^{-}=\mathrm{Mn}(\mathrm{s})($ basic $)$ & -1.56 \\
\hline
\end{tabular}

\subsubsection{Crystal structures of the manganese oxides}

As mentioned earlier, $\mathrm{Mn}$ is one of the d-block transition metals and they have a special crystal structure due to forming coordination complexes between metals (such as $\mathrm{Mn}$ ) and ligands (such as O). According to crystal field theory (CFT), an octahedral metal complex forms because of the electrostatic interaction of a positively charged metal ion with six negatively charged ligands or with the negative ends of dipoles associated with the six ligands. In addition, the ligands interact with one another electrostatically. The lowest-energy arrangement of six identical negative charges is an octahedron, which minimizes repulsive interactions between the ligands. The ionic radius of $\mathrm{Mn}$ is smaller than that of $\mathrm{O}^{2-}$, thus, the oxide structures usually show cubic close packing of anions, with the smaller metal cations situated in the octahedral and tetrahedral holes of the oxide network [44]. The Crystal Field Stabilization Energy (CFSE) almost always favours octahedral over tetrahedral crystal structure, but the degree of possibility varies with the electronic configuration. In other words, for $\mathrm{d}^{1}$ there's only a small energy gap between the octal and tetra lines, whereas at $\mathrm{d}^{3}$ and $\mathrm{d}^{8}$ there is a big gap. However, for the $\mathrm{d}^{0}, \mathrm{~d}^{5}$ high spin and $\mathrm{d}^{10}$, there is no CFSE difference between octahedral and tetrahedral. The order of favorability of octahedral over tetrahedral is: $\mathrm{d}^{3}, \mathrm{~d}^{8}>\mathrm{d}^{4}, \mathrm{~d}^{9}>\mathrm{d}^{2}, \mathrm{~d}^{7}>\mathrm{d}^{1}, \mathrm{~d}^{6}>\mathrm{d}^{0}, \mathrm{~d}^{5}, \mathrm{~d}^{10}$. According to this order, $\mathrm{d}^{3}$ electronic configuration $\mathrm{Mn}^{4+}$ tends to form octahedral crystal structure unit cell, while the oxidation state variants mostly form tetrahedral structure over octahedral. 


\section{Manganese (IV) oxide polymorphs:}

According to CFT, $\mathrm{MnO}_{2}$ tends to form an octahedral unit cell structure. This $\left[\mathrm{MnO}_{6}\right]$ octahedral unit cell builds up manganese dioxide polymorphs: $\alpha-\mathrm{MnO}_{2}, \beta-\mathrm{MnO}_{2}, \gamma-\mathrm{MnO}_{2}, \delta$ $\mathrm{MnO}_{2}$, and $\lambda-\mathrm{MnO}_{2}$ shown in Figure 5. The piling up of $\mathrm{MnO}_{6}$ octahedra builds one-, two- or three-dimensional tunnel structures. Different structures can be described by the size of their tunnels, which are determined by the number of octahedral subunits $(n \times m)$. For the $\alpha$ $\mathrm{MnO}_{2}$ structure, the double chains of edge-sharing $\mathrm{MnO}_{6}$ octahedra share corners and form onedimensional square $2 \times 2$ open tunnels but $\beta-\mathrm{MnO}_{2}$ has $1 \times 1$ tunnel formed by a single strand of edge-sharing $\mathrm{MnO}_{6}$ octahedra. Consequently, the $\beta$-type structure is the most stable phase of $\mathrm{MnO}_{2} \cdot \gamma-\mathrm{MnO}_{2}$ possesses varying structures and compositions, with a disorder intergrowth of ramsdellite $(1 \times 2$ tunnels $)$ and pyrolusite $(1 \times 1$ tunnel $) . \delta-\mathrm{MnO}_{2}$ is a two-dimensional layered birnessite structure with an interlayer separation. This unique two-dimensional structure is characterized by the distance between layers, which depends on the cations and $\mathrm{H}_{2} \mathrm{O} . \lambda-\mathrm{MnO}_{2}$ is one of the metastable forms of manganese dioxide, which transforms into the thermodynamically stable $\beta-\mathrm{MnO}_{2}$ or pyrolusite with the rutile structure.

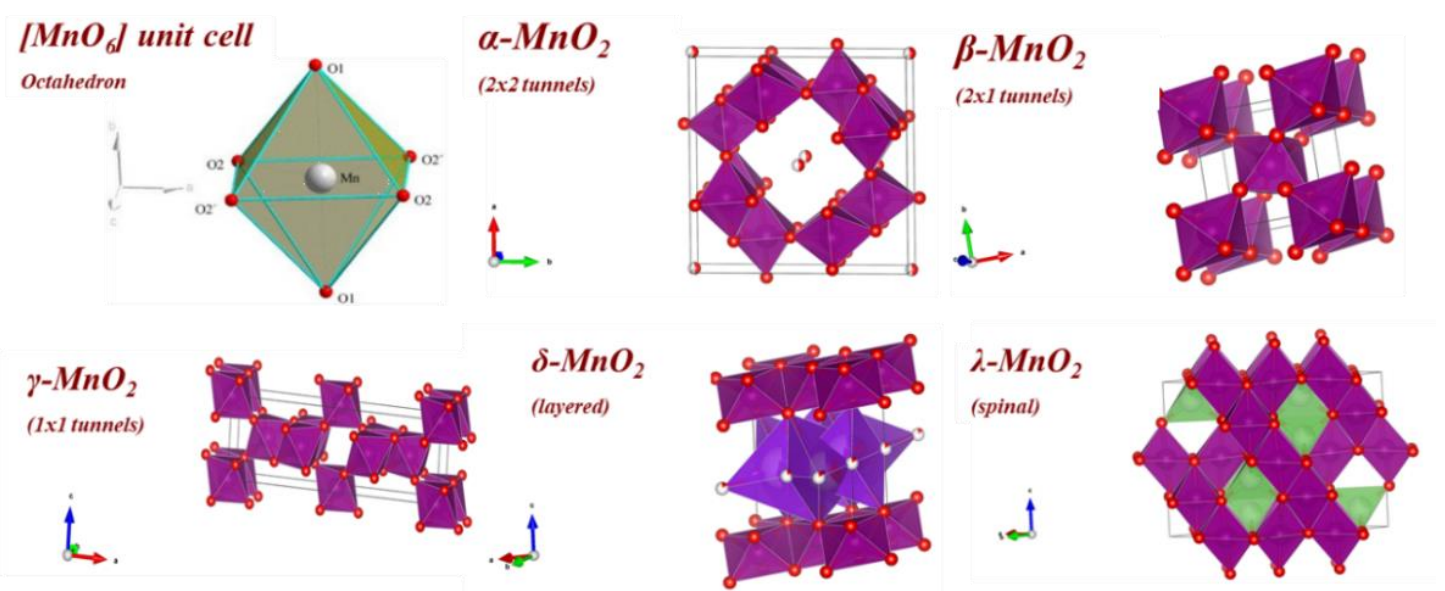

Figure 5. The octahedral unit cell and crystal structure of the polymorphs of the manganese dioxides illustrated by the VESTA visualization program using data from the Crystallography Open Database.

\section{Birnessite-type delta manganese dioxide:}

From these polymorphs shown in Figure 5, delta( $(\delta)$-manganese oxide, also known as birnessite, is one of the most common manganese minerals in nature, which was first described in 1956 [45]. It has a layered structure with the following constitution: $\left(\mathrm{Na}_{0.3} \mathrm{Ca}_{0.1} \mathrm{~K}_{0.1}\right)\left(\mathrm{Mn}^{4+}\right.$, $\left.\mathrm{Mn}^{3+}\right)_{2} \mathrm{O}_{4} \cdot 1.5 \mathrm{H}_{2} \mathrm{O}$ ). As a consequence of layered structure and earth-abundance, an increasing number of studies have investigated birnessite as a water oxidation catalyst [46] and the supercapacitor [47]. Birnessite-type of layered manganese oxides is mostly found in finely ordered or poorly crystallized forms. Natural and synthetic birnessite phases are both defined by 
interlayer molecules such as water and cations $\left(\mathrm{K}^{+}, \mathrm{Na}^{+}, \mathrm{Ca}^{2+}, \mathrm{Mg}^{2+}\right)$, the distances between manganese octahedral layers, and the ratio of manganese oxidation states. Due to the number and position of interlayer molecules, vacancies, and oxidation state differences, birnessite can be found in several crystal structures such as monoclinic, triclinic, trigonal, orthogonal, and hexagonal [48]. The difference in the average number of the oxidation state of the manganese also plays an important role in the crystal structure, creating vacancies as shown in Figure 6. The above-mentioned differences play an essential role in the electrochemical properties of birnessite. Numerous studies have reported the effect of the interlayer cation exchanges, and the number of water molecules on the catalytic activity for water oxidation [30] and oxygen evaluation reaction [31].

\section{Triclinic Na-birnessite}

Hexagonal $\mathrm{H}$-birnessite

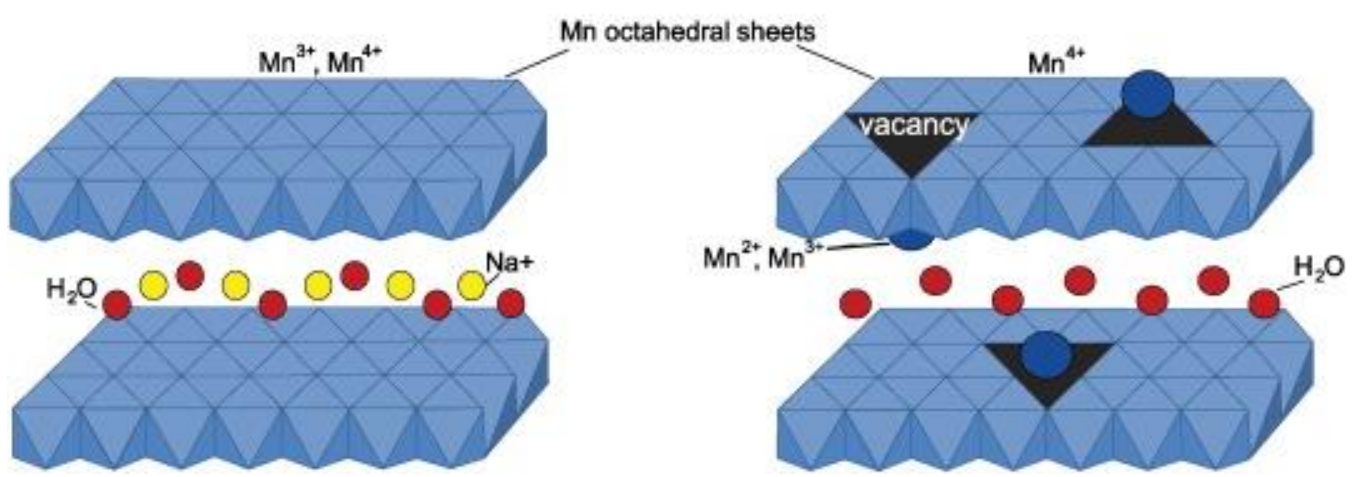

Figure 6. Schematic diagram of (a) triclinic Na-birnessite and (b) hexagonal H-birnessite [51].

\section{Hausmannite type manganese oxide (III, II):}

Hausmannite type manganese oxide $\left(\mathrm{Mn}_{3} \mathrm{O}_{4}\right.$ it's a mixture of $\mathrm{Mn}_{2} \mathrm{O}_{3}$ and $\left.\mathrm{MnO}\right)$ has distorted crystal structures. It can be easily produced from manganese (II)oxide $(\mathrm{Mn}+2)$, from hydroxides in the air or by removing interlayer molecules of birnessite type of oxides. The average oxidation state of manganese in the hausmannite phase is about +2.5 because it contains +3 and +2 equally as shown in Figure 7a-b. Due to the lower oxidation state, octahedral $\mathrm{Mn}^{3+}$ and tetrahedral $\mathrm{Mn}^{2+}$ form together with a close-packed and distorted crystal structure.

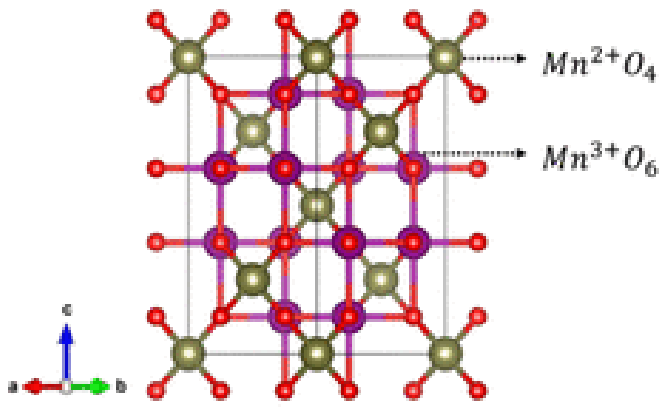

(a)

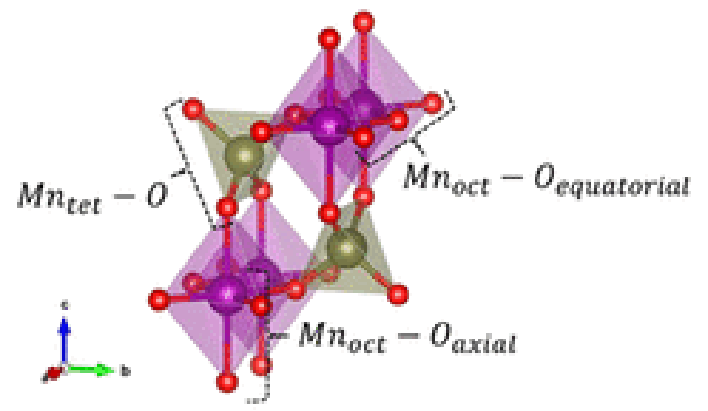

(b)

Figure 7. Hausmannite cell unit with 28 atoms (a) $\mathrm{Mn}^{2+}$ tetrahedral and $\mathrm{Mn}^{3+}$ octahedral sites and (b) the detailed structure of the different $\mathrm{Mn}$ sites [52]. 


\subsection{Natural occurrence and synthesis methods}

\subsubsection{Natural origin and occurrence}

Manganese is the second most abundant transition metal in the Earth's crust after iron. Its concentration in the Earth's crust reaches as much as 0.098 mass \%. An average of $1100 \mathrm{ppm}$ (part per million) $\mathrm{Mn}$ is contained in igneous rock, shale, and limestone which is a common rock in the Earth's crust [53]. The concentration of manganese in the ocean crust is about $60 \%$ greater than that in the continental one [54]. Even on Mars's surface, Mars rovers discovered higher oxidation state manganese oxides, which illustrated that Mars's atmosphere was once oxygenrich and water was present like on Earth [55]. By composition, manganese rocks in Earth's crust can be separated into two chemical and biochemical subgroups: carbonate and oxide (manganolites). Because of the variety of oxidation states, there are about 190 manganese minerals known with $\mathrm{Mn}$ contents $25 \%$ or greater. Among these, about 30 predominantly the oxides, hydroxides, and carbonates - dominate the phases in commercial ores. The natural origin and the typical occurrence of these minerals are displayed in Figure 8. The predominant oxides and hydroxides minerals of manganese can be separated into two groups:

1. High valence manganese: modification: pyrolusite, ramsdellite; the group of nsutite $M-n$ $\mathrm{M}_{1 \text { n }} \mathrm{O} \mathrm{OH}_{4}{ }^{2-}$; the group ( $\left.\mathrm{Ba}, \mathrm{Na}, \mathrm{K}, \mathrm{Pb}\right) \mathrm{Mn}_{8} \mathrm{O}_{16} \cdot \mathrm{xH}_{2} \mathrm{O}$ (hollandite, coronadite, cryptomelane, and manjiroite); psilomelane (or romanechite) $\left[(\mathrm{Ba}, \mathrm{K}, \mathrm{Mn}, \mathrm{Co})_{2} \mathrm{Mn}_{5} \mathrm{O}_{10} \cdot \mathrm{xH}_{2} \mathrm{O}\right]$; the group of birnessite $(\mathrm{Ca}, \mathrm{Na})\left(\mathrm{Mn}^{2+}, \mathrm{Mn}^{4+}\right)_{7} \mathrm{O}_{14} \cdot 3 \mathrm{H}_{2} \mathrm{O}$; todorokite $\left(\mathrm{Na}, \mathrm{Ca}, \mathrm{K}, \mathrm{Mn}^{2+}\right)\left(\mathrm{Mn}^{4+}, \mathrm{Mn}^{2+}\right.$, $\mathrm{Mg})_{6} \mathrm{O}_{12} \cdot 3 \mathrm{H}_{2} \mathrm{O}$; ranciéite $\left(\mathrm{Ca}, \mathrm{Mn}^{2+}\right) \mathrm{Mn}_{4}{ }^{4+} \cdot \mathrm{nH}_{2} \mathrm{O}$, and the group of hydroxides of manganese$\mathrm{MnOOH}$ (groutite, feitknechtite, manganite, crednerite, quenselite, and janggunite);

2. Lower valence manganese: braunite $3 \mathrm{Mn}_{2} \mathrm{O}_{3} \cdot \mathrm{MnSiO}_{3}$; and bixbyite $(\mathrm{Mn}, \mathrm{Fe})_{2} \mathrm{O}_{3}$; and 3 . minerals of the isomorphic system $\mathrm{Fe}_{3} \mathrm{O}_{4}-\mathrm{Mn}_{3} \mathrm{O}_{4}$ : jacobsite, hausmannite, and vredenburgite [56]. 


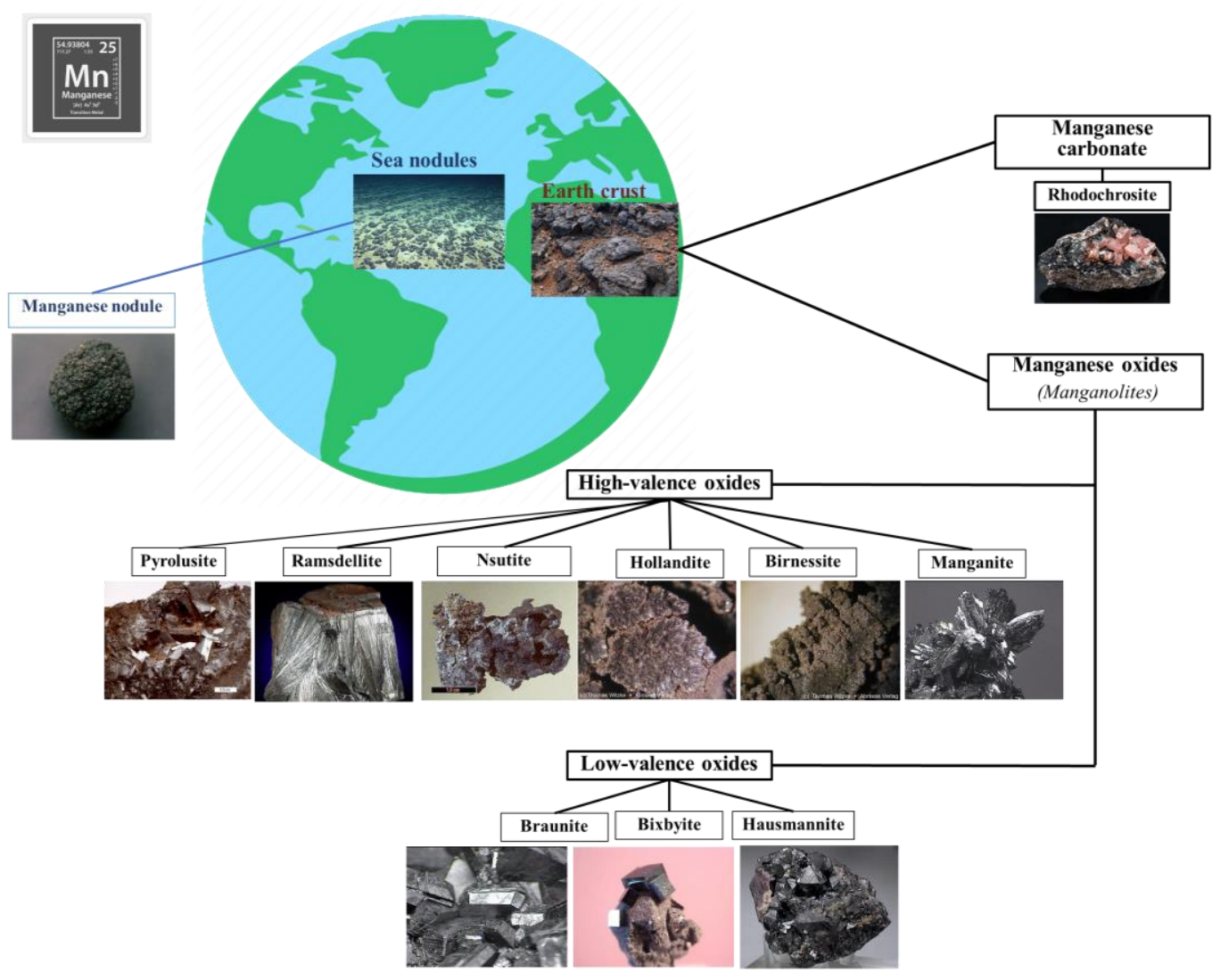

Figure 8. Manganese occurrence (Earth crust and ocean nodules) and typical minerals (mineral photos from [57]) in sedimental rock.

Hungary has several manganese deposits, most of these have ores with a sedimentary origin. The two most important deposits are at Úrkút and Eplény, both in the Bakony Mountains of western Hungary. The primary ore in these deposits is of the late Liassic age. Two types of ore are recognized: manganese oxides and manganese carbonate [58]. All these deposits originate from decomposition - sediment; they can be further classified as follows: local sedimentation like the mineral of Rudabánya and Komlóska, an oxidized zone chemical sedimentation separated from seawater like in Úrkút and Eplény. Other than the places mentioned above, manganese appears in traces at numerous other places [59]. The manganese deposits of Úrkút lie in the Southern Bakony range of the Central Mountains of Transdanubia, which extend to the north to the Balaton Highlands as the local map depicts in Figure 9. The Eplény deposits, on the other hand, lie in Northern Bakony [58]. The mining at Úrkút was responsible for a big portion of Hungarian manganese production, which mainly contains manganese carbonate minerals and a minor amount of pyrolusite/cryptomelane [60]. 


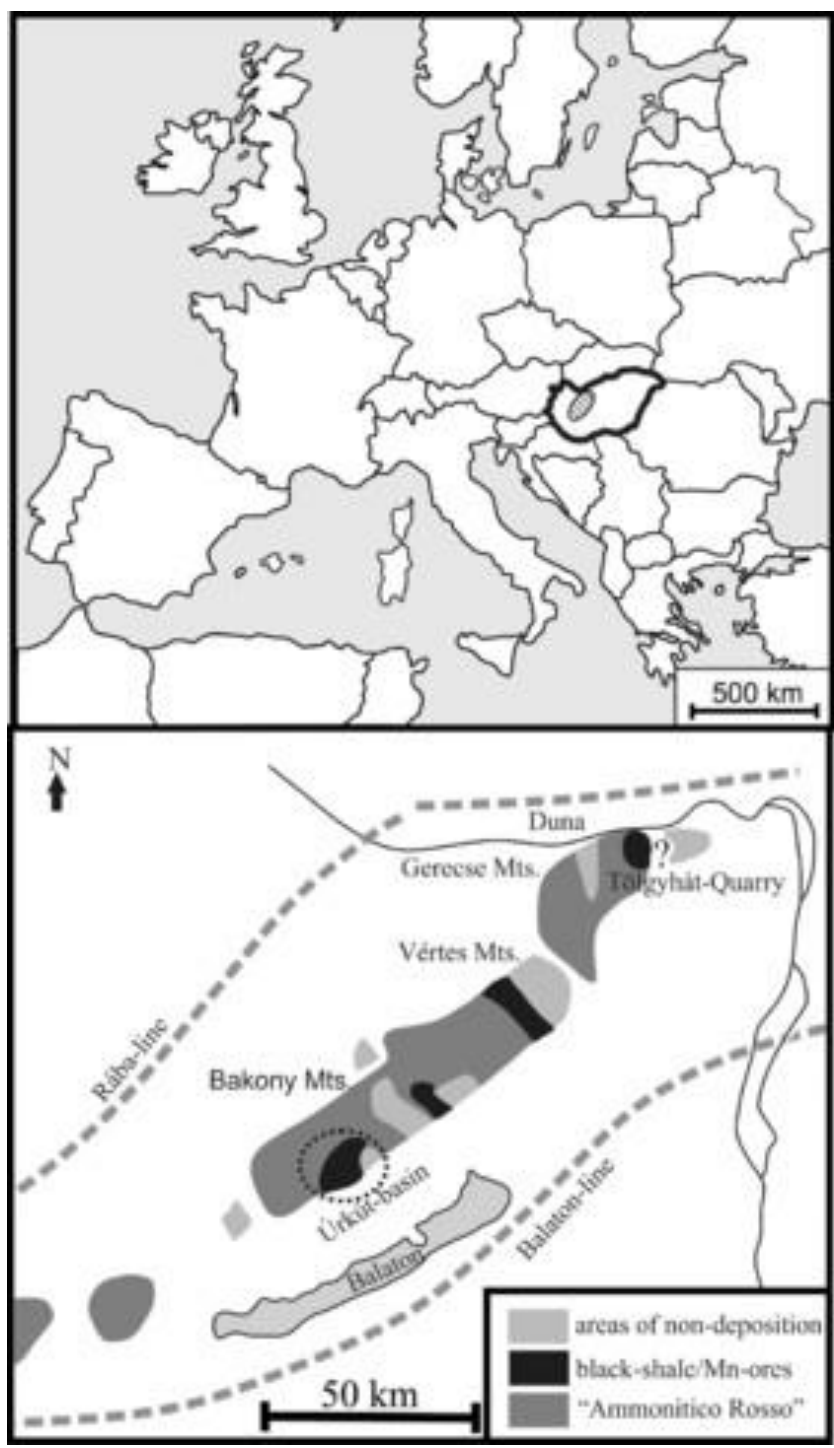

Figure 9. Location of the Úrkút manganese ore deposit.

\subsubsection{The synthesis methods}

\subsubsection{Redox reaction in aqueous media}

Manganese can be oxidized or reduced both depending on the acidic or basic condition and oxidation state, which makes the synthesis of manganese materials more interesting or complex. For example, $\mathrm{MnO}_{4}^{-}$permanganate ion is one of the most powerful oxidizing agents, it can be used for the synthesis of Mn (II) compounds and it's reduced to $\mathrm{Mn}^{2+}$ with a standard reduction potential $\left(\mathrm{E}^{\circ} / \mathrm{V}\right)$ of $+1.49 \mathrm{~V}$ in acidic condition, which is shown in equation (3). In contrast, $\mathrm{Mn}^{2+}$ ion is a powerful reducing agent in basic condition, which requires oxygen and forms manganese dioxide with $-0.05\left(\mathrm{E}^{\circ} / \mathrm{V}\right)$ as shown in equation (4).

$$
\begin{aligned}
& \mathrm{MnO}_{4}^{-}+8 \mathrm{H}^{+}+5 \mathrm{e}^{-}=\mathrm{Mn}^{2+}+4 \mathrm{H}_{2} \mathrm{O} \\
& \mathrm{Mn}^{2+}+\mathrm{O}_{2}+2 \mathrm{OH}^{-}=\mathrm{Mn}^{4+} \mathrm{O}_{2}+2 \mathrm{e}^{-}+\mathrm{H}_{2} \mathrm{O}
\end{aligned}
$$


The more detailed common synthesis routines [61] for manganese dioxide polymorphs $(\alpha, \beta, \gamma, \delta, \lambda)$ and of various manganese oxides $\left(\mathrm{MnO}, \mathrm{Mn}(\mathrm{OH})_{2}, \mathrm{Mn}_{2} \mathrm{O}_{3}, \mathrm{Mn}_{3} \mathrm{O}_{4}\right.$, and $\left.\mathrm{Mn}(\mathrm{OOH})\right)$ are depicted in Figure 10. As shown in the synthetic scheme, $\mathrm{Mn}\left(\mathrm{NO}_{3}\right)_{2}$ is one of two precursors and it's oxidizing in reducing condition $(\mathrm{NaOH})$ or heating and converting into various manganese oxides. Another way around, $\mathrm{KMnO}_{4}$ is reducing in oxidizing condition (acid), converted into other types of manganese oxides.

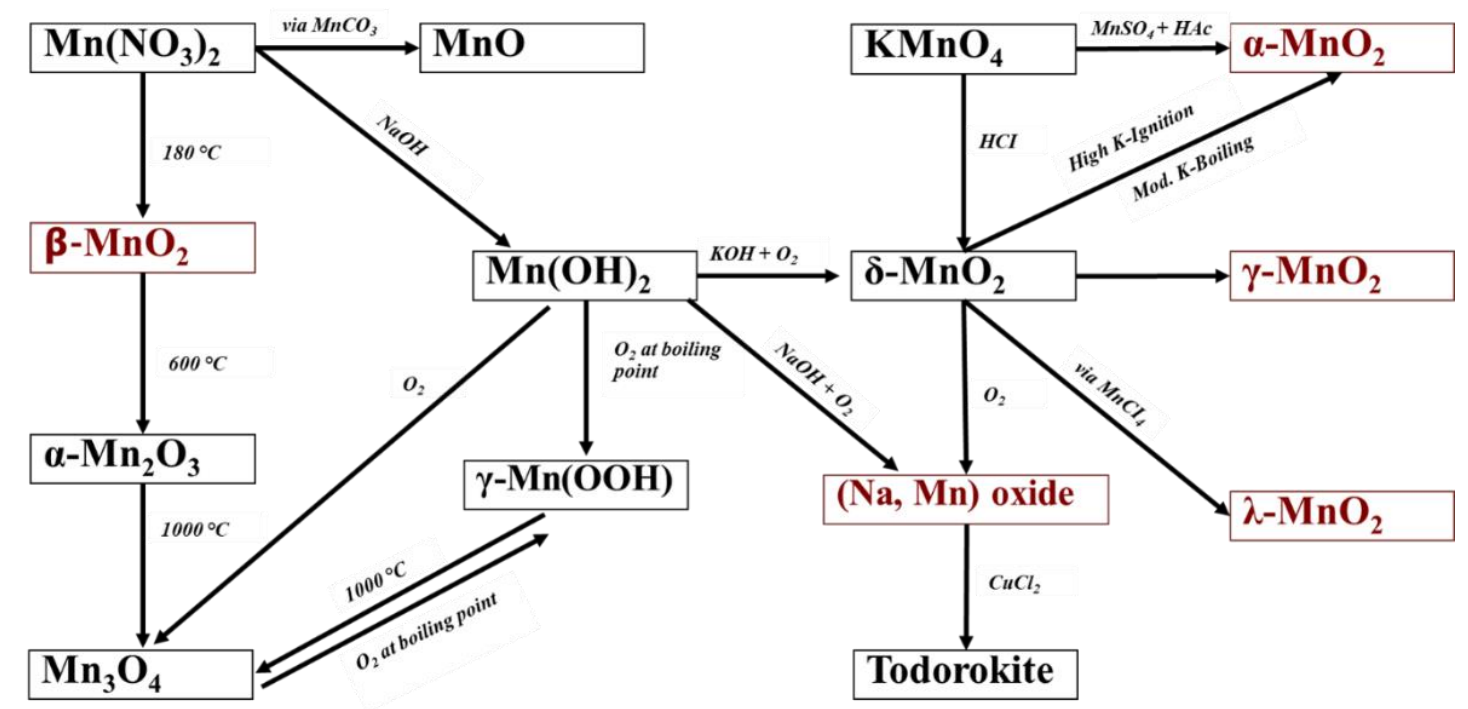

Figure 10. Synthesis routes between various manganese oxides [61].

\subsubsection{Electrolytic deposition}

An electrolytic deposition is a type of synthesis for various types of manganese oxidebased materials. Particularly, it is used to produce electrolytic manganese dioxides (EMD). Electrodeposition of manganese dioxide has been strongly influenced by various factors such as the electrolyte, current density (CD), types of electrodes (anode and cathode), type of the electrochemical cell, the temperature of the electrolyte, type of current (direct current or pulse current) and the $\mathrm{pH}$ of the electrolyte [62]. The electrodeposition process involves electron transfer and phase change and it can be classified into two types: anodic or cathodic electrodeposition based on the reaction mechanism. The manganese oxide electrodeposition method most efficiently deposits catalyst layers on various types of conductive substrates such as indium thin oxide (ITO), metals (Pt, Ni), carbon-based materials (carbon cloth, carbon paper), and polymer (PET, PPy). In an anodic deposition, negatively charged anions react with the positively charged hydrogen ions (protons) which are being produced at the anode by the electrolysis of water to form the original acid. The fully protonated acid carries no charge and is less soluble in water, and may precipitate out of the water onto the anode. In a cathodic deposition, a similar situation occurs except that the material being deposited will have hydroxide 
as the charge-bearing group. If the hydroxide has been formed by protonation of the base, the protonated base will react with the hydroxyl ions being formed by electrolysis of water to yield the neutral charged base and water. Shalini et al. [63] studied the kinetics and mechanism of electrodeposition of manganese dioxide from $\mathrm{Mn}^{2+}$ precursor, suggesting that it involves diffusion of $\mathrm{Mn}^{2+}$ ions to the electrode surface, the oxidation of $\mathrm{Mn}^{2+}$ surface to $\mathrm{Mn}^{3+}$ ads and the oxidation of $\mathrm{H}_{2} \mathrm{O}$ to $\mathrm{OH}_{\text {ads }} \mathrm{Mn}^{3+}{ }_{\text {ads }}$ ions dissociate disproportionately into $\mathrm{Mn}^{2+}{ }_{\text {ads }}$ and $\mathrm{Mn}^{4+}$ ads ions at the electrode surface. These $\mathrm{Mn}^{2+}{ }_{\text {ads }}$ and $\mathrm{Mn}^{4+}{ }_{\text {ads }}$ ions react with $\mathrm{OH}_{\text {ads }}$ and $\mathrm{H}_{2} \mathrm{O}$, respectively, in chemical steps leading to the formation of $\mathrm{MnO}_{2}$.

\subsubsection{Electrophoretic deposition}

In the case of electrophoretic deposition (EDP), the colloidal particles suspended in a liquid medium migrate under the influence of an electric field (electrophoresis) and are deposited onto an electrode. A characteristic mechanism of EDP consists of 4 steps is showed in Figure 11. As it can be seen in Figure 11, (a) colloidal particles are well dispersed and able to move freely and independently in solvent suspension, (b) electrochemical equilibrium of the solvent is responsible for the particles' surface charge, (c) particles move electrophoretically in the bulk of the suspension to the oppositely charged electrode (substrate), and (d) the substrate is covered by a neutralized, firmly deposited layer of particles [64]. Also, some sets of parameters govern the EDP such as particle size, dielectric constant, conductivity, viscosity, zeta potential, stability, the particle concentration of the suspension, applied electric field, deposition time, immersed electrodes surface area, wettability of the electrode, and distance between the electrode pair.

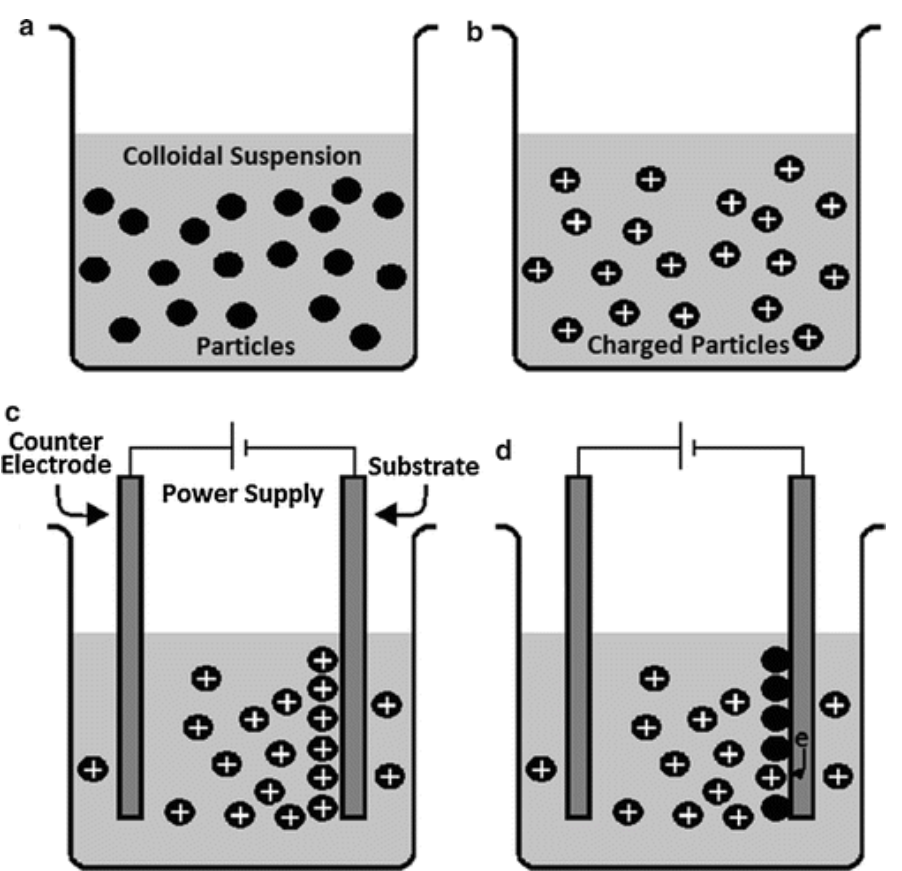

Figure 11. Four steps of EPD; (a) dispersion, (b) electrochemical charging, (c) electrophoresis and (d) deposition[64]. 
The EDP has a wide range of application, a rapid processing time, and require modest equipment. It is a cost-effective method to produce high quality, specific shaped nanostructure and simple to control the thickness and morphology of the deposited materials. However, it has rarely used for manganese-based material synthesis [65][66].

\subsubsection{Mechanochemical ball milling method}

Mechanical ball milling processes are carried out by employing mechanical activation in high energetic apparatus (Figure 12). Depending on the products' chemical and physical properties, quality, and demands, a different type of milling technique is used such as a vibratorycentrifugal mill, ring roll mill, and planetary mill. The planetary ball mill is a high-energy mill primarily used for energy-intensive processes like mechanical alloying, mechanical activation of mechanochemistry [67]. The mechanochemical method is a combination of the mechanical milling and chemical process. Mechanochemistry is more efficient and advanced than the conventional chemical and mechanical methods since physical and chemical energies are added in one reaction, which increases productivity. Mechanochemical synthesis is suitable for large scale production of a variety of nanomaterials and catalysts [68-72], but the research describing mechanochemical manganese oxides synthesis is scarce [73-76]. Mechanochemical synthesis can be tuned by lots of parameters, such as the milling rotation speed, the milling time, the solventtemplate, weight ratios of the milling mixtures and milling balls, the milling atmosphere, the type of the mills, and additional treatments like sonication or heat treatments as well [77-82]. Due to significant drawbacks of conventional dry milling method such as the materials having wider size distribution and material loss, nowadays wet milling methods are more often used for nanomaterial synthesis [83-86]. Besides, energy can be calculated and mapped for wet milling. This is important when the different catalytic activities of each sample are compared since it allows for the preparation of more favourable catalysts.

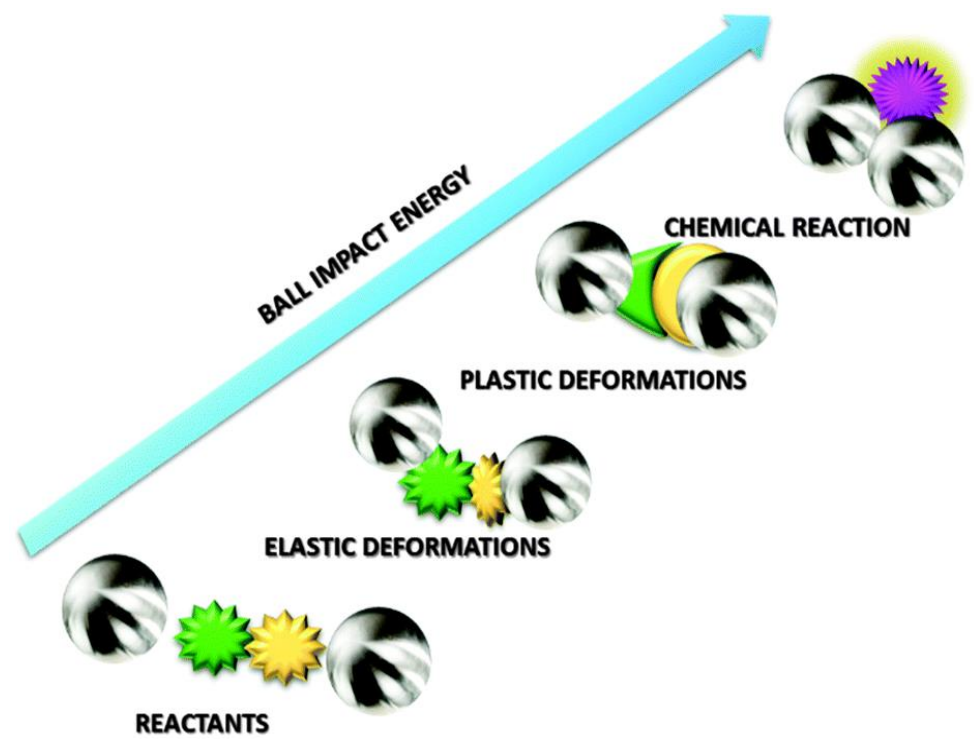

Figure 12. The illustration of a chemical reaction during the mechanical ball milling process [68]. 


\subsubsection{Synthesis from the natural mineral}

Mineral manganese ores are processed by a combination of both mechanical and chemical procedures. Here is the order of mineral processing to produce electrolytic metallic manganese (EMM):

- Crushing or milling

- Reducing the milled ore at various reducing conditions at different temperature ranges (to make it possible to dissolve)

- Leaching of the reduced ore with different solvents (mostly acids)

- Deposition from the acid leached solutions using electrolytic methods.

- Collecting the deposited metal manganese

A current is passed from an inert anode through a liquid leached solution containing the metal so that the metal is extracted as it is deposited during the electroplating process onto the cathode. Electrowinning is a process that produces EMM from the aqueous solution $\left(\mathrm{Mn}^{2+}\right)$, which is the reduced manganese oxide mineral dissolved (mostly leached in acid) [87][88]. Electrowinning of mineral manganese is an alternative to pretreatments such as leaching, removal of impurities, annealing, and dissolution. Electrowinning from the cathodic material of used battery (waste) is a new environmentally friendly process, which is becoming more and more popular [89][90]. The two competing electrolytic reactions on the cathode in the electrowinning process are described in equation (5-6) and equation (7-8) for the anode.

\section{- Cathode:}

$$
\begin{array}{ll}
\mathrm{Mn}^{2+}+2 \mathrm{e}^{-} \rightarrow \mathrm{Mn} & E^{\circ}=-1.18 \mathrm{~V} \\
2 \mathrm{H}_{2} \mathrm{O}+2 \mathrm{e}-\rightarrow \mathrm{H}_{2} \uparrow+2 \mathrm{OH}^{-} & E^{\circ}=0.00 \mathrm{~V}
\end{array}
$$

\section{- Anode:}

$$
\begin{array}{ll}
2 \mathrm{H}_{2} \mathrm{O} \rightarrow \mathrm{O}_{2} \uparrow+4 \mathrm{H}^{+}+4 \mathrm{e}- & E^{\circ}=1.22 \mathrm{~V} \\
\mathrm{Mn}^{2+}+2 \mathrm{H}_{2} \mathrm{O} \rightarrow \mathrm{MnO}_{2}+4 \mathrm{H}^{+}+2 \mathrm{e}^{-} & E^{\circ}=1.22 \mathrm{~V}
\end{array}
$$

As manganese dioxide ores are stable in acid or alkaline oxidizing conditions, the extraction of manganese must be carried out in reducing conditions. In aqueous reduction, $\mathrm{SO}_{2}$, $\mathrm{FeSO}_{4}$, sucrose, charcoal, coal and lignite, pyrite, oxalic acid, etc. can be used as reducing agents. Leaching of manganese ore using oxalic acid-producing microorganisms has also been reported [91], which gives us an insight into bioleaching. The dissolution of manganese is due to the reduction of its dioxide by oxalic acid. The reduction between $\mathrm{MnO}_{2}$ and oxalic acid in the acid medium may be given as follows equation (9).

$$
\mathrm{MnO}_{2}+\mathrm{HOOC}-\mathrm{COOH}+2 \mathrm{H}^{+}=\mathrm{Mn}^{2+}+2 \mathrm{CO}_{2}+2 \mathrm{H}_{2} \mathrm{O}
$$

Some study revealed that the combination of roasting and leaching provides a higher yield and decreases harmful side products [92]. 


\subsection{Applications of the manganese oxides}

\subsubsection{Production of the manganese and general applications}

In 2017, 20 million metric tons of manganese ore were mined [93] globally. The Mn content of ores in the world varies between $20 \%$ and $60 \%$, however, a significant proportion of these resources belong to the low and medium-grade (Mn: 20-35\%; Mn/Fe <2.5) categories. According to a study, the manganese ore price was about 1600 USD/ton in 2008 [94] and the market price for steel was equally strong historically because the manganese market depends on steel market trends.

Manganese minerals participate in the geochemical redox reaction process, remove heavy metals such as $\mathrm{Pb}, \mathrm{As}$, and $\mathrm{Cr}$ from contaminated soil, and play an important role in the biological respiration process and the nutritional circle as well. Even from ancient time, manganese minerals were used as pigments, such as the pyrolusite $\mathrm{Mn}^{4+} \mathrm{O}_{2}$ (tetragonal) and cryptomelane $\mathrm{K}\left(\mathrm{Mn}^{4+}{ }_{7} \mathrm{Mn}^{3+}\right) \mathrm{O}_{16}$, which were found during archaeological excavations [95]. Approximately 80$90 \%$ of the current world production of $\mathrm{Mn}$ ore is consumed by the steel industry; on average, steel contains about 0.6 weight percent Mn but maybe $10 \%$ or more in high-strength steels as described in Figure 13. In particular, manganese is added to the steel production to remove oxygen and sulfur when iron ore (an iron and oxygen compound) is converted into steel [96]. There are other industrial uses, such as the production of special Al alloys, Mn chemicals, catalysts, ion sieve materials for heavy metal removal, water-purifying agents, additives to livestock feed, plant fertilizers, colorant for bricks, adsorbent, and an electrical energy storage device (battery, supercapacitor). About 1.5-10.0\% of the weight of manganese are employed as master alloys for the preparation of manganese-containing aluminum alloys. These alloys are widely used for the cooking of utensils, as well as for base material for beverage cans [97]. Besides, high specific surface area manganese oxide-based materials with a unique crystal structure are used for heavy metal removal and water purification applications.
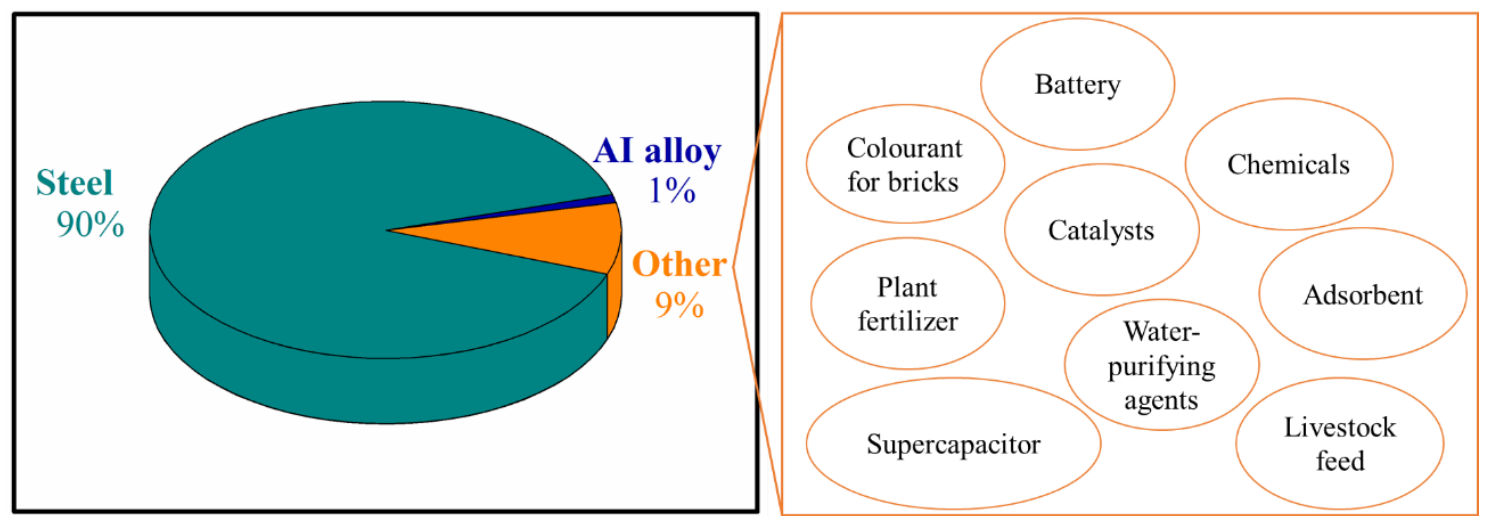

Figure 13. Manganese applications by weight percentage and list of other applications not related to metal production. 
If we emphasize the application of manganese as the catalyst, manganese is much cheaper than commercial noble metal ones. More detail is presented about the catalytic application of manganese in the $\mathrm{ORR}, \mathrm{CO}_{2}$ hydrogenation processes in chapter 2.4.2.1 -2.4.2.2. Another intriguing application for manganese, particularly for manganese dioxide is electrical energy storage devices including various types of batteries and supercapacitors. Due to high activity in electrochemical reactions or processes, manganese dioxides electrode can increase the power density and energy density of batteries and supercapacitors. More detailed information is presented in chapter 2.4.3. In 2020, the market price of manganese compared with the most common noble metals catalysts for ORR, such as $\mathrm{Pt}$, Ir, and Ru, and battery/supercapacitor metals (Li) is displayed in Table 3 [98].

Table 3. The price of the metals in the market (USD per kilogram).

\begin{tabular}{ll}
\hline Metals & Prices, USD/kg \\
\hline $\mathrm{Pt}$ & 35735.7 \\
$\mathrm{Ir}$ & 59965.7 \\
$\mathrm{Ru}$ & 9876.7 \\
$\mathrm{Li}$ & 70.5 \\
$\mathrm{Mn}$ & 0.4 \\
\hline
\end{tabular}

\subsubsection{Manganese oxides catalysts}

Catalysis is a phenomenon by which chemical reactions are accelerated by small quantities of foreign substances, called catalysts [99]. The phenomenon of catalysis was first recognized by Berzelius in 1835 [100]. Since the first recognition of the catalytic reaction, there are studies and descriptions of the catalytic system continuously developing. Because most industrial chemical processes are catalytic, the importance and economic significance of catalysis are enormous. More than $80 \%$ of the present industrial processes established since 1980 in the chemical, petrochemical, and biochemical industries, as well as in the production of polymers and environmental protection, use catalysts. Depending on the physical phase, catalysts are divided into two main categories: homogenous and heterogeneous catalysts. The homogenous catalyst has a common physical phase with reactants or their solution. Manganese metal salts of organic acids and organometallic complexes are known as a homogenous catalyst in various synthesis and processes [101]. Manganese heterojunction catalysts are the manganese combined with other metal oxides as the dopant material or they can be the main component [102]. Manganese oxides have interesting electrochemical properties, which is the main reason to develop manganese catalyst materials for various catalytic reactions. Here I emphasize the manganese oxide catalysts' two different catalytic reactions: 
- Oxygen reduction reaction (see details in the following chapter 2.4.2.1)

- $\mathrm{CO}_{2}$ hydrogenation (see details in the following chapter 2.4.2.2).

\subsubsection{Manganese oxide catalyst for ORR}

In the fuel cell at the cathodic side, an oxygen reduction reaction occurs but it has slow reaction kinetics [103], which can be boosted by catalysts. Manganese oxide-based materials are increasingly studied as the ORR catalyst, for instance, $\mathrm{MnO}_{\mathrm{x}}[104,105], \mathrm{Ag} / \mathrm{MnO}_{\mathrm{x}}$ [106], $\mathrm{NiOx}-$ $\mathrm{MnO}_{\mathrm{x}}$-graphene [107], $\mathrm{Mn}_{3} \mathrm{O}_{4}$ decorated $\mathrm{N}$-doped carbon [108], and porous $\mathrm{Mn}_{2} \mathrm{O}_{3}$ [109]. ORR catalytic activity of manganese dioxides relies on the redox property of manganese such as changes between $\mathrm{Mn}^{4+}, \mathrm{Mn}^{3+}$, and $\mathrm{Mn}^{2+}$ ions transformation. For example, the valence state of amorphous $\mathrm{MnO}_{\mathrm{x}}$ structure negatively shifted such as from the oxidation state of +3.28 (mixed between $\mathrm{Mn}_{2}{ }^{\mathrm{III}} \mathrm{O}_{3}$ and $\mathrm{Mn}^{\mathrm{IV}} \mathrm{O}_{2}$ ) to +2.85 (mixed between $\mathrm{Mn}_{3}{ }^{\mathrm{IIIII}} \mathrm{O}_{4}$ and $\mathrm{Mn}_{2}{ }^{\mathrm{III}} \mathrm{O}_{3}$ ) [110] during ORR. A more detailed similar explanation of the catalytic mechanism of $\mathrm{MnO}_{2}$ for ORR is illustrated in Figure 14 [111]. It covers the $\mathrm{Mn}(\mathrm{IV}) / \mathrm{Mn}(\mathrm{III})$ redox transition at the surface of the catalyst particles, accompanied by a transformation of adsorbed oxygen $\mathrm{O}_{\mathrm{ad}}$ into adsorbed hydroxy-species $\mathrm{OH}_{\mathrm{ad}}(\mathrm{a})$, the $\mathrm{O}_{2}$ adsorption on the metal oxide surface, which is assumed to occur only on available $\mathrm{Mn}$ (III) surface sites (b), the reduction of the adsorbed $\mathrm{O}_{2}$ molecule into $\mathrm{HO}_{2}^{-}$(c), the desorption/adsorption of $\mathrm{HO}_{2}^{-}$from/onto the $\mathrm{Mn}(\mathrm{III})$ surface site (d), and the reduction of $\mathrm{HO}_{2, \text { ad }}$ which is assumed to occur through a chemical surface process (e) followed back by the initial step (a).

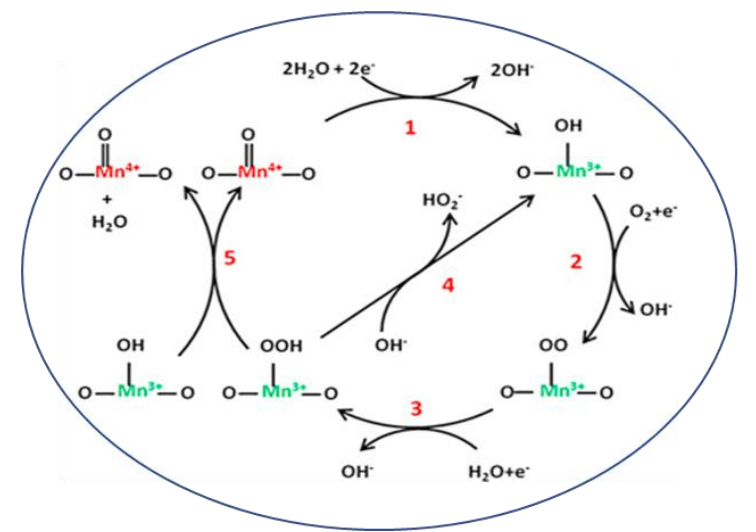

$$
\begin{aligned}
& \mathrm{O}_{\mathrm{ad}}+\mathrm{H}_{2} \mathrm{O}+\mathrm{e}^{-} \leftrightarrows \mathrm{OH}_{\mathrm{ad}}+\mathrm{OH}^{-} \\
& \mathrm{O}_{2}+\mathrm{OH}_{\mathrm{ad}}+\mathrm{e}^{-} \leftrightarrows \mathrm{O}_{2, \mathrm{ad}}+\mathrm{OH}^{-} \\
& \mathrm{O}_{2, \mathrm{ad}}+\mathrm{H}_{2} \mathrm{O}+\mathrm{e}^{-} \leftrightarrows \mathrm{HO}_{2, \mathrm{ad}}+\mathrm{OH}^{-} \\
& \mathrm{HO}_{2, \mathrm{ad}}+\mathrm{OH}^{-} \leftrightarrows \mathrm{OH}_{\mathrm{ad}}+\mathrm{HO}_{2}^{-} \\
& \mathrm{HO}_{2, \mathrm{ad}}+\mathrm{OH}_{\mathrm{ad}} \leftrightarrows 2 \mathrm{O}_{\mathrm{ad}}+\mathrm{H}_{2} \mathrm{O}
\end{aligned}
$$

Figure 14. Proposed oxygen reduction mechanism over Mn(IV) oxide catalyst' $[\mathrm{Mn}$ (III) sites (green) and $\mathrm{Mn}(\mathrm{IV})$ sites (red)] [111].

Birnessite-type of manganese oxide catalyst for ORR:

Only limited research was done on birnessite as an efficient cathode catalyst for the oxygen reduction reaction $[112,113]$. Recently, one study revealed that birnessite type oxide has higher ORR catalytic activity than other dioxide polymorphs [114]. Interlayer molecules such as water, and cations $\left(\mathrm{K}^{+}, \mathrm{Na}^{+}, \mathrm{Ca}^{2+}, \mathrm{Mg}^{2+}\right)$ are playing an essential role in the electrochemical 
property of birnessite. Numerous studies have reported on the effect of the interlayer cation exchanges, and the number of water molecules on the catalytic activity for water oxidation [30] and oxygen evaluation reaction [31]. The relationship between the intercalated alkaline cations $\left(\mathrm{Li}, \mathrm{Na}, \mathrm{K}, \mathrm{Rb}\right.$, and $\mathrm{Cs}$ ) in layered $\delta-\mathrm{MnO}_{x}$ and their ORR catalytic activity is studied in the literature [110]. Interestingly, lithium interlayer cation exhibits higher catalytic activity than other cations. Some studies revealed that also doping of the metals such as copper can improve the catalytic activity of the other types of manganese oxide-based catalysts in ORR such as $\mathrm{Cu}_{\mathrm{x}} \mathrm{Mn}_{3-}$ ${ }_{\mathrm{x}} \mathrm{O}_{4}$ spinel particles/polypyrrole composite [115], graphene-Cu- $\alpha-\mathrm{MnO}_{2}$ nanowire blends [115], and $\mathrm{PtNiCu}$ [118]. Despite these results, no research was done up until now on copper doped delta-manganese oxide catalyzed ORR.

\subsubsection{Manganese oxide catalyst for $\mathrm{CO}_{2}$ hydrogenation}

Nevertheless, many studies explored homogeneous Mn catalysts mechanism in various gas-liquid phase reactions [119], heterogenous manganese oxide-based catalysts are not studied as much in $\mathrm{CO}_{2}$ hydrogenation gas-solid phase reaction [120,121]. As mentioned earlier, the twostep reaction mechanism is assumed for the $\mathrm{CO}_{2}$ hydrogenation reaction. In the first step, carbon dioxide and hydrogen are converted to carbon monoxide $(\mathrm{CO})$ and water $\left(\mathrm{H}_{2} \mathrm{O}\right)$ via the water-gas shift reaction (WGSR) equation (10).

$$
\mathrm{CO}_{2}+\mathrm{H}_{2} \leftrightarrows \mathrm{CO}+\mathrm{H}_{2} \mathrm{O} \Delta \mathrm{H}=41 \mathrm{~kJ} / \mathrm{mol}
$$

In the subsequent (second) reaction, methane is formed from $\mathrm{CO}$ and $\mathrm{H}_{2} \mathrm{O}$ equation (11).

$$
\mathrm{CO}+3 \mathrm{H}_{2} \leftrightarrows \mathrm{CH}_{4}+\mathrm{H}_{2} \mathrm{O} \Delta \mathrm{H}=-206 \mathrm{~kJ} / \mathrm{mol}
$$

As shown in equation (10), the RWGS reaction is endothermic, requires high temperature, and $\mathrm{CO}$ is the dominant product above $600{ }^{\circ} \mathrm{C}$ as can be seen in Figure 15 [122]. Thermostability of catalyst for the RWGS is one of the most important properties to develop catalysts with high activity and durability are essential to obtain a maximum yield. In opposite, methanation is an exothermic reaction equation (11) and maximum yield can be achieved in lower temperatures below $400{ }^{\circ} \mathrm{C}$. 


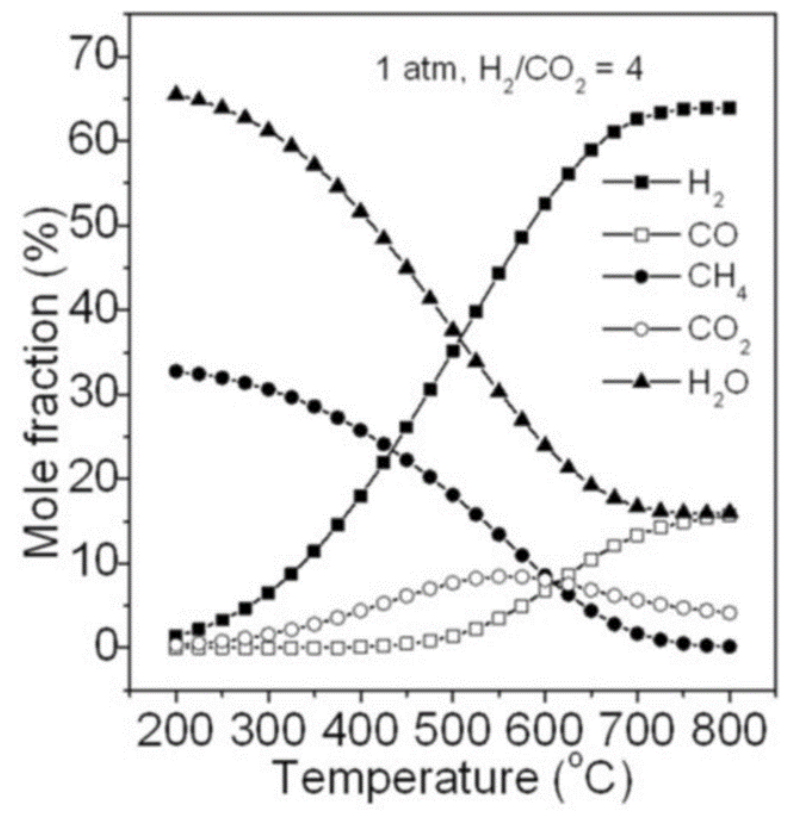

Figure 15. Product fraction of $\mathrm{CO}_{2}$ hydrogenation at equilibrium [123].

$\mathrm{CO}_{2}$ hydrogenation via heterogeneous catalysis typically follows three reaction steps: (1) reactant adsorption on the catalyst surface, (2) diffusion of the adsorbed molecules on the surface until attaching on an active site, (3) transformation until a stable phase is reached and (4) desorption of the final material [124]. A study revealed that non-porous metal oxide catalysts have low porosity and small specific surface area, which is disadvantageous for absorption and activation of reactant molecules and an ordered mesoporous catalyst has good catalytic activity in $\mathrm{CO}_{2}$ RWGS reaction [125]. Therefore, surface properties of the catalyst such as the number of active sites, mesoporous/microporous structure, crystallinity also play a crucial role in the catalytic activity of the catalyst. A detailed explanation of the mechanism of the $\mathrm{CO}_{2}$ hydrogenation reactions (RWGS and methanation) displayed in Figure 16. Here the RWGS mechanism is divided into two main categories; the redox mechanism and associative mechanism [126]. In the redox mechanism, $\mathrm{CO}_{2}$ is firstly adsorbed on the reduced metal sites or metal oxide sites, and then subsequently reacts with them to form CO. After that, the oxidized catalyst is reduced by $\mathrm{H}_{2}$ and the reduced sites are formed again. The associative mechanism, also known as the dissociative (formate) mechanism is an adsorption-desorption model where the adsorbed species interact to form an adsorbed intermediate (carbonate, formate, carbonyl, etc.) as a critical step in the RWGS process which then decomposes to form $\mathrm{H}_{2}$ and a mono-dentate carbonate showed in Figure 16a. The reaction mechanism proposed for $\mathrm{CO}_{2}$ methanation (Figure 16b) is divided into two main categories, associative and dissociative mechanism. The first one involves the direct hydrogenation of $\mathrm{CO}_{2}$ to methane without the formation of $\mathrm{CO}$ as an intermediate. The associative adsorption of $\mathrm{CO}_{2}$ and $\mathrm{H}_{2}$ atom $\mathrm{H}_{\mathrm{ad}}$ is followed by the hydrogenation of the associated species to form methane. The other one involves the conversion of $\mathrm{CO}_{2}$ to $\mathrm{CO}$ before methanation, 
and the subsequent reaction follows the same mechanism as $\mathrm{CO}$ methanation. $\mathrm{CO}$ methanation over supported metal catalysts proceeds via the dissociation of $\mathrm{CO}$ on the metal and the hydrogenation of the resultant surface carbonaceous species.

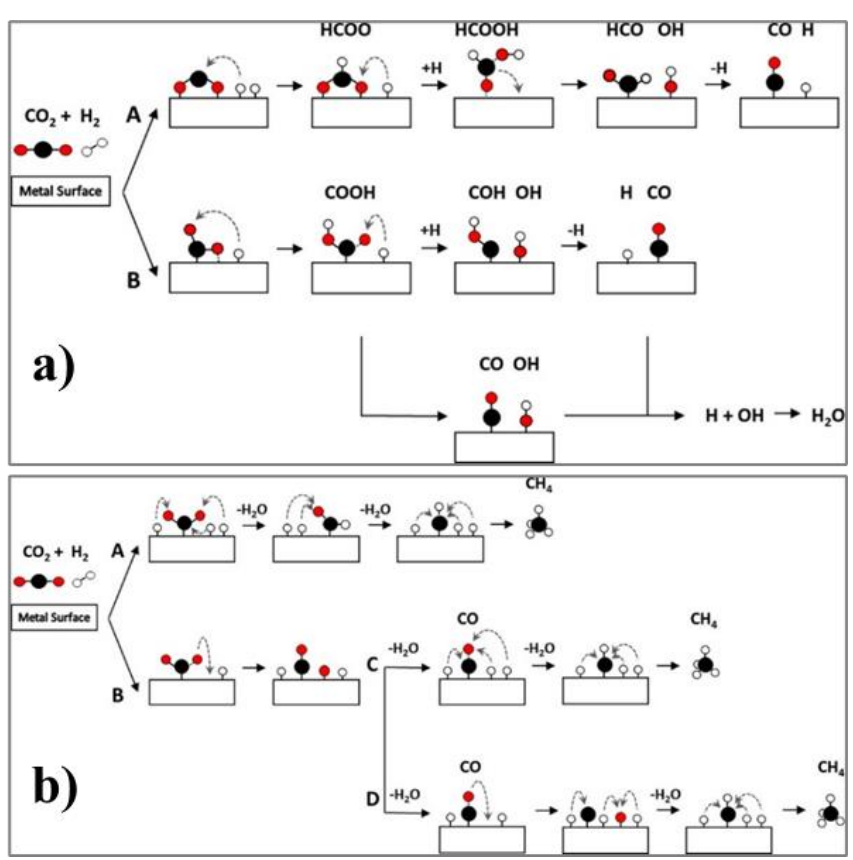

Figure 16. a) Associative mechanism of $\mathrm{CO}$ formation including A-formation of $\mathrm{HCOO}$ intermediate and $\mathrm{B}$-formation of $\mathrm{COOH}$ intermediate and $\mathrm{b}$ ) reaction mechanisms possible for the methanation of $\mathrm{CO}_{2}$ including A-associative methanation, B-dissociative methanation, $\mathrm{C}-\mathrm{CO}$ associative pathway, D-CO dissociative pathway [126].

Furthermore, $\mathrm{CO}_{2}$ reduction and hydrogenation catalyst activity can be improved by a tiny amount of doping or tuning by promoting noble metals such as platinum [127]. Non-noble metal-doped catalysts also exist for $\mathrm{CO}_{2}$ hydrogenation, such as $\mathrm{Cu}$ [128], but they are barely mentioned in literature.

\subsubsection{Manganese oxide electrode for supercapacitor}

Manganese dioxides used in energy storage devices are broadly classified into three groups according to their origin - natural manganese dioxide (NMD), chemical manganese dioxide (CMD), and electrolytic manganese dioxide (EMD) [62]. Despite crystal structure similarities, NMD, CMD and EMD exhibit different physical and electrochemical properties. The natural ore (NMD) is not a single stoichiometric $\mathrm{MnO}_{2}$ but, rather, a mixture of up to 10-20 different manganese oxide minerals that have widely different battery activities, overall NMD has inferior battery performance compared to the other two forms (CMD and EMD). The $\gamma-\mathrm{MnO}_{2}$ prepared chemically (CMD) has a marginal difference in performance compared to the ones derived from electrochemical methods (EMD) [129]. Pseudocapacitive symmetric 
supercapacitors, where both the cathode and the anode have the same pseudocapacitive material, have been widely investigated for developing high-performance supercapacitors.

The working mechanism scheme of the $\mathrm{MnO}_{2}$ based symmetric supercapacitor [130] is illustrated in Figure 17. In the charging process, $\mathrm{MnO}_{2}$ on the positive electrode shows no change, while $\mathrm{MnO}_{2}$ on the negative electrode is reduced to $\mathrm{Mn}^{3+}$ compounds, which enlarges the voltage, and some of these compounds are converted to soluble $\mathrm{Mn}^{2+}$ ions. These $\mathrm{Mn}^{2+}$ ions drift to the positive electrode through the electrolyte with the help of the electric field force. In the recharging process, these $\mathrm{Mn}^{2+}$ ions in the electrolyte near the positive electrode are oxidized to $\mathrm{MnO}_{2}$ on the positive electrode, thus achieving a migration of mass from the negative to the positive electrode. The pristine $\mathrm{MnO}_{2}$ on the positive electrode shows no large change but is only being oxidized to complete $4+$ valences in the charging process. As a result, in the cyclic charging/discharging process of the $\mathrm{MnO}_{2}$ based symmetric supercapacitor, a new layer of $\mathrm{MnO}_{2}$ is coated on the pristine $\mathrm{MnO}_{2}$ layer of the positive electrode, and the mass of $\mathrm{MnO}_{2}$ on the negative electrode decreases.

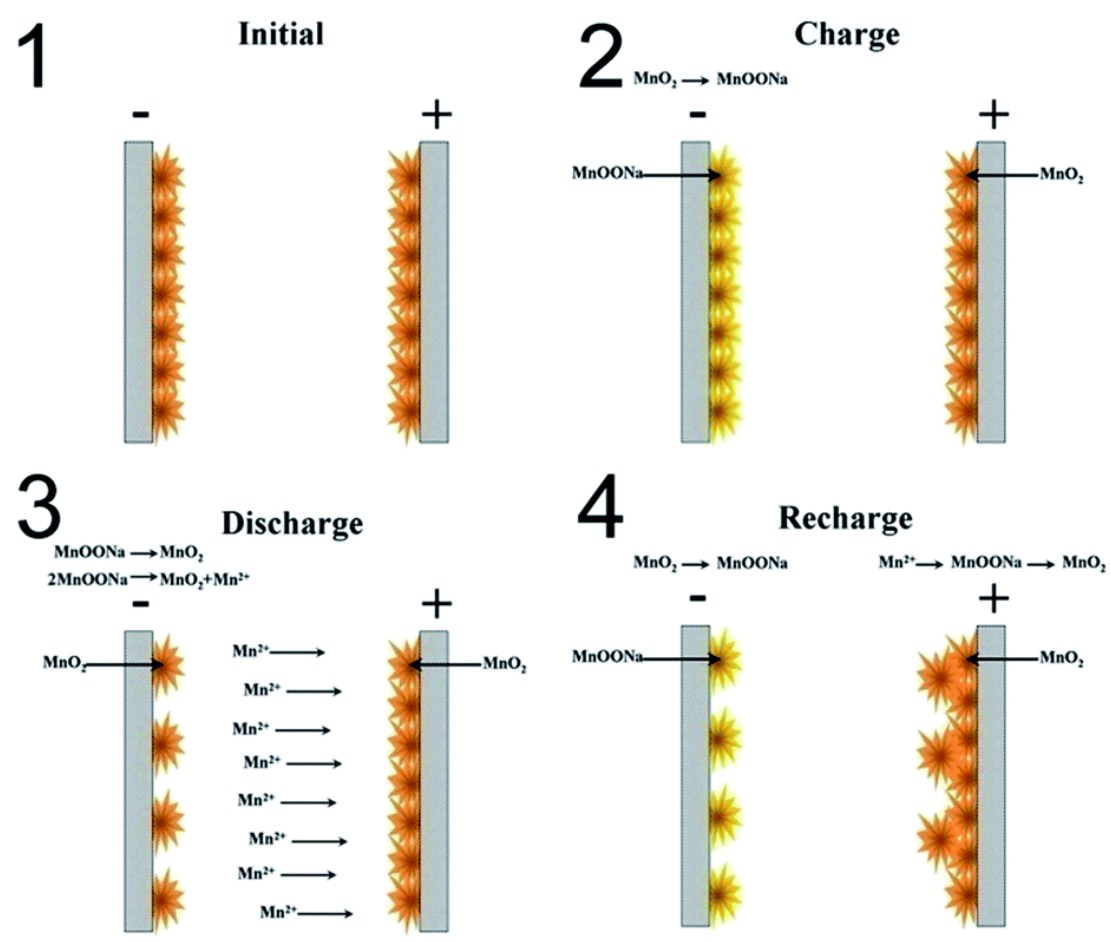

Figure 17. The working mechanism of the $\mathrm{MnO}_{2}$ based symmetric supercapacitor [130].

Manganese oxide-based supercapacitors' biggest problem is stability. Due to various changes in the oxidation states, the structure and stability of the electrode material change unpredictably in the long term. Therefore, a binding material such as organic binders-polymers is used to stabilize the operation [131]. 


\section{Aims}

To find answers to all these questions, manganese (Mn) was selected as the subject of my research, since it is cheap and it is one of the most abundant transition metals (after iron) in the Earth's crust. Due to a wide variety of oxidation states and crystal structures, manganese can have many morphological and physicochemical attributes, therefore, it can be a component for numerous applications. As an environmental chemist, I aimed to find and develop an eco-friendly, cost-effective, safe, simple method for synthesis of nanostructured manganese-based materials, characterize the physicochemical properties, and finally test the synthesized materials for the previously mentioned environmental applications such as oxygen reduction reaction (ORR), $\mathrm{CO}_{2}$ hydrogenation and supercapacitor:

I. To develop the synthesis method of birnessite-like manganese dioxide and test the catalytic activity of the as-synthesized material in the oxygen reduction reaction.

- Developing a synthesis method of birnessite-like manganese dioxide

- Studying physicochemical properties and intercalated ion effects of the initial birnessite and newly developed copper birnessite

- Testing catalytic activity of the potassium birnessite (initial) and copper birnessite for ORR

II. To investigate a new method to produce nanosized manganese oxides, which is easy to upscale to allow mass production of the material. Also, to develop a one-pot synthesis method for different metal doping of the same material and compare the results.

- Finding optimum conditions for the synthesis of nanosized manganese oxides by ball milling

- Studying the physicochemical properties of the newly synthesized nano manganese oxide samples

- Testing catalytic activity of the newly synthesized manganese oxides for $\mathrm{CO}_{2}$ hydrogenation reaction and studying the metal loading ( $P t$ and $\mathrm{Cu}$ ) and the effect of Pt incorporation into the catalysts

III. To investigate a more economical and direct new method for the synthesis of manganese nanostructured materials from natural manganese minerals as precursors instead of synthetic chemicals.

- Developing new synthesis routine of manganese nanosized oxides from the mineral sample

- Studying physicochemical properties of the newly synthesized nano manganese oxide sample

- Testing electrochemical properties as a supercapacitor electrode 


\section{Resources and methods}

\subsection{Materials}

Ion tuned birnessite-like manganese dioxide in alkaline media:

Manganese (II) chloride tetrahydrate $\left(\mathrm{MnCl}_{2} * 4 \mathrm{H}_{2} \mathrm{O}\right)$, potassium permanganate $\left(\mathrm{KMnO}_{4}\right)$, copper (II) chloride $\left(\mathrm{CuCl}_{2}\right)$, and sodium hydroxide $(\mathrm{NaOH})$ were used for the synthesis of the manganese-oxide nanostructures. All chemicals and reagents were analytical grade and purchased from Sigma Aldrich. Ultrapure water $(3.58 \mu \mathrm{S} / \mathrm{cm})$ was used for all synthesis.

\section{Ball milled manganese oxides:}

Manganese (II) chloride tetrahydrate $\left(\mathrm{MnCl}_{2} * 4 \mathrm{H}_{2} \mathrm{O}\right)$, potassium permanganate $\left(\mathrm{KMnO}_{4}\right)$, platinum (IV) chloride $\left(\mathrm{H}_{2} \mathrm{PtCl}_{6} \mathrm{xH}_{2} \mathrm{O}\right)$, and sodium hydroxide $(\mathrm{NaOH})$ were used for the synthesis of the manganese-oxide nanostructures. All chemicals and reagents were analytical grade and purchased from Sigma Aldrich. Ultrapure water $(3.58 \mu \mathrm{S} / \mathrm{cm})$ was used for all synthesis.

\section{Natural mineral inspired manganese oxide thin layer:}

A piece of brown-black manganese mineral sample was used for further processing. The sample received from the Geological Department of the University of Szeged and the origin of the mineral is Úrkút, Hungary (see Figure 9).

\subsection{Synthesis of different manganese oxides}

A short description of all synthetic procedures and names of the prepared samples are described in Table 4.

Table 4. The synthetic procedure of the manganese-oxide samples.

\begin{tabular}{|c|c|c|c|}
\hline \multirow[b]{2}{*}{ Projects } & \multicolumn{3}{|l|}{ Synthesis details } \\
\hline & $\begin{array}{l}\text { Synthesis } \\
\text { method }\end{array}$ & Dopant & Sample name (code) \\
\hline $\begin{array}{l}\text { Ion-tuned birnessite for } \\
\text { ORR catalyst }\end{array}$ & $\begin{array}{l}\text { Precipitation in } \\
\text { alkaline media }\end{array}$ & $\begin{array}{l}\mathrm{K} \\
\mathrm{Cu}\end{array}$ & $\begin{array}{l}\text { Birnessite } \\
\mathrm{Cu}^{2+} / \text { Birnessite }\end{array}$ \\
\hline $\begin{array}{l}\text { Manganese oxides for } \\
\mathrm{CO}_{2} \text { hydrogenation }\end{array}$ & $\begin{array}{l}\text { Mechanochemical } \\
\text { ball-milling }\end{array}$ & $\begin{array}{l}\mathrm{Pt} \\
\mathrm{Cu}\end{array}$ & $\begin{array}{l}\text { M200, M450, M600, } \\
\text { M200(Cu-milled), M450(Cu- } \\
\text { milled), M600(Cu-milled), } \\
\text { M200(Pt-milled), M450(Pt- } \\
\text { milled), } \\
\text { M600 (Pt-milled), } \\
\text { M600 (Pt-impregnated) } \\
\text { M600 (5nm Pt-sonicated) }\end{array}$ \\
\hline $\begin{array}{l}\text { Manganese oxide } \\
\text { electrode for } \\
\text { supercapacitor }\end{array}$ & $\begin{array}{l}\text { Electrochemical } \\
\text { deposition }\end{array}$ & - & $\begin{array}{l}\text { MnOx-I } \\
\text { MnOx-M } \\
\text { MnOx-D/CP }\end{array}$ \\
\hline
\end{tabular}




\subsubsection{Synthesis of ion-tuned birnessite in alkaline media}

\section{Initial potassium birnessite (Birnessite):}

Three aqueous solutions were used for the synthesis of Birnessite: $1.75 \mathrm{ml}$ of $\mathrm{KOH}$ $\left(8.8 \mathrm{~mol} \mathrm{~L}^{-1}\right), 2.125 \mathrm{ml} \mathrm{KMnO}_{4}\left(0.1 \mathrm{~mol} \mathrm{~L}^{-1}\right)$ and $3.75 \mathrm{ml} \mathrm{MnCl}_{2}\left(0.6 \mathrm{~mol} \mathrm{~L}^{-1}\right)$. The synthesis method [132] used and the mixing of $\left(\mathrm{MnCl}_{2}\right)$ and $\mathrm{KMnO}_{4}$ solutions under vigorous stirring for 2 hours then $\mathrm{KOH}$-solution was dropwise added into this mixture. The mixture was then stirred for another $30 \mathrm{~min}$ and aged at $60{ }^{\circ} \mathrm{C}$ for 16 hours. The final product was centrifuged and washed until the $\mathrm{pH}$ of the solution settled between 8-9 and dried at $60{ }^{\circ} \mathrm{C}$ overnight.

\section{$\mathrm{Cu}^{2+} /$ Birnessite structure:}

$\mathrm{MnCl}_{2}\left(0.5\right.$ mol L-1) and $\mathrm{KMnO}_{4}\left(0.1\right.$ mol L-1) mixed with $\mathrm{CuCl}_{2}(0.1 \mathrm{~mol} \mathrm{~L}-1)$ for 2 hours then $\mathrm{KOH}\left(8.8 \mathrm{~mol} \mathrm{~L}^{-1}\right)$ solution was added dropwise into this mixture. The reaction mixture was then stirred for another $30 \mathrm{~min}$ and aged at $60{ }^{\circ} \mathrm{C}$ for 48 hours. The copper tuned birnessite was finally centrifuged and washed until the $\mathrm{pH}$ of the solution settled between 8-9 and dried at $60{ }^{\circ} \mathrm{C}$ overnight.

\subsubsection{Synthesis of manganese oxide using a ball milling method}

Pure $\mathrm{MnO}_{x}$ samples $(\mathrm{M} 200, \mathrm{M} 450$, M600)

The samples were synthesized by the mechanochemical method with different milling speeds as categorized ball milling (pure samples). $\mathrm{MnCl}_{2} * 4 \mathrm{H}_{2} \mathrm{O}$ and $\mathrm{KMnO}_{4}$ with a 1:0.5 molar ratio was mixed with $0.09 \mathrm{M}$ of sodium hydroxide and $5 \mathrm{ml}$ of water. The mixture was filled into a hardened stainless-steel grinding bowl (inner diameter:7.5 mm - volume: $250 \mathrm{ml}$ ) of a Planetary Mono Mill Pulverisette 6 (Fritsch GmbH, Germany) ball-miller equipped with twenty-five hardened stainless-steel grinding balls of $4 \mathrm{~g}$ weight and $10 \mathrm{~mm}$ diameter. The mixtures were milled at speed of $200 \mathrm{rpm}, 450 \mathrm{rpm}$ and $600 \mathrm{rpm}$ for 4 hours. The products were washed with water and freeze-dried for a night ( $>8$ hours). The resulting products were labeled as M200, M450, and M600 corresponding to manganese-oxide samples prepared with $200 \mathrm{rpm}, 450 \mathrm{rpm}$ and $600 \mathrm{rpm}$ milling speed respectively.

\section{Metal-doped $\mathrm{MnO}_{x}$ samples:}

M200(Cu-milled), M450(Cu-milled), M600(Cu-milled), M200(Pt-milled), M450(Ptmilled), and M600(Pt-milled) samples synthesized by the mechanochemical method as categorized ball milling (metal-doped). $0.0005 \mathrm{M}$ platinum (IV) chloride or $0.0005 \mathrm{M}$ copper (II) chloride was added into the mixture of the manganese-oxide precursors before the milling process. The same quantity of precursors, milling time and milling speeds (200 rpm, $450 \mathrm{rpm}$ and $600 \mathrm{rpm}$ ) were used as in the case of the pure Manganese- 
oxide based catalysts. The final product was obtained after filtration, washing with water followed by freeze-drying overnight.

Pt loaded M600 samples were prepared by two other methods to study the effect of platinum incorporation:

Pt loading from $\mathrm{H}_{2} \mathrm{PtCl}_{6}$ by wet impregnation (M600-Pt-impregnated): The required amount of $\mathrm{H}_{2} \mathrm{PtCl}_{6} \cdot \mathrm{xH}_{2} \mathrm{O}$ (to reach three wt.\% of metallic $\mathrm{Pt}$ ) dissolved into a determined amount of ethanol. The ethanol suspension was filtrated into the pores of the M600 manganese oxide support. The supported catalyst was dried overnight.

\section{Size-controlled $5 \mathrm{~nm}$ Pt nanoparticles loading by sonication (M600-5nm Pt-sonicated):}

First, 5 nm diameter Pt nanoparticles were produced [133]. Here, 0.04 g Platinum (II) acetylacetonate and $0.035 \mathrm{~g}$ polyvinylpyrrolidone (PVP, MW $=40,000)$ was dissolved in $5 \mathrm{ml}$ ethylene-glycol and ultra-sonicated for 30 minutes to get a homogenous solution. The solution was poured into a three-necked round bottom flask and was evacuated and purged with atmospheric pressure argon gas for several cycles to get rid of additional oxygen and water. After three purging cycles, the flask was immersed into an oil bath heated up to $473 \mathrm{~K}$ under vigorous stirring of the reaction mixture as well as the oil bath. After 10 minutes of reaction, the flask was cooled down to room temperature. The suspension was precipitated by centrifugation with the coadding of acetone to the reaction mixture. The nanoparticles are washed by centrifuging with hexane and redispersing in ethanol for at least 2-3 cycles and finally resuspended in ethanol. The concentration of the Pt nanoparticles was measured by the ICP technique. To fabricate manganese-oxide supported Pt nanoparticle catalysts, the ethanol suspension of $5 \mathrm{~nm} \mathrm{Pt}$ nanoparticles and M600 manganese oxide were mixed in ethanol and sonicated in an ultrasonic bath $(40 \mathrm{kHz}, 80 \mathrm{~W})$ for 3 hours [134]. The supported nanoparticles were collected by centrifugation. The products were washed with ethanol three times before they were left for a night ( $>8$ hours) to dry at $353 \mathrm{~K}$ temperature.

\subsubsection{Synthesis of manganese oxide nanostructures from the mineral}

Preparation of the initial manganese oxide (MnOx-I):

Manganese mineral (MnOx-I) is mechanically crushed to a suitable size by the milling machine.

Preparation of milled manganese oxide $(\mathrm{MnOx}-\mathrm{M})$ :

The first step of the milling process was dry milling. The crushed mineral sample was milled with 20 steel balls each one with $4 \mathrm{~g}$ weight together in a Ni/Fe/Cr milling bowl, which has 
$200 \mathrm{ml}$ volume and $50 \mathrm{~mm}$ diameter. The milling speed was set to $450 \mathrm{rpm}$ and the milling reverse time was 15 minutes. The total time duration of the dry milling process was 2 hours.

The second step of the milling process was wet milling. About $5 \mathrm{ml}$ ultrapure water was added into the milling bowl, which contained all the components. It was milled for another 2 hours with the same milling speed and set to reverse every 15 minutes. After the second milling step, the sample was collected in a vacuum filtering device and it was washed 3 times with water and 3 times with ethanol solution separately. The filtered product was dried in a freeze drier overnight and collected in a sample tube, where it was kept in dry condition.

Preparation of the solution from as prepared $\mathrm{MnO}_{x}:$

A specific amount ( $0.03 \mathrm{~g}$ ) of MnOx-M was dissolved in $20 \mathrm{ml}$ oxalic acid (0.1M). As shown in equation (12) oxalic acid reacts with manganese dioxide and forming carbon dioxide gas bubbles and manganese oxalate acidic solution[135]. Later undissolved residues such as silica, iron oxides from the mineral composites, were separated by a 0.45 -micrometre membrane. After that, about $30 \mathrm{ml}, \mathrm{NaOH}(0.1 \mathrm{M})$ was added to the filtered manganese oxalate solution. The colour of the solution was changed from yellowish (Figure 18. (I)) to a weak pink colour [136] and the pH settled at 3-4 (weakly acidic) (Figure 18. (II)). The volume ratio of the oxalic acid and sodium hydroxide was $1: 1.5$. The predicted chemical synthesis of the formed pink mixture is written in equation (13). As shown in the equation, $3 \mathrm{H}^{+}$still in the solution and can prevent $\mathrm{Mn}(\mathrm{OH})_{3}$ precipitation.

$$
\begin{aligned}
& \mathbf{2} \mathbf{M n}^{4+} \mathrm{O}_{2}+7 \mathrm{H}_{2} \mathrm{C}_{2} \mathrm{O}_{4}=\mathbf{M n}^{3+}{ }_{2}\left[\mathbf{C}_{2} \mathrm{O}_{4}\right]_{3}+8 \mathrm{CO}_{2} \uparrow+4 \mathrm{H}_{2} \mathrm{O}+6 \mathrm{H}^{+} \\
& \mathbf{2} \mathbf{M n}^{4+} \mathrm{O}_{2}+7 \mathrm{H}_{2} \mathrm{C}_{2} \mathrm{O}_{4}+6 \mathrm{NaOH}=2 \mathrm{Mn}(\mathbf{O H})_{3} \downarrow+8 \mathrm{CO}_{2} \uparrow+3 \mathrm{Na}_{2} \mathrm{C}_{2} \mathrm{O}_{4}+7 \mathrm{H}_{2} \mathrm{O}+3 \mathrm{H}^{+}
\end{aligned}
$$

When the volume ratio of the oxalic acid and sodium hydroxide exceeds 1:1.5, reaching a ratio of 1: 2 or even higher, $\mathrm{pH}$ becomes higher than 7. Due to sodium hydroxide reducing ability, the manganese oxalate complex reduces, and manganese hydroxide formation can take place in the solution.

\section{The electrochemical and electrophoretic deposition of the manganese oxide (MnOx-D/CP):}

Zeta-potential of the formed particles during electrochemical reactions and deposition of the manganese oxide (MnOx-D/CP) shown in Figure 18. The electrochemical deposition process took place in a small glass cell containing two electrodes. The cathodic and anodic electrodes are the same carbon paper electrodes with a height of $2 \mathrm{~cm}$ and width of $1 \mathrm{~cm}$ immersed in the solution. The complex electrochemical process took place in the cell. First, manganese oxalate and manganese hydroxide were reduced at the cathode with the formation of the hydroxide group as the electrolysis product. Then negatively charged manganese hydroxide particles moved 
toward the anode [137] as showed in Figure 18. (III) and electrophoretic deposition took place at the anode (Figure 18. (IV)). The deposited manganese electrode was washed with ultra-pure water and dried at $200^{\circ} \mathrm{C}$ for 2 hours.

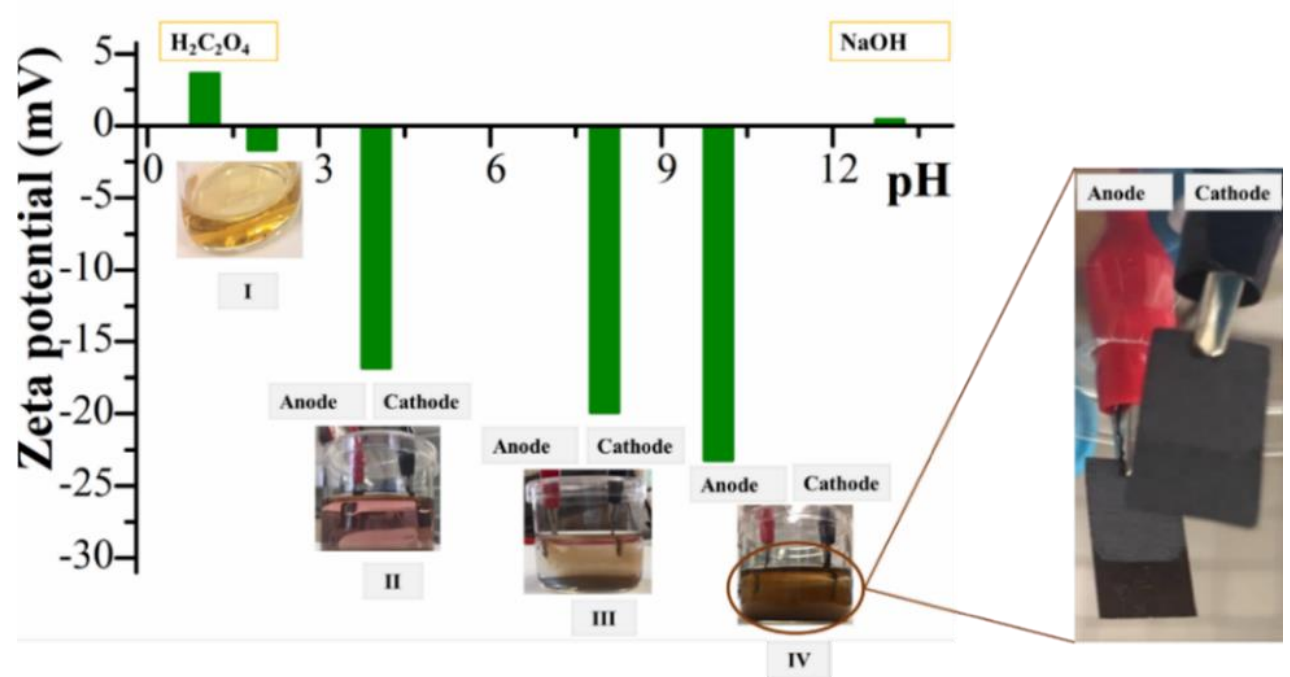

Figure 18. Manganese solution in oxalic acid (I), manganese solution with sodium hydroxide in $\mathrm{pH} 3-4$ (II), the electrochemical formation of $\mathrm{Mn}(\mathrm{OH})_{2}$ at the cathode and electrophoretic movement toward the anode (III), and deposited final product on anode after 3 hours (IV).

\subsection{Characterization techniques}

\section{$X$-ray diffractometry}

Rigaku Miniflex II powder X-ray diffractometer using a $\mathrm{Cu} \mathrm{K} \alpha$ radiation source $(\lambda=0.15 \mathrm{~nm})$ operating at $30 \mathrm{kV}$ voltage and $15 \mathrm{~mA}$ current at room temperature. For crystal structure characterization a scanning rate of 0.5 degree $\cdot \mathrm{min}^{-1}$ in the $4-80^{\circ} 2 \theta$ range was used.

\section{Raman spectroscopy}

The Raman spectra were collected using a SENTERRA Raman microscope (Bruker Optics, Inc.) applied power $0.25 \mathrm{~mW}$ at $532 \mathrm{~nm}$ with 1s integration time (with three repetitions) at a resolution of $4 \mathrm{~cm}^{-1}$ and an interferometer resolution of $0.5 \mathrm{~cm}^{-1}$.

\section{Thermal analytical measurements}

The thermal behaviour of the samples was investigated using thermogravimetry (TA Instruments Q500 TGA). The instrument worked from RT - $750{ }^{\circ} \mathrm{C}$ under both air and nitrogen atmosphere, where the heating rate was $5{ }^{\circ} \mathrm{C} / \mathrm{min}$. All the samples were weighted between 5-20 mg and they were placed into high-purity alpha platinum crucibles. Differential scanning calorimetric analysis was performed by Q20 (TA Instruments) at RT $-600{ }^{\circ} \mathrm{C}$ under constant airflow and the heating-cooling rate was $5{ }^{\circ} \mathrm{C} / \mathrm{min}$.

\section{Microscopic techniques}

High-resolution Transmission Electron Microscopy HR-TEM (FEI TECNAI G ${ }^{2} 20$ XTWIN) operated at $200 \mathrm{kV}$ accelerating voltage and Scanning Electron Microscope (Hitachi S- 
4700 Type II instrument operated at $30 \mathrm{kV}$ accelerating voltage with integrated with EDS) were used to do morphological and compositional studies.

\section{$X$-ray photoelectron microscopy}

For the analysis of the oxidation states of the manganese catalysts, XPS spectra were collected with a SPECS XPS instrument equipped with an XR-50 dual anode X-ray source and a PHOIBOS 150 energy analyzer. All spectra were acquired with Al Ka source operated at $150 \mathrm{~W}$ $(14 \mathrm{kV})$. Survey spectra were collected with a step size of $1 \mathrm{eV}$ and $40 \mathrm{eV}$ pass energy, collecting 1 sweep for each sample. High-resolution spectra of Mn 2p, C 1s, O 1s and Pt 4f regions (the latter three not shown) were acquired with $20 \mathrm{eV}$ pass energy and step sizes of $0.1 \mathrm{eV}$. The $\mathrm{Mn}$ $2 \mathrm{p}$ regions were fitted with multiplet states taken into consideration, which method was described by Ilton et al. [138]. Briefly, when determining the spectra of mixed oxides of $\mathrm{Mn}(\mathrm{II}), \mathrm{Mn}$ (III) and $\mathrm{Mn}(\mathrm{IV})$ the data of pure oxides could be used as a starting parameter. These parameters include peak positions in binding energies, intensity ratios and FWHM values. Due to the complicated nature of this method, the $\mathrm{Mn} 2 \mathrm{p} 1 / 2$ regions were not used for the evaluation. A prepeak at lower binding energies $(\sim 640 \mathrm{eV})$ was added, which corresponds to lattice defects.

\section{Surface analysis}

The Brunauer-Emmett-Teller (BET) surface area and pore radius were measured with a 3H-2000 BET-A surface area analyzer.

\section{Zeta potential analysis}

For characterization of the aggregation state of nanoparticles, the hydrodynamic diameter (number distribution) of birnessite particles was determined at $25 \pm 0.1{ }^{\circ} \mathrm{C}$ using dynamic light scattering (DLS) method with an apparatus of NanoZS (Malvern) with a $4 \mathrm{~mW}$ HeNe laser source $\left(\lambda=633 \mathrm{~nm}\right.$ ) operating in backscattering mode at an angle of $173^{\circ}$ using disposable zeta cells (DTS 1060). The dispersions were diluted to get an optimal intensity; thus, the samples contained $\sim 100 \mathrm{mg} \mathrm{L}^{-1}$ solid particles. Before the measurements, the samples were homogenized in an ultrasonic bath for $10 \mathrm{~s}$, after which 1.5 min relaxation took place. Any changes in the aggregation state of the nanoparticles in aqueous dispersions were characterized by the hydrodynamic diameter. The effect of $\mathrm{pH}$ variation (between 1 and 13) for the different birnessite particles (Birnessite, $\mathrm{Cu}^{2+} /$ Birnessite) was studied at $10 \mathrm{mmol} \mathrm{L}^{-1} \mathrm{NaCl}$. For evaluation, we used the second- or third-order cumulant fit of the autocorrelation functions, depending on the degree of polydispersity. The electrophoretic mobility of birnessite dispersions was measured at $25 \pm 0.1{ }^{\circ} \mathrm{C}$ in the same Nano ZS (Malvern) apparatus used for DLS measurements. The Smoluchowski equation was applied to convert electrophoretic mobility to the zeta potential value. The accuracy of the measurements was $\pm 5 \mathrm{mV}$. The samples for the zeta potential study were the same 
preparation for the DLS, and the electrophoretic mobility measurements were performed immediately after the DLS measurements.

\subsection{Methods and electrochemical experiment setup}

\subsubsection{The catalyst for oxygen reduction reaction (ORR)}

\subsubsection{Electrode preparation for oxygen reduction reaction (ORR)}

The surface coating of the glassy carbon electrode (GCE, 3mm diameter, $\mathrm{BASi}^{\circledR}$ ), was processed by a surface polishing method with an alumina slurry $(0.05 \mu \mathrm{m}$ diameter) then it was rinsed and sonicated with ion-exchanged water and ethanol, then dried. The birnessite sample was mixed with carbon black with a 1:1 weight ratio and was dispersed ultrasonically in a 1:1 V/V ratio mixture of ethanol and water $(250 \mu \mathrm{l})$ with an addition of $10 \mu \mathrm{l}$ of $5 \mathrm{wt} \%$ Nafion ${ }^{\circledR}$ to get a homogeneous suspension with the weight concentration of $8.0 \mathrm{mg} \cdot \mathrm{mL}^{-1}$. To form a surfacemodified glassy carbon electrode, $7.5 \mu \mathrm{l}$ of this suspension was dropped onto the surface of the pretreated glassy carbon electrode and dried in the air, at room temperature. It corresponds to a catalyst loading of $0.85 \mathrm{mg} \mathrm{cm}^{-2}$ on the geometric area of GCE.

\subsubsection{Electrochemical oxygen reduction reaction test}

The electrochemical oxygen reduction reaction (ORR) and the durability of the composites were investigated in a three-electrode glass cell using an ACM Instruments GILL AC electrochemical workstation at $23^{\circ} \mathrm{C}$. The working electrode was a surface modified glassy carbon electrode (the preparation of which was described above), while $\mathrm{Ag} / \mathrm{AgCl}\left(3 \mathrm{M} \mathrm{NaCl}, \mathrm{BASi}{ }^{\circledR}\right)$ and a platinum wire served as reference and counter electrodes, respectively. The voltammetry measurements were carried out in nitrogen or oxygen saturated $0.1 \mathrm{M} \mathrm{KOH}$ solution. The measured potentials vs $\mathrm{Ag} / \mathrm{AgCl}(3 \mathrm{M} \mathrm{NaCl})$ were converted to the reversible hydrogen electrode (RHE) scale according to the following equation (14):

$$
E(v S R H E)=E+E_{A g / A g C l}(v S S H E)+0.059 \mathrm{~V} \cdot p H
$$

where $E$ is the experimentally measured potential vs $\mathrm{Ag} / \mathrm{AgCl}$ reference electrode, SHE stands for the standard hydrogen electrode, and $E_{A g / A g C l}(v S S H E)=0.201 \mathrm{~V}$ at $23{ }^{\circ} \mathrm{C}$. Electrocatalytic activity of the working electrodes was investigated by using cyclic voltammetry (CV) in the potential range between 0 and $-1000 \mathrm{mV}$ vs $\mathrm{Ag} / \mathrm{AgCl}(3 \mathrm{M} \mathrm{NaCl})$ at a scan rate of $10 \mathrm{mVs}^{-1}$. Linear sweep voltammetry (LSV) measurements with a rotating disk electrode (RDE) were carried out in the same potential range with a rotation rate between 500 and $2500 \mathrm{rpm}$. The linear sweep voltammograms are depicted and used after background correction. 


\subsubsection{Electrochemical stability of the Birnessite}

The electrochemical stability of the as-prepared catalysts was measured by the chronoamperometric method. The current retention vs operating time curves were registered to apply a constant potential of $0.4 \mathrm{~V}$ (vs RHE) in oxygen-saturated $0.1 \mathrm{M} \mathrm{KOH}$ solution at $1500 \mathrm{rpm}$ rotating rate with 10000 second operation time.

\subsubsection{Catalytic $\mathrm{CO}_{2}$ hydrogenation reaction over manganese-oxide catalysts}

\subsubsection{Pretreatment}

Before the catalytic experiments, the catalysts were oxidized in the $\mathrm{O}_{2}$ atmosphere at 300 ${ }^{\circ} \mathrm{C}$ for 30 min to remove the surface contaminants as well as the PVP capping agent after that oxygen was removed from the system by flowing Ar gas for 15 minutes. Then the catalyst sample was reduced in $\mathrm{H}_{2}$ at $300{ }^{\circ} \mathrm{C}$ for $60 \mathrm{~min}$.

\subsubsection{Hydrogenation of carbon dioxide in a continuous flow reactor}

Catalytic reactions were carried out at atmospheric pressure in a fixed-bed continuousflow reactor ( $200 \mathrm{~mm}$ long with $8 \mathrm{~mm}$ i.d.) and heated externally. The dead volume of the reactor was filled with quartz beads. The operating temperature was controlled with a thermocouple placed inside the oven close to the reactor wall, to assure precise temperature. For catalytic studies, small fragments (about $1 \mathrm{~mm}$ ) of slightly compressed pellets were used. Typically, the reactor filling contained $150 \mathrm{mg}$ of catalyst. In the reacting gas mixture, the $\mathrm{CO}_{2}: \mathrm{H}_{2}$ molar ratio was 1:4, if not denoted otherwise. The $\mathrm{CO}_{2}: \mathrm{H}_{2}$ mixture was fed with the help of mass flow controllers (Aalborg), the total flow rate was $50 \mathrm{ml} / \mathrm{min}$. The reacting gas mixture flow entered and left the reactor through an externally heated tube to avoid condensation. The analysis of the products and reactants were performed with an Agilent $6890 \mathrm{~N}$ gas chromatography equipped with an HP-PLOTQ column. The gases were detected simultaneously by thermal conductivity (TC) and flame ionization (FI) detectors. The $\mathrm{CO}_{2}$ was transformed by a methanizer to methane before analysis with FID.

\subsubsection{Electrochemical electrode preparation for capacitance test (CV, GCD, EIS)}

Electrochemical measurements were performed on the electrochemical station potentiostat/galvanostat instrument (Autolab PGSTAT302N, Metrohm Autolab B.V.) in $\mathrm{KOH}$ $(0.1 \mathrm{M})$ aqueous solution. The working electrode was a bare carbon paper electrode and $\mathrm{MnOx}-$ $\mathrm{D} / \mathrm{CP}$, while $\mathrm{Ag} / \mathrm{AgCl}\left(3 \mathrm{M} \mathrm{NaCl}, \mathrm{BASi}{ }^{\circledR}\right)$ and a platinum wire served as a reference and counter electrode, respectively. The capacitance of the working electrodes was investigated by using cyclic voltammetry $(\mathrm{CV})$ in the potential range between 0 and $-1 \mathrm{~V}$ vs $\mathrm{Ag} / \mathrm{AgCl}(3 \mathrm{M} \mathrm{NaCl})$ at different scan rates between $0.005-0.05 \mathrm{Vs}^{-1}$. Specific capacitance retention measured with 
2100 cycles of CV. The galvanostatic charge-discharge measurement was carried out with a current density of $0.1 \mathrm{~A} / \mathrm{g}-2 \mathrm{~A} / \mathrm{g}$ and a potential limit(cut-off) of $0.5 \mathrm{~V}$. EIS measurement was performed in the frequency range of $10,000 \mathrm{~Hz}-0.001 \mathrm{~Hz}$.

\section{Results and discussions}

\subsection{Characterization results of the manganese oxides}

\subsubsection{Characterization results of the Birnessite in alkaline media}

\subsubsection{Structural determination and chemical characterization}

X-ray diffraction (XRD) patterns of the potassium birnessite (Birnessite) and copper intercalated one $\left(\mathrm{Cu}^{2+} /\right.$ Birnessite) are shown in Figure 19a. The two main reflection peaks can be observed at $12.63^{\circ}\left(\mathrm{d}_{\text {spacing }}=0.69 \mathrm{~nm}\right.$ calculated from Bragg's equation [139]) and $24.8^{\circ}$ $\left(\mathrm{d}_{\text {spacing }}=0.36 \mathrm{~nm}\right)$ correspond to the $(001)$ and (002) crystal planes of Birnessite, respectively $[132,140]$. The addition of the copper-ions resulted in a slight shift of (001) reflection from $12.81^{\circ}$ $\left(\mathrm{d}_{\text {spacing }}=0.69 \mathrm{~nm}\right)$ to $12.63^{\circ}\left(\mathrm{d}_{\text {spacing }}=0.70 \mathrm{~nm}\right)($ Figure 19b). The interlayer distance expansion can be attributed to the bigger size of the copper-ions as well as the higher amount of total interlayer cations [141] in Figure 19(c-d). In the case of the pristine Birnessite, the reflection at 27.0 $\left(\mathrm{d}_{\text {spacing }}=0.32 \mathrm{~nm}\right)$ corresponds to the impurity raised from manganite $(\mathrm{MnO}(\mathrm{OH}))$ which is an intermediate phase during the birnessite formation. However, this phase is not observable for the copper intercalated birnessite structure. A weak reflection at $\sim 19^{\circ}$ and $\sim 35^{\circ}$ appears, which refers to the presence of a small amount of the tunnel structured $\left(\alpha-\mathrm{MnO}_{2}\right)$ cryptomelane [142] as a result of a longer ageing process.

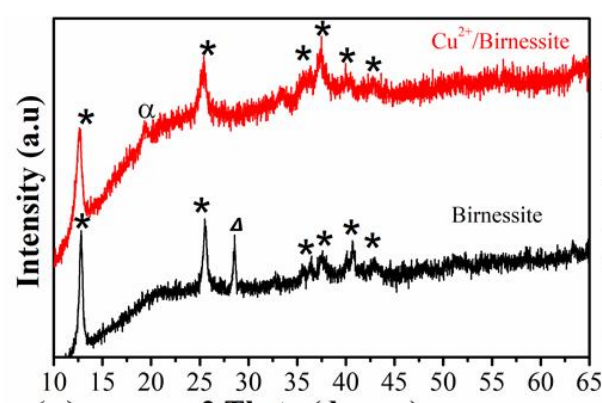

(a)

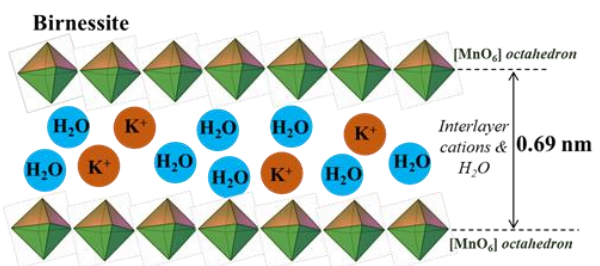

(c)
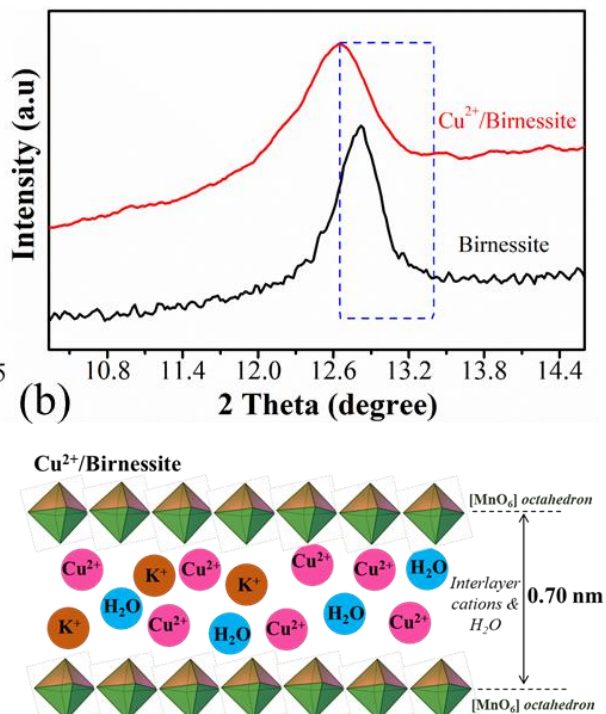

(d)

Figure 19. X-ray diffraction patterns (a-b) $\left\{\mathrm{XRD}\right.$ patterns: * -birnessite, $\boldsymbol{\alpha}$ - tunnel structured $\left(\mathrm{MnO}_{2}\right), \Delta$ manganite $\mathrm{MnO}(\mathrm{OH})\}$ and illustration of interlayer distance and intercalated cations of the Birnessite $(\mathrm{c})$ and $\mathrm{Cu}^{2+} / \operatorname{Birnessite}(\mathrm{d})$. 
Raman spectra of the samples are shown in Figure 20a. The major peak at $582 \mathrm{~cm}^{-1}$ corresponds to the $v_{3}(\mathrm{Mn}-\mathrm{O})$ stretching vibration in the basal plane of the $\mathrm{MnO}_{6}$ sheets [143], which is slightly shifted in the case of $\mathrm{Cu}^{2+} /$ Birnessite to $580 \mathrm{~cm}^{-1}$. It correlates with interlayer distance changes as observed in XRD results (Figure 19b). Further six peaks at 285, 411, 478, 513 and $640 \mathrm{~cm}^{-1}$ can be obtained for both samples which are correlating well with typical Raman shifts of birnessite found in the literature [144]. Notably, when a copper cation being present in the interlayer structure of $\mathrm{Cu}^{2+} /$ Birnessite, the intensity of the peak positioned at $565 \mathrm{~cm}^{-1}$ is significantly decreased $[49,145]$. Furthermore, in the case of the $\mathrm{Cu}^{2+}$-ion intercalated birnessite, a peak was observed at $697 \mathrm{~cm}^{-1}$ correspondings to the out-of-plane symmetric stretching of $\mathrm{Mn}-\mathrm{O}$ of $\mathrm{MnO}_{6}$, which could be attributed to changes of $\mathrm{Mn}^{4+} / \mathrm{Mn}^{3+}$ ratio in the birnessite structure. The disordering of the octahedral sheets when $\mathrm{Cu}^{2+}$-ions are integrated into the interlayer space, which is an illustration of the cryptomelane structure forming [146].

Energy-dispersive X-ray spectra of birnessite showed in Figure 20b. The atomic percentage of oxygen is about 73-75 at\%, manganese content is around 18 at $\%$ and the interlayer cationic content (including potassium for Birnessite and copper/potassium for $\mathrm{Cu}^{2+} /$ Birnessite) is about 3-7 at\% for both samples, which is similar to typical birnessites [147]. The calculated formula is $\mathrm{K}_{0.18} \mathrm{MnO}_{2}{ }^{*} \mathrm{xH}_{2} \mathrm{O}$ for the Birnessite sample, and $\mathrm{Cu}_{0.20} \mathrm{~K}_{0.15} \mathrm{MnO}_{2}{ }^{*} \mathrm{xH}_{2} \mathrm{O}$ for the $\mathrm{Cu}^{2+} /$ Birnessite sample, respectively [148] based on the molar ratio detected from the quantitative analysis showed in Table 5.
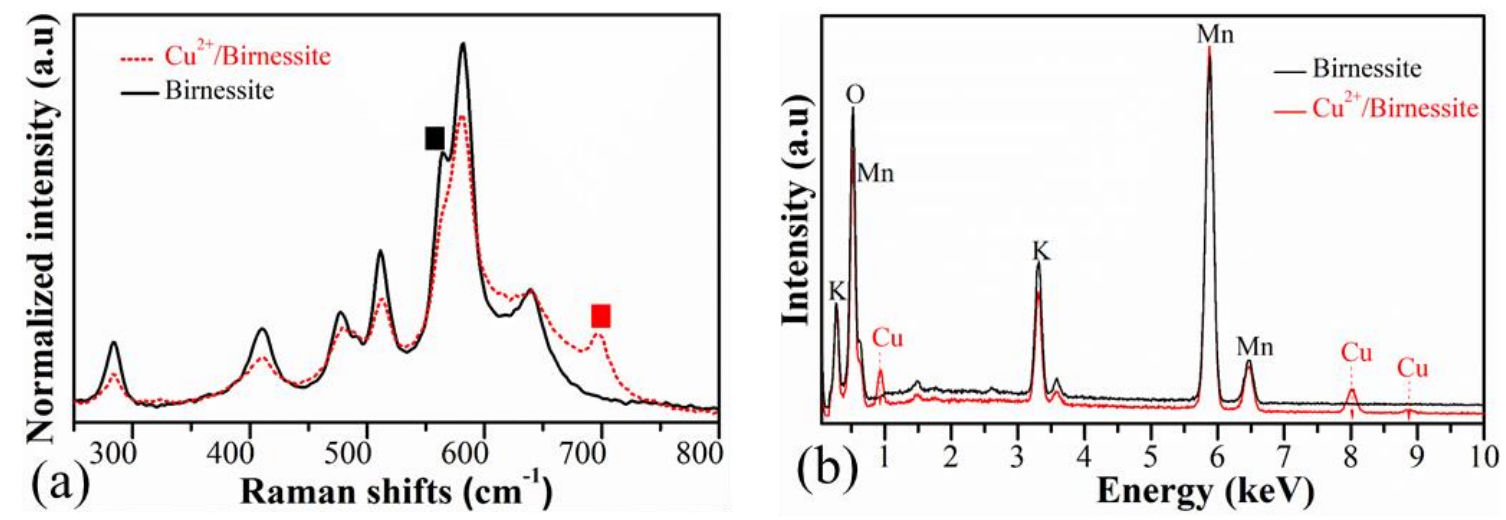

Figure 20. Raman spectra (a) Birnessite $\square 565 \mathrm{~cm}^{-1}$ (in-plane stretch) $₫ 697 \mathrm{~cm}^{-1}$ (out-of-plane stretch), and EDS spectra (b) of the pristine birnessite as well as the copper-ion intercalated birnessite structure. 
Table 5. The chemical component ratio of the birnessite samples from EDS analysis

\begin{tabular}{llll}
\hline Ratio & Elements & $\begin{array}{l}\text { Birnessite } \\
\mathrm{K}_{0.18} \mathrm{MnO}_{2} * \mathrm{xH}_{2} \mathrm{O}\end{array}$ & $\begin{array}{l}\boldsymbol{C u}^{2+} / \text { Birnessite } \\
\mathrm{Cu}_{0.20} \mathrm{~K}_{0.15} \mathrm{MnO}_{2} * \mathrm{xH}_{2} \mathrm{O}\end{array}$ \\
\hline \multirow{3}{*}{ Weight percentage } & 43.9 & 42.4 \\
(wt. \%) & $\mathrm{On}$ & 49.6 & 44.9 \\
& $K$ & 6.8 & 3.2 \\
& $\mathrm{Cu}$ & - & 5.3 \\
Atomic percentage & $\mathrm{O}$ & 78 & 73 \\
(at. \%) & $\mathrm{Mn}$ & 18 & 20 \\
\multirow{3}{*}{ Molar ratio } & $K$ & 3.2 & 3 \\
& $\mathrm{Cu}$ & - & 4 \\
& $\mathrm{~K} / \mathrm{Mn}$ & 0.18 & 0.15 \\
& $\mathrm{Cu} / \mathrm{Mn}$ & - & 0.20 \\
& $\mathrm{O} / \mathrm{Mn}$ & 4.33 & 3.65 \\
\hline
\end{tabular}

\subsubsection{Morphology and surface property characterization}

Thermal analysis of the samples at RT- $750{ }^{\circ} \mathrm{C}$ in both air and nitrogen atmosphere with a heating rate of $5{ }^{\circ} \mathrm{C} / \mathrm{min}$ are depicted in Figure 21a. Thermal stability of birnessite increased significantly due to the longer ageing time and the decrease of the interlayer water molecules and the insertion of copper cations into the interlayer. The first massive decomposition appears at $120{ }^{\circ} \mathrm{C}$ with a mass loss of $10 \%$ and $6 \%$ for Birnessite and $\mathrm{Cu}^{2+} /$ Birnessite, respectively. These phenomena can be attributed to the desorption of physisorbed water and the removal of interlayer water [149]. The second decomposition occurs in 2-3 steps at $120-550{ }^{\circ} \mathrm{C}$ with a weight loss of $8 \%$ for Birnessite and $2 \%$ for $\mathrm{Cu}^{2+} /$ Birnessite, which can be attributed to the loss of lattice oxygen species. A slight weight increment of $\sim 1 \%$ occurred at about $500{ }^{\circ} \mathrm{C}$ for the $\mathrm{Cu}^{2+} /$ Birnessite corresponding to the oxidation of manganese. In the literature, weakly crystallized synthetic birnessite shows similarly slight weight gain at $500-600{ }^{\circ} \mathrm{C}$ in the thermogravimetric analysis [150]. The thermal stability of both Birnessite sample is quite high, and only $8-18 \%$ of the total weight is lost before reaching $750{ }^{\circ} \mathrm{C}$. To understand the slight weight increment in the case of $\mathrm{Cu}^{2+} /$ Birnessite at elevated temperature, TG analysis was performed also in a nitrogen atmosphere (Figure 21b). During the inert condition, no weight gain has occurred. In the case of the air-based measurements, the $\mathrm{Cu}^{2+} /$ Birnessite shows the presence of manganese oxidation from $\mathrm{Mn}^{3+}$ to $\mathrm{Mn}^{4+}$, which can be attributed to the increased amount of the $\mathrm{Mn}^{3+}$ and decreased amount of crystallization in the samples. 

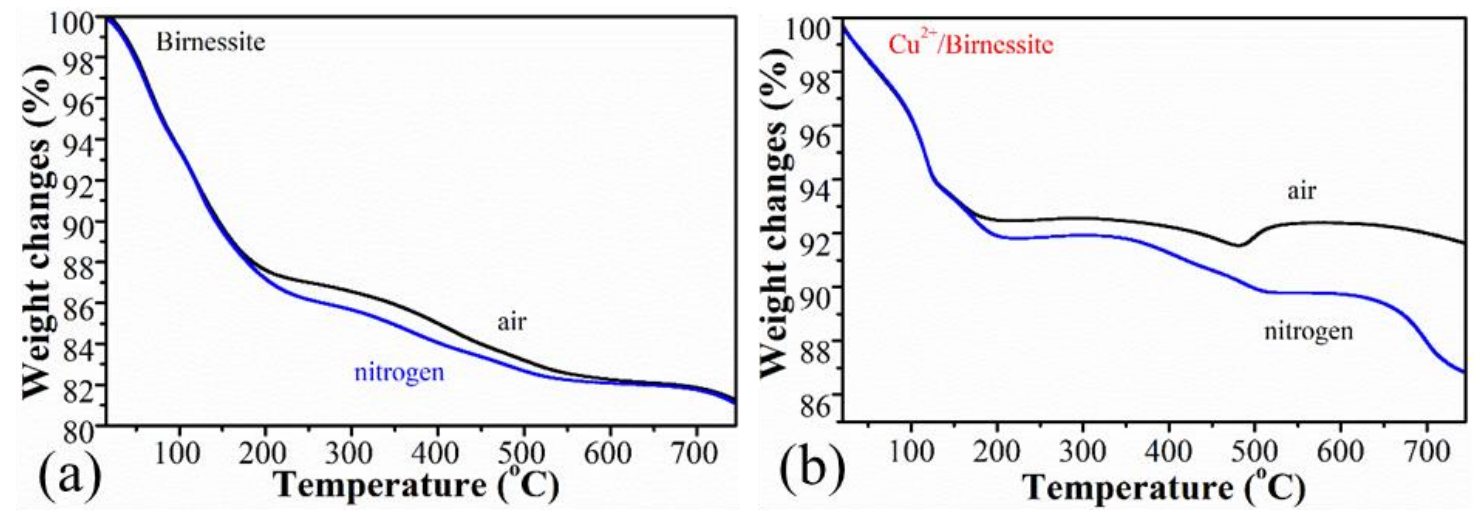

Figure 21. Thermal decomposition of a) Birnessite and b) $\mathrm{Cu}^{2+} / \mathrm{Birnessite}$ both in the air and nitrogen atmosphere at $\mathrm{RT}-750^{\circ} \mathrm{C}$ with a heating rate of $5{ }^{\circ} \mathrm{C} / \mathrm{min}$

Differential Scanning Calorimetric results are shown in Figure 22. Endothermic peaks around $100{ }^{\circ} \mathrm{C}$ and $150-350{ }^{\circ} \mathrm{C}$ refer to the dehydration of the physical and the chemically adsorbed interlayer water molecules respectively. In the case of $\mathrm{Cu}^{2+} /$ Birnessite, an exothermic peak around $500{ }^{\circ} \mathrm{C}$ was observed which corresponds to the transformation of the layered structure to the tunnel structured cryptomelane due to the oxidation of Mn (III) to Mn (IV) [151,152].

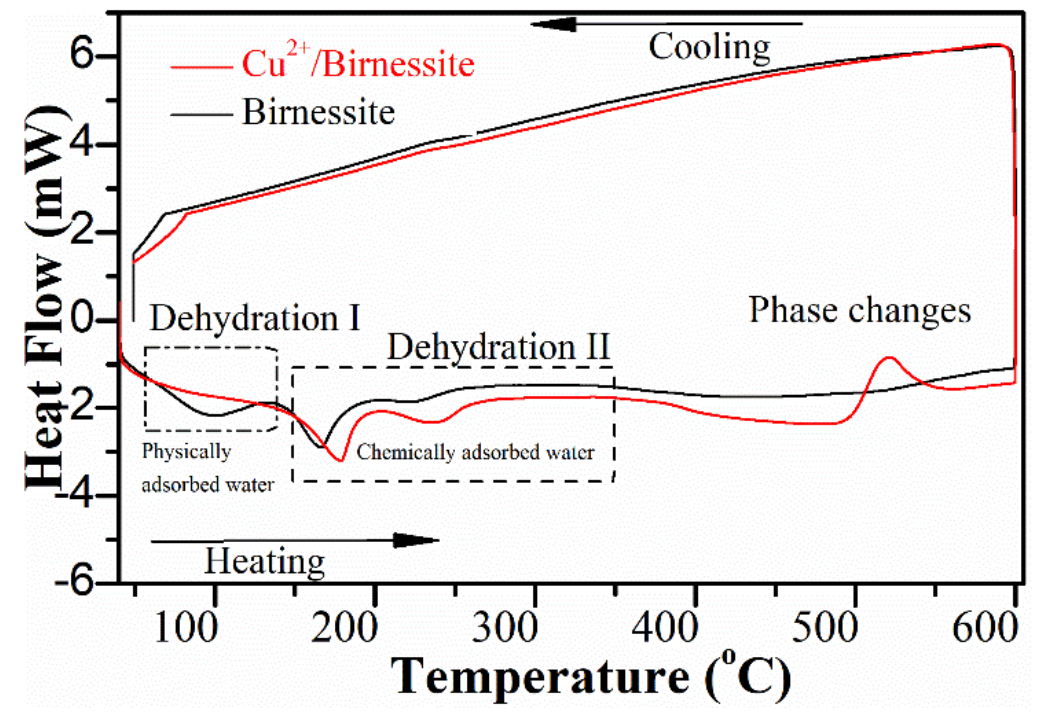

Figure 22. Differential scanning calorimetric analysis results of samples at $600{ }^{\circ} \mathrm{C}$ with heating and cooling rate $5^{\circ} \mathrm{C} / \mathrm{min}$.

$\mathbf{N}_{2}$ adsorption isotherms and pore diameter: these quantities of the samples are shown in Figure 23. Type IV $\mathrm{N}_{2}$ adsorption isotherm was observable in the case of both samples. Birnessite displays a smaller specific surface area of $21.6 \mathrm{~m}^{2} / \mathrm{g}$ compared to typical birnessites [149], while the specific surface area of $\mathrm{Cu}^{2+} /$ Birnessite was calculated to be $77.8 \mathrm{~m}^{2} / \mathrm{g}$, 
respectively in Figure 23a. As can be seen in Figure 23b, the pore diameter is $5 \mathrm{~nm}$ and 10-15 $\mathrm{nm}$ for Birnessite and $\mathrm{Cu}^{2+} /$ Birnessite, respectively showing that the copper ion modification resulted in a more mesoporous-like structure beside the increased surface area. The development of a more mesoporous-like structure for Birnessite and $\mathrm{Cu}^{2+} /$ Birnessite can be attributed to the doping of copper ion, which refines layered $\mathrm{MnO}_{2}$ nanoparticles into tiny grains, while a longer ageing process results in higher specific surface areas.

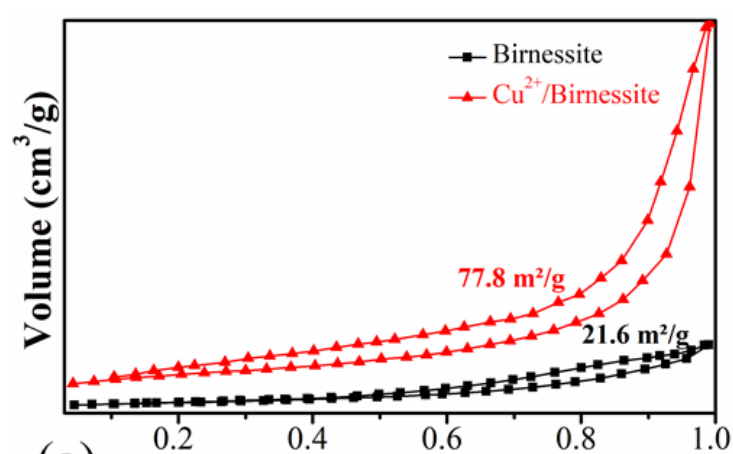

(a) Relative pressure $\left(\mathbf{P} / \mathbf{P}_{0}\right)$

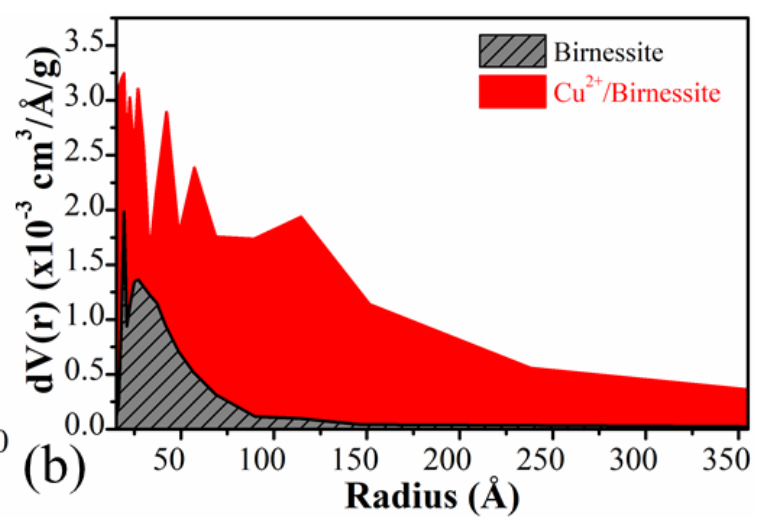

Figure 23. $\mathrm{N}_{2}$ adsorption-desorption isotherms (a), and pore diameter of the Birnessite samples (b).

The pH-dependent aggregation state and zeta potential: In water-based systems, the metal oxide particles have variable surface charges. The most critical parameters of this phenomena are the $\mathrm{pH}[153]$ and ionic strengths $[153,154]$. The $\mathrm{pH}$-dependent zeta potential $(\zeta)$ and hydrodynamic diameter $\left(\mathrm{Z}_{\mathrm{AVE}}\right)$ of the original Birnessite particles, as well as the effect of $\mathrm{Cu}^{2+}$-ion additions on the surface charges and the aggregation state of the birnessites, are shown in Figure 24. The surfaces of the Birnessite particles become charged in water due to the reactions of their surface hydroxyl groups ( $\equiv \mathrm{Mn}-\mathrm{OH})$, controlled by both the $\mathrm{pH}$ and the ionic strengths of the medium [155]. The protonation/deprotonation reactions of $(\equiv \mathrm{Mn}-\mathrm{OH})$ sites lead to the formation of positive $\left(\equiv \mathrm{Mn}-\mathrm{OH}_{2}{ }^{+}\right)$or negative $\left(\equiv \mathrm{Mn}-\mathrm{O}^{-}\right)$surface charges. The $\mathrm{pH}$ is at $\sim 2.5$ for Birnessite particles at the isoelectric point (I.E.P.), where $\zeta=0 \mathrm{mV}$, which is in good agreement with previously published measurement [155]. Around this $\mathrm{pH}$ value, the particles are aggregating $\left(\mathrm{Z}_{\mathrm{AVE}}>1000 \mathrm{~nm}\right)$ because of the lack of electrostatic stabilization. Due to the presence of ( $\equiv \mathrm{Mn}-$ $\mathrm{O}^{-}$) surface groups, colloidally stable dispersion can be observed at $\mathrm{pH}$ values between 4-10, accompanied by a low $Z_{\mathrm{AVE}}$ and high absolute value of $\zeta$ (see Figure 24a.). A large amount of $\mathrm{Na}^{+}$-ion $\left(\sim 100 \mathrm{mmol} \mathrm{L}^{-1}\right)$ added into the system as $\mathrm{NaOH}$ solution to set the $\mathrm{pH}$ around 13 , which results in the so-called screen effect. The success of the dispersion process was confirmed by the $\sim 200 \mathrm{~nm}$ measured $\mathrm{Z}_{\mathrm{AVE}}$ value in the temporarily stable regime, which is very close to the lower value of the particle size determined by SEM. 
The I.E.P. of $\mathrm{Cu}^{2+} /$ Birnessite is shifted from $\mathrm{pH} 2.5$ to $\mathrm{pH} \sim 3.5$ (see Figure 24b). The addition of $\mathrm{Cu}$ ions can lead to several chemical alterations in the mixture. First, the intercalated $\mathrm{K}$ ions can be exchanged by polyvalent $\mathrm{Cu}$ cations (justified by the lattice distance changes determined by XRD). The charge of cations can modulate the oxidative state of the manganese in the layer, namely, they are partially converted from the stable $\mathrm{Mn}^{4+}$ to $\mathrm{Mn}^{3+}$ (proved by Raman spectroscopy, TG, EDS). This phenomenon affects the surface charge properties due to the shift of the ( $\equiv \mathrm{Mn}-\mathrm{OH})$ groups' $\mathrm{pH}$. Secondly, a small part of the added $\mathrm{Cu}$ ions could form an oxide/hydroxide nanoparticle. These nanoparticles have their surface functional groups ( $\equiv \mathrm{S}-\mathrm{OH}$ ) with representative protonation/deprotonation equilibrium. Based on the literature, the I.E.P. of copper-oxide nanoparticles is about $\mathrm{pH} \sim 6.8$ [156], so the contribution of the protonated $(\equiv \mathrm{Cu}-$ $\mathrm{OH}_{2}{ }^{+}$) surface groups ( $\mathrm{pH}>$ I.E.P.) can explain the shift of the $\zeta$ values presented in Figure $\mathbf{2 4 b}$. Furthermore, these changes result in the increase of the aggregation regime for $\mathrm{Cu}^{2+} / \mathrm{Birnessite}$ (see Figure 24c) probably due to heterogeneous coagulation.
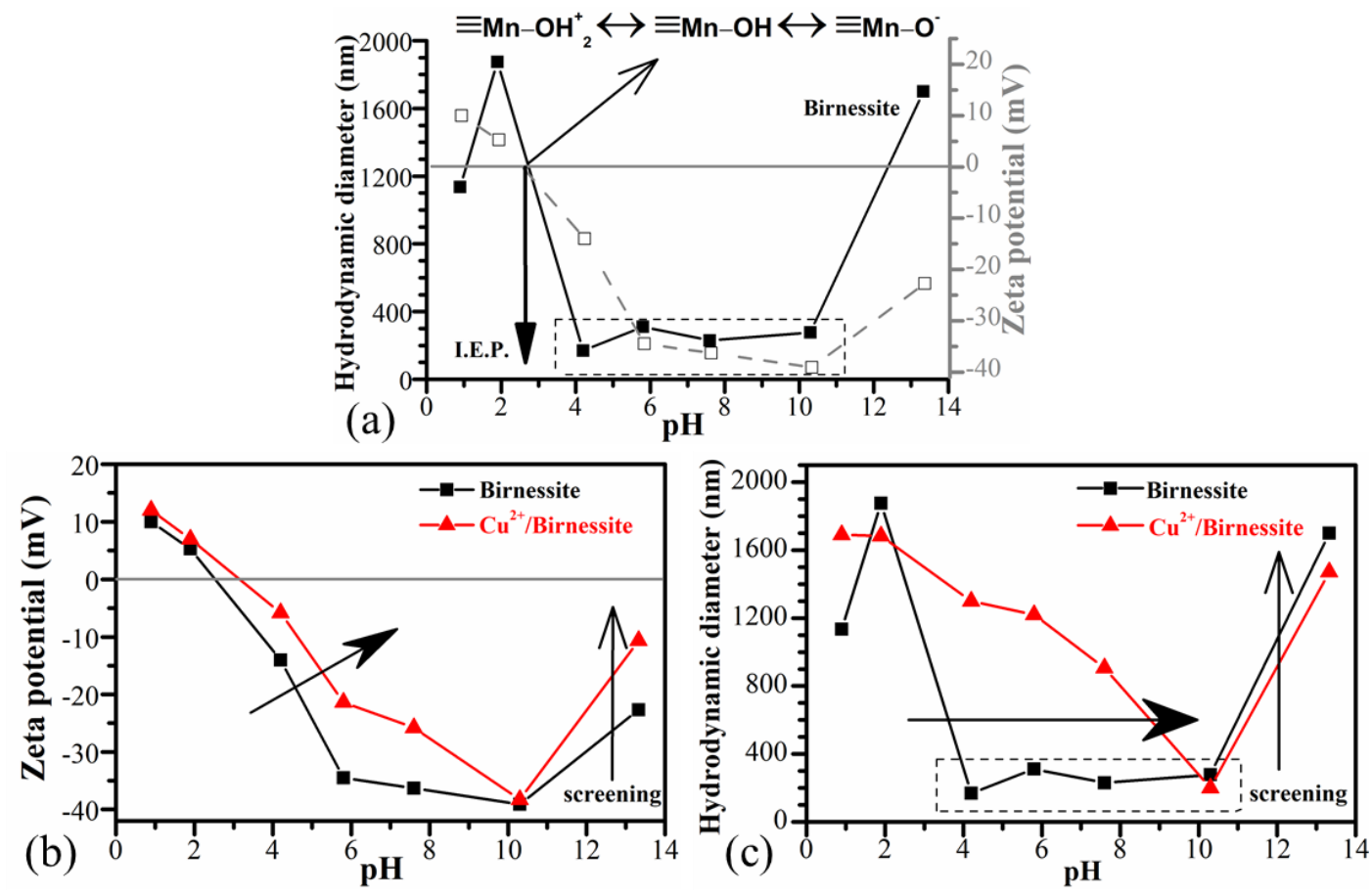

Figure 24. Characterization of the Birnessite (a) by the pH-dependent zeta potential $(\zeta)$ and hydrodynamic diameter $\left(\mathrm{Z}_{\mathrm{AVE}}\right)$ at $10 \mathrm{mmol} \mathrm{L}^{-1} \mathrm{NaCl}$. Effect of $\mathrm{Cu}$ ion addition on (b) the zeta potential and (c) the hydrodynamic diameter of the Birnessites particles at $10 \mathrm{mmol} \mathrm{L}^{-1} \mathrm{NaCl}$.

According to the $\zeta$ measurements, we could improve and prepare samples with the best parameters for the ORR investigations. As seen in $\zeta$ results, the Birnessite particles are aggregated in alkaline conditions, so the usage of carbon black during the preparation of the electrodes for ORR measurements is necessary to get an appropriate layer under the condition of ORR experiments. 
Scanning electron microscopic images showed that the birnessite consists of larger wellcrystallized plates (sheet-like) with length from $100 \mathrm{~nm}$ to a few micrometers (Figure 25a). In the case of $\mathrm{Cu}^{2+} /$ Birnessite due to copper intercalation and longer ageing process, the sheets are smaller, and aggregated miniature sheets were formed with rod-like wires (Figure 25b). Transmission electron microscopic images of the samples (Figure 25c-d) show similar morphological structures as images made by the SEM. HRTEM images (Figure 25e-f) reveal that the leading lattice distance of the Birnessite was $0.69 \mathrm{~nm}$ while it was measured to be $0.70 \mathrm{~nm}$ in the case of $\mathrm{Cu}^{2+} /$ Birnessite pointing to the presence of a slight interlayer distance expansion due to the presence of $\mathrm{Cu}^{2+}$-ions. These results correlate with results obtained by XRD (Figure 19b). The morphology of these samples is similar to the typical birnessite structures as published in the literature [157].
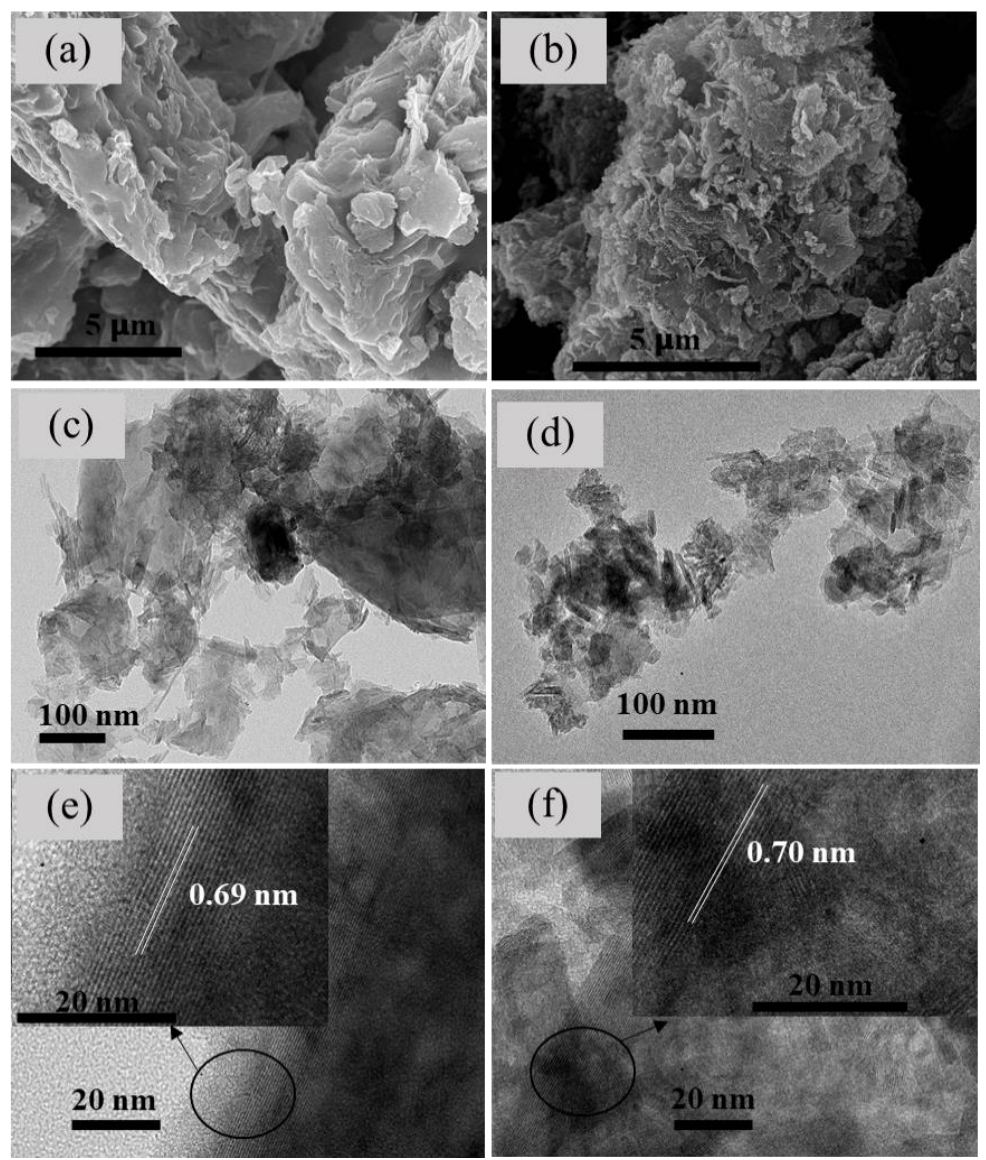

Figure 25. Typical SEM images (a-b) and TEM images (c-d), and HR-TEM images of the birnessite samples (e-f). The images created from undoped Birnessite samples on the left $(\mathrm{a}, \mathrm{c}, \mathrm{e})$ and $\mathrm{Cu}^{2+} / \mathrm{Birnessite}$ samples on the right $(b, d, f)$.

\subsubsection{Characterization results of the ball-milled manganese oxides}

\subsubsection{Mechanochemical synthesis and energy calculation}

The high-energy ball milling process is presented in Figure 26a. Also, milling-map of samples milled with different rotation speeds 200rpm (M200), 450rpm (M450), and 600rpm 
(M600) was shown in Figure 26b, where the ball-impact energies $\left(\mathrm{E}_{\mathrm{b}}\right)[158,159]$ and cumulative energies $\left(\mathrm{E}_{\text {cum }}\right)$ are calculated by equation (15) and (16), respectively [158-162]. This model allows the calculation of the impact energy of a single ball hit as well as the amount of the total energy transferred to the milled material during the process. By comparing results from a simple statistical model with those of the "Burgio-Rojac model" [159] we were able to demonstrate that the latter provides a more appropriate framework for the interpretation of milling-induced changes in the different oxidation state manganese-oxide.

$$
\Delta E_{\mathrm{b}}^{*}=\frac{1}{2} \cdot \varphi_{\mathrm{b}} \cdot K_{\mathrm{a}} \cdot\left(\rho_{\mathrm{b}} \frac{\pi d_{\mathrm{b}}^{3}}{6}\right) \cdot W_{\mathrm{p}}^{2}\left(\left(\frac{W_{\mathrm{v}}}{W_{\mathrm{p}}}\right)^{2}\left(\frac{D_{\mathrm{v}}-d_{\mathrm{b}}}{2}\right)^{2} \cdot\left(1-2 \frac{W_{\mathrm{v}}}{W_{\mathrm{p}}}\right)-2 R_{\mathrm{p}}\left(\frac{W_{\mathrm{v}}}{W_{\mathrm{p}}}\right) \cdot\left(\frac{D_{\mathrm{v}}-d_{\mathrm{b}}}{2}\right)-\left(\frac{W_{\mathrm{v}}}{W_{\mathrm{p}}}\right)^{2}\left(\frac{D_{\mathrm{v}}-d_{\mathrm{b}}}{2}\right)^{2}\right)
$$

, where " $K$ " is the constant of the mill, " $\varphi$ " is the obstruction coefficient and the other variables are the geometrical parameters of the mill and the milling drum. By modifying this equation (15) with the frequency of the impacts $(v)$, the milling time $(t)$ and the measured material's mass $\left(m_{p}\right)$, the cumulative energy $\left(E_{\text {cum }}\right)$ equation (16) can be calculated. It shows the energy value that is given off to one gram of milled material.

$$
E_{\text {cum }}=\left(\Delta E_{\mathrm{b}}^{*} \cdot v_{\mathrm{t}} \cdot t\right) / m_{\mathrm{p}}
$$

By using the calculated $E_{b}$ and $E_{\text {cum }}$ energies, milling-maps were made, to illustrate the changes in each sample (M200, M450 and M600). As shown in Figure 26b, due to rotation speed increases the ball impact energy $\left(E_{b}\right)$ and cumulative energy $\left(E_{c u m}\right)$ both increased by a certain amount, which affects the crystal structure and physical-chemical properties of the samples.
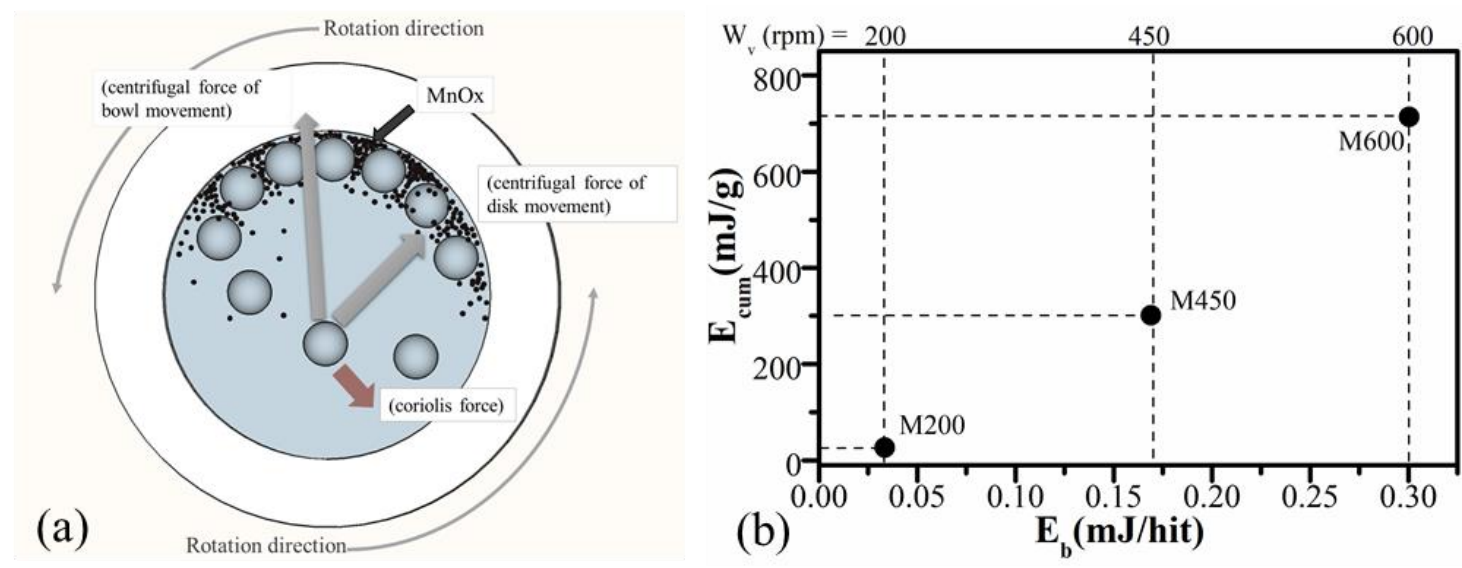

Figure 26. Schematic view of the motion of the ball and powder mixture in the high-energy ball milling process (a) and milling-map of samples, displaying the grounding process with different ball-impact $\left(\mathrm{E}_{\mathrm{b}}\right)$ and cumulative energy $\left(\mathrm{E}_{\text {cum }}\right)$ which is dependent on the rotational speed $\left(\mathrm{W}_{\mathrm{v}}\right)(\mathrm{b})$. All the samples were milled for 4 hours. 


\subsubsection{Structural determination and chemical characterization}

Figure 27a shows $X$-ray diffraction patterns of the milled samples. The main reflection peaks of the sample milled at $200 \mathrm{rpm}$ (M200) are at $12.4^{\circ}, 25.1^{\circ}, 36.9^{\circ}$ and $65.4^{\circ}$, which correspond to birnessite type $\sigma-\mathrm{MnO}_{2}$ (JCPDS 421317) $[163,164]$. The reflection peaks of the sample milled at $450 \mathrm{rpm}(\mathrm{M} 450)$ are at $12.4^{\circ}, 25.3^{\circ}, 36.5^{\circ}, 44.6^{\circ}$ and $65.4^{\circ}$ and they also correspond to the birnessite type $\sigma-\mathrm{MnO}_{2}$ (JCPDS 421317) [165], except $44.6^{\circ}$ which matches with hausmannite-type amorphous $\mathrm{Mn}_{3} \mathrm{O}_{4}$ (JCPDS 011127) [166]. The sample milled at $600 \mathrm{rpm}$ (M600) showed only three major reflection peaks at $36.2^{\circ}, 44.6^{\circ}$ and $64.6^{\circ}$, which peaks are matched with amorphous $\mathrm{Mn}_{3} \mathrm{O}_{4}$ (JCPDS 011127) [166,167]. The crystal structure tuned by birnessite type manganese (IV) oxide (M200) reduces to manganese (III and II) oxides in the case of M450 and M600 samples under alkaline conditions during the milling process. As the rotation speed increases, the energies $\left(\mathrm{E}_{\mathrm{b}}\right.$ and $\left.\mathrm{E}_{\mathrm{cum}}\right)$ increase as well and the temperature rises slightly inside the milling chamber. Consequently, the interlayer water is partially released, which weakens the layered structure.

Figure 27b shows the Raman spectra of the samples, where the characteristic Raman shifts of the Mn-O symmetric stretching vibration at $647 \mathrm{~cm}^{-1}$ could be observed for all three manganese oxides. The shift at $575 \mathrm{~cm}^{-1}$ originates from the Mn-O symmetric stretching vibration in the basal plane of $\left[\mathrm{MnO}_{6}\right]$ sheets of birnessite, and it is dependent on the presence of $\mathrm{Mn}^{4+}$ ions in sample M200 and M450, respectively [168]. In the case of M600, which is an amorphous hausmannite type manganese oxide [144], the Raman shift at $575 \mathrm{~cm}^{-1}$ is absent due to the total transformation of $\mathrm{Mn}(\mathrm{IV})$ into $\mathrm{Mn}^{3+}$ and $\mathrm{Mn}^{2+}$ ions in the structure.
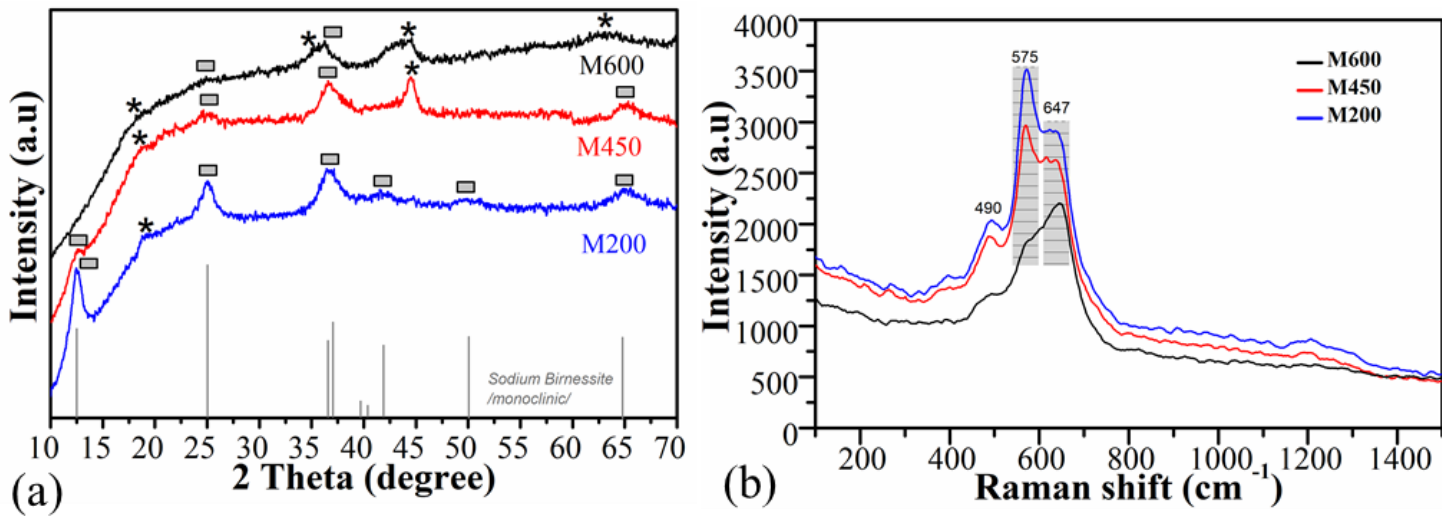

Figure 27. X-ray diffraction patterns of the pure samples (a) $\left\{*\right.$ birnessite type $\sigma-\mathrm{MnO}_{2}, \boldsymbol{\nabla} \mathrm{Mn}_{3} \mathrm{O}_{4}$ phase \}and Raman spectra of samples (b).

X-ray diffraction patterns of the metal $(\mathrm{Pt}$ and $\mathrm{Cu})$ doped samples and their Raman shifts are shown in Figure 28. No additional peaks were observed in the doped samples for both measurements, which illustrates that loading during the milling process does not alter the original crystal structure of the manganese oxides. One thing to note for Raman spectra in Figure 28d: 
the ratio of the Mn-O liberal stretching and the Mn-O basal plane stretching of the M200 samples are slightly fluctuating due to the $\mathrm{Pt}$ or $\mathrm{Cu}$ atoms in their structure.
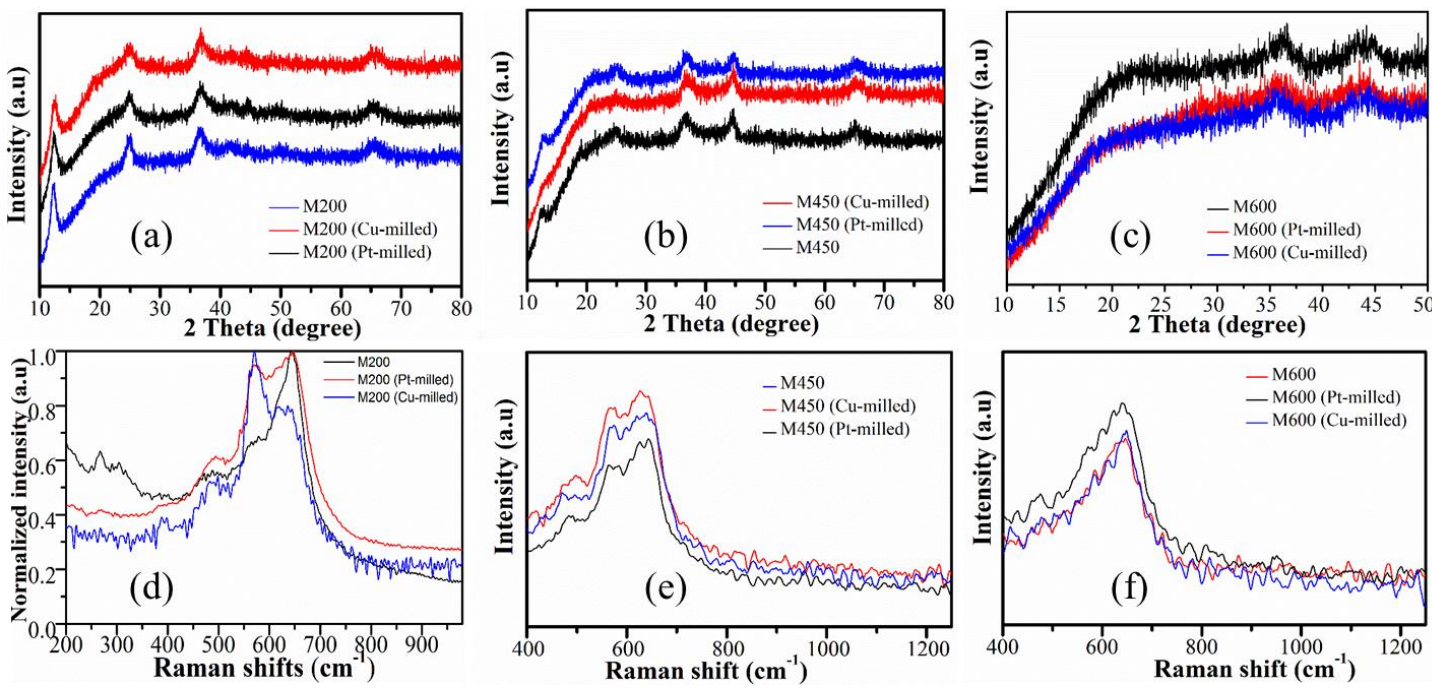

Figure 28. X-ray diffraction patterns of the metal ( $\mathrm{Pt}$ and $\mathrm{Cu}$ ) doped samples (a-c) and their Raman shifts(d-f).

The Energy-dispersive X-ray spectroscopic elemental analysis results are summarized in

Table 6. The EDS spectra reveal that the samples consisted of oxygen, manganese, potassium, sodium, and doped metal elements only, and no impurities from the milling bowl and balls can be found. The sodium and potassium contents were decreased from 0.9 atomic percentage (at $\%$ ) and 6.51 (at \%) to 0.11 (at \%) and 2.64 (at \%), respectively as the milling speed was increased from $200 \mathrm{rpm}$ to $600 \mathrm{rpm}$. The presence of Pt-dopant resulted in a $\sim 4$ times higher sodium and potassium content for the Pt-doped M600 sample compared to the pure M600. Also, a similar trend showed in the case of $\mathrm{Cu}$ doping. The weight percentage of the Pt in M600 (Pt-milled) was $\sim 3$ (wt.\%) proving the Pt atoms were fully incorporated into the structures confirmed the weight ratio from the precursors (Table 6 )

Table 6. Composition of the manganese oxide catalysts evaluated from SEM-EDS data.

\begin{tabular}{|c|c|c|c|c|c|c|c|c|c|c|c|c|}
\hline \multirow[t]{2}{*}{ Sample } & \multicolumn{6}{|c|}{ Composition (at. \% ) } & \multicolumn{6}{|c|}{ Composition wt.\% } \\
\hline & $\mathrm{Mn}$ & $\mathrm{K}$ & $\mathrm{O}$ & $\mathrm{Na}$ & $\mathbf{P t}$ & $\mathbf{C u}$ & Mn & $\mathrm{K}$ & $\mathrm{O}$ & $\mathrm{Na}$ & $\mathbf{P t}$ & $\mathbf{C u}$ \\
\hline M200 & 27.77 & 0.90 & 64.81 & 6.51 & - & & 55.53 & 1.28 & 37.74 & 5.45 & - & - \\
\hline M450 & 21.90 & 0.29 & 73.32 & 4.49 & - & & 48.31 & 0.46 & 47.09 & 4.14 & - & - \\
\hline M600 & 16.80 & 0.11 & 80.46 & 2.64 & - & & 40.56 & 0.18 & 56.59 & 2.67 & - & - \\
\hline $\begin{array}{l}\text { M600 } \\
\text { (Pt-milled) }\end{array}$ & 19.11 & 0.51 & 71.28 & 8.70 & 0.39 & - & 42.21 & 0.80 & 45.86 & 8.04 & 3.09 & - \\
\hline $\begin{array}{l}\text { M600 } \\
(\mathrm{Cu}- \\
\text { milled) }\end{array}$ & 18.60 & 0.36 & 74.32 & 6.07 & - & 0.5 & 42.60 & 0.59 & 49.45 & 5.81 & - & 1.55 \\
\hline
\end{tabular}




\subsubsection{Morphology and surface property characterization}

Figure 29a displays the results of the specific surface area measurements. The surface area of the sample was dependent on the milling speed, and it is increased from $11 \mathrm{~m}^{2} / \mathrm{g}$ to 150 $\mathrm{m}^{2} / \mathrm{g}$ for M200 and both M450, M600, respectively presented in Table 7. M200 had mostly micropores, while M450 and M600 were mesoporous with an average pore radius of $\sim 6 \mathrm{~nm}$ (Figure 29b). Manganese-oxides milled at higher milling speed (M450 and M600) presented a higher average specific surface area than manganese-oxide nanoparticles observed in the literature $[169,170]$. No significant difference was observed in metal $(\mathrm{Pt}, \mathrm{Cu})$ loaded samples.

Table 7. Specific surface area results of the ball-milled manganese-oxide samples

\begin{tabular}{cccc}
\hline Samples & Specific surface area $\mathrm{m}^{2} / \mathrm{g}$ & Pore radius, $\mathrm{nm}$ & Pore volume, $\mathrm{cc} / \mathrm{g}$ \\
\hline M200 & 11 & $<2$ & 0.06 \\
M450 & 159 & $>5.7$ & 0.7 \\
M600 & 159 & $>5.8$ & 0.6 \\
\hline
\end{tabular}
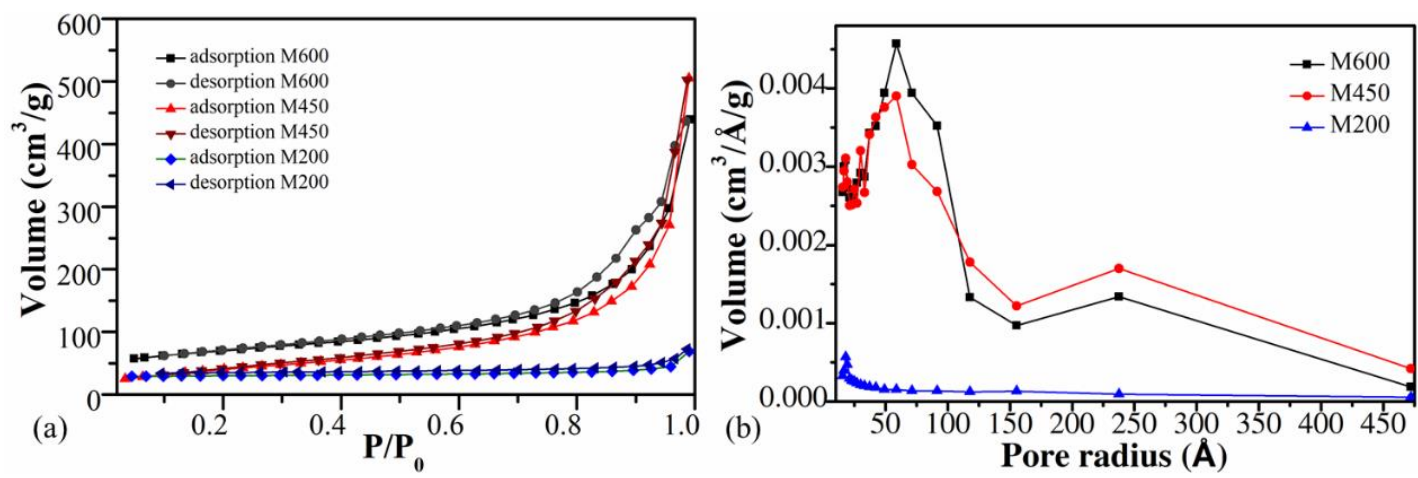

Figure 29. $\mathrm{N}_{2}$ adsorption analysis full isotherm (a) and the pore radius of the pure samples calculated from BET evaluation of $\mathrm{N}_{2}$ adsorption-desorption isotherms (b).

Figure 30a reveals that the thermogravimetric analysis result of the samples in the air. The main thermal changes in M200 and M450 samples are both like the typical synthetic birnessite. During the first decomposition step at RT $-110{ }^{\circ} \mathrm{C}$ with a weight loss of $\sim 6 \%$ caused by the release of physically adsorbed water [149]. The second weight loss of $\sim 2 \%$ resulted at 220 ${ }^{\circ} \mathrm{C}$ stemming from the release of physically adsorbed water from the interlayer spacing [171]. The third weight loss occurred at $500{ }^{\circ} \mathrm{C}$ and $570{ }^{\circ} \mathrm{C}$ for M200 and M450 respectively, which corresponds to the reduction of $\mathrm{Mn}(\mathrm{IV})$ to $\mathrm{Mn}$ (III, II) and the formation of $\mathrm{Mn}_{2} \mathrm{O}_{3}$ [172]. The fourth change occurred around $550{ }^{\circ} \mathrm{C}$ and $630^{\circ} \mathrm{C}$ for M200 and M450, respectively, where $1 \%$ of weight gained due to the slow re-oxidation of the manganese $\mathrm{Mn}_{3} \mathrm{O}_{4}$ to $\mathrm{Mn}_{2} \mathrm{O}_{3}$ and $\alpha-\mathrm{MnO}_{2}$ [173,174]. It is interesting to note, that only in the case of the M200 sample, a fifth thermal change occurred where the rest of the $\mathrm{Mn}_{2} \mathrm{O}_{3}$ reduced to $\mathrm{Mn}_{3} \mathrm{O}_{4}$ at $680{ }^{\circ} \mathrm{C}$ [175]. On the other hand, the thermal decomposition behaviour was quite different for the M600 sample due to the presence of $\mathrm{Mn}$ (II, III)-oxide phases. The first decomposition occurred at $110{ }^{\circ} \mathrm{C}$ with a $\sim 4 \mathrm{wt} \%$ weight loss, 
which corresponds to the release of physically adsorbed water. The second change occurred with $\sim 1 \%$ weight gain at $200{ }^{\circ} \mathrm{C}$ possibly stemming from the oxidation of manganese and phase change of $\mathrm{Mn}_{3} \mathrm{O}_{4}$ to $\mathrm{Mn}_{2} \mathrm{O}_{3}$ [173]. The third change was a weight loss of $\sim 2 \%$ due to the reduction of $\mathrm{Mn}_{2} \mathrm{O}_{3}$ to $\mathrm{Mn}_{3} \mathrm{O}_{4}$ [175]. Oxidation occurred at low temperature for the M600 sample, which indicates that the amount of $\mathrm{Mn}$ (III) is much higher than the other two samples. Also demonstrates slow crystallization of the amorphous morphology [149]. Thermogravimetric analysis result of the samples in nitrogen disclosed in Figure 30b. No weight loss or gain occurred at $300{ }^{\circ} \mathrm{C}-550$ ${ }^{\circ} \mathrm{C}$ for the M600 sample in nitrogen flow helping to prove the results and discussion about the thermal analysis under air.

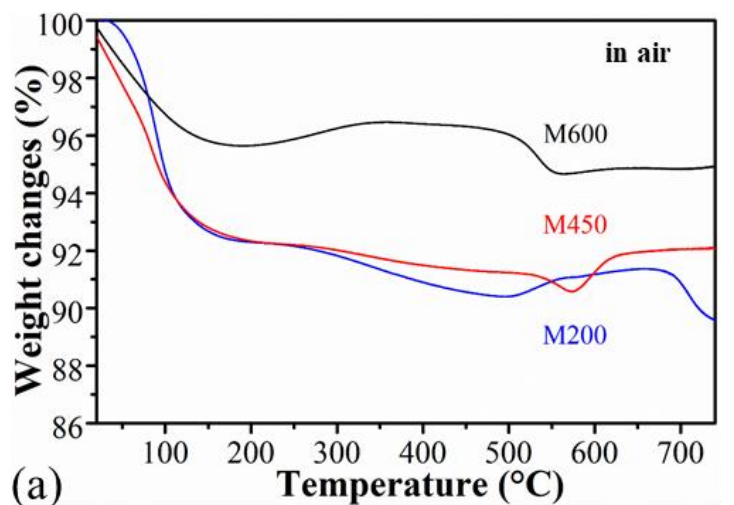

(a)

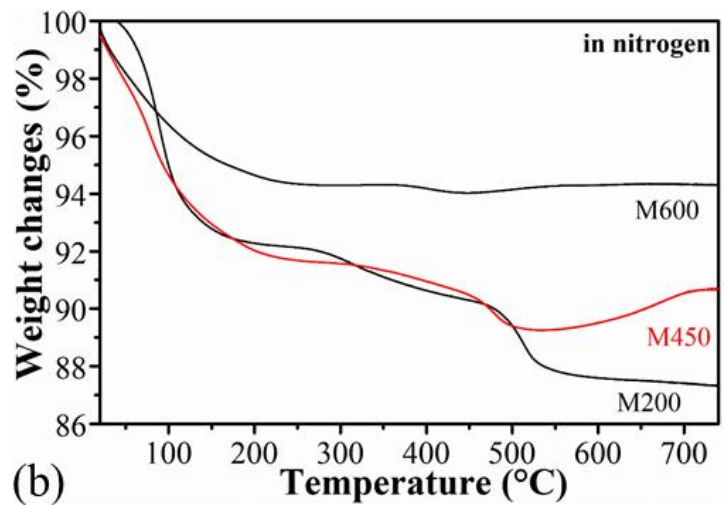

(b)

Figure 30. Thermal decomposition of the pure samples at a heating rate of $5{ }^{\circ} \mathrm{C} \mathrm{min}-1$ in the air (a) and in nitrogen (b).

In Figure 31(a-c), X-ray diffraction patterns of the samples after TG analysis in both air and nitrogen atmosphere showed that $\alpha-\mathrm{MnO}_{2}$ and $\mathrm{Mn}_{3} \mathrm{O}_{4}$ oxides produced in thermal analysis in air, while only $\mathrm{Mn}_{3} \mathrm{O}_{4}$ remained for M200. In the case of the M450 sample, $\alpha-\mathrm{MnO}_{2}$ and $\mathrm{Mn}_{3} \mathrm{O}_{4}$ phase formed, compared to $\mathrm{M} 600$, where only $\mathrm{Mn}_{3} \mathrm{O}_{4}$ created under oxidative conditions. From the thermal gravimetric analysis of the samples and the X-ray diffraction patterns of the end products (after TGA), we can derive the same conclusion as from the diffraction patterns of the initial samples, such as M200 is mainly consisted of $\mathrm{MnO}_{2}$ (manganese oxidation state: +4 ), and M450 consists of $\mathrm{MnO}_{2}$ and a minor amount of $\mathrm{Mn}_{3} \mathrm{O}_{4}$ (manganese oxidation state: IV, III, II), while M600 consists of almost pure phase $\mathrm{Mn}_{3} \mathrm{O}_{4}$ (manganese oxidation state: III, II).
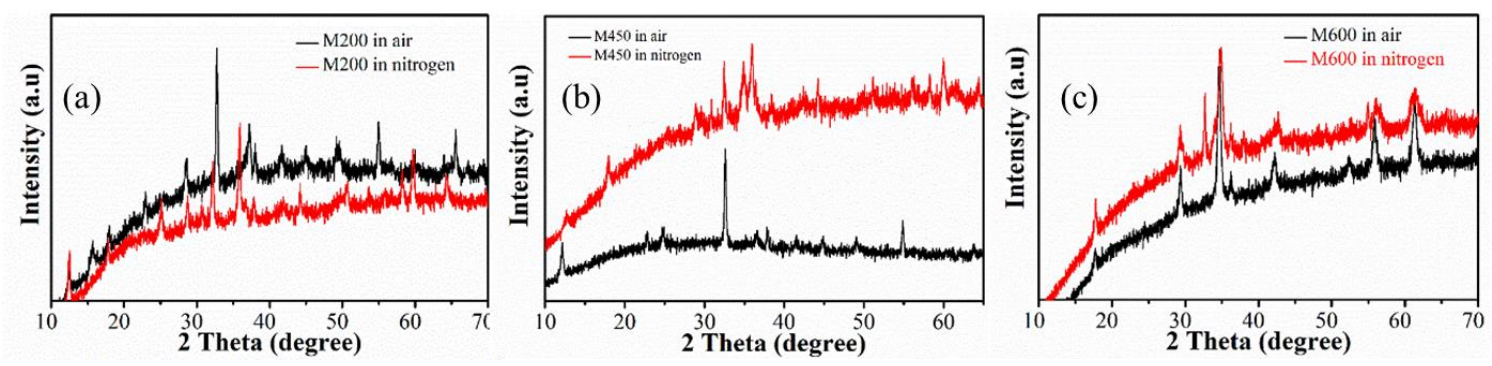

Figure 31. X-ray diffraction patterns of the samples after TGA analysis: a) M200, b) M450, and v) M600. 
Figure 32b presents the differential scanning calorimetric results of the samples. During the heating process at low-temperature $\left(150^{\circ} \mathrm{C}\right)$, endothermic peaks appear for M200 and M450 related to the dehydration of interlayer water and formation of $\mathrm{Mn}_{2} \mathrm{O}_{3}$. Endothermic peaks at higher temperatures illustrate that the reduction of the $\mathrm{Mn}$ (III) to $\mathrm{Mn}$ (II) and the possible phase transition to tunnel structured flakes of $\mathrm{Mn}_{3} \mathrm{O}_{4}$ [176]. In the case of $\mathrm{M} 600$, one endothermic peak observed around $550^{\circ} \mathrm{C}$, which illustrates the phase transition of $\mathrm{Mn}_{3} \mathrm{O}_{4}$ from an amorphous state to nanoflake-structured.

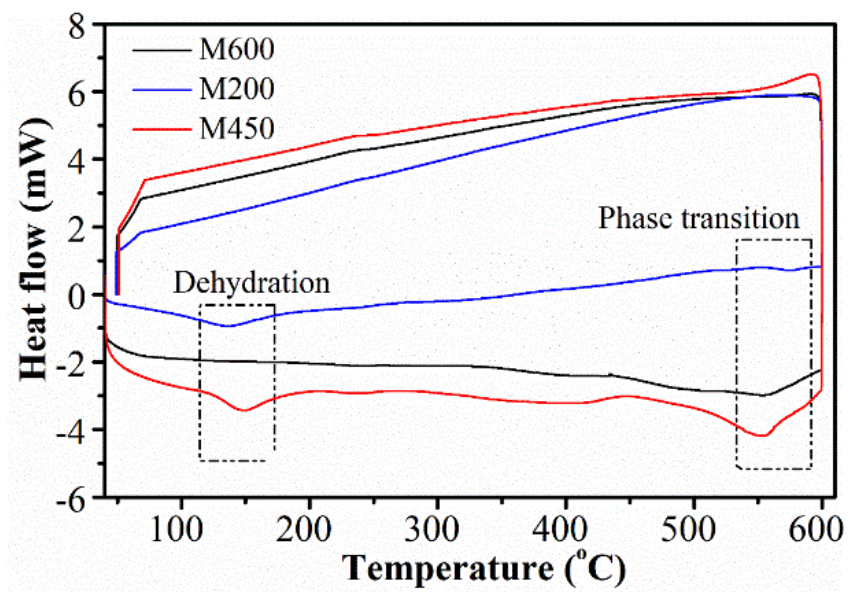

Figure 32. Differential scanning calorimetry results of the milled samples at $600{ }^{\circ} \mathrm{C}$.

Figure 33(a, c, e) and (b, d, f) show the scanning electron microscopic (SEM) and transmission electron microscopic images, respectively. With the increment of the milling speed, the average particle size also decreased. M200 sample has larger flakes and aggregated sheets identical to the typical birnessite-structure [74], while at higher milling speeds, the crystal structure was ruined due to the higher mechanical impact as well as the higher temperature resulted in the decreases of the interlayer water. Besides the fact that the average oxidation state of manganese decreased in the case of M450 and M600 samples compared to the M200 sample, the structure of the M450 consisted of a mixture of sheets and flakes and M600 consisted mostly of 10-50 nm small nanoflakes [177]. 


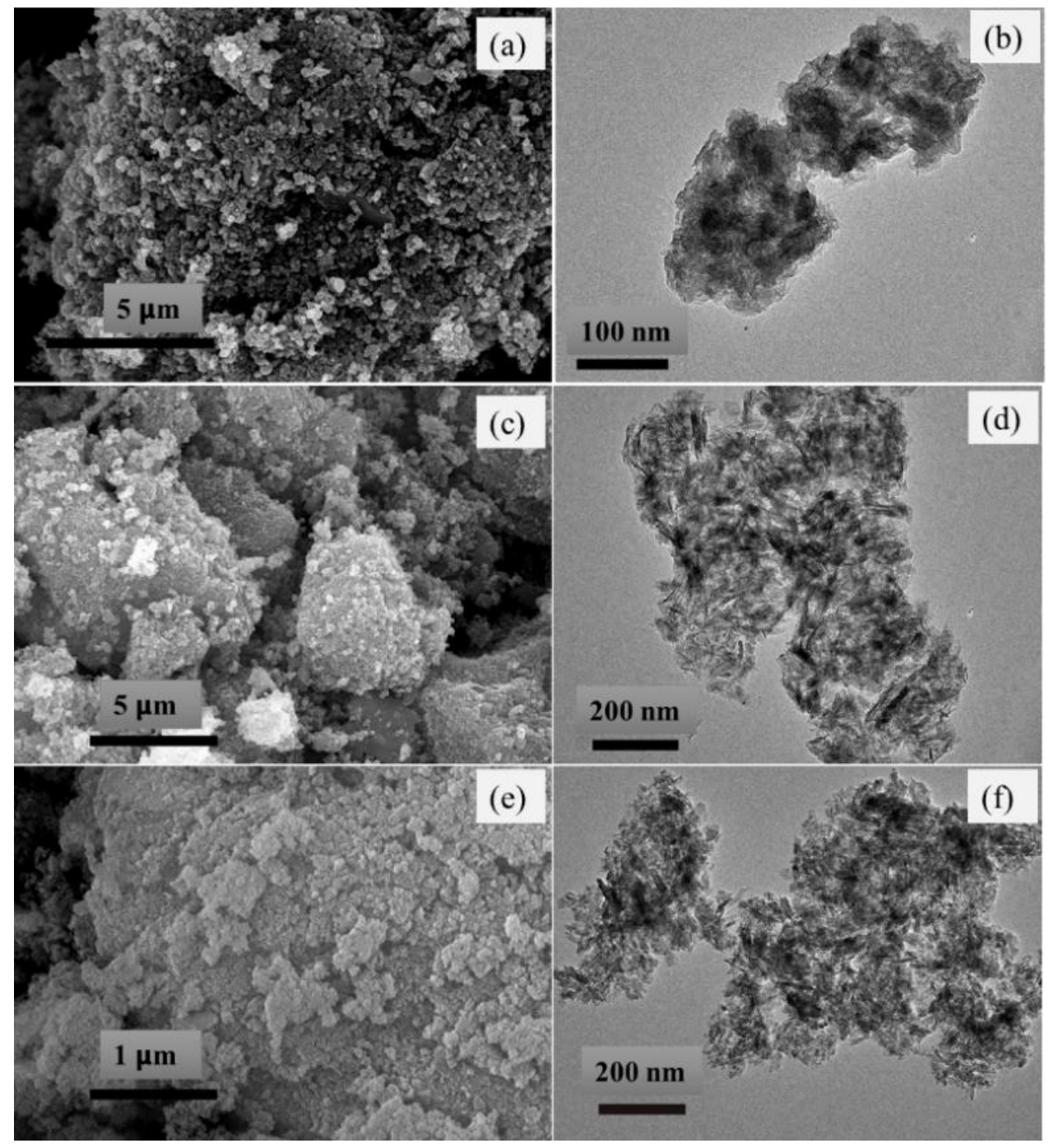

Figure 33. Scanning electron microscopic images (SEM) and Transmission electron microscopic (TEM) images of the pure samples (a-b) M200, (b-c) M450 and (e-f) M600.

\subsubsection{Characterization results of deposited manganese oxide from natural ore}

\subsubsection{Structural determination and chemical characterization}

Figure 34a displays the $\mathrm{X}$-ray diffraction patterns of the initial manganese oxide (MnOxI) and manganese mineral $\left(\mathrm{MnO}_{\mathrm{x}}-\mathrm{M}\right)$. Before and after milling, the crystal phase is not changed for both samples and the diffraction peaks at $28^{\circ}, 36^{\circ}, 43^{\circ}$, and $56^{\circ} 2 \theta$ are matching with beta $\mathrm{MnO}_{2}$ reference (JCPDS 24-0735) [178]. Due to milling and washing, silica and iron content may have decreased by some amount, which can be seen by the reduction of the diffraction peak intensity at $26^{\circ}$ [179][180]. Figure 34b shows a carbon paper (bare CP electrode) and the inset graph shows the electrochemically deposited $\left(\mathrm{MnO}_{\mathrm{x}}-\mathrm{D}\right)$ diffraction patterns. The peaks at $18^{\circ}$, $29^{\circ}, 33^{\circ}, 36^{\circ}, 38^{\circ}, 45^{\circ}, 60^{\circ}$ and $66^{\circ}$ are indexed by the crystal faces $(101,112,103,211,004$, 220, 224 and 400), which correlates with the diffraction peaks of $\mathrm{Mn}_{3} \mathrm{O}_{4}$ (JCPDS 024-0734) [181][182], except the peaks at $26^{\circ}$ and $55^{\circ}$, which are the carbon paper electrode diffractions 
peaks [183]. Figure 34c shows the Raman spectra of the MnOx-I and MnOx-M. As shown in the figure, initial manganese (MnOx-I) contains some organic residues which have a broad shift at 2000-3000 $\mathrm{cm}^{-1}$. Intense shift positions at 650 and $530 \mathrm{~cm}^{-1}$ reveal that $\mathrm{MnO}_{\mathrm{x}}-\mathrm{I}$ and $\mathrm{MnO}_{\mathrm{x}}-\mathrm{M}$ are both beta manganese oxides $\left(\beta-\mathrm{MnO}_{2}\right)$ [184]. This outcome compromises the XRD result. Additionally, the peak at $585 \mathrm{~cm}^{-1}$ illustrates that MnOx-I was containing a significant amount of layered structured delta manganese dioxide $\left(\delta-\mathrm{MnO}_{2}\right)$ phase but after the wet milling this crystal structure is decreased for MnOx-M. Figure 34d illustrates the deposition of manganese oxide on bare carbon paper electrode. As seen in the figure, no shifts detected corresponding to carbon paper which illustrates a full cover of manganese oxides on the surface. The intense peaks at 636 , 460,320 , and $290 \mathrm{~cm}^{-1}$ are corresponding to the Raman shifts of $\mathrm{Mn}_{3} \mathrm{O}_{4}$ reported in the literature [184].

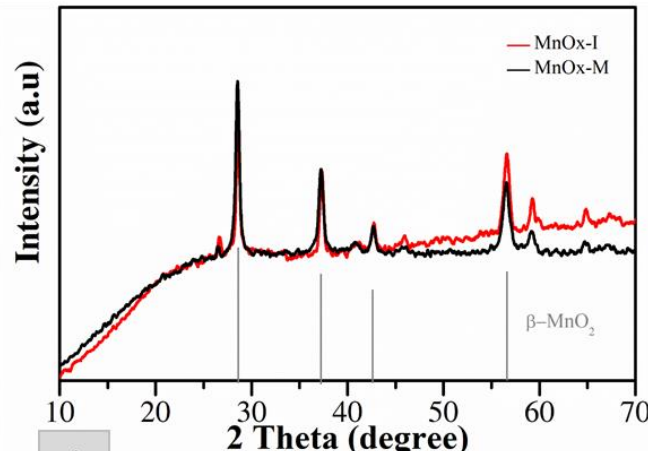

a)

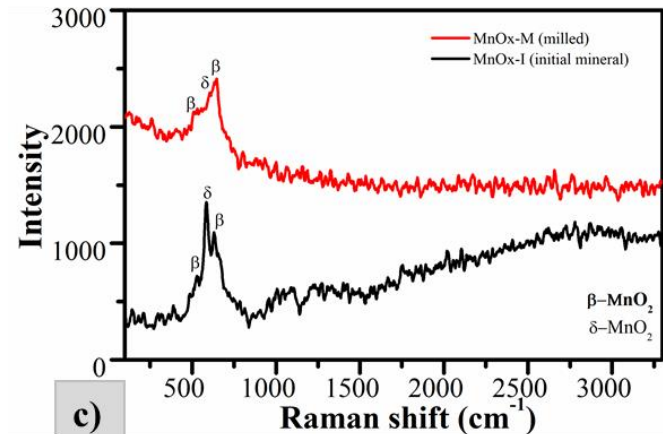

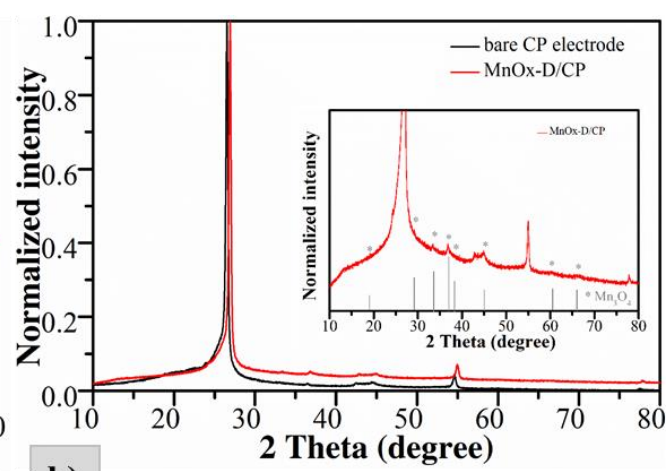

b)

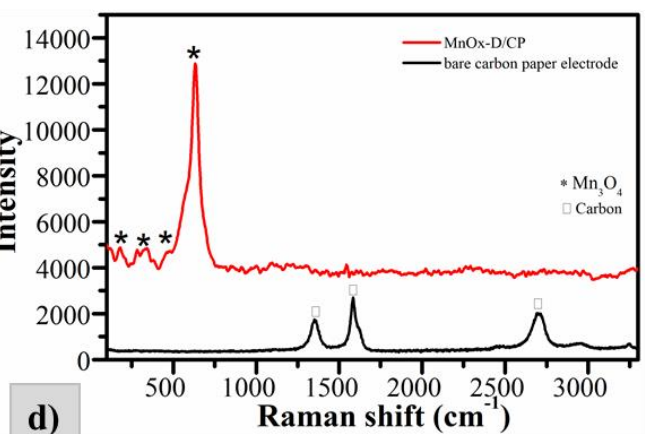

Figure 34. X-ray diffraction patterns of the MnOx-M and MnOx-I (a), and carbon paper and MnOx-D deposited on carbon paper (b), Raman spectra of the MnOx-M and MnOx-I (c), and carbon paper and MnOx-D deposited on carbon paper (d).

$\mathrm{X}$-ray electron diffraction spectroscopy (EDS) analysis data of the samples is showed in

Table 8. The original mineral sample (MnOx-I) was containing numerous impurities such as silica, aluminium, iron, sodium, potassium, magnesium, and barium. After the wet milling, impurities of the natural mineral decreased even barium and magnesium content removed but a negligible amount of chromium and nickel detected which was caused by the ball milling as can be observed in our previous work as well [185]. Figure 35a-c shows the image of the mapped area and the chemical element mapping of the MnOx-M and MnOx-D/CP. The sample which 
electrochemically deposited on carbon paper MnOx-D/CP illustrated in Figure 35d and chemical analysis proves that the impurity of the manganese mineral sample is reduced due to dissolution, filtering, electrochemical process, and washing. The manganese content of MnOx-D was higher than both the MnOx-I and MnOx-M with about $40 \mathrm{wt} . \%$ of manganese, which is almost the same as synthetic manganese oxide from chemical reagents [186][187]. As shown in Figure 35d, the deposited sample contains mostly manganese and oxygen and a small amount of iron and sodium are present.

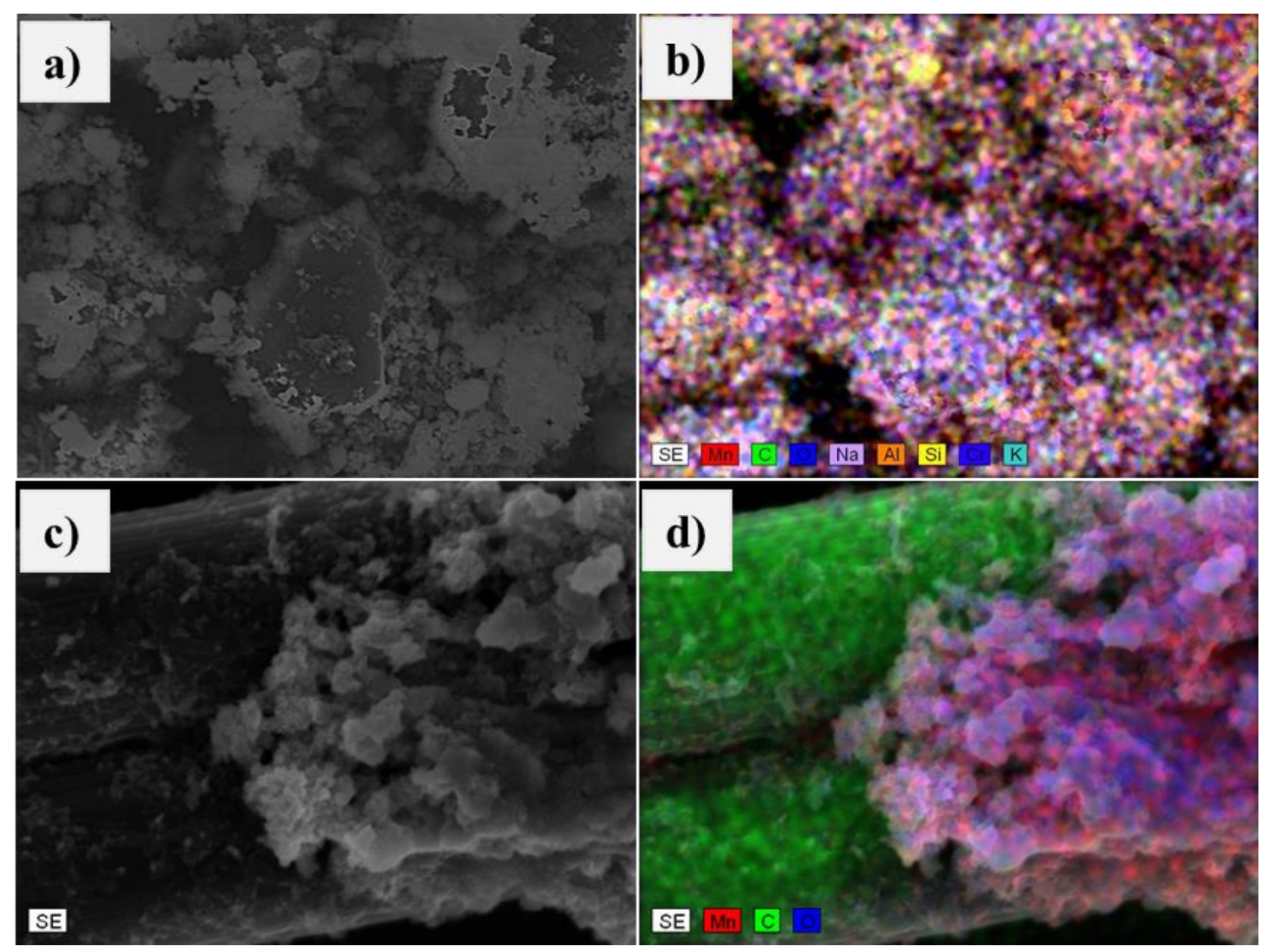

Figure 35. EDS-mapping used SE (second elementary image) of the MnOx-M (a-b) and MnOx-D deposited on carbon paper (MnOx-D/CP) (c-d).

Table 8. Quantitative chemical analysis result (wt.\%) of the samples.

\begin{tabular}{llll}
\hline Chemical elements & $\begin{array}{l}\text { MnOx-I } \\
\text { wt.\% }\end{array}$ & $\begin{array}{l}\text { MnOx-M } \\
\text { wt. \% }\end{array}$ & $\begin{array}{l}\text { MnOx-D } \\
\text { wt. \% }\end{array}$ \\
\hline $\mathrm{Mn}$ & 40.70 & 43.73 & 43.30 \\
$\mathrm{O}$ & 47.26 & 41.82 & 49.19 \\
$\mathrm{Al}$ & 1.12 & 0.86 & 0.55 \\
$\mathrm{~K}$ & 0.08 & - & - \\
$\mathrm{Ba}$ & 0.41 & - & - \\
$\mathrm{Si}$ & 1.70 & 1.38 & 0.33 \\
$\mathrm{Fe}$ & 7.07 & 7.54 & 3.09 \\
$\mathrm{Ni}$ & - & 0.81 & - \\
$\mathrm{Cr}$ & - & 1.32 & - \\
$\mathrm{Mg}$ & 0.42 & - & - \\
$\mathrm{Na}$ & - & 0.33 & 0.86 \\
$\mathrm{C}$ & - & - & 2.07 \\
\hline
\end{tabular}




\subsubsection{Morphology and surface property characterization}

Figure 36 shows morphological features and size distribution of the samples. After the mechanical crushing of the sample MnOx-I (more suitable for the milling), which contains pieces with a diameter of about 500 micrometres or even bigger (Figure 36a). After the milling (twostaged wet milling) particle size of the MnOx-M was decreased to $<500 \mathrm{~nm}$ (Figure 36c). Due to the decreases in the manganese oxide particle size, the dissolution rate of manganese dioxide was increased [188][189]. MnOx-D was electrochemically deposited on carbon paper (Figure 36b). As seen in Figure 36b, the carbon paper electrode surface below the red dash line was immersed (deposited) and above the line was not immersed (original carbon paper) surface. Figure 36d reveals that electrochemically formed $\mathrm{MnOx}$ contains tiny sheet-like or flower-like structure sized about $100 \mathrm{~nm}$ same as the flower-like $\mathrm{Mn}_{3} \mathrm{O}_{4}$ [190]. Those tiny particles were connected as knitted cotton by the cathodic formation of manganese particles. Transmission electron microscopic image reveals the true morphological shape of the materials in Figure 36e-f.
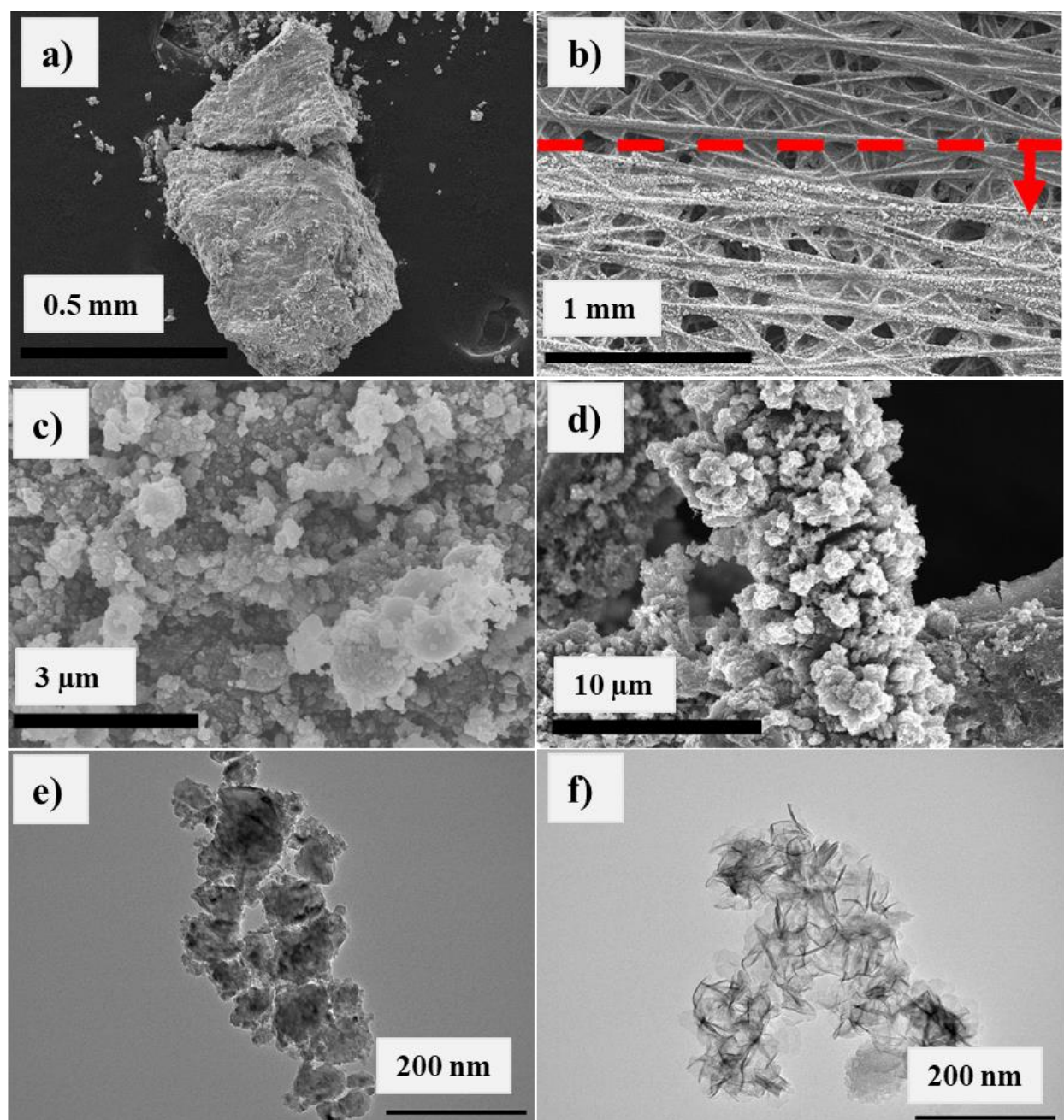

f)

Figure 36. Scanning electron microscopic image of the samples; a) MnOx-I, b) MnOx-D/CP, c) MnOx$\mathrm{M}$ at higher magnification and d) $\mathrm{MnOx}-\mathrm{D} / \mathrm{CP}$ at higher magnification. Transmission electron microscopic image of MnOx-M (e) and MnOx-D/CP (f). 


\subsection{Application test results and discussions}

\subsubsection{Oxygen reduction reaction (ORR) catalyst Birnessite}

\subsubsection{Cyclic voltammogram}

ORR activity of the samples was examined using cyclic voltammetry and linear sweep voltammetry and their stability were tested by the chronoamperometric method. All electrochemical measurement was performed in alkaline media $(0.1 \mathrm{M} \mathrm{KOH})$ in a three-electrode glass cell, using glassy carbon electrode modified with the samples as the working electrode, $\mathrm{Ag} / \mathrm{AgCl}$ electrode as reference electrode and platinum wire as a counter electrode. As Figure 37 shows, a reduction peak appears on the voltammograms measured in the oxygen-saturated electrolyte compared to the background measured in nitrogen saturated electrolyte. The peak position was $0.73 \mathrm{~V}$ vs RHE in the case of pristine Birnessite (Figure 37a) while it was $0.77 \mathrm{~V}$ vs RHE in the case of the $\mathrm{Cu}^{2+} /$ Birnessite (Figure 37) modified GCE. The onset potential of the pristine Birnessite was measured to be $0.8 \mathrm{~V}$ vs RHE while this value was shifted in the case of the $\mathrm{Cu}^{2+} /$ Birnessite modified GCE to $0.87 \mathrm{~V}$ vs RHE, similarly to the shift of the reduction peak position. These values are comparable to the results observed for common ORR catalysts [191]. Notably, the voltammograms in Figure 37b show two oxidation peaks at 0.57 and $0.82 \mathrm{~V}$ vs RHE, which correspond to the oxidation peaks of $\mathrm{Cu}$ to $\mathrm{Cu}(\mathrm{I})$ and $\mathrm{Cu}(\mathrm{I})$ to $\mathrm{Cu}(\mathrm{II})$, respectively [192]. Elemental $\mathrm{Cu}$ can be originated from the reduction process of the $\mathrm{Cu}(\mathrm{II})$ during the electrochemical measurement [193]. The reduction peaks are not visible on the measured voltammograms, likely because of the small amount of copper present in the sample, which gives relatively small current values during the reduction process compared to that of the parallel oxygen reduction reaction [194].
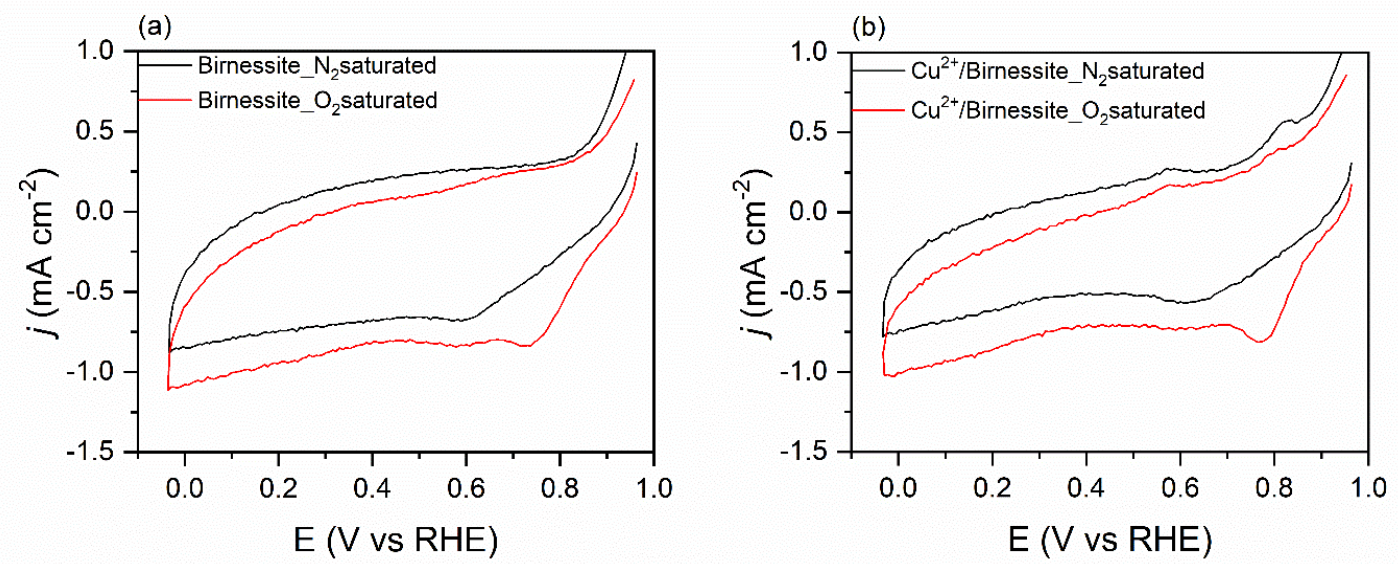

Figure 37. Cyclic voltammograms of the GCE electrodes modified with the as-prepared (a) Birnessite samples, and (b) $\mathrm{Cu}^{2+} /$ Birnessite samples. All measurements were carried out in $0.1 \mathrm{M} \mathrm{KOH}$ solution at $10 \mathrm{mVs}^{-1}$ scan rates. 


\subsubsection{Linear sweep voltammetry and electron transfer number}

Figure 38a-b shows the LSV curves of the glassy carbon electrodes modified with the asprepared samples. As it shows, the current density was increased with increasing rotation rates. Electron transfer numbers were calculated from the linear sweep voltammograms at different rotation rates by using the Koutecky-Levich equation (17) [195]. The Koutecky-Levich plot of the Birnessite-modified GCE electrodes at various potentials is depicted in Figure 38c-d. The parallel straight trend lines can be attributed to the first-order reaction kinetics of the ORR [196]. The extrapolated K-L plots have non-zero intercepts, thus mixed kinetic-diffusion control exists in the investigated potential range [197].

$$
\frac{1}{j}=\frac{1}{j_{k}}+\frac{1}{j_{d}}=\frac{1}{n F k c_{O_{2}}^{b}}+\frac{1}{0.62 n F D_{O_{2}}^{2 / 3} v^{-1 / 6} c_{O_{2}}^{b} \omega^{1 / 2}}
$$

where $j_{k}$ and $j_{d}$ are the kinetic and diffusion-limited current densities, while $j$ is the experimentally measured current density, $n$ is the electron transfer number, (the number of the electrons transferred per oxygen molecule), $F$ is the Faraday constant, $k$ is the rate constant of the oxygen reduction reaction, $c_{O_{2}}^{b}$ is the oxygen concentration in the electrolyte $\left(1.2 \times 10^{-6} \mathrm{~mol} \mathrm{~cm}^{-3}\right.$ in $0.1 \mathrm{M} \mathrm{KOH}$ at $\left.23^{\circ} \mathrm{C}\right)$ [198]. $D_{\mathrm{O}_{2}}$ is the diffusion coefficient of oxygen in the electrolyte (1.9x 10${ }^{5} \mathrm{~cm}^{2} \mathrm{~s}^{-1}$ in $0.1 \mathrm{M} \mathrm{KOH}$ at $\left.23{ }^{\circ} \mathrm{C}\right)$ [198], $v$ is the kinetic viscosity of the solution $\left(8.9 \times 10^{-3} \mathrm{~cm}^{2} \mathrm{~s}^{-1}\right)$ [199] and $\omega$ is the angular velocity of the electrode $\left[\mathrm{rad} \mathrm{s}^{-1}\right]$. One revolution per second corresponds to $2 \pi \mathrm{rad} \mathrm{s}^{-1}$ [200].
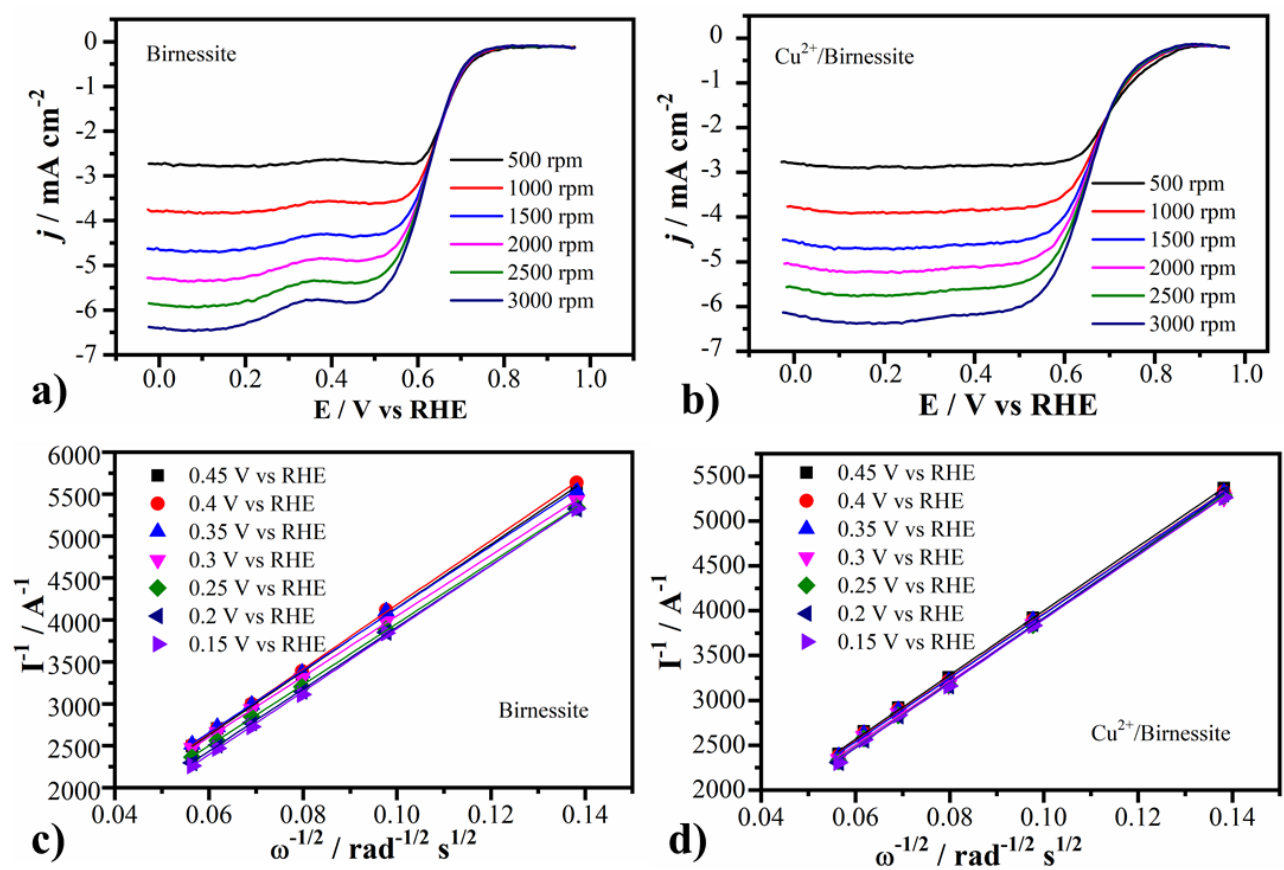

Figure 38. LSV curves of the GCE modified with (a) Birnessite and (b) $\mathrm{Cu}^{2+} / \mathrm{Birnessite}$. KouteckyLevich plots of GCE modified with (c) Birnessite, and (d) $\mathrm{Cu}^{2+} / \mathrm{Birnessite}$ obtained from rotating disk electrode LSV measurements. 
Figure 39a shows the comparison of the LSV curves at 1500 rpm rotation rate. The reduction peak shifted from $0.8 \mathrm{~V}$ to $0.87 \mathrm{~V}$, although the reduction current densities (taken at $0 \mathrm{~V}$ vs RHE) did not change after the intercalation, which was measured to be $4.6 \mathrm{~mA} \mathrm{~cm}^{-2}$ for both pristine Birnessite and $\mathrm{Cu}^{2+} /$ Birnessite. The calculated electron transfer numbers were summarized in Figure 39b. It is seen that the calculated electron transfer numbers are close to 4 ( 3.4 and 3.6) in both Birnessite and $\mathrm{Cu}^{2+} /$ Birnessite case, and the oxygen reduction reaction mainly proceeds through the four-electron pathway with their use, proving that both samples show great promise as a cathode catalyst material for fuel cells. The ORR activity was improved with $\mathrm{Cu}^{2+}$ ion-doped Birnessite catalyst compared to the activity with pristine Birnessite catalyst, based on the calculated $\sim 10 \%$ electron transfer number increment, and the measured positive shift in the oxygen reduction potential peak and onset potential. These phenomena can be explained by several causes based on the literature. As others already stated, the $\mathrm{Mn}^{3+} / \mathrm{Mn}^{4+}$ oxidation state ratio plays an important role in ORR catalytic activity and ion-tuning $\left(\mathrm{Ag}^{+}\right.$and $\left.\mathrm{Zr}^{4+}\right)$ increases the $\mathrm{Mn}^{3+}$ ratio in birnessite type manganese oxides [113,201,202]. As shown in Raman spectra (Figure 20a) the peak observed at $697 \mathrm{~cm}^{-1}$ corresponds to changes of $\mathrm{Mn}^{4+} / \mathrm{Mn}^{3+}$ ratio in the birnessite structure and disordering of the octahedral sheets when $\mathrm{Cu}^{2+}$-ion are integrated into the interlayer space [146]. Wang et al. found that the mutual action between the intercalated ion $\mathrm{Zr}^{4+}$ (in our case $\mathrm{Cu}^{2+}$ ) and the $\mathrm{Mn}^{3+}$ ions results in increased $\mathrm{O}_{2}$ adsorption for ORR [201]. A similar connection can be hypothesized between the birnessite and the intercalated copper ion, as others have already investigated the adsorption of oxygen species to the surface of similar material and found that there is a strong synergistic effect between copper and manganese [193][203]. Likewise, the smaller particle size is boosting the activity owing to the larger surface-to-bulk ratio and numerous surface defects. Higher surface areas provide more active sites of the contact between catalyst and electrolyte [204].
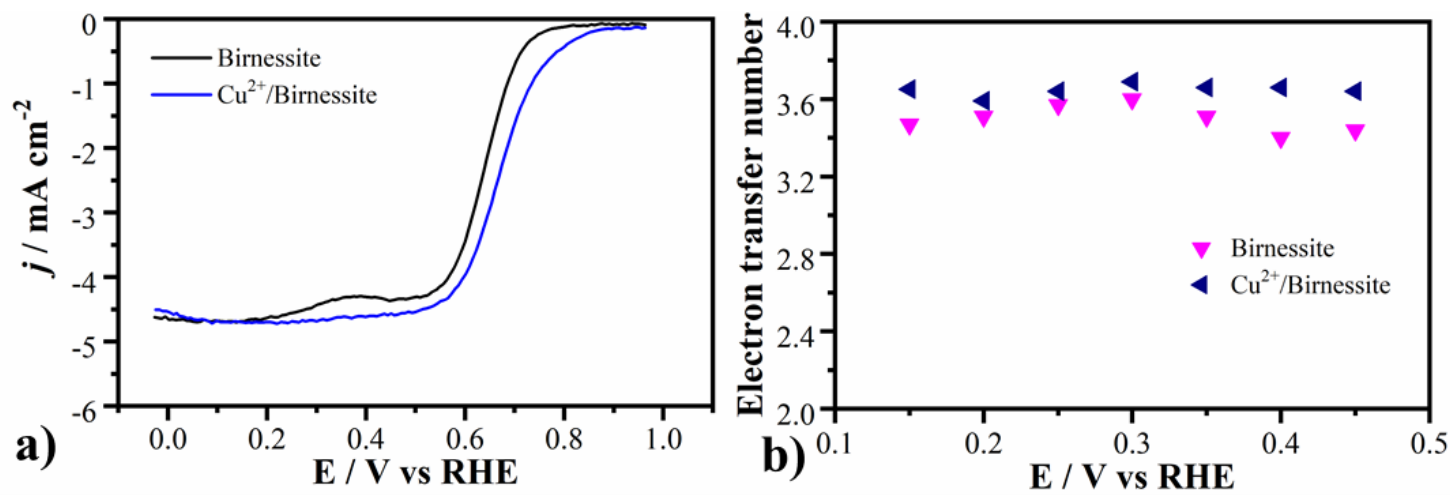

Figure 39. LSV curves of the as-prepared sample measured at $1500 \mathrm{rpm}$ (a) and summary of the calculated electron transfer numbers (b). All measurements were carried out in $0.1 \mathrm{M} \mathrm{KOH}$ solution at 10 $\mathrm{mVs}^{-1}$ scan rates. 


\subsubsection{Tafel slope and stability}

Figure 40a shows the LSV derived Tafel slopes, where a slight increase can be experienced and the value was found to be $-99,8 \mathrm{mV} /$ decade for pristine Birnessite $\mathrm{mV} /$ decade and $-94,4$ for the $\mathrm{Cu}^{2+} /$ Birnessite. These values are also similar to those reported in the literature (ref: [106], [113] from Table 9). The stability of the catalysts was evaluated by measuring the current retention-operating time curves with the chronoamperometric method at $0.4 \mathrm{~V}$ (vs RHE) potential in oxygen-saturated $0.1 \mathrm{M} \mathrm{KOH}$ solution at $1500 \mathrm{rpm}$ rotating rate as seen in Figure 40b. The stability study reveals that the as-synthesized birnessites have high stability with over $10000 \mathrm{~s}$ operating time. It is exciting to note that $\mathrm{Cu}^{2+} /$ Birnessite shows higher stability $(94.8 \%$ current retention) than the pristine Birnessite sample ( $87.4 \%$ current retention), which can be the results of the interlayer copper ion stabilizing the $\mathrm{Mn}^{3+} / \mathrm{Mn}^{4+}$ species in the catalyst during ORR [205]. As Yadav et al. explain, the reversibly intercalated copper stabilizes and enhances its charge transfer characteristics. As can be seen in Figure 37b, a portion of copper ions can be reduced by oxygen and form an oxidized copper state, which is typical phenomena for the copper included ORR catalysts [192]. The comparison of the ORR catalytic activity test results of two synthesized samples with those of the literature can be seen in Table 9. The pristine birnessite and $\mathrm{Cu}^{2+} /$ Birnessite samples both can be utilized as a cathode catalyst in fuel cells as the results are comparable to other already published manganese oxide-based ORR catalysts.
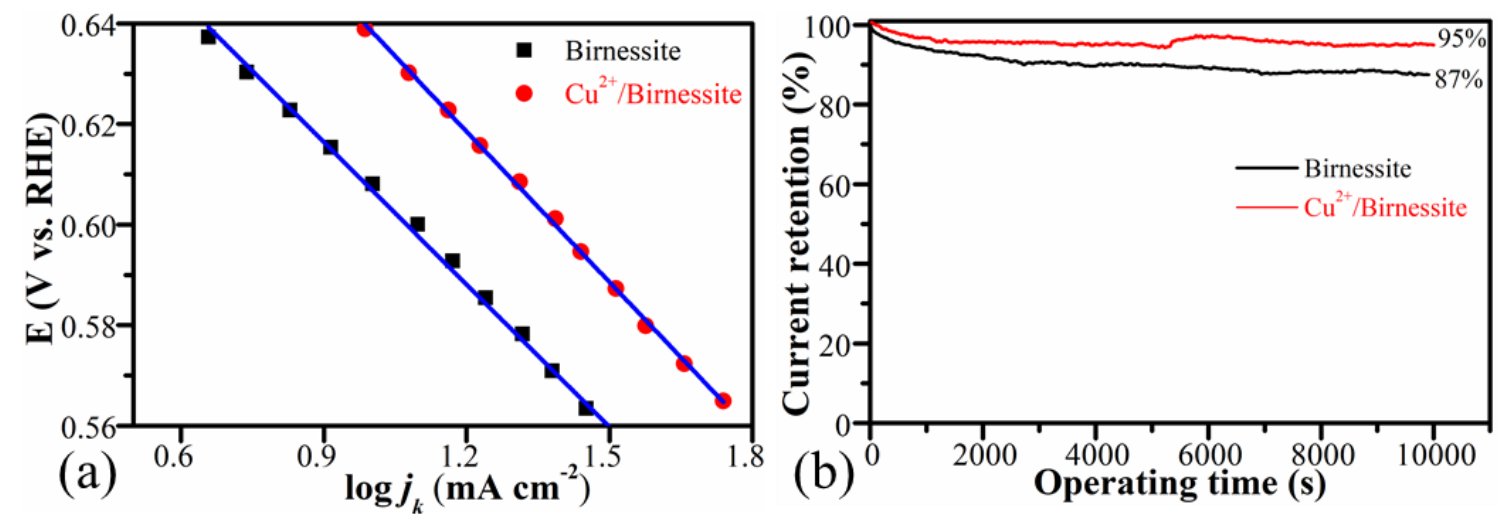

Figure 40. (a) Tafel slopes derived from LSV data and (b) Stability measurement of the samples measured at $0,4 \mathrm{~V}$ (vs RHE) in oxygen saturated electrolyte at $1500 \mathrm{rpm}$ rotating rate. All measurements were carried out in $0.1 \mathrm{M} \mathrm{KOH}$ solution at $10 \mathrm{mVs}^{-1}$ scan rates. 
Table 9. Manganese oxide-based catalysts and $\mathrm{Cu}$ doped different support catalysts for ORR.

\begin{tabular}{|c|c|c|c|c|c|c|c|}
\hline Catalyst & $\begin{array}{c}\text { Eonset } \\
\text { (V) }\end{array}$ & $\begin{array}{l}\mathbf{E}_{1 / 2} \\
(\mathbf{V})\end{array}$ & $\begin{array}{c}\text { Tafel } \\
\text { slope, } \\
\mathrm{mV}\end{array}$ & $\begin{array}{c}\text { ETN } \\
(\mathbf{n})\end{array}$ & $\begin{array}{l}\text { Electrolyte } \\
\text { solution } \\
\text { (M) }\end{array}$ & $\begin{array}{c}\text { Stability test } \\
\text { operation time } \\
\text { (s), retention } \\
(\%)\end{array}$ & Reference \\
\hline Birnessite $^{\mathrm{a}}$ & 0.8 & 0.64 & $-99,8$ & 3.4 & $0.1 \mathrm{KOH}$ & $10,000 \mathrm{sec}, 87 \%$ & $\begin{array}{l}\text { This } \\
\text { study }\end{array}$ \\
\hline $\mathrm{Cu}^{2+} /$ Birnessite $^{\mathrm{a}}$ & 0.87 & 0.67 & $-94,4$ & 3.6 & $0.1 \mathrm{KOH}$ & $10,000 \mathrm{sec}, 95 \%$ & $\begin{array}{l}\text { This } \\
\text { study }\end{array}$ \\
\hline $\mathrm{Ag}-\mathrm{MnO}_{2}{ }^{\mathrm{c}}$ & 0.83 & - & 89 & 4 & $0.1 \mathrm{KOH}$ & $45,000 \mathrm{sec}, 91 \%$ & [106] \\
\hline $\mathrm{Ag}-\mathrm{MnO}_{2} / \mathrm{C}^{\mathrm{c}}$ & 0.87 & 0.80 & -79 & 3.9 & $0.1 \mathrm{KOH}$ & $45,000 \mathrm{sec}, 97 \%$ & [113] \\
\hline $\begin{array}{l}\mathrm{MnO}_{2} \\
\text { (polymorphs) }\end{array}$ & - & - & - & - & $6 \mathrm{KOH}$ & - & [114] \\
\hline $\mathrm{Cu}-\alpha-\mathrm{MnO}_{2}{ }^{\mathrm{b}}$ & -0.09 & -0.30 & - & 3.31 & $0.1 \mathrm{KOH}$ & - & [117] \\
\hline $\mathrm{Mn}_{3} \mathrm{O}_{4} /$ Nano-C ${ }^{\mathrm{d}}$ & 0.87 & 0.85 & - & 3.9 & $0.1 \mathrm{KOH}$ & $20,000 \mathrm{sec}, 97 \%$ & [206] \\
\hline $\mathrm{Mn}_{2} \mathrm{O}_{3}, \mathrm{MnO}_{2}{ }^{\mathrm{c}}$ & 0.4 & - & - & 4 & $0.1 \mathrm{KOH}$ & - & [207] \\
\hline $\mathrm{MnO}_{\mathrm{x}} / \mathrm{C}^{\mathrm{c}}$ & - & $\begin{array}{l}0.04- \\
0.05\end{array}$ & 50 & 2.4 & $0.1 \mathrm{KOH}$ & - & [208] \\
\hline $\mathrm{MnOx}-\mathrm{C}(\mathrm{D})^{\mathrm{c}}$ & - & - & - & 3.81 & $0.1 \mathrm{KOH}$ & - & [209] \\
\hline $\mathrm{Ni}-\mathrm{MnO}_{\mathrm{x}} / \mathrm{C}^{\mathrm{c}}$ & 0.40 & - & 55 & 4 & $1 \mathrm{NaOH}$ & - & [210] \\
\hline $\mathrm{La}_{2 / 3} \mathrm{Sr}_{1 / 3} \mathrm{MnO}_{3}{ }^{\mathrm{b}}$ & $\sim 0.85$ & - & - & $\sim 4$ & - & - & [211] \\
\hline $\mathrm{NiMnO}_{2}-4.9^{\mathrm{b}}$ & 0.89 & 0.70 & 68 & 3.66 & $0.1 \mathrm{KOH}$ & $5000 \mathrm{sec},>90 \%$ & [202] \\
\hline \multicolumn{8}{|c|}{ Copper doped different support materials } \\
\hline $\mathrm{Cu}-\mathrm{N}-\mathrm{rGO}^{\mathrm{b}}$ & 0.91 & 0.78 & - & $\sim 4$ & $0.1 \mathrm{KOH}$ & $10,000 \mathrm{sec}, 92 \%$ & [212] \\
\hline $\begin{array}{l}8 \% \mathrm{NS}-\mathrm{RGO}- \\
\mathrm{Cu}-\mathrm{MOF}\end{array}$ & -0.06 & - & - & 3.35 & $0.1 \mathrm{KOH}$ & - & {$[213]$} \\
\hline $\mathrm{Cu} / \mathrm{Pt}$ & - & 0.87 & -50 & $\sim 4$ & $0.2 \mathrm{NaOH}$ & $2000 \mathrm{sec}, 65 \%$ & [214] \\
\hline $\mathrm{Cu}-\mathrm{N}-\mathrm{C}^{\mathrm{d}}$ & -0.06 & -0.15 & - & 3.92 & $0.1 \mathrm{KOH}$ & $20,000 \mathrm{sec}, 92 \%$ & [215] \\
\hline $\mathrm{M}-\mathrm{NC}-\mathrm{CoCu} \mathrm{u}^{\mathrm{a}}$ & 0.85 & 0.75 & 63 & 3.9 & $0.1 \mathrm{KOH}$ & $\sim 60,000 \mathrm{sec}, 90 \%$ & [216] \\
\hline
\end{tabular}

\subsubsection{Carbon dioxide hydrogenation catalyst ball-milled $\mathrm{MnOx}$}

Manganese-oxides prepared with different milling speed as well as several $\mathrm{Pt}$ and $\mathrm{Cu}$ doped (loaded with ball milling, wet impregnation method and ultrasonication assisted addition of nanoparticles) manganese-oxides tested in $\mathrm{CO}_{2}$ hydrogenation to form carbon-monoxide and methane at $573-823 \mathrm{~K}$ in a fixed-bed continuous-flow catalytic reactor at ambient pressure. The catalytic activity was monitored by the consumption rate and selectivity, which is discussed in the following chapters. The reaction rates and calculated activation energies for $\mathrm{CO}_{2}$ hydrogenation reactions over all samples are summarized in Table $\mathbf{1 0 .}$

\subsubsection{Effect of milling speed}

All the ball-milled manganese-oxide prepared with different milling speed (M200, M450, $\mathrm{M} 600$ ) were active in $\mathrm{CO}_{2}$ hydrogenation reaction at $>600 \mathrm{~K}$ and was producing mostly carbonmonoxide besides a small amount of methane (Figure 41a). In the case of the reaction tested at 
$873 \mathrm{~K}, \mathrm{M} 600$ catalysts showed the highest $\mathrm{CO}_{2}$ consumption rate $\left(\sim 20.000 \mathrm{nmol} \cdot \mathrm{g}^{-1} \cdot \mathrm{s}^{-1}\right)$ followed by M450 (17.500 $\left.\mathrm{nmol} \cdot \mathrm{g}^{-1} \cdot \mathrm{s}^{-1}\right)$. Both M600 and M450 were almost two times more active compared to the catalyst milled at $200 \mathrm{rpm}\left(\sim 10.000 \mathrm{nmol} \cdot \mathrm{g}^{-1} \cdot \mathrm{s}^{-1}\right)$. The high activity of manganese-oxide milled at higher speeds can be attributed to the high specific surface area [217] and porosity as well as the morphological differences. It is interesting to note that these kinds of noble metal-free oxides have unusual activity compared to mesoporous $\mathrm{MnO}_{2}$ samples. Also, they are competitive with other metal-based (e.g. Ni, Co) oxides in $\mathrm{CO}_{2}$ activation [134]. All M200, M450 and M600 were stable at $873 \mathrm{~K}$ under reaction condition for 10 hours (Figure 41b).

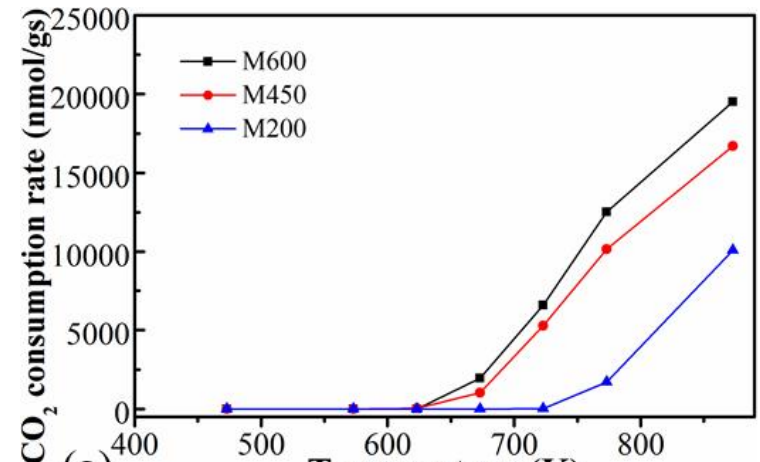

(a)

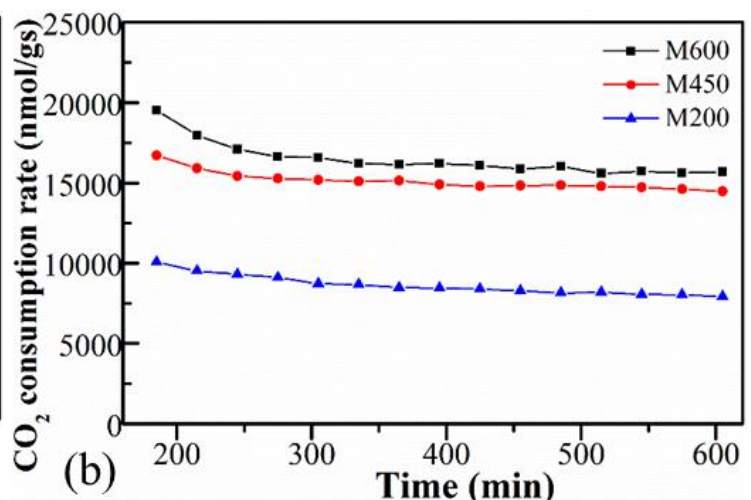

(b)

Time (min)

Figure 41. The $\mathrm{CO}_{2}$ consumption rate of manganese oxides synthesized by different milling speed (200 rpm-M200, 450 rpm-M450 and 600 rpm-M600) as a function of temperature (a) and function of time (b).

Furthermore, X-ray diffraction patterns of the pure samples milled with different speed after the pretreatment in hydrogen and after the $\mathrm{CO}_{2}$ hydrogenation test were displayed in Figure 42. A diversity in the ratio of $\mathrm{Mn}^{4+}: \mathrm{Mn}^{3+}: \mathrm{Mn}^{2+}$ is clearly shown by the detected phases, which can be another explanation of the catalytic activity difference. After the pretreatment, the birnessite type $\sigma-\mathrm{MnO}_{2}$ ratio decreased, and mostly amorphous or nano-scaled $\mathrm{Mn}(\mathrm{II}, \mathrm{III})_{3} \mathrm{O}_{4}$ and $\mathrm{Mn}(\mathrm{II}) \mathrm{O}$ presented in the catalyst before the reaction. But after the $\mathrm{CO}_{2}$ hydrogenation, all three samples have the same $\mathrm{MnO}$ crystal phase on the surface.

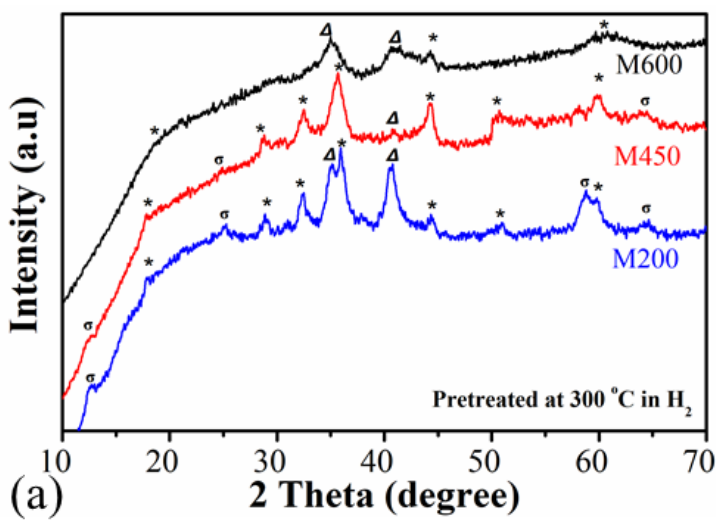

(a)

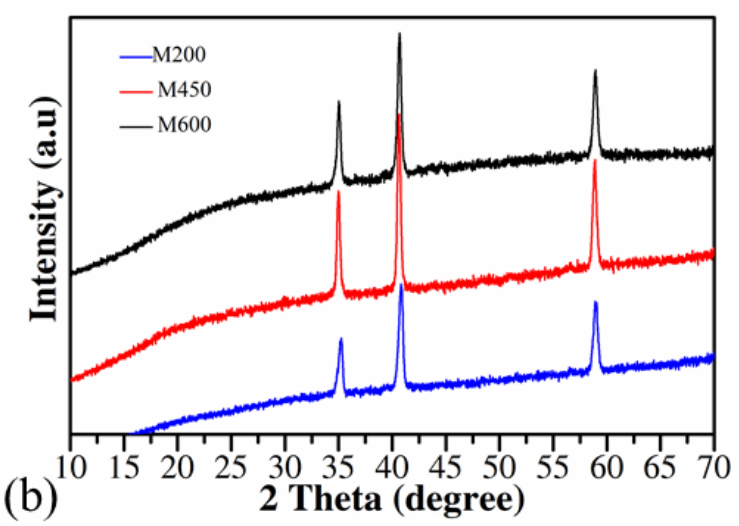

(b)

Figure 42. X-ray diffraction patterns of the samples $\left\{\left\{\right.\right.$ * birnessite type $\sigma-\mathrm{MnO}_{2}, \boldsymbol{\|} \mathrm{Mn}_{3} \mathrm{O}_{4}$ phase, $\Delta$ - $\mathrm{MnO}$ phase $\}$ pretreated (a) and after $\mathrm{CO}_{2}$ hydrogenation test (b). 


\subsubsection{Effect of one-pot loading of Pt and Cu doped catalysts}

To enhance the catalytic activity, we used a simple one-pot method to dope $3 \mathrm{wt} . \%$ of Pt and $\mathrm{Cu}$ into the manganese-oxide nanostructures during the milling process. The catalytic activity was significantly enhanced by adding Pt into the manganese-oxide structure at $673 \mathrm{~K}$ (Figure 43a.). In the case of the Pt-doped manganese-oxide catalyst milled under different speed, 12-13 times increment in catalytic activity observed, showing the presence of the significant role of the Pt where the effect of the milling speed was insignificant. Cu-doping resulted in a $\sim 2.5$ times increment in catalytic activity compared to the pure manganese-oxide catalysts. At higher temperature $(873 \mathrm{~K}$ ) displayed in Figure 43b, the catalytic boosting effect of Pt, as well as $\mathrm{Cu}$ doping, was negligible. All the metal-loaded catalysts showed similarly high activity ( 20.000 $\mathrm{nmol} \cdot \mathrm{g}^{-1} \cdot \mathrm{s}^{-1}$ ) as the pure manganese-oxide milled at $600 \mathrm{rpm}$. This phenomenon shows that the particular mixed $\mathrm{Mn}(\mathrm{IV}$, III, II)-oxide role is crucial in the catalytic activity at higher temperatures. These changes illustrate that temperature plays a vital role in the manganese oxidebased catalysts due to crystal structure changes and the reducibility of the manganese oxides.

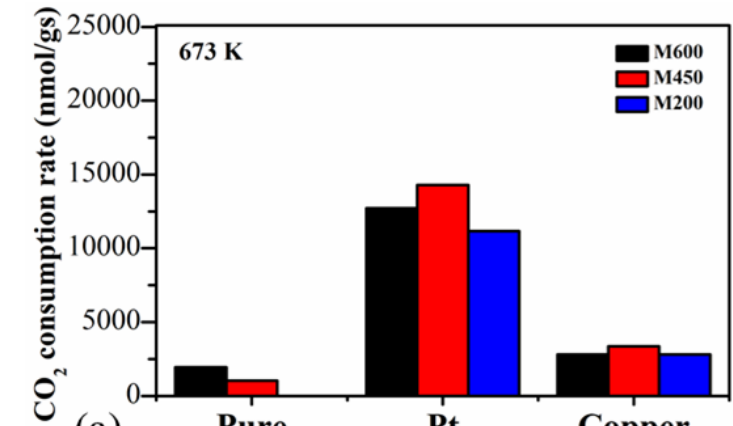

(a)

Pure

$\mathbf{P t}$

Copper

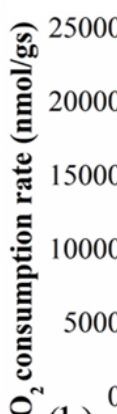

(b)

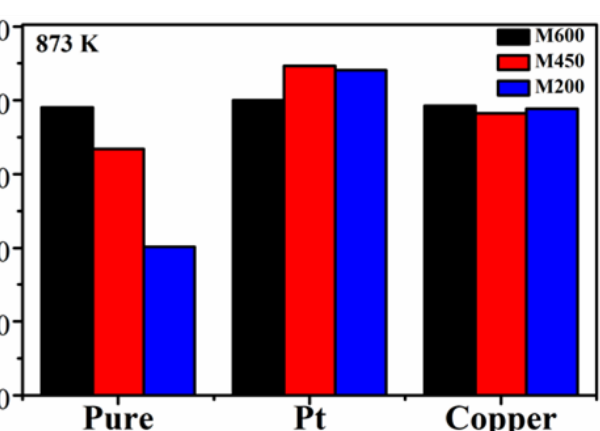

Pure

Copper

Figure 43. Temperature effect for the $\mathrm{CO}_{2}$ consumption rate of the samples at (a) $673 \mathrm{~K}$ and (b) $873 \mathrm{~K}$.

\subsubsection{Effect of Platinum incorporation}

Three different types of Pt-loaded M600 prepared by using one-pot synthesis, incipient wetness impregnation as well as loading of pre-synthesized $5 \mathrm{~nm}$ Pt nanoparticles to the catalysts by ultrasonication. All Pt-doped catalysts displayed almost the same catalytic activity (Figure 44a-b). Usually, the wet impregnation method or even designed surfaces by adding controlled sized nanoparticles resulted in specific loading of the metal onto the surface as well as a catalytic activity increment [218]. These tests support the idea that the main working surface of these kinds of catalysts based on the manganese-oxide, regardless of the quality and type of doped metal onto the surface. 

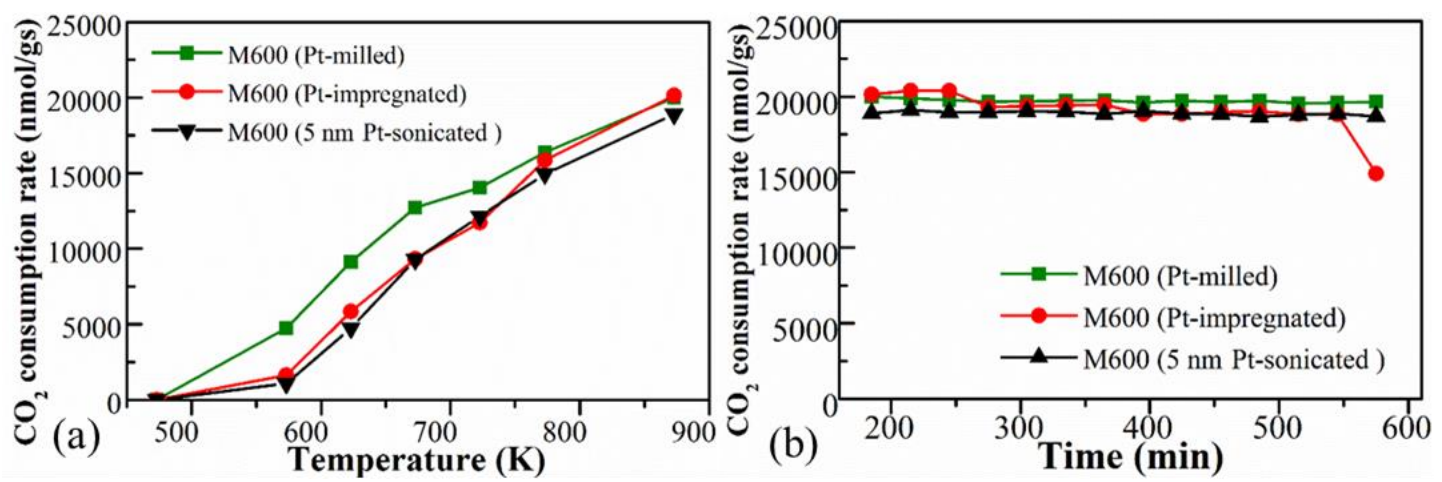

Figure 44. The $\mathrm{CO}_{2}$ consumption rate of the Pt-doped M600 manganese-oxide prepared by the one-pot method, incipient wetness impregnation method as well as designed incorporation of controlled-sized 5 $\mathrm{nm}$ Pt nanoparticles as a function of temperature (a) and function of time (b).

Table 10. Reaction rates (at $673 \mathrm{~K}$ and $873 \mathrm{~K}$ ) and the activation energies for $\mathrm{CO}_{2}$ hydrogenation reactions over the samples at $873 \mathrm{~K}$

\begin{tabular}{llcc}
\hline & \multicolumn{2}{c}{ Over the samples at 873K } & \\
Sample name & $673 \mathrm{~K}$ & $873 \mathrm{~K}$ & $\begin{array}{c}\text { Activation Energy, } \\
\text { kcal/nmol } \\
873 \mathrm{~K}\end{array}$ \\
\hline M200 & - & 10083 & 8.8 \\
M450 & 1038 & 16707 & 9.4 \\
M600 & 1954 & 19523 & 54.9 \\
M200(Cu-milled) & 2811 & 19430 & 8.3 \\
M450(Cu-milled) & 3367 & 19129 & 7.9 \\
M600(Cu-milled) & 6943 & 20722 & 4.4 \\
M200(Pt-milled) & 11186 & 22052 & 3.1 \\
M450(Pt-milled) & 14293 & 22338 & 2.8 \\
M600(Pt-milled) & 12730 & 19996 & 2.9 \\
M600(Pt-impregnated) & 9318 & 20151 & 4.4 \\
M600(5 nm Pt-sonicated) & 9283 & 18895 & 3.6 \\
\hline
\end{tabular}

\subsubsection{Selectivity towards methane}

In the case of selectivity, these catalysts mostly produced carbon-monoxide (> $95 \%)$ and a smaller amount of methane. Most catalysts started to produce methane with a small ratio at elevated temperature $(\sim 623 \mathrm{~K})$ and after a short increment shifting of the products into the formation of carbon monoxide was observed (Figure 45a) as expected from the thermodynamics of the $\mathrm{CO}_{2}$ hydrogenation reaction in the gas phase [134]. In the case of the M600(Pt-milled) catalyst produced by the one-pot milling process, methane formation was significant compared to pure and $\mathrm{Cu}$-loaded catalysts prepared by using different milling speed. The result shows that; 
however, the catalytic activity is not profoundly influencing by the metal-loading, the $\mathrm{Pt} / \mathrm{MnO}_{\mathrm{x}}$ interphase is crucial in the methane selectivity. The Pt-loaded manganese-oxide prepared by the one-pot synthesis has 1.5-2 times higher selectivity towards methane compared to the Pt-loaded $\mathrm{MnO}_{\mathrm{x}}$ catalyst synthesized by the wet impregnation and size-controlled Pt sonication, which shows the influence of the formed $\mathrm{Pt} / \mathrm{MnO}_{\mathrm{x}}$ during the reaction (Figure 45b).
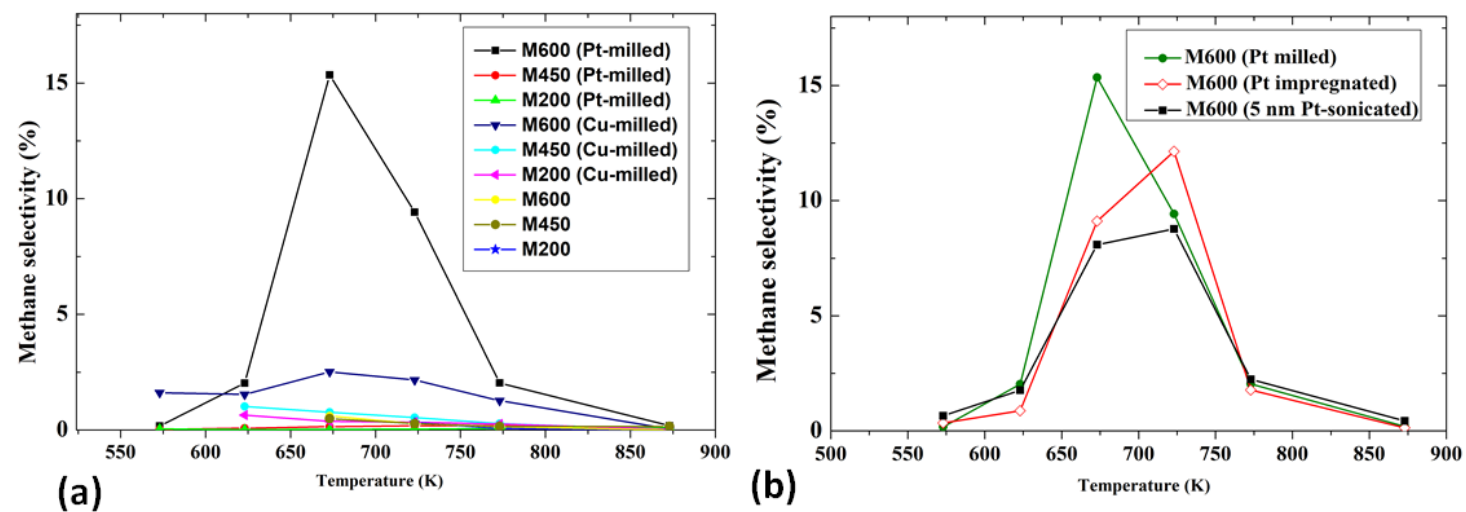

Figure 45. The selectivity of methane during $\mathrm{CO}_{2}$ hydrogenation reaction in the case of (a) pure, Ptloaded, and Cu-loaded catalysts prepared by using different milling speed and (b) M600 loaded with Pt by different methods.

Table 11 displays the formation rate and selectivity towards $\mathrm{CO}$ and $\mathrm{CH}_{4}$ of $\mathrm{Pt}$ incorporated 3 samples: M600(Pt-milled), M600(Pt-impregnated) and M600(5nm Pt-sonicated) at $673 \mathrm{~K}$. In the presence of $\mathrm{Pt}$ in the M600 catalyst prepared by the one-pot ball-milling process, the catalytic activity was $\sim 17$ times higher at $673 \mathrm{~K}$ while it was similar at $823 \mathrm{~K}$ compared to the Pt-free M600 catalyst. While the main product was $\mathrm{CO}$, the highest amount of $\mathrm{CH}_{4}(\sim 20 \%)$ was formed in the case of the Pt-doped M600.

Table 11. The catalytic results of the Pt loaded M600 at 673K (one-pot milled, wet impregnated, and

\begin{tabular}{lcccc}
\hline Catalyst & $\begin{array}{c}\text { CO formation } \\
\text { rate, nmol/sc }\end{array}$ & $\begin{array}{c}\text { CO formation } \\
\text { selectivity, } \%\end{array}$ & $\begin{array}{c}\text { Methane } \\
\text { formation rate, } \\
\text { nmol/sc }\end{array}$ & $\begin{array}{c}\text { Methane } \\
\text { formation } \\
\text { selectivity, } \%\end{array}$ \\
\hline M600(Pt-milled) & 12759 & 82 & 2362 & 15 \\
M600(Pt-impregnated) & 9716 & 89 & 992 & 9 \\
M600(5 nm Pt-sonicated) & 9229 & 90 & 822 & 8 \\
\hline
\end{tabular}

\subsubsection{Determining the oxidation states (XPS)}

For a better understanding of the activity differences of the catalysts, the oxidation states of the Mn species were investigated by ex-situ XPS for samples prepared with low (M200) and high (M600) milling speeds as well as co-milled with Pt salts at 600 rpm (M600-Pt-milled) after 
pretreatment of the samples in $\mathrm{O}_{2}$ followed by $\mathrm{H}_{2}$ at $300^{\circ} \mathrm{C}$ as well as after the $\mathrm{CO}_{2}$ hydrogenation reactions. The Mn $2 p$ regions were fitted with multiplet states taken into consideration (Figure 46) [138].

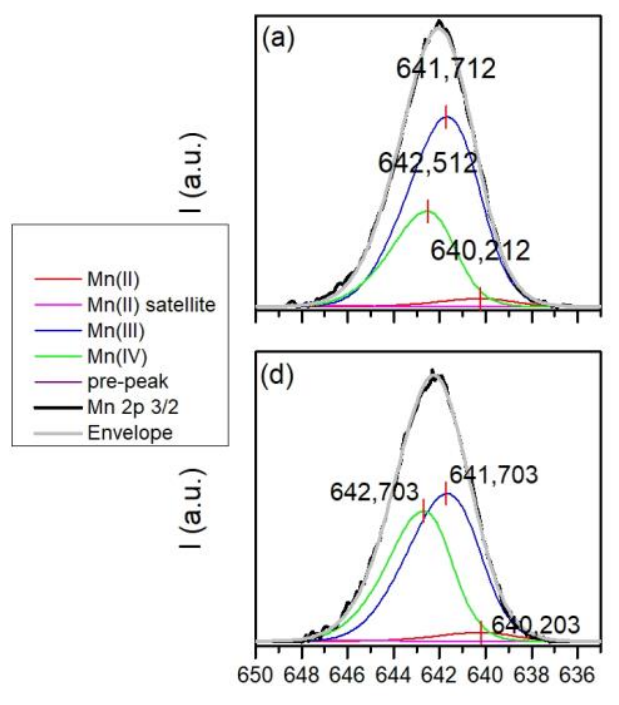

$\mathrm{BE}(\mathrm{eV})$
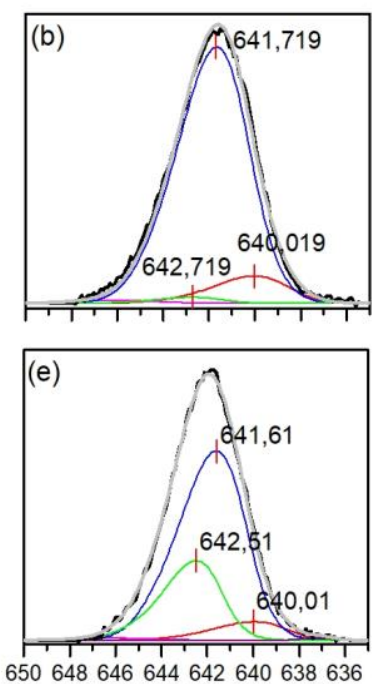

$\mathrm{BE}(\mathrm{eV})$
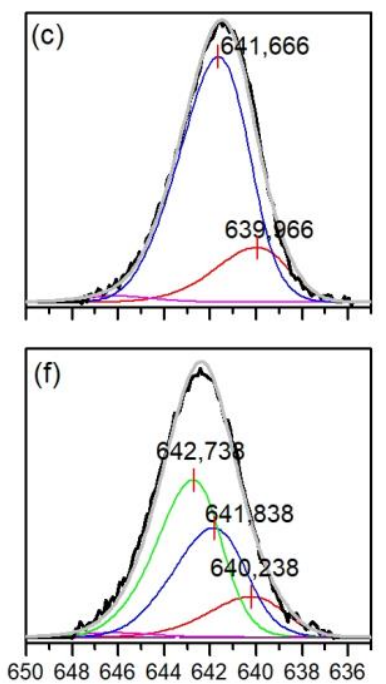

$\mathrm{BE}(\mathrm{eV})$

Figure 46. The collected Mn 2p 3/2 spectra of the different MnOx samples, (a) M200 after pretreatment, (b) M600 after pretreatment, (c) Pt-milled M600 after pretreatment and (d) M200 after the reaction (e) M600 after the reaction, (f) Pt-milled M600 after the reaction.

Before the $\mathrm{CO}_{2}$ hydrogenation (after the pretreatment), in the case of the M200 catalyst, $\mathrm{Mn}(\mathrm{III})$ and $\mathrm{M}(\mathrm{IV})$ presented with a ratio of $\mathrm{Mn}(\mathrm{III}): \mathrm{Mn}(\mathrm{IV})=\sim 2$. However, after the reaction, this ratio decreased to $\sim 1$ showing the presence of the oxidation of the catalyst during the $\mathrm{CO}_{2}$ hydrogenation. Usually, under the hydrogenation processes, the reduction of the surface is favourable [134,219], but the possibility of $\mathrm{CO}_{2}$ dissociation to $\mathrm{CO}$ and $* \mathrm{O}$ followed by the oxidation of the metallic or metal-oxide surface as well as the oxidation of the surface by $\mathrm{H}_{2} \mathrm{O}$ resulted from the Reverse Water Gas Shift Reaction (RWGSR $-\mathrm{CO}_{2}+\mathrm{H}_{2}=>\mathrm{CO}+\mathrm{H}_{2} \mathrm{O}$ ) can be also possible [220,221]. In the case of the M600 catalyst, a small amount of Mn (II) ( 10\%) was observed next to a higher amount of Mn (III) with the absence of Mn (IV) on the surface before the reaction. After the $\mathrm{CO}_{2}$ hydrogenation reaction, the oxidation of the surface was observed as in the case of the M200 sample. The small amount of the Mn (II) was reduced to 3\% and Mn (IV) appeared with a ratio of $\mathrm{Mn}(\mathrm{III}): \mathrm{Mn}(\mathrm{IV})=\sim 3$. The ratios of the Mn oxidation states were calculated based on the peak areas of the fittings in Figure 47. 


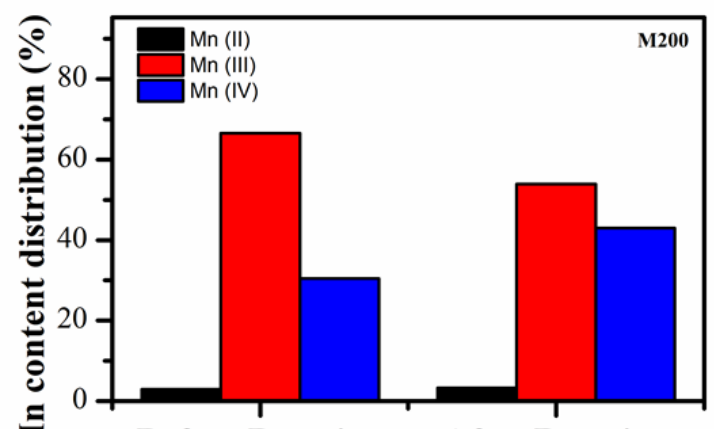

(a)

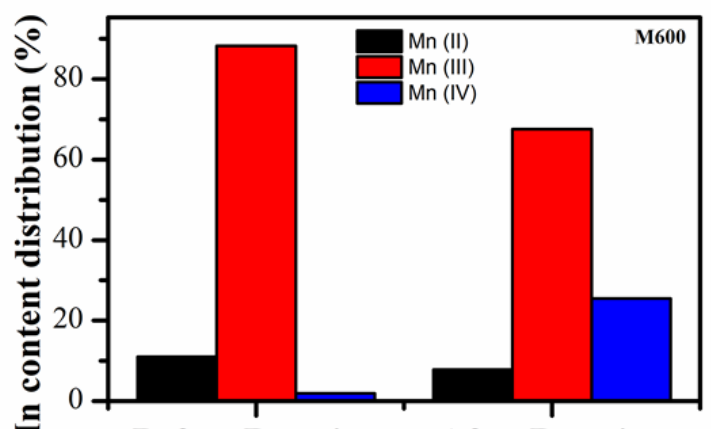

(b) Before Reaction After Reaction

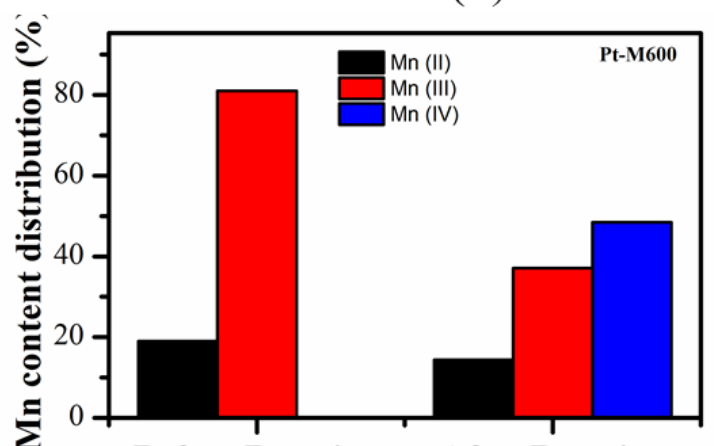

(c) Before Reaction After Reaction

Figure 47. Atomic ratios of $\mathrm{Mn}$ with different oxidation states before $\mathrm{CO}_{2}$ hydrogenation (after pretreatment) and after $\mathrm{CO}_{2}$ hydrogenation reactions for (a) M200, (b) M600, and (c) Pt-milled M600.

As we could see during the catalytic tests (chapter 5.2.2.2), M600 catalysts showed the highest $\mathrm{CO}_{2}$ consumption rate and were almost two times more active compared to M200 at both low and high temperatures. We believe that besides the high specific surface area and porosity as well as the morphological differences the Mn oxidation states play an important role during the reaction. In the case of the M600, the presence of the $\mathrm{Mn}$ (II) and the higher concentration of $\mathrm{Mn}(\mathrm{III})$ could be the reason for the higher catalytic activity. In manganese-based catalyst driven photosynthesis, the presence of $\mathrm{Mn}(\mathrm{II}) \mathrm{Mn}(\mathrm{III})_{3}$ is needed for the production of the photo assembly intermediates and $\mathrm{Mn}(\mathrm{III}) \mathrm{Mn}(\mathrm{IV})_{3}$ was responsible for the oxygen releasing step [222]. We also found that in our recent studies that $\mathrm{Mn}$ (II) helped the reduction of $\mathrm{CO}_{2}$ hydrogenation as support for metallic Cobalt where the reaction followed the format pathway towards $\mathrm{CH}_{4}$ production[223]. We believe that the presence of $\mathrm{Mn}(\mathrm{II})$, as well as the ratio of $\mathrm{Mn}(\mathrm{III}) / \mathrm{Mn}(\mathrm{IV})$, is crucial for this reaction driven by manganese-oxide based catalysts.

Ex-situ XPS data showed that before the reaction Mn (II) was observed with the content of $\sim 20 \%$ next to Mn (III). The higher amount of the reduced phase compared to the pure M600 shows the reducing effect of $\mathrm{Pt}$ under the $\mathrm{H}_{2}$ pretreatment process. However, after the $\mathrm{CO}_{2}$ activation, a huge amount of $\mathrm{Mn}$ (IV) was formed on the surface with an $\mathrm{Mn}(\mathrm{III}) / \mathrm{Mn}$ (IV) ratio of $\sim 1$ beside the slight reduction of the content of $\mathrm{Mn}(\mathrm{II})$ to $\sim 18 \%$. Besides the fact, that the presence of $\mathrm{Pt}$ usually increases the activity of $\mathrm{CO}_{2}$ reduction [224,225], the perturbation of the $\mathrm{Mn}$ 
oxidation state by the Pt can also affect catalytic activity. At lower temperature, the Pt-loading resulted in $\sim 17$ times higher catalytic activity, where the $\mathrm{CH}_{4}$ selectivity was drastically increased. It was interesting, as we know that usually, the presence of Pt helps to produce mostly $\mathrm{CO}$ in the $\mathrm{CO}_{2}$ hydrogenation reaction [219]. On the other hand, at $823 \mathrm{~K}$ the lack of the effect of Pt was observed in catalytic activity compared to pure M600 catalysts. These phenomena can be attributed to the presence of $\mathrm{Mn}(\mathrm{II})$ as well as the different ratios of the oxidation states of the manganese in the oxides. In the future, we will focus on the atomic level understanding of such an easy-to-produce cheap catalyst to reach the highest activity by tuning the oxidation states of the manganese without using precious metals.

In further, we summarized comparison of the $\mathrm{CO}_{2}$ conversion percentage of our Pt loaded samples with previously published studies in Table 12. As seen in the table, our results are proving that efficient manganese oxide catalyst synthesis can be done by a cost-effective one-pot ball milling method even ball milling can be used as a simple method for loading metals.

Table 12. Comparison of $\mathrm{CO}_{2}$ conversion percentage (Pt loaded samples) with previously published references at different temperatures.

\begin{tabular}{lllll}
\hline Catalyst & Synthetic method & $\begin{array}{l}\text { Temperature, } \\
\mathrm{K}\end{array}$ & $\begin{array}{l}\mathrm{CO}_{2} \text { conversion, } \\
(\%)\end{array}$ & Reference \\
\hline $\mathrm{M} 600(\mathrm{Pt}-$ milled) & ball milling & 673 & 42 & This study \\
$\mathrm{M} 600$ (Pt-impregnated) & ball milling/impregnation & 673 & 28 & This study \\
$\mathrm{M} 600(5 \mathrm{~nm}$ Pt-sonicated) & ball milling/sonication & 673 & 28 & This study \\
$\mathrm{Pt} / \mathrm{MnO} 2$ & hard template & 648 & 25 & {$[134]$} \\
$\mathrm{MnOx}-\mathrm{Co} 3 \mathrm{O} 4$ & sol-gel inverse micelle & 523 & 45 & {$[217]$} \\
$\mathrm{PtCo} / \mathrm{CeO} 2$ & - & 573 & 6 & {$[226]$} \\
$\mathrm{K}-\mathrm{Mn}-\mathrm{Fe} / \mathrm{Al} 2 \mathrm{O} 3$ & co-incipient wetness & 836 & 41 & {$[227]$} \\
& impregnation (IWI) & & & {$[228]$} \\
$\mathrm{La}-\mathrm{Mn}-\mathrm{Zn}-\mathrm{Cu}-\mathrm{O}$ & sol-gel & 543 & 13 & {$[229]$} \\
$\mathrm{Mn}-\mathrm{Na} / \mathrm{Fe}$ & co-precipitation & 593 & 37 & {$[230]$} \\
$\mathrm{Pt} / \mathrm{TiO}$ & & 673 & 40 & {$[231]$} \\
$\mathrm{Fe} / \mathrm{SiO} 2-250$ & wet impregnation & 643 & 38 & {$[232]$} \\
$\mathrm{CuO}-\mathrm{ZnO}-\mathrm{Al}{ }_{2} \mathrm{O}_{3}$ & ball milling & 523 & 12 & {$[233]$} \\
$\mathrm{Ni} / \mathrm{SiO} 2$ & sol-gel & 673 & 35 & \\
\hline
\end{tabular}

\subsubsection{Manganese mineral oxide supercapacitor electrode}

The electrochemical performance of the as-prepared sample was investigated by cyclic voltammetry, galvanostatic charge-discharge measurement, and electrochemical impedance spectroscopy. All test was performed in a three-electrode cell system with $\mathrm{KOH}(0.1 \mathrm{M})$ electrolyte, a platinum wire as counter electrode and silver/silver chloride electrode used as a reference electrode. In cyclic voltammetry, applied voltage ranged between $0-1 \mathrm{~V}$ vs $\mathrm{E}_{\mathrm{RHE}}$ with 
a sweep rate of $0.001-0.08 \mathrm{~V} / \mathrm{sec}$. $\mathrm{E}_{\mathrm{RHE}}$ can be calculated with equation (14) comparing it to the $\mathrm{Ag} / \mathrm{AgCI}$ reference electrode.

$$
E_{v S R H E}=E+E_{A g / A g C l}(v S S H E)+0.059 \mathrm{~V} \cdot p H
$$

\subsubsection{Cyclic voltammetry curve}

In Figure 48a CV curves of the bare carbon paper electrode and MnOx-D/CP compared at the same scan rate of $0.03 \mathrm{~V} / \mathrm{sec}$. The $\mathrm{MnOx}-\mathrm{D} / \mathrm{CP}$ shows higher capacitance than bare electrode $(\mathrm{CP})$, which can be explained by the capacitance increase due to deposited manganese oxide. Figure 48b shows the $\mathrm{CV}$ curves of the $\mathrm{MnOx}-\mathrm{D} / \mathrm{CP}$ at different scan rates. As the scan rates increases, capacitance is decreasing with it, which proves the MnOx-D/CP electrode has pseudocapacitance property, it stores energy through electrochemical reaction[234]. At lower scan rates, the electrolyte cation approached deep pores of the electrode, which resulted in higher specific capacitance.
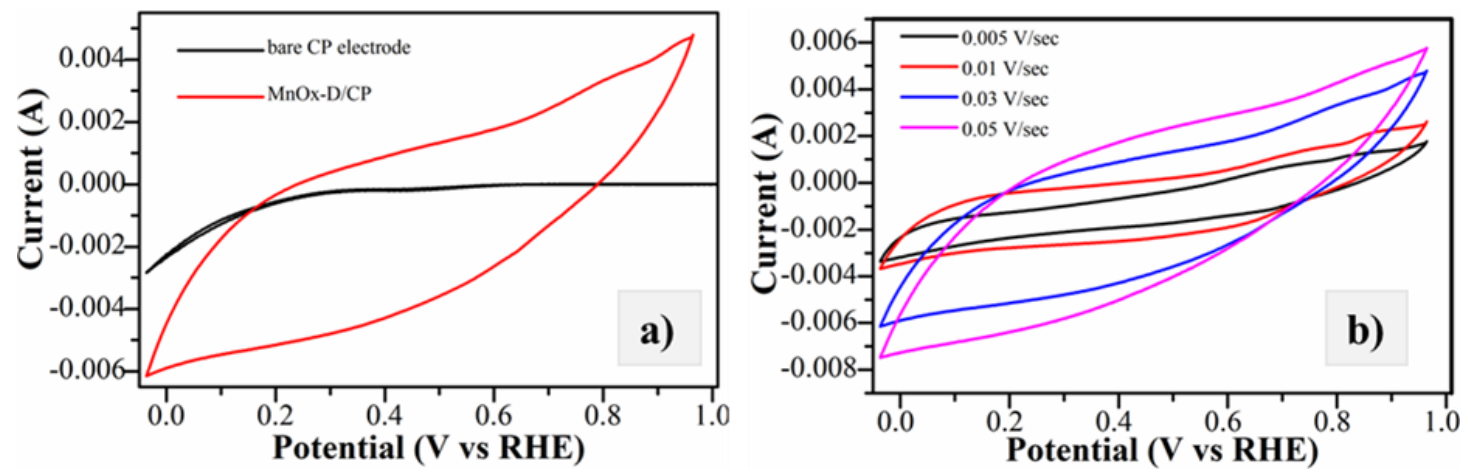

Figure 48. a) the cyclic voltammetry curve of the bare carbon paper electrode and $\mathrm{MnOx}-\mathrm{D} / \mathrm{CP}$ electrode at $0.03 \mathrm{~V} / \mathrm{sec}$ scan rate and b) different scan rates $(0.005,0.01,0.03$ and $0.05 \mathrm{~V} / \mathrm{sec})$ for $\mathrm{MnOx}-\mathrm{D} / \mathrm{CP}$.

The specific capacitance at different scan rates Table 13 was calculated by equation (18) using cyclic voltammetric data of the sample. The specific capacitance of the MnOx-D/CP was 119.6-47.9 F/g depended on applied scan rates $0.005-0.05 \mathrm{~V} / \mathrm{sec}$. The specific capacitance value was comparable to the pure $\mathrm{MnOx}$ electrodes without polymer binders or conductive additives [164][235][236], even higher than some reported values [237][238].

Table 13. The specific capacitance of the $\mathrm{MnOx}-\mathrm{D} / \mathrm{CP}$ from the cyclic voltammetry analysis.

\begin{tabular}{cc}
\hline Scan rate, $\mathbf{V} / \mathbf{s e c}$ & Specific capacitance, $\mathbf{F} / \mathbf{g}$ \\
\hline 0.005 & 119.6 \\
0.01 & 102.3 \\
0.03 & 63.4 \\
0.05 & 47.9 \\
\hline
\end{tabular}


The stability of the electrode was tested by repeating the CV tests more than 2000 times. Figure 49a displays the $C V$ curve of the electrode at the $1^{\text {st }}, 500^{\text {th }}, 1500^{\text {th }}, 2000^{\text {th }}$ and $2100^{\text {th }}$ cycles. The specific capacitance retention was represented in Figure 49b. About 20-30\% of capacitance was decreased in the first hundred cycles, which is a typical problem for pure manganese oxides without additional polymer binder and conductive additives [239][240]. But after the $500^{\text {th }}$ cycle, the capacitance was started to stabilize and $\mathrm{MnOx}-\mathrm{D} / \mathrm{CP}$ capacitance retention decreased by less than $10 \%$ until the $2100^{\text {th }}$ cycle, which is comparable with other works [166] [241][242].

$$
C p=\frac{A}{2 \operatorname{mk}\left(V_{2}-V_{1}\right)}
$$

Here $\mathrm{Cp}$ is the specific capacitance in $\mathrm{F} / \mathrm{g}, \mathrm{A}$ is the area inside in $\mathrm{CV}$ curve with units of $\mathrm{AV}, \mathrm{k}$ is scan rate of $\mathrm{CV}$ in $\mathrm{V} / \mathrm{sec}, \mathrm{m}$ is mass of the active materials, $\mathrm{V}_{2}-\mathrm{V}_{1}$ is the potential window of $\mathrm{CV}$.
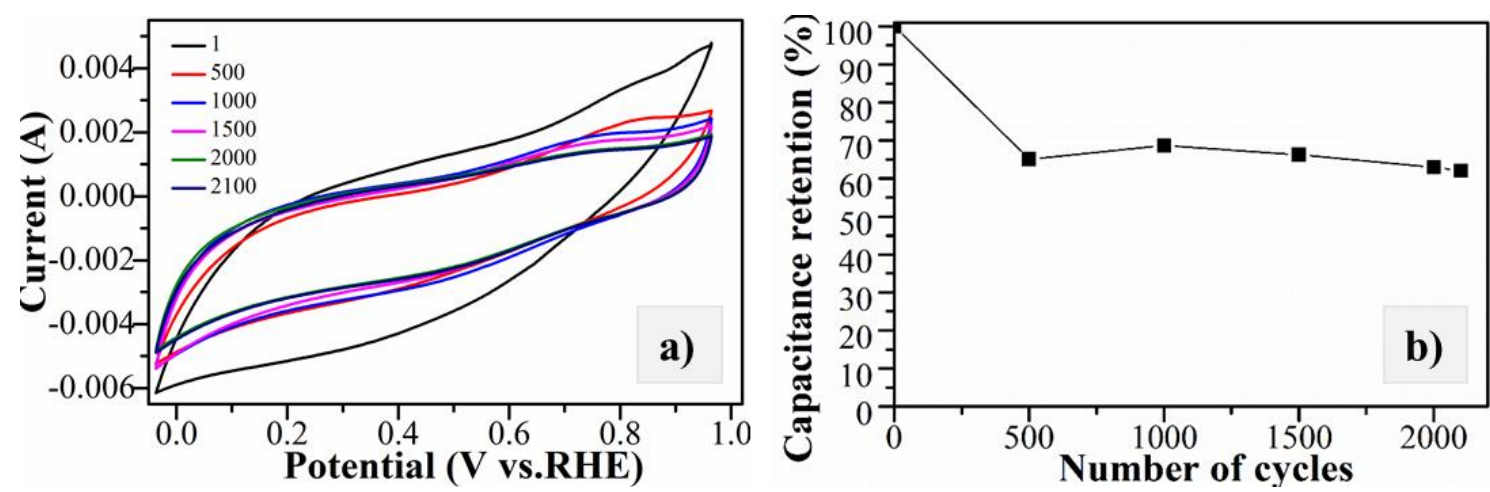

Figure 49. CV curve in a different number of a cycle (a) and specific capacitance retention from the cyclic voltammetry curve by different cycling number(b).

\subsubsection{Galvanostatic charge-discharge curve}

The charge-discharging property was tested with constant current flow and $10 \mathrm{~mA}$ current limit in a three-electrode cell system. The maximum potential limit(cut-off) was set to $0.5 \mathrm{~V}$ for all tests. Galvanostatic charge-discharge curve of $\mathrm{MnOx}-\mathrm{D} / \mathrm{CP}$ at current density$0.6 \mathrm{~A} / \mathrm{g}$ is showed in Figure 50a. I-V response of the MnOx-D/CP curve is almost symmetric for charge and discharge cycles. I-R drop was about $0.05 \mathrm{~V}$, which illustrates the low internal resistance of the material [243]. Figure 50b displays galvanostatic charge-discharge curves at different current densities. At increased current density, the charge-discharge time is shortened and the I-R drop was increased which is caused by the intrinsic resistance of the electrode materials and insufficient Faradic reactions (decreases of electroactive surface area) [241]. But at lower current density broader curve was observed, which reveals that the as-prepared electrode has a good capacitance [244]. 

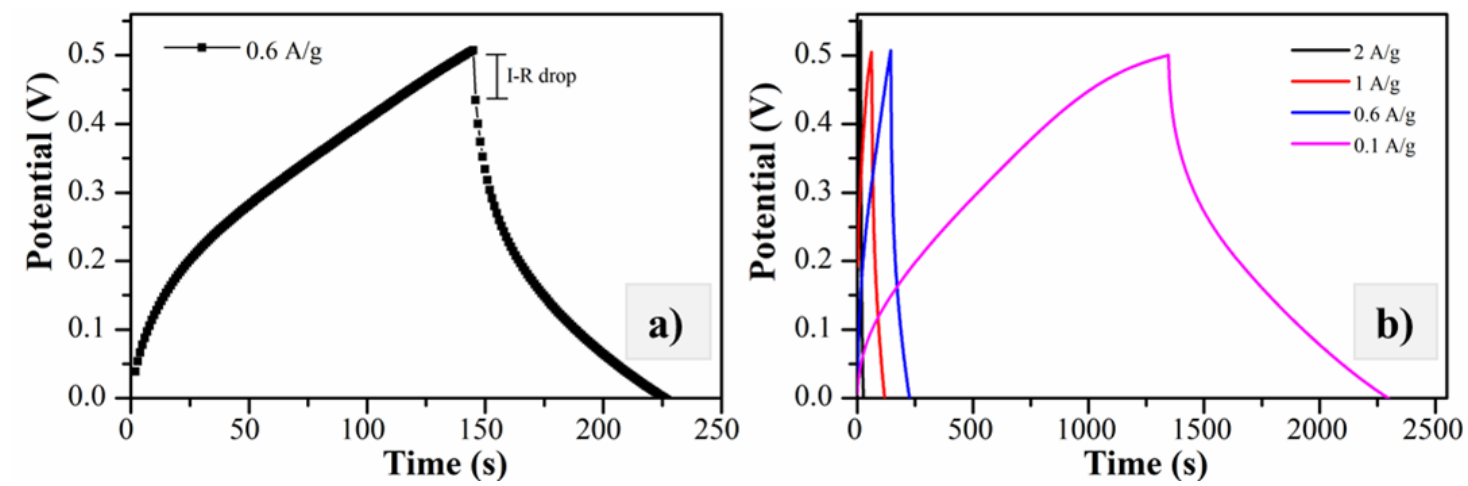

Figure 50. Galvanostatic charge-discharge curve of $\mathrm{MnOx}-\mathrm{D} / \mathrm{CP}$ with $0.6 \mathrm{~A} / \mathrm{g}$ current density (a) and different current densities such as $2 \mathrm{~A} / \mathrm{g}, 1 \mathrm{~A} / \mathrm{g}, 0.6 \mathrm{~A} / \mathrm{g}$ and $0.1 \mathrm{~A} / \mathrm{g}(\mathrm{b})$.

The specific capacitance calculated from equation (19) and the values were summarized in Table 14. From the galvanostatic charge-discharge measurement specific capacities of the MnOx-D/CP were ranging between $195.83 \mathrm{~F} / \mathrm{g}-68.75 \mathrm{~F} / \mathrm{g}$ at current density $0.1 \mathrm{~A} / \mathrm{g}-2 \mathrm{~F} / \mathrm{g}$, those results were similar to the values calculated from cyclic voltammetry.

$$
\mathrm{Cp}=\frac{I * \Delta t}{m * \Delta V}
$$

Table 14. The specific capacitance of the $\mathrm{MnO}_{\mathrm{x}}-\mathrm{D} / \mathrm{CP}$ from the galvanostatic charge-discharge

\begin{tabular}{cc}
\multicolumn{2}{c}{ measurement. } \\
\hline Current density, A/g & Specific capacitance, F/g \\
\hline 0.1 & 195.83 \\
0.6 & 153.48 \\
1 & 147.36 \\
2 & 68.75 \\
\hline
\end{tabular}

\subsubsection{Electrochemical impedance spectroscopy analysis}

Electrochemical impedance spectroscopy (EIS) analysis was performed with applied frequency $10,000 \mathrm{~Hz}$ and $0.001 \mathrm{~Hz}$ for the working electrode (CP and MnOx-D/CP) in a threeelectrode cell system. The Nyquist plot of the bare CP electrode is shown in Figure 51a. The resistance of the $\mathrm{MnOx}-\mathrm{D} / \mathrm{CP}$ electrode was much lower than resistance due to conductivity enhancement [131] in Figure 51b. The Nyquist plot of the MnOx-CP electrode was separated into two distinct regions:

- One lower-frequency region where the slope is close to linear at a 45-degree slope similarly to a typical supercapacitor electrode. This 45-degree slope linear region is called the porous region [245]. The ions can penetrate the pores, which can be modelled by a distributed 
resistance EDR (electrolyte distributed resistance), as the electrolyte diffuses into the electrode.

- The other region is in the higher-frequency domain where the semi curve occurred $\left(\mathrm{R}_{\mathrm{ct}}{ }^{-}\right.$ charge transfer resistance). The Low-frequency region starts at the beginning of the semicircle ( $\mathrm{R}_{\mathrm{s}}$-series resistance) in the high-frequency region corresponds to the resistances of the electrolyte solution was about 5 ohms. The observed $R_{\mathrm{ct}}$ value was $16 \mathrm{ohms}$ which considered decent capacitance property for an electrode [246].
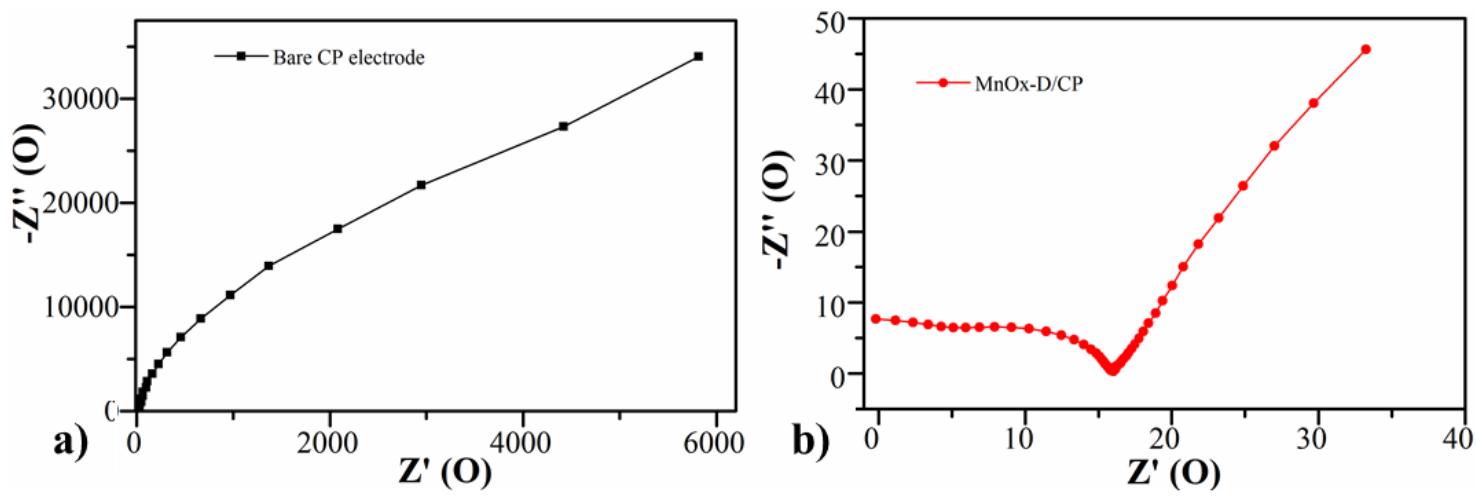

Figure 51. Nyquist plot of the bare carbon electrode (a) and MnOx-D/CP electrode (b).

Figure 52a shows the Bode plot of the $\mathrm{MnOx}-\mathrm{D} / \mathrm{CP}$, where the frequency versus real impedance is displayed. The frequency versus phase (degree) plot is presented in Figure 52b. The phase angle at the low-frequency region (below $\sim 0.1 \mathrm{~Hz}$ ) was about $60^{\circ}$ which indicate the capacitive behavior [247], shown in the inset of Figure 52b.
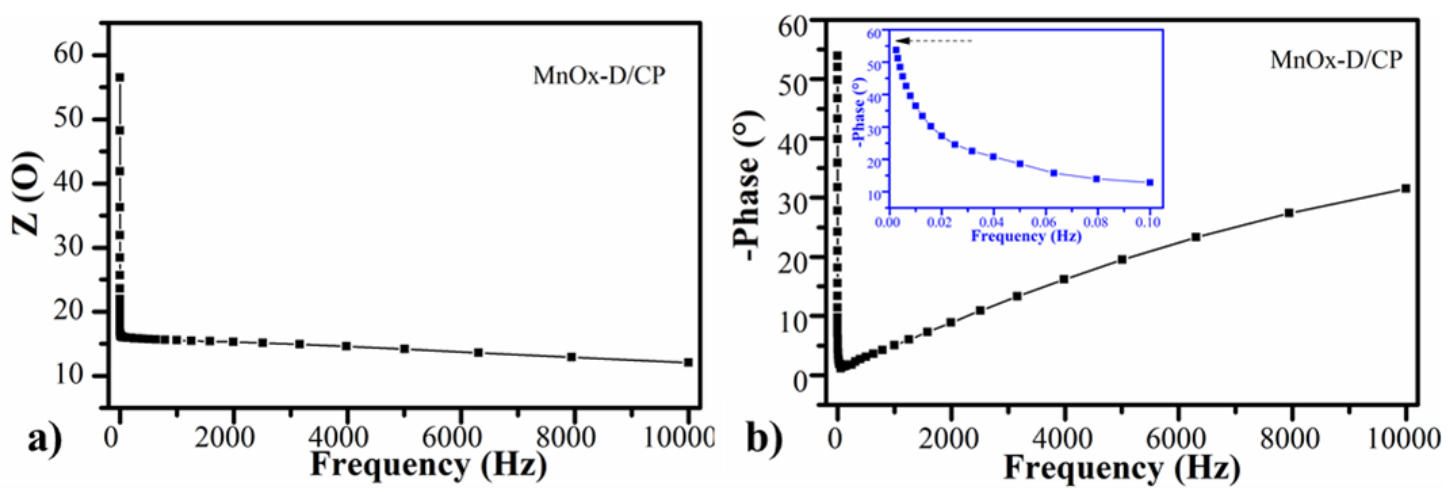

Figure 52. Bode plot of the MnOx-D/CP electrode the frequency versus real impedance (a) and phase degree (b). 


\section{Conclusion}

I. A simple method was developed for the synthesis of large specific surface area birnessite with or without interlayer copper cations. The method resulted in small, nanoparticle-like morphology and significant specific surface area (from $21.6 \mathrm{~m}^{2} / \mathrm{g}$ to $77.8 \mathrm{~m}^{2} / \mathrm{g}$ ) as well. The interlayer distance expansion revealed by XRD, HR-TEM, EDS characterization techniques, which can be attributed to the bigger size of the copper-ions as well as the higher amount of total interlayer cations. It was experimentally proven that the incorporation of copper ions enhanced the activity of birnessite structure resulting in an improved electron transfer number $(3.6>3.4)$ and higher electrochemical stability during the ORR test $(95>87 \%$ retention after 10,000-seconds of measurement). It was shown that the oxidation state ratio of $\mathrm{Mn}^{3+} / \mathrm{Mn}^{4+}$ in birnessite structure played important role in ORR catalytic activity, and the intercalated copper ion increased the $\mathrm{Mn}^{3+}$ ratio and stabilized its charge transfer characteristics. Also, the smaller particle size is boosting the activity owing to the larger surface-to-bulk ratio and numerous surface defects. These results prove that the synthesized Birnessite samples show great promise as an efficient, cheap, noble-metal-free electrochemical catalyst.

II. A novel mechanochemical route for nanostructured manganese oxide synthesis was demonstrated for the first time. It can be easily scaled up for industrial applications. The shape, porosity, specific surface area, as well as the ratio of the different oxidation states of the $\mathrm{Mn}$-ion in the structure, could be tuned by the milling parameters. Metal-loaded $(\mathrm{Pt}, \mathrm{Cu})$ $\mathrm{MnO}_{\mathrm{x}}$ structures were also prepared with the same one-pot technique and all the samples were tested in the $\mathrm{CO}_{2}$ hydrogenation reaction. First, we studied the effect of milling speed for pure samples milled in different milling speed (200, 450, $600 \mathrm{rpm})$. M600 catalysts showed the highest $\mathrm{CO}_{2}$ consumption rate $\left(\sim 20.000 \mathrm{nmol} \cdot \mathrm{g}^{-1} \cdot \mathrm{s}^{-1}\right)$ followed by M450 $\left(17.500 \mathrm{nmol} \cdot \mathrm{g}^{-1} \cdot \mathrm{s}^{-1}\right)$. Both M600 and M450 were almost two times more active compared to the catalyst milled at $200 \mathrm{rpm}\left(\sim 10.000 \mathrm{nmol} \cdot \mathrm{g}^{-1} \cdot \mathrm{s}^{-1}\right)$ at $873 \mathrm{~K}$. The high catalytic activity of manganese-oxide milled at higher speeds can be attributed to the high specific surface area and porosity as well as the differences in the crystal structure and oxidation state of the manganese ions. Second, we studied the effect of one-pot loading of metal $(\mathrm{Pt}, \mathrm{Cu})$. The catalytic activity at $673 \mathrm{~K}$ could be significantly enhanced by adding metal into the manganese-oxide structure - 12-13 and $\sim 2.5$ times upon the addition of platinum and copper, respectively. This activity enhancement; however, disappeared at a higher temperature $(873 \mathrm{~K})$. This phenomenon shows that temperature plays a vital role in the activity of the manganese oxide-based catalysts due to changes in the crystal structure and oxidation state of manganese ion besides the advantage provided by the higher surface area and porosity. It also reveals that expensive noble metal platinum can be replaced by copper 
since they show similar catalytic activity at a higher temperature (873K). Third, we studied Pt incorporation. Lacking significant differences in catalytic activities on the incorporation of Pt into the M600 catalyst, in various ways (one-pot synthesis, incipient wetness impregnation as well as loading of pre-synthesized $5 \mathrm{~nm}$ Pt nanoparticles by ultrasonication) verified the idea that the main working surface of these kinds of catalysts was based on the manganese oxide. Fourth, we studied the selectivity toward methane. In the case of the M600(Pt-milled) catalyst produced by the one-pot milling process, methane formation was significant compared to pure and $\mathrm{Cu}$-loaded catalysts prepared using different milling speeds. The result shows that, although the catalytic activity is not profoundly influenced by the metal -loading, the $\mathrm{Pt} / \mathrm{MnO}_{\mathrm{x}}$ interphase is crucial in the methane selectivity. Furthermore, it was found that the Pt-loaded manganese- oxide prepared by the one-pot synthesis has 1.5-2 times higher selectivity towards methane than the Pt-loaded $\mathrm{MnO}_{\mathrm{x}}$ catalyst synthesized by either wet impregnation or size-controlled Pt nanoparticle sonication/deposition. Through this observation, the formation of a unique $\mathrm{Pt} / \mathrm{MnO}_{\mathrm{x}}$ interface during the milling process was proven.

III. According to our results, the local mineral pyrolusite (originated from Úrkút, Hungary) could be used directly as a precursor for supercapacitor electrode synthesis. The wet milling process decreased the mineral size from a few $\mathrm{mm}$ to hundreds of nanometers, which improved the dissolution rate of manganese dioxide under eco-friendly (biodegradable) oxalic acid. Electrophoretic and electrochemical deposition took place in a two-electrode cell with carbon paper electrodes. In the final step electrophoretic deposition was successfully applied in a two-electrode cell to deposit nanostructured $\mathrm{MnO}_{\mathrm{x}}$ onto the carbon paper electrode. The electrochemical characteristic of the electrode was tested in a threeelectrode cell system. The specific capacitance of the electrode obtained from CV measurement varied between $68-119 \mathrm{~F} / \mathrm{g}$, and it depended upon the applied scan rates. The galvanostatic charge-discharge measurement revealed that the prepared manganese oxide electrode had the fast charge-discharge ability, and the specific capacitance ranged between 68-195 F/g at different current densities, which is in good agreement with the results obtained from the CV method. The specific capacitance of the electrode is comparable to analytical grade $\mathrm{MnOx}$ electrodes without polymer binders or conductive additives, even higher than some reported values in literature. EIS result also showed that the capacitive nature of the electrode. Further research is warranted on different methods to decrease the variance in capacitance for the supercapacitors, like heat treatment or decrease deposition time and thickness of the deposited material for example. We hope that our report paves the way for cost-effective mass production of future energy storage devices from manganese minerals directly. 


\section{Összefoglalás}

I. Kifejlesztettünk egy egyszerü módszert nagy fajlagos felületü, rétegközi réz kationokat tartalmazó és nem tartalmazó birnessit szintézisére. A módszer nanorészecskeszerü morfológiát és jelentős fajlagos felületet $\left(21,6 \mathrm{~m}^{2} / \mathrm{g}\right.$-tól 77,8 m²/g-ig) eredményezett. A rétegközi távolság növekedése az XRD, HR-TEM és EDS karakterizálási módszerek alapján kapcsolatot mutatott a réz ionok nagyobb méretével és a rétegközi kationok nagyobb mennyiségével is. Kísérletesen bizonyítottuk, hogy a réz kationok beépülése növelte a birnessit katalitikus aktivitását, amely nagyobb elektron transzfer számot $(3,6>3,4)$ és az ORR tesztek során nagyobb elektrokémiai stabilitást $\left(95>87 \%\right.$ retenció $10^{*} 000$ másodpercnyi mérés után) eredményezett. Kimutattuk, hogy a $\mathrm{Mn}^{3+} / \mathrm{Mn}^{4+}$ oxidációs állapotok aránya a birnessit szerkezetben fontos szerepet játszik az ORR katalitikus aktivitás szempontjából, és a réz kationok beépülése növelte a $\mathrm{Mn}^{3+}: \mathrm{Mn}^{4+}$ arányt és stabilizálta a töltésátviteli jellemzőket. Ugyanígy, a kisebb részecskeméret növeli az aktivitást a nagyobb felület-térfogat aránynak és a számos felületi hibának köszönhetően. Ezek az eredmények bizonyítják, hogy az előállított birnessit minták nagyon ígéretesnek mutatkoznak hatékony, olcsó, nemesfém-mentes elektrokémiai katalizátorként.

II. Elsőként mutattunk be egy új mechanokémiai útvonalat nanoszerkezetű mangán-oxid ellóállitására. A módszer könnyen skálázható ipari alkalmazásokhoz. Az alak, a porozitás és a fajlagos felület, a Mn-ionok különböző oxidációs állapotainak arányához hasonlóan a szerkezetben finomhangolható az örlési paraméterekkel. Fémmel adalékolt $(\mathrm{Pt}, \mathrm{Cu}) \mathrm{MnO}_{\mathrm{x}}$ szerkezeteket szintén elöállítottunk egyedényes technikával és az összes mintát teszteltük a $\mathrm{CO}_{2}$ hidrogénezési reakcióban. Elöször vizsgáltuk az örlési sebesség hatását a tiszta mintákon, amiket különböző sebességgel őröltünk (200, 450, 600 rpm). Az M600-as katalizátor mutatta a legnagyobb $\mathrm{CO}_{2}$ fogyási arányt $\left(\sim 20^{\circ} 000 \mathrm{nmol} \cdot \mathrm{g}^{-1} \cdot \mathrm{s}^{-1}\right)$, amit az M450-es követett $\left(17^{\circ} 500\right.$ $\left.\mathrm{nmol} \cdot \mathrm{g}^{-1} \cdot \mathrm{s}^{-1}\right)$. Mind az M600-as és az M450-es majdnem kétszer aktívabb volt a $200 \mathrm{rpm}$-en örölt katalizátorhoz $\left(\sim 10^{\circ} 000 \mathrm{nmol} \cdot \mathrm{g}^{-1} \cdot \mathrm{s}^{-1}\right)$ viszonyítva $873 \mathrm{~K}$-en. A magasabb sebességen őrölt mangán-oxid nagyobb katalitikus aktivitása a nagyobb fajlagos felületnek és a porozitásnak, emellett a kristályszerkezetbeli különbözőségeknek és a mangán ionok oxidációs állapotának tulajdoníthatók. Másrészt, megvizsgáltuk fémek (Pt, $\mathrm{Cu})$ adagolásának hatását az egyedényes szintézisre A katalitikus aktivitás 673 K-en jelentősen növelhető fémek mangán-oxid szerkezetbe való beépítésével - 12-13-szorosára platina és 2,5-szeresére réz hozzáadásával. Ez az aktivitásnövekedés azonban eltünik magasabb hőmérsékleten ( $873 \mathrm{~K})$. Ez a jelenség megmutatja, hogy a hőmérséklet létfontosságú szerepet játszik a mangán-oxidon alapuló katalizátorok aktivitásában a kristályszerkezetbeli változások és a mangán ionok oxidációs állapota miatt, a nagyobb felületi feszültség és porozitás nyújtotta előnyök mellett. Ebböl az is kiderül, hogy a drága nemesfém platinát rézre cserélhetjük, hiszen hasonló katalitikus aktivitást mutatnak 
magasabb hőmérsékleten ( $873 \mathrm{~K})$. Harmadrészt, vizsgáltuk a Pt beépülést. A katalitikus aktivitás jelentős mértékủ változásának hiánya Pt különböző módszerekkel (egyedényes szintézis, kezdődő nedvességig történő impregnálás és előre szintetizált $5 \mathrm{~nm}$-es Pt adagolása ultrahangos szonikálással) történő beépítésének következtében az M600-as katalizátorba bizonyítja, hogy a legfontosabb ezekben a típusú katalizátorokban a mangán-oxid felület. Negyedrészt, vizsgáltuk a metán szelektivitást. Az M600-as (Pt-val őrölt), egyedényes őrléssel előállított katalizátor esetében a metánképződés jelentős volt a tiszta és a Cu-zel őrölt katalizátorokhoz képest, különböző őrlési sebességek esetén. Az eredmények azt mutatták, hogy habár a katalitikus aktivitást nem befolyásolta nagymértékben a fémek hozzáadása, a Pt/MnOx interfész kiemelkedő jelentőségủ a metán szelektivitás tekintetében. Továbbá azt találtuk, hogy a Pt-val adalékolt egyedényes módszerrel előállított mangán-oxid 1,5-2-szeres metán szelektivitást mutatott a nedves impregnálással és a kontrollált méretü Pt nanorészecskék szonikálással/depozícióval való hozzáadásával előállított Pt tartalmú MnOx katalizátorokhoz képest. Ezzel a megfigyeléssel bizonyítottuk egy egyedi Pt/MnOx interfész kialakulását az őrlési folyamat során.

III. Az eredményeink alapján a helyben fellelhető ásvány, a piroluzit (származási hely: Úrkút, Magyarország) közvetlenül használható prekurzorként szuperkondenzátor elektród előállításakor. A nedves őrlés folyamata csökkentette az ásvány méretét néhány mm-röl néhány száz nanométerre, amely javította a mangán-dioxid oldódását környezetbarát (biológiailag lebomló) oxálsavban. Az elektroforetikus és elektrokémiai leválasztás egy kételektródos cellában zajlott le, szénpapír elektród alkalmazásával. Az utolsó lépésben elektroforetikus leválasztással sikeresen állítottunk elő nanoszerkezetü MnOx-ot egy kételektródos cellában szénpapír felületére. Az elektód elektrokémiai tulajdonságait egy háromelektródos cellában vizsgáltuk. Az elektród fajlagos kapacitása, amelyet CV mérésekből határoztuk meg 68 és 119 F/g között változott és függött a pásztázási sebességtől. A galvanosztatikus töltés-kisütés vizsgálatok megmutatták, hogy az előállított mangán-oxid elektród gyors töltés-kisütési képességgel rendelkezik és a fajlagos kapacitás 68-195 F/g között változott különböző áramsürüségek esetén, ami jó egyezést mutat a CV eredményekkel. Az elektród fajlagos kapacitása összemérhető volt az analitikai tisztaságú MnOx elektródéval, polimer kötőanyagok és vezetőképes adalékok hozzáadása nélkül, néhány esetben még az irodalomban bemutatott értékeknél is magasabbnak bizonyult. Az EIS mérések megmutatták az elektród kapacitív természetét. További kutatásra van szuikség a különböző módszerek esetében, hogy a szuperkondenzátorok kapacitásbeli különbségeit csökkenteni tudjuk, például hőkezelés, vagy a leválasztási idő csökkentése révén, illetve a leválasztott anyag vastagságának módosításával. Azt reméljük, hogy a kutatásunk kikövezi az utat jövőbeli, közvetlenül mangán ásványokból elöállított energiatároló eszközök költséghatékony tömeggyártásának irányába. 


\section{References and notes}

[1] N. Abas, A. Kalair, N. Khan, Review of fossil fuels and future energy technologies, Futures. 69 (2015) 31-49. https://doi.org/10.1016/j.futures.2015.03.003.

[2] The International Energy Agency, (n.d.). https://www.iea.org/data-andstatistics/?country=WORLD\&fuel=Energy consumption\&indicator=TotElecCons.

[3] P.K. Sarangi, S. Nanda, P. Mohanty, Recent advancements in biofuels and bioenergy utilization, 2018. https://doi.org/10.1007/978-981-13-1307-3.

[4] Y. Gorlin, Development of manganese oxide based catalysts for the oxygen reduction and oxygen evolution reactions, Stanford University, 2012.

[5] L. Schirone, F. Pellitteri, Energy policies and sustainable management of energy sources, Sustain. 9 (2017). https://doi.org/10.3390/su9122321.

[6] M.E. Mann, False hope, Sci. Am. 310 (2014) 78-81. https://doi.org/10.1038/scientificamerican0414-78.

[7] N.S. Lewis, D.G. Nocera, Powering the planet: Chemical challenges in solar energy utilization, Proc. Natl. Acad. Sci. 103 (2006) 15729-15735. https://doi.org/10.1073/pnas.0603395103.

[8] D. Bratt, Catalytic CO2 Hydrogenation - Literature Review : Technology Development since 2014, (2016).

[9] R. Heinberg, D. Fridley, The end of cheap coal, Nature. 468 (2010) 367-369. https://doi.org/10.1038/468367a.

[10] D. Gielen, F. Boshell, D. Saygin, M.D. Bazilian, N. Wagner, R. Gorini, The role of renewable energy in the global energy transformation, Energy Strateg. Rev. 24 (2019) 38-50. https://doi.org/10.1016/j.esr.2019.01.006.

[11] H.O. Bergesen, G. Parmann, O.B. Thommessen, Convention on the Conservation of Migratory Species of Wild Animals (CMS), Yearb. Int. Coop. Environ. Dev. 1998-99. (2019) 154-155. https://doi.org/10.4324/9781315066547-40.

[12] A. Coralli, B.J.M. Sarruf, P.E. V. de Miranda, Luigi Osmieri, S. Specchia, N.Q. Minh, Chapter 2 Fuel Cells, Elsevier Inc., 2019. https://doi.org/10.1016/B978-0-12-814251-6.00002-2.

[13] I. Das, M.T. Noori, G.D. Bhowmick, M.M. Ghangrekar, Synthesis of bimetallic iron ferrite $\mathrm{Co} 0.5 \mathrm{Zn} 0.5 \mathrm{Fe} 2 \mathrm{O} 4$ as a superior catalyst for oxygen reduction reaction to replace noble metal catalysts in microbial fuel cell, Int. J. Hydrogen Energy. 43 (2018) 19196-19205. https://doi.org/10.1016/j.ijhydene.2018.08.113.

[14] M.K. Mahapatra, P. Singh, Fuel Cells. Energy Conversion Technology., 2013. https://doi.org/10.1016/B978-0-08-099424-6.00024-7.

[15] E.R. Gonzalez, S. Srinivasan, Electrochemistry of fuel cells for transportation applications, Int. J. Hydrogen Energy. 9 (1984) 215-218. https://doi.org/10.1016/0360-3199(84)90121-6.

[16] F. Tzorbatzoglou, A. Brouzgou, S. Jing, Y. Wang, S. Song, P. Tsiakaras, Oxygen reduction and hydrogen oxidation reaction on novel carbon supported PdxIry electrocatalysts, Int. J. Hydrogen Energy. 43 (2018) 11766-11777. https://doi.org/10.1016/j.ijhydene.2018.02.071.

[17] F. Perera, Pollution from fossil-fuel combustion is the leading environmental threat to global pediatric health and equity: Solutions exist, Int. J. Environ. Res. Public Health. 15 (2018). https://doi.org/10.3390/ijerph15010016.

[18] K. Keramidas, S. Tchung-Ming, A.R. Diaz-Vazquez, M. Weitzel, T. Vandyck, J. Després, A. Schmitz, L. Rey Los Santos, K. Wojtowicz, B. Schade, B. Saveyn, A. Soria-Ramirez, Global Energy and Climate Outlook 2018: Sectoral mitigation options towards a low-emissions economy, 2018. https://doi.org/10.2760/67475.

[19] C.F. Schleussner, J. Rogelj, M. Schaeffer, T. Lissner, R. Licker, E.M. Fischer, R. Knutti, A. Levermann, K. Frieler, W. Hare, Science and policy characteristics of the Paris Agreement temperature goal, Nat. Clim. Chang. 6 (2016) 827-835. https://doi.org/10.1038/nclimate3096.

[20] D.M. D'Alessandro, B. Smit, J.R. Long, Carbon dioxide capture: Prospects for new materials, Angew. Chemie - Int. Ed. 49 (2010) 6058-6082. https://doi.org/10.1002/anie.201000431.

[21] G.A. Olah, T. Mathew, A. Goeppert, G.K.S. Prakash, Difference and Significance of Regenerative Versus Renewable Carbon Fuels and Products, Top. Catal. 61 (2018) 522-529. https://doi.org/10.1007/s11244-018-0964-8.

[22] J. Wei, Q. Ge, R. Yao, Z. Wen, C. Fang, L. Guo, H. Xu, J. Sun, Directly converting CO2 into a gasoline fuel, Nat. Commun. 8 (2017) 15174. https://doi.org/10.1038/ncomms15174.

[23] C. Xie, C. Chen, Y. Yu, J. Su, Y. Li, G.A. Somorjai, P. Yang, Tandem Catalysis for CO2 Hydrogenation to C2 -C4 Hydrocarbons, Nano Lett. 17 (2017) 3798-3802.

https://doi.org/10.1021/acs.nanolett.7b01139. 
[24] M. Zhu, Q. Ge, X. Zhu, Catalytic Reduction of CO2 to CO via Reverse Water Gas Shift Reaction: Recent Advances in the Design of Active and Selective Supported Metal Catalysts, Trans. Tianjin Univ. 26 (2020) 172-187. https://doi.org/10.1007/s12209-020-00246-8.

[25] J. Martínez, E. Hernández, S. Alfaro, R.L. Medina, G.V. Aguilar, E. Albiter, M.A. Valenzuela, High selectivity and stability of nickel catalysts for CO2 Methanation: Support effects, Catalysts. 9 (2019). https://doi.org/10.3390/catal9010024.

[26] H. Yang, C. Zhang, P. Gao, H. Wang, X. Li, L. Zhong, W. Wei, Y. Sun, A review of the catalytic hydrogenation of carbon dioxide into value-added hydrocarbons, Catal. Sci. Technol. 7 (2017) 4580-4598. https://doi.org/10.1039/c7cy01403a.

[27] F. Studt, I. Sharafutdinov, F. Abild-Pedersen, C.F. Elkjær, J.S. Hummelshøj, S. Dahl, I. Chorkendorff, J.K. Nørskov, Discovery of a Ni-Ga catalyst for carbon dioxide reduction to methanol, Nat. Chem. 6 (2014) 320-324. https://doi.org/10.1038/nchem.1873.

[28] X. Du, D. Zhang, L. Shi, R. Gao, J. Zhang, Morphology dependence of catalytic properties of $\mathrm{Ni} / \mathrm{CeO} 2$ nanostructures for carbon dioxide reforming of methane, J. Phys. Chem. C. 116 (2012) 10009-10016. https://doi.org/10.1021/jp300543r.

[29] D. Shi, R. Wojcieszak, S. Paul, E. Marceau, Ni promotion by fe: What benefits for catalytic hydrogenation?, Catalysts. 9 (2019). https://doi.org/10.3390/catal9050451.

[30] R. Xiong, S. Ma, H. Li, F. Sun, J. Li, Toward a Safer Battery Management System: A Critical Review on Diagnosis and Prognosis of Battery Short Circuit, IScience. 23 (2020) 1-18. https://doi.org/10.1016/j.isci.2020.101010.

[31] X. Hu, L. Xu, X. Lin, M. Pecht, Battery Lifetime Prognostics, Joule. 4 (2020) 310-346. https://doi.org/10.1016/j.joule.2019.11.018.

[32] Y. Ko, M. Kwon, W.K. Bae, B. Lee, S.W. Lee, J. Cho, Flexible supercapacitor electrodes based on real metal-like cellulose papers/639/4077/4079/4105/639/301/299/1013 article, Nat. Commun. 8 (2017) 1-10. https://doi.org/10.1038/s41467-017-00550-3.

[33] Y. Huang, M. Zhong, Y. Huang, M. Zhu, Z. Pei, Z. Wang, Q. Xue, X. Xie, C. Zhi, A selfhealable and highly stretchable supercapacitor based on a dual crosslinked polyelectrolyte, Nat. Commun. 6 (2015). https://doi.org/10.1038/ncomms10310.

[34] G.S. Gund, D.P. Dubal, N.R. Chodankar, J.Y. Cho, P. Gomez-Romero, C. Park, C.D. Lokhande, Low-cost flexible supercapacitors with high-energy density based on nanostructured $\mathrm{MnO} 2$ and Fe2O3 thin films directly fabricated onto stainless steel, Sci. Rep. 5 (2015) 1-13. https://doi.org/10.1038/srep12454.

[35] M. Winter, R.J. Brodd, What are batteries, fuel cells, and supercapacitors?, Chem. Rev. 104 (2004) 4245-4269. https://doi.org/10.1021/cr020730k.

[36] A. Sato, TAIYO YUDEN Lithium Ion Capacitors : An Effective EDLC Replacement TAIYO YUDEN Lithium Ion Capacitors : The Ultimate EDLC Replacement, (2014). http://electronicdesign.com/site-files/electronicdesign.com/files/uploads/2014/04/LIC-WhitePaper_Final.pdf.

[37] C.-C. Hu, W.-C. Chen, K.-H. Chang, How to Achieve Maximum Utilization of Hydrous Ruthenium Oxide for Supercapacitors, J. Electrochem. Soc. 151 (2004) A281. https://doi.org/10.1149/1.1639020.

[38] C.D. Lokhande, D.P. Dubal, O.S. Joo, Metal oxide thin film based supercapacitors, Curr. Appl. Phys. 11 (2011) 255-270. https://doi.org/10.1016/j.cap.2010.12.001.

[39] G. Jian, Y. Xu, L.C. Lai, C. Wang, M.R. Zachariah, Mn3O4 hollow spheres for lithium-ion batteries with high rate and capacity, J. Mater. Chem. A. 2 (2014) 4627-4632. https://doi.org/10.1039/c4ta00207e.

[40] G. Grasselly, É. Klivényi, Concerning the thermal properties of the manganese oxides of higher valencies, Acta Mineral. 9 (1956) 15-32.

[41] F. Aguado, F. Rodriguez, P. Núñez, Pressure-induced Jahn-Teller suppression and simultaneous high-spin to low-spin transition in the layered perovskite CsMn F4, Phys. Rev. B - Condens. Matter Mater. Phys. 76 (2007). https://doi.org/10.1103/PhysRevB.76.094417.

[42] R.M. Freitas, T.A.G. Perilli, A.C.Q. Ladeira, Oxidative precipitation of manganese from acid mine drainage by potassium permanganate, J. Chem. 2013 (2013). https://doi.org/10.1155/2013/287257.

[43] T. Sawyer, ) r ) r, 25 (1985) 164-176.

[44] A. Muñoz-Páez, Transition metal oxides: Geometric and electronic structures - Introducing solid state topics in inorganic chemistry courses, J. Chem. Educ. 71 (1994) 381-387. https://doi.org/10.1021/ed071p381.

[45] L.H.P. Jones, A.A. Milne, Birnessite, a new manganese oxide mineral from Aberdeenshire, Scotland, Mineral. Mag. J. Mineral. Soc. 31 (1956) 283-288. 
https://doi.org/10.1180/minmag.1956.031.235.01.

[46] B.J. Deibert, J. Zhang, P.F. Smith, K.W. Chapman, S. Rangan, D. Banerjee, K. Tan, H. Wang, N. Pasquale, F. Chen, K.B. Lee, G.C. Dismukes, Y.J. Chabal, J. Li, Surface and Structural Investigation of a MnOx Birnessite-Type Water Oxidation Catalyst Formed under Photocatalytic Conditions, Chem. - A Eur. J. 21 (2015) 14218-14228. https://doi.org/10.1002/chem.201501930.

[47] X. Zhang, P. Yu, H. Zhang, D. Zhang, X. Sun, Y. Ma, Rapid hydrothermal synthesis of hierarchical nanostructures assembled from ultrathin birnessite-type $\mathrm{MnO} 2$ nanosheets for supercapacitor applications, Electrochim. Acta. 89 (2013) 523-529.

https://doi.org/10.1016/j.electacta.2012.11.089.

[48] H. Yin, Y. Liu, L.K. Koopal, X. Feng, S. Chu, M. Zhu, F. Liu, High Co-doping promotes the transition of birnessite layer symmetry from orthogonal to hexagonal, Chem. Geol. 410 (2015) 12-20. https://doi.org/10.1016/j.chemgeo.2015.05.015.

[49] I.G. McKendry, A.C. Thenuwara, S.L. Shumlas, H. Peng, Y. V. Aulin, P.R. Chinnam, E. Borguet, D.R. Strongin, M.J. Zdilla, Systematic Doping of Cobalt into Layered Manganese Oxide Sheets Substantially Enhances Water Oxidation Catalysis, Inorg. Chem. 57 (2018) 557-564. https://doi.org/10.1021/acs.inorgchem.7b01592.

[50] A.C. Thenuwara, S.L. Shumlas, N.H. Attanayake, Y. V. Aulin, I.G. McKendry, Q. Qiao, Y. Zhu, E. Borguet, M.J. Zdilla, D.R. Strongin, Intercalation of Cobalt into the Interlayer of Birnessite Improves Oxygen Evolution Catalysis, ACS Catal. 6 (2016) 7739-7743. https://doi.org/10.1021/acscatal.6b01980.

[51] F.T. Ling, P.J. Heaney, J.E. Post, X. Gao, Transformations from triclinic to hexagonal birnessite at circumneutral $\mathrm{pH}$ induced through $\mathrm{pH}$ control by common biological buffers, Chem. Geol. 416 (2015) 1-10. https://doi.org/10.1016/j.chemgeo.2015.10.007.

[52] P.R. Garcês Gonçalves, H.A. De Abreu, H.A. Duarte, Stability, Structural, and Electronic Properties of Hausmannite (Mn3O4) Surfaces and Their Interaction with Water, J. Phys. Chem. C. 122 (2018) 20841-20849. https://doi.org/10.1021/acs.jpcc.8b06201.

[53] K.K. Turekian, N. Haven, K. Hans, W.M. Der Universitat, KARL K. TUREKIAN Dept. Geology, Yale University, New Haven, Conn. KARL HANS WEDEPOHL MineralogischeInstitut der Universitat, Gottingen, Germany Distribution of the Elements in Some Major Units of the Earth's Crust, America (NY). (1961) 175-192.

[54] G. Nádaská, J. Lesný, I. Michalík, Environmental aspect of manganese chemistry, Hungarian J. Sci. ENV-100702-A. (2010) 1-16.

[55] Manganese on Mars As an Indicator of Habitable Environments and a, 2019 (2019) 2019-2020.

[56] M. Fleischer, W.E. Richmond, The manganese oxide minerals a preliminary report?, Econ. Geol. 38 (1943) 269-286. https://doi.org/10.2113/gsecongeo.38.4.269.

[57] Hudson Institute of Mineralogy, Mineralogy, (n.d.). https://www.mindat.org/.

[58] E. Geology, Occurrence Where, 54 (1959) 1078-1094.

[59] The Manganese Ore Mineral Occurrences of Hungary *, (1951).

[60] M. Polgári, M. Szabó-Drubina, Z. Szbó, Theoretical model for Jurassic manganese mineralization in Central Europe, Úrkút, Hungary, Bull. Geosci. 79 (2004) 53-61. https://doi.org/10.3140/bull.geosci.2004.01.053.

[61] R.M. McKenzie, The Synthesis of Birnessite, Cryptomelane, and Some Other Oxides and Hydroxides of Manganese, Mineral. Mag. 38 (1971) 493-502. https://doi.org/10.1180/minmag.1971.038.296.12.

[62] A. Biswal, B.C. Tripathy, K. Sanjay, T. Subbaiah, M. Minakshi, Electrolytic manganese dioxide (EMD): A perspective on worldwide production, reserves and its role in electrochemistry, RSC Adv. 5 (2015) 58255-58283. https://doi.org/10.1039/c5ra05892a.

[63] S. Rodrigues, N. Munichandraiah, A.K. Shukla, A cyclic voltammetric study of the kinetics and mechanism of electrodeposition of manganese dioxide, J. Appl. Electrochem. 28 (1998) 12351241. https://doi.org/10.1023/A:1003472901760.

[64] P. Amrollahi, J.S. Krasinski, R. Vaidyanathan, L. Tayebi, D. Vashaee, Electrophoretic Deposition (EPD): Fundamentals and Applications from Nano- to Microscale Structures, in: M. Aliofkhazraei, A.S.H. Makhlouf (Eds.), Handb. Nanoelectrochemistry Electrochem. Synth. Methods, Prop. Charact. Tech., Springer International Publishing, Cham, 2016: pp. 561-591. https://doi.org/10.1007/978-3-319-15266-0_7.

[65] J. Li, I. Zhitomirsky, Electrophoretic deposition of manganese oxide nanofibers, Mater. Chem. Phys. 112 (2008) 525-530. https://doi.org/10.1016/j.matchemphys.2008.05.086.

[66] C.Y. Chen, T.C. Chien, Y.C. Chan, C.K. Lin, S.C. Wang, Pseudocapacitive properties of carbon nanotube/manganese oxide electrode deposited by electrophoretic deposition, Diam. Relat. Mater. 18 (2009) 482-485. https://doi.org/10.1016/j.diamond.2008.10.032. 
[67] H.X. Kho, S. Bae, S. Bae, B.-W. Kim, J.S. Kim, Planetary Ball Mill Process in Aspect of Milling Energy, J. Korean Powder Metall. Inst. 21 (2014) 155-164.

https://doi.org/10.4150/KPMI.2014.21.2.155.

[68] C. Xu, S. De, A.M. Balu, M. Ojeda, R. Luque, Mechanochemical synthesis of advanced nanomaterials for catalytic applications, Chem. Commun. 51 (2015) 6698-6713. https://doi.org/10.1039/c4cc09876e.

[69] R.A. Buyanov, V. V. Molchanov, V. V. Boldyrev, Mechanochemical activation as a tool of increasing catalytic activity, Catal. Today. 144 (2009) 212-218.

https://doi.org/10.1016/j.cattod.2009.02.042.

[70] P. Baláž, Mechanochemistry in nanoscience and minerals engineering, 2008. https://doi.org/10.1007/978-3-540-74855-7.

[71] S. Ostovar, A. Franco, A.R. Puente-Santiago, M. Pinilla-de Dios, D. Rodríguez-Padrón, H.R. Shaterian, R. Luque, Efficient mechanochemical bifunctional nanocatalysts for the conversion of isoeugenol to vanillin, Front. Chem. 6 (2018) 1-7. https://doi.org/10.3389/fchem.2018.00077.

[72] V. V. Molchanov, R.A. Buyanov, Mechanochemistry of catalysts, Usp. Khim. 69 (2000) 490493. https://doi.org/10.1070/rc2000v069n05abeh000555.

[73] A. Gagrani, J. Zhou, T. Tsuzuki, Solvent free mechanochemical synthesis of MnO2for the efficient degradation of Rhodamine-B, Ceram. Int. 44 (2018) 4694-4698. https://doi.org/10.1016/j.ceramint.2017.12.050.

[74] H. Liu, K. Zhao, Asymmetric flow electrochemical capacitor with high energy densities based on birnessite-type manganese oxide nanosheets and activated carbon slurries, J. Mater. Sci. 51 (2016) 9306-9313. https://doi.org/10.1007/s10853-016-0177-0.

[75] A. Iyer, P. Dutta, S. Suib, Water Oxidation Catalysis using Amorphous Manganese Oxides, Octahedral Molecular Sieves (OMS-2), and Octahedral Layered (OL-1) Manganese Oxide Structures - The Journal of Physical Chemistry C (ACS Publications), J. Phys. Chem. C. 116 (2012) 6474-6483.

http://pubs.acs.org/doi/full/10.1021/jp2120737\%5Cnpapers2://publication/uuid/762BE9A2-93264D58-BBF1-1C3D18E56DC8.

[76] S. Anandan, B. Gnana Sundara Raj, G.J. Lee, J.J. Wu, Sonochemical synthesis of manganese (II) hydroxide for supercapacitor applications, Mater. Res. Bull. 48 (2013) 3357-3361. https://doi.org/10.1016/j.materresbull.2013.05.021.

[77] T. Prasad Yadav, R. Manohar Yadav, D. Pratap Singh, Mechanical Milling: a Top Down Approach for the Synthesis of Nanomaterials and Nanocomposites, Nanosci. Nanotechnol. 2 (2012) 22-48. https://doi.org/10.5923/j.nn.20120203.01.

[78] T.N. Afonasenko, O.A. Bulavchenko, O.A. Knyazheva, O.N. Baklanova, T.I. Gulyaeva, M. V. Trenikhin, S. V. Tsybulya, P.G. Tsyrul'nikov, Effect of the mechanical activation of a mixture of $\mathrm{MnCO} 3 \cdot \mathrm{mMn}(\mathrm{OH}) 2 \cdot \mathrm{nH} 2 \mathrm{O}$ and $\mathrm{AlOOH}$ as a stage of the preparation of a MnOx-Al2O3 catalyst on its phase composition and catalytic activity in CO oxidation, Kinet. Catal. 56 (2015) 359-368. https://doi.org/10.1134/S0023158415030015.

[79] O.A. Bulavchenko, T.N. Afonasenko, P.G. Tsyrul'nikov, O.A. Knyazheva, O.N. Baklanova, S. V. Tsybulya, $\mathrm{MnO}$ x $-\mathrm{A} 12 \mathrm{O} 3$ catalysts for deep oxidation prepared with the use of mechanochemical activation: The effect of synthesis conditions on the phase composition and catalytic properties, Kinet. Catal. 55 (2014) 639-648. https://doi.org/10.1134/S0023158414050048.

[80] R.A.B. Victor V.Molchanov, Vasily V.Goidin, Mechano-chemical Reactions at High Pressure of the Gas Phase, Chemistry (Easton). (2002) 133-140.

[81] Z. Sawlowicz, I. V Bacherikova, S.M. Shcherbakov, The Effect of Mechanochemical and Ultrasonic Treatments $\mathrm{CeO}_{2}-\mathrm{MoO}_{3}=1: 1$, (2019).

[82] R.A. Buyanov, V. V. Molchanov, V. V. Boldyrev, Mechanochemical activation for resolving the problems of catalysis, KONA Powder Part. J. 27 (2009) 38-54. https://doi.org/10.14356/kona.2009007.

[83] Z.J. Jiang, Z.H. Li, J.B. Yu, W.K. Su, Liquid-Assisted Grinding Accelerating: Suzuki-Miyaura Reaction of Aryl Chlorides under High-Speed Ball-Milling Conditions, J. Org. Chem. 81 (2016) 10049-10055. https://doi.org/10.1021/acs.joc.6b01938.

[84] S. Zhuang, E.S. Lee, L. Lei, B.B. Nunna, L. Kuang, W. Zhang, Synthesis of nitrogen-doped graphene catalyst by high-energy wet ball milling for electrochemical systems, Int. J. Energy Res. 40 (2016) 2136-2149. https://doi.org/10.1002/er.3595.

[85] V. Šepeĺak, Nanocrystalline materials prepared by homogeneous and heterogeneous mechanochemical reactions, Ann. Chim. Sci. Des Mater. 27 (2002) 61-76. https://doi.org/10.1016/S0151-9107(02)90015-2.

[86] V. V. Molchanov, R.A. Buyanov, Scientific grounds for the application of mechanochemistry to 
catalyst preparation, Kinet. Catal. 42 (2001) 406-415. https://doi.org/10.1023/A:1010465315877.

[87] L.C. Kingsland, Manganese electrowinning patent, Law Contemp. Probl. 13 (1948) 354.

[88] C.L.M.E.T. Al, July 15, 1969, (1969).

[89] M.B.J.G. Freitas, V.C. Pegoretti, M.K. Pietre, Recycling manganese from spent $\mathrm{Zn}-\mathrm{MnO} 2$ primary batteries, J. Power Sources. 164 (2007) 947-952.

https://doi.org/10.1016/j.jpowsour.2006.10.050.

[90] Z. Li, L. He, Z.W. Zhao, D. Wang, W. Xu, Recovery of Lithium and Manganese from Scrap LiMn2O4 by Slurry Electrolysis, ACS Sustain. Chem. Eng. 7 (2019) 16738-16746.

https://doi.org/10.1021/acssuschemeng.9b04127.

[91] C. Acharya, R.N. Kar, L.B. Sukla, V.N. Misra, Fungal leaching of manganese ore, Trans. Indian Inst. Met. 57 (2004) 501-508.

[92] Y. Zhang, Z. You, G. Li, T. Jiang, Manganese extraction by sulfur-based reduction roasting-acid leaching from low-grade manganese oxide ores, Hydrometallurgy. 133 (2013) 126-132.

https://doi.org/10.1016/j.hydromet.2013.01.003.

[93] Statista, (n.d.). https://www.statista.com/statistics/247615/global-production-of-manganese-ore/.

[94] O. Gajigo, E. Mutambatsere, E. Adjei, Manganese Industry Analysis: Implications for project finance, (2011) 28. https://www.afdb.org/fileadmin/uploads/afdb/Documents/Publications/WPS No 132 Manganese Industry Analysis doc.pdf.

[95] R. Siddall, Mineral pigments in archaeology: Their analysis and the range of available materials, Minerals. 8 (2018) 1-35. https://doi.org/10.3390/min8050201.

[96] W.F. Cannon, Worldwide Supply of and Demand for Manganese How Do We Ensure Adequate Supplies of Manganese for the Future?, USGS Miner. Resour. Progr. (2014) 3087.

http://minerals.usgs.gov/minerals/pubs/.

[97] J.W. Martin, Metals and alloys, Mater. Eng. (2006) 71-132.

https://doi.org/10.1533/9781845691608.2.71.

[98] Mineral prices, (n.d.). https://mineralprices.com/platinum-group-metals/.

[99] O.D. Ozinger, N, Ullmann's Encyclopedia of Industrial Chemistry, Wiley-VCH Verlag GmbH \& Co. KGaA, Weinheim, Germany, 2000. https://doi.org/10.1002/14356007.

[100] J. Wisniak, The History of Catalysis. From the Beginning to Nobel Prizes, Educ. Quim. 21 (2010) 60-69. https://doi.org/10.1016/S0187-893X(18)30074-0.

[101] A. Mukherjee, D. Milstein, Homogeneous Catalysis by Cobalt and Manganese Pincer Complexes, ACS Catal. 8 (2018) 11435-11469. https://doi.org/10.1021/acscatal.8b02869.

[102] H. Xu, N. Yan, Z. Qu, W. Liu, J. Mei, W. Huang, S. Zhao, Gaseous Heterogeneous Catalytic Reactions over Mn-Based Oxides for Environmental Applications: A Critical Review, Environ. Sci. Technol. 51 (2017) 8879-8892. https://doi.org/10.1021/acs.est.6b06079.

[103] M.. Paridah, A. Moradbak, A.. Mohamed, F. abdulwahab taiwo Owolabi, M. Asniza, S.H.. Abdul Khalid, We are IntechOpen, the world's leading publisher of Open Access books Built by scientists, for scientists TOP $1 \%$, Intech. i (2016) 13. https://doi.org/http://dx.doi.org/10.5772/57353.

[104] Q. Tang, L. Jiang, J. Liu, S. Wang, G. Sun, Effect of surface manganese valence of manganese oxides on the activity of the oxygen reduction reaction in alkaline media, ACS Catal. 4 (2014) 457-463. https://doi.org/10.1021/cs400938s.

[105] K.A. Stoerzinger, M. Risch, B. Han, Y. Shao-Horn, Recent Insights into Manganese Oxides in Catalyzing Oxygen Reduction Kinetics, ACS Catal. 5 (2015) 6021-6031. https://doi.org/10.1021/acscatal.5b01444.

[106] S. Sun, H. Miao, Y. Xue, Q. Wang, S. Li, Z. Liu, Oxygen reduction reaction catalysts of manganese oxide decorated by silver nanoparticles for aluminum-air batteries, Electrochim. Acta. 214 (2016) 49-55. https://doi.org/10.1016/j.electacta.2016.07.127.

[107] C.C. Wang, Z. Yu, X.T. Wang, B. Lin, Enhanced electrocatalytic performance of NiOx@MnOx@graphene for oxygen reduction and evolution reactions, Int. J. Hydrogen Energy. 43 (2018) 18992-19001. https://doi.org/10.1016/j.ijhydene.2018.08.073.

[108] F. Wu, B. Feng, W. Li, H. Liu, Y. Mei, W. Hu, Efficient oxygen reduction electrocatalysis on $\mathrm{Mn} 3 \mathrm{O} 4$ nanoparticles decorated $\mathrm{N}$-doped carbon with hierarchical porosity and abundant active sites, Int. J. Hydrogen Energy. 44 (2019) 26387-26395. https://doi.org/10.1016/j.ijhydene.2019.08.139.

[109] W. Wang, J. Geng, L. Kuai, M. Li, B. Geng, Porous Mn2O3: A Low-Cost Electrocatalyst for Oxygen Reduction Reaction in Alkaline Media with Comparable Activity to Pt/C, Chem. - A Eur. J. 22 (2016) 9909-9913. https://doi.org/10.1002/chem.201602078.

[110] S. Kosasang, N. Ma, P. Wuamprakhon, N. Phattharasupakun, T. Maihom, J. Limtrakul, M. Sawangphruk, Insight into the effect of intercalated alkaline cations of layered manganese oxides 
on the oxygen reduction reaction and oxygen evolution reaction, Chem. Commun. 54 (2018) 8575-8578. https://doi.org/10.1039/c8cc03775b.

[111] A.S. Ryabova, F.S. Napolskiy, T. Poux, S.Y. Istomin, A. Bonnefont, D.M. Antipin, A.Y. Baranchikov, E.E. Levin, A.M. Abakumov, G. Kéranguéven, E. V. Antipov, G.A. Tsirlina, E.R. Savinova, Rationalizing the Influence of the Mn(IV)/Mn(III) Red-Ox Transition on the Electrocatalytic Activity of Manganese Oxides in the Oxygen Reduction Reaction, Electrochim. Acta. 187 (2016) 161-172. https://doi.org/10.1016/j.electacta.2015.11.012.

[112] S. Sun, Y. Xue, Q. Wang, H. Huang, H. Miao, Z. Liu, Cerium ion intercalated MnO2nanospheres with high catalytic activity toward oxygen reduction reaction for aluminum-air batteries, Elsevier Ltd, 2018. https://doi.org/10.1016/j.electacta.2018.01.057.

[113] S. Sun, H. Miao, Y. Xue, Q. Wang, Q. Zhang, Z. Dong, S. Li, H. Huang, Z. Liu, High electrocatalytic activity of silver-doped manganese dioxide toward oxygen reduction reaction in aluminum-air battery, J. Electrochem. Soc. 164 (2017) F768-F774. https://doi.org/10.1149/2.0541707jes.

[114] Y.L. Cao, H.X. Yang, X.P. Ai, L.F. Xiao, The mechanism of oxygen reduction on MnO2catalyzed air cathode in alkaline solution, J. Electroanal. Chem. 557 (2003) 127-134. https://doi.org/10.1016/S0022-0728(03)00355-3.

[115] E. Ríos, S. Abarca, P. Daccarett, H. Nguyen Cong, D. Martel, J.F. Marco, J.R. Gancedo, J.L. Gautier, Electrocatalysis of oxygen reduction on CuxMn3-xO4 $(1.0 \leq \mathrm{x} \leq 1.4)$ spinel particles/polypyrrole composite electrodes, Int. J. Hydrogen Energy. 33 (2008) 4945-4954. https://doi.org/10.1016/j.ijhydene.2008.06.030.

[116] T.N. Lambert, D.J. Davis, W. Lu, S.J. Limmer, P.G. Kotula, A. Thuli, M. Hungate, G. Ruan, Z. Jin, J.M. Tour, Graphene-Ni- $\alpha-\mathrm{MnO} 2$ and $-\mathrm{Cu}-\alpha-\mathrm{MnO} 2$ nanowire blends as highly active nonprecious metal catalysts for the oxygen reduction reaction, Chem. Commun. 48 (2012) $7931-$ 7933. https://doi.org/10.1039/c2cc32971a.

[117] D.J. Davis, T.N. Lambert, J.A. Vigil, M.A. Rodriguez, M.T. Brumbach, E.N. Coker, S.J. Limmer, Role of $\mathrm{Cu}$-Ion doping in $\mathrm{Cu}-\alpha-\mathrm{MnO} 2$ nanowire electrocatalysts for the oxygen reduction reaction, J. Phys. Chem. C. 118 (2014) 17342-17350. https://doi.org/10.1021/jp5039865.

[118] L. Cao, Z. Zhao, Z. Liu, W. Gao, S. Dai, J. Gha, W. Xue, H. Sun, X. Duan, X. Pan, T. Mueller, Y. Huang, Differential Surface Elemental Distribution Leads to Significantly Enhanced Stability of PtNi-Based ORR Catalysts, Matter. 1 (2019) 1567-1580. https://doi.org/10.1016/j.matt.2019.07.015.

[119] F. Bertini, M. Glatz, N. Gorgas, B. Stöger, M. Peruzzini, L.F. Veiros, K. Kirchner, L. Gonsalvi, Carbon dioxide hydrogenation catalysed by well-defined Mn(i) PNP pincer hydride complexes, Chem. Sci. 8 (2017) 5024-5029. https://doi.org/10.1039/c7sc00209b.

[120] S. Kar, A. Goeppert, J. Kothandaraman, G.K.S. Prakash, Manganese-Catalyzed Sequential Hydrogenation of $\mathrm{CO}_{2}$ to Methanol via Formamide, ACS Catal. 7 (2017) 6347-6351. https://doi.org/10.1021/acscatal.7b02066.

[121] C.-S. Li, G. Melaet, W.T. Ralston, K. An, C. Brooks, Y. Ye, Y.-S. Liu, J. Zhu, J. Guo, S. Alayoglu, G.A. Somorjai, High-performance hybrid oxide catalyst of manganese and cobalt for low-pressure methanol synthesis, Nat. Commun. 6 (2015) 6538. https://doi.org/10.1038/ncomms7538.

[122] H.S. Whang, J. Lim, M.S. Choi, J. Lee, H. Lee, Heterogeneous catalysts for catalytic CO2 conversion into value-added chemicals, BMC Chem. Eng. 1 (2019) 1-19. https://doi.org/10.1186/s42480-019-0007-7.

[123] J. Gao, Y. Wang, Y. Ping, D. Hu, G. Xu, F. Gu, F. Su, A thermodynamic analysis of methanation reactions of carbon oxides for the production of synthetic natural gas, RSC Adv. 2 (2012) 23582368. https://doi.org/10.1039/c2ra00632d.

[124] A. Atakan, Mesoporous material systems for catalysis and drug delivery, 2018.

[125] B. Dai, S. Cao, H. Xie, G. Zhou, S. Chen, Reduction of CO2 to CO via reverse water-gas shift reaction over $\mathrm{CeO}_{2}$ catalyst, Korean J. Chem. Eng. 35 (2018) 421-427. https://doi.org/10.1007/s11814-017-0267-y.

[126] N. Podrojková, V. Sans, A. Oriňak, R. Oriňaková, Recent Developments in the Modelling of Heterogeneous Catalysts for CO2 Conversion to Chemicals, ChemCatChem. 12 (2020) 18021825. https://doi.org/10.1002/cctc.201901879.

[127] S. Kattel, B. Yan, J.G. Chen, P. Liu, $\mathrm{CO}_{2}$ hydrogenation on Pt, $\mathrm{Pt} / \mathrm{SiO}_{2}$ and $\mathrm{Pt} / \mathrm{TiO}_{2}$ : Importance of synergy between Pt and oxide support, J. Catal. 343 (2016) 115-126. https://doi.org/10.1016/j.jcat.2015.12.019.

[128] J. Nakamura, T. Fujitani, S. Kuld, S. Helveg, I. Chorkendorff, J. Sehested, Comment on “Active sites for $\mathrm{CO}_{2}$ hydrogenation to methanol on $\mathrm{Cu} / \mathrm{ZnO}$ catalysts," Science (80-. ). 357 (2017) 1296- 
1299. https://doi.org/10.1126/science.aan8074.

[129] M. Minakshi Sundaram, A. Biswal, D. Mitchell, R. Jones, C. Fernandez, Correlation among physical and electrochemical behaviour of nanostructured electrolytic manganese dioxide from leach liquor and synthetic for aqueous asymmetric capacitor, Phys. Chem. Chem. Phys. 18 (2016) 4711-4720. https://doi.org/10.1039/c5cp07141k.

[130] H. Chen, S. Zeng, M. Chen, Y. Zhang, Q. Li, A new insight into the rechargeable mechanism of manganese dioxide based symmetric supercapacitors, RSC Adv. 7 (2017) 8561-8566. https://doi.org/10.1039/c6ra28040d.

[131] Z. Su, C. Yang, C. Xu, H. Wu, Z. Zhang, T. Liu, C. Zhang, Q. Yang, B. Li, F. Kang, Co-electrodeposition of the MnO2-PEDOT:PSS nanostructured composite for high areal mass, flexible asymmetric supercapacitor devices, J. Mater. Chem. A. 1 (2013) 12432-12440. https://doi.org/10.1039/c3ta13148c.

[132] H. Boumaiza, R. Coustel, G. Medjahdi, C. Ruby, L. Bergaoui, Conditions for the formation of pure birnessite during the oxidation of $\mathrm{Mn}$ (II) cations in aqueous alkaline medium, J. Solid State Chem. 248 (2017) 18-25. https://doi.org/10.1016/j.jssc.2017.01.014.

[133] A. Sápi, D.G. Dobó, D. Sebok, G. Halasi, K.L. Juhász, A. Szamosvölgyi, P. Pusztai, E. Varga, I. Kálomista, G. Galbács, A. Kukovecz, Z. Kónya, Silica Based Catalyst Supports Are Inert, Aren’t They? - Striking Differences in Ethanol Decomposition Reaction Originated from Meso- \&amp; Surface Fine Structure Evidenced by Small Angle X-ray Scattering, J. Phys. Chem. C. 121 (2017) 5130-5136. https://doi.org/10.1021/acs.jpcc.7b00034.

[134] A. Sápi, T. Rajkumar, M. Ábel, A. Efremova, A. Grósz, A. Gyuris, K.B. Ábrahámné, I. Szenti, J. Kiss, T. Varga, Á. Kukovecz, Z. Kónya, Noble-metal-free and Pt nanoparticles-loaded, mesoporous oxides as efficient catalysts for $\mathrm{CO} 2$ hydrogenation and dry reforming with methane, J. CO2 Util. 32 (2019) 106-118. https://doi.org/10.1016/j.jcou.2019.04.004.

[135] Z.A.T. Tepzz, E. Gregory, Tepzz 9¥z_6¥a_t (11), 1 (2015) 1-8.

[136] B. Donkova, D. Mehandjiev, Mechanism of decomposition of manganese(II) oxalate dihydrate and manganese(II) oxalate trihydrate, Thermochim. Acta. 421 (2004) 141-149. https://doi.org/10.1016/j.tca.2004.04.001.

[137] M. Cheong, I. Zhitomirsky, Electrophoretic deposition of manganese oxide films, Surf. Eng. 25 (2009) 346-352. https://doi.org/10.1179/174329408X281786.

[138] E.S. Ilton, J.E. Post, P.J. Heaney, F.T. Ling, S.N. Kerisit, XPS determination of Mn oxidation states in Mn (hydr)oxides, Appl. Surf. Sci. (2016). https://doi.org/10.1016/j.apsusc.2015.12.159.

[139] C.G. Pope, X-Ray Diffraction and the Bragg Equation, J. Chem. Educ. 74 (1997) 129. https://doi.org/10.1021/ed074p129.

[140] E. Silvester, A. Manceau, V.A. Drits, Structure of synthetic monoclinic Na-rich birnessite and hexagonal birnessite: II. Results from chemical studies and EXAFS spectroscopy, Am. Mineral. 82 (1997) 962-978. https://doi.org/10.2138/am-1997-9-1013.

[141] M. Wang, S. Yagi, Layered birnessite $\mathrm{MnO}_{2}$ with enlarged interlayer spacing for fast $\mathrm{Mg}$ - ion storage, J. Alloys Compd. (2019) 153135. https://doi.org/10.1016/j.jallcom.2019.153135.

[142] Q. Zhang, J. Luo, E. Vileno, S.L. Suib, Synthesis of Cryptomelane-Type Manganese Oxides by Microwave Heating, Chem. Mater. 9 (1997) 2090-2095. https://doi.org/10.1021/cm970129g.

[143] A. Dias, R.G. Sá, M.C. Spitale, M. Athayde, V.S.T. Ciminelli, Microwave-hydrothermal synthesis of nanostructured Na-birnessites and phase transformation by arsenic(III) oxidation, Mater. Res. Bull. 43 (2008) 1528-1538. https://doi.org/10.1016/j.materresbull.2007.06.019.

[144] C.M. Julien, M. Massot, C. Poinsignon, Lattice vibrations of manganese oxides: Part I. Periodic structures, Spectrochim. Acta - Part A Mol. Biomol. Spectrosc. 60 (2004) 689-700. https://doi.org/10.1016/S1386-1425(03)00279-8.

[145] A.C. Thenuwara, S.L. Shumlas, N.H. Attanayake, E.B. Cerkez, I.G. McKendry, L. Frazer, E. Borguet, Q. Kang, M.J. Zdilla, J. Sun, D.R. Strongin, Copper-Intercalated Birnessite as a Water Oxidation Catalyst, Langmuir. 31 (2015) 12807-12813. https://doi.org/10.1021/acs.langmuir.5b02936.

[146] P. Stelmachowski, P. Legutko, T. Jakubek, P. Indyka, Z. Sojka, L. Holmlid, A. Kotarba, Emission of highly excited electronic states of potassium from cryptomelane nanorods, Phys. Chem. Chem. Phys. 17 (2015) 26289-26294. https://doi.org/10.1039/c5cp04108b.

[147] G. Wang, G. Shao, J. Du, Y. Zhang, Z. Ma, Effect of doping cobalt on the micro-morphology and electrochemical properties of birnessite $\mathrm{MnO}_{2}$, Mater. Chem. Phys. 138 (2013) 108-113. https://doi.org/10.1016/j.matchemphys.2012.11.024.

[148] K. Fujiwara, K. Akedo, Y. Tasaki, A. Nakatsuka, N. Nakayama, Structure and Thermal Decomposition of $\mathrm{KxMnO}_{2} \cdot \mathrm{yH}_{2} \mathrm{O}$ Prepared by Sol-Gel Method, Trans. Mater. Res. Soc. Japan. 34 (2014) 447-450. https://doi.org/10.14723/tmrsj.34.447. 
[149] M.A. Cheney, P.K. Bhowmik, S. Qian, S.W. Joo, W. Hou, J.M. Okoh, A New Method of Synthesizing Black Birnessite Nanoparticles: From Brown to Black Birnessite with Nanostructures, J. Nanomater. 2008 (2008) 1-8. https://doi.org/10.1155/2008/763706.

[150] S.W. Joo, M.A. Cheney, P.K. Bhowmik, S. Moriuchi, M. Villalobos, S. Qian, The effect of stirring on the morphology of birnessite nanoparticles, J. Nanomater. 2008 (2008). https://doi.org/10.1155/2008/168716.

[151] L.X. Yang, Y.J. Zhu, G.F. Cheng, Synthesis of well-crystallized birnessite using ethylene glycol as a reducing reagent, Mater. Res. Bull. 42 (2007) 159-164. https://doi.org/10.1016/j.materresbull.2006.04.038.

[152] Q. Feng, E. Sun, K. Yanagisawa, N. Yamasaki, Synthesis of Birnessite-Type Reaction and Sodium Manganese Oxides by Solution Hydrothermal Methods of Hydrothermal Chemistry, J. Ceram. Soc. Jpn. 105 (1997) 564-568. https://doi.org/10.2109/jcersj.105.564.

[153] Garrison Sposito, Characterization of Particle Surface Charge, in: Environ. Part., Boca Raton, 1992.

[154] Lyklema, Fundamentals of Interface and Colloid Science, Vol. I, Academic Press, London, 1991.

[155] W. Janusz, A. Gałgan, Electrical Double Layer At Manganese Oxides/1:1 Electrolyte Solution Interface, Fizykochem. Probl. Miner. 35 (2001) 31-41.

[156] M. Kosmulski, Compilation of PZC and IEP of sparingly soluble metal oxides and hydroxides from literature, Adv. Colloid Interface Sci. 152 (2009) 14-25. https://doi.org/10.1016/j.cis.2009.08.003.

[157] Q. Feng, L. Liu, K. Yanagisawa, Effects of synthesis parameters on the formation of birnessitetype manganese oxides, J. Mater. Sci. Lett. 19 (2000) 1567-1570. https://doi.org/10.1023/A:1006733308073.

[158] N. Burgio, A. Iasonna, M. Magini, S. Martelli, F. Padella, Mechanical alloying of the Fe-Zr system. Correlation between input energy and end products, Nuovo Cim. D. 13 (1991) 459-476. https://doi.org/10.1007/BF02452130.

[159] G. Kozma, R. Puskás, I.Z. Papp, P. Bélteky, Z. Kónya, Kukovecz, Experimental validation of the Burgio-Rojac model of planetary ball milling by the length control of multiwall carbon nanotubes, Carbon N. Y. 105 (2016) 615-621. https://doi.org/10.1016/j.carbon.2016.05.005.

[160] T. Rojac, M. Kosec, B. Malič, J. Holc, The application of a milling map in the mechanochemical synthesis of ceramic oxides, J. Eur. Ceram. Soc. 26 (2006) 3711-3716. https://doi.org/10.1016/j.jeurceramsoc.2005.11.013.

[161] J. Joardar, S.K. Pabi, B.S. Murty, Milling criteria for the synthesis of nanocrystalline NiAl by mechanical alloying, J. Alloys Compd. 429 (2007) 204-210. https://doi.org/10.1016/j.jallcom.2006.04.045.

[162] C.X. Wu, S.G. Zhu, J. Ma, M.L. Zhang, Synthesis and formation mechanisms of nanocomposite WC-MgO powders by high-energy reactive milling, J. Alloys Compd. 478 (2009) 615-619. https://doi.org/10.1016/j.jallcom.2008.11.100.

[163] S. Qian, M.A. Cheney, R. Jose, A. Banerjee, P.K. Bhowmik, J.M. Okoh, Synthesis and characterization of birnessite and cryptomelane nanostructures in presence of hoffmeister anions, J. Nanomater. 2009 (2009). https://doi.org/10.1155/2009/940462.

[164] J. Zhu, J. He, Facile synthesis of graphene-wrapped honeycomb MnO 2 nanospheres and their application in supercapacitors, ACS Appl. Mater. Interfaces. 4 (2012) 1770-1776. https://doi.org/10.1021/am3000165.

[165] J. Yan, Z. Fan, T. Wei, W. Qian, M. Zhang, F. Wei, Fast and reversible surface redox reaction of graphene-MnO2 composites as supercapacitor electrodes, Carbon N. Y. 48 (2010) 3825-3833. https://doi.org/10.1016/j.carbon.2010.06.047.

[166] M. Aghazadeh, A. Bahrami-Samani, D. Gharailou, M.G. Maragheh, M.R. Ganjali, P. Norouzi, $\mathrm{Mn}_{3} \mathrm{O}_{4}$ nanorods with secondary plate-like nanostructures; preparation, characterization and application as high performance electrode material in supercapacitors, J. Mater. Sci. Mater. Electron. 27 (2016) 11192-11200. https://doi.org/10.1007/s10854-016-5239-1.

[167] M. Fang, X. Tan, M. Liu, S. Kang, X. Hu, L. Zhang, Low-temperature synthesis of $\mathrm{Mn}_{3} \mathrm{O}_{4}$ hollow-tetrakaidecahedrons and their application in electrochemical capacitors, CrystEngComm. 13 (2011) 4915-4920. https://doi.org/10.1039/c1ce05337j.

[168] C. Julien, M. Massot, R. Baddour-Hadjean, S. Franger, S. Bach, J.P. Pereira-Ramos, Raman spectra of birnessite manganese dioxides, Solid State Ionics. 159 (2003) 345-356. https://doi.org/10.1016/S0167-2738(03)00035-3.

[169] H. Liu, H. Zhang, L. Shi, X. Hai, J. Ye, Lattice oxygen assisted room-temperature catalytic process: Secondary alcohol dehydrogenation over Au/birnessite photocatalyst, Appl. Catal. A Gen. 521 (2016) 149-153. https://doi.org/10.1016/j.apcata.2015.10.027. 
[170] S. Chakrabarti, B.K. Dutta, R. Apak, Active manganese oxide: A novel adsorbent for treatment of wastewater containing azo dye, Water Sci. Technol. 60 (2009) 3017-3024. https://doi.org/10.2166/wst.2009.758.

[171] Q. Feng, K. Yanagisawa, N. Yamasaki, Synthesis of birnessite-type potassium manganese oxide, J. Mater. Sci. Lett. 6 (1997) 5-7. https://doi.org/10.1023/A:1018577523676.

[172] A.I. Zaitsev, M.A. Zemchenko, B.M. Mogutnov, Thermodynamic properties of manganese silicides, Zh. Fiz. Khim. 63 (1989) 1451-1458.

[173] A.M. El-Sawy, C.K. King’ondu, C.-H. Kuo, D.A. Kriz, C.J. Guild, Y. Meng, S.J. Frueh, S. Dharmarathna, S.N. Ehrlich, S.L. Suib, X-ray Absorption Spectroscopic Study of a Highly Thermally Stable Manganese Oxide Octahedral Molecular Sieve (OMS-2) with High Oxygen Reduction Reaction Activity, Chem. Mater. 26 (2014) 5752-5760. https://doi.org/10.1021/cm5028783.

[174] K.T. Jacob, A. Kumar, G. Rajitha, Y. Waseda, Thermodynamic data for $\mathrm{Mn}_{3} \mathrm{O}_{4}, \mathrm{Mn}_{2} \mathrm{O}_{3}$ and $\mathrm{MnO}$ 2, High Temp. Mater. Process. 30 (2011) 459-472. https://doi.org/10.1515/HTMP.2011.069.

[175] W.Y. Hernández, M.A. Centeno, S. Ivanova, P. Eloy, E.M. Gaigneaux, J.A. Odriozola, Cumodified cryptomelane oxide as active catalyst for $\mathrm{CO}$ oxidation reactions, Appl. Catal. B Environ. 123-124 (2012) 27-35. https://doi.org/10.1016/j.apcatb.2012.04.024.

[176] C. González, J.I. Gutiérrez, J.R. González-Velasco, A. Cid, A. Arranz, J.F. Arranz, Application of differential scanning calorimetry to the reduction of several manganese oxides, J. Therm. Anal. Calorim. 52 (1998) 985-989. https://doi.org/10.1023/A:1010132606114.

[177] Q. Xue, Q. Zhang, Agar hydrogel template synthesis of Mn 3 o 4 nanoparticles through an ion diffusion method controlled by ion exchange membrane and electrochemical performance, Nanomaterials. 9 (2019). https://doi.org/10.3390/nano9040503.

[178] J. Zhang, Y. Li, L. Wang, C. Zhang, H. He, Catalytic oxidation of formaldehyde over manganese oxides with different crystal structures, Catal. Sci. Technol. 5 (2015) 2305-2313. https://doi.org/10.1039/c4cy01461h.

[179] G.E. Mustoe, Density and loss on ignition as indicators of the fossilization of silicified wood, IAWA J. 37 (2016) 98-111. https://doi.org/10.1163/22941932-20160123.

[180] H. Al-Kelesha, M.I. Nasra, Reduction behavior of low grade iron ore at reducing conditions simulating different zones of blast furnace, Mater. Res. 22 (2019). https://doi.org/10.1590/19805373-MR-2018-0891.

[181] Z. Geng, Y. Wang, J. Liu, G. Li, L. Li, K. Huang, L. Yuan, S. Feng, $\delta-M n O 2-$ Mn3O4Nanocomposite for Photochemical Water Oxidation: Active Structure Stabilized in the Interface, ACS Appl. Mater. Interfaces. 8 (2016) 27825-27831. https://doi.org/10.1021/acsami.6b09984.

[182] D. Jampaiah, V.K. Velisoju, D. Devaiah, M. Singh, E.L.H. Mayes, V.E. Coyle, B.M. Reddy, V. Bansal, S.K. Bhargava, Flower-like $\mathrm{Mn}_{3} \mathrm{O}_{4} / \mathrm{CeO}_{2}$ microspheres as an efficient catalyst for diesel soot and CO oxidation: Synergistic effects for enhanced catalytic performance, Appl. Surf. Sci. 473 (2019) 209-221. https://doi.org/10.1016/j.apsusc.2018.12.048.

[183] Q. Si, M. Matsui, T. Horiba, O. Yamamoto, Y. Takeda, N. Seki, N. Imanishi, Carbon paper substrate for silicon-carbon composite anodes in lithium-ion batteries, J. Power Sources. 241 (2013) 744-750. https://doi.org/10.1016/j.jpowsour.2013.05.090.

[184] T. Gao, H. Fjellvåg, P. Norby, A comparison study on Raman scattering properties of $\alpha$ - and $\beta$ MnO2, Anal. Chim. Acta. 648 (2009) 235-239. https://doi.org/10.1016/j.aca.2009.06.059.

[185] A. Ochirkhuyag, A. Sápi, Á. Szamosvölgyi, G. Kozma, Á. Kukovecz, Z. Kónya, One-pot mechanochemical ball milling synthesis of the MnOx nanostructures as efficient catalysts for CO2 hydrogenation reactions, Phys. Chem. Chem. Phys. 22 (2020) 13999-14012. https://doi.org/10.1039/d0cp01855d.

[186] D. Jaganyi, M. Altaf, I. Wekesa, Synthesis and characterization of whisker-shaped MnO2 nanostructure at room temperature, Appl. Nanosci. 3 (2013) 329-333. https://doi.org/10.1007/s13204-012-0135-3.

[187] W. Tang, X. Yang, Z. Liu, K. Ooi, Preparation of $\beta-\mathrm{MnO} 2$ nanocrystal/acetylene black composites for lithium batteries, J. Mater. Chem. 13 (2003) 2989-2995. https://doi.org/10.1039/b306780g.

[188] , A. Zakeri, Dissolution Kinetics of Manganese Dioxide Ore in Sulfuric Acid in the Presence of Ferrous Ion, Iran. J. Mater. Sci. Eng. 4 (2007) 22-27.

[189] T. Sharma, Physico-chemical processing of low grade manganese ore, Int. J. Miner. Process. 35 (1992) 191-203. https://doi.org/10.1016/0301-7516(92)90033-S.

[190] M. Wang, L. Cheng, Q. Li, Z. Chen, S. Wang, Two-dimensional nanosheets associated with onedimensional single-crystalline nanorods self-assembled into three-dimensional flower-like 
Mn3O4 hierarchical architectures, Phys. Chem. Chem. Phys. 16 (2014) 21742-21746. https://doi.org/10.1039/c4cp03407d.

[191] B.Y. Xia, Y. Yan, N. Li, H. Bin Wu, X.W.D. Lou, X. Wang, A metal-organic framework-derived bifunctional oxygen electrocatalyst, Nat. Energy. 1 (2016) 1-8. https://doi.org/10.1038/nenergy.2015.6.

[192] C.O. Ania, M. Seredych, E. Rodriguez-Castellon, T.J. Bandosz, New copper/GO based material as an efficient oxygen reduction catalyst in an alkaline medium: The role of unique $\mathrm{Cu} / \mathrm{rGO}$ architecture, Appl. Catal. B Environ. 163 (2015) 424-435. https://doi.org/10.1016/j.apcatb.2014.08.022.

[193] G.G. Yadav, J.W. Gallaway, D.E. Turney, M. Nyce, J. Huang, X. Wei, S. Banerjee, Regenerable $\mathrm{Cu}$-intercalated $\mathrm{MnO} 2$ layered cathode for highly cyclable energy dense batteries, Nat. Commun. 8 (2017) 14424. https://doi.org/10.1038/ncomms14424.

[194] J. Ambrose, R.G. Barradas, D.W. Shoesmith, Investigations of copper in aqueous alkaline solutions by cyclic voltammetry, J. Electroanal. Chem. 47 (1973) 47-64. https://doi.org/10.1016/S0022-0728(73)80344-4.

[195] S. Ratso, I. Kruusenberg, M. Vikkisk, U. Joost, E. Shulga, I. Kink, T. Kallio, K. Tammeveski, Highly active nitrogen-doped few-layer graphene/carbon nanotube composite electrocatalyst for oxygen reduction reaction in alkaline media, Carbon N. Y. 73 (2014) 361-370. https://doi.org/10.1016/j.carbon.2014.02.076.

[196] Y. Li, K.A. Kuttiyiel, L. Wu, Y. Zhu, E. Fujita, R.R. Adzic, K. Sasaki, Enhancing Electrocatalytic Performance of Bifunctional Cobalt-Manganese-Oxynitride Nanocatalysts on Graphene, ChemSusChem. 10 (2017) 68-73. https://doi.org/10.1002/cssc.201601188.

[197] M. Vikkisk, I. Kruusenberg, S. Ratso, U. Joost, E. Shulg, I. Kink, P. Rauwel, K. Tammeveski, Enhanced electrocatalytic activity of nitrogendoped multi-walled carbon nanotubes towards the oxygen reduction reaction in alkaline media, RSC Adv. 5 (2015) 59495-59505. https://doi.org/10.1039/c5ra08818f.

[198] R.E. Davis, G.L. Horvath, The solubility a $\mathrm{n} d \mathrm{~d}$ i f f u s i o $\mathrm{n}$ coefficient of o $\mathrm{x} y \mathrm{~g}$ e $\mathrm{n}$ in potassium h y d r o x i d e solutions, Electrochimica.Acta. 12 (1967) 287. https://doi.org/http://dx.doi.org/10.1016/0013-4686(67)80007-0.

[199] H.A. Gasteiger, P.N. Ross, Oxygen Reduction on Platinum Low-Index Single-Crystal Surfaces in Alkaline Solution: Rotating Ring Disk Pt( $h k l$, Studies, J. Phys. Chem. 100 (1996) 6715-6721. https://doi.org/10.1021/jp9533382.

[200] M. Asahi, S.I. Yamazaki, S. Itoh, T. Ioroi, Electrochemical reduction of dioxygen by copper complexes with pyridylalkylamine ligands dissolved in aqueous buffer solution: The relationship between activity and redox potential, Dalt. Trans. 43 (2014) 10705-10709. https://doi.org/10.1039/c4dt00606b.

[201] Y. Wang, Y. Li, Z. Lu, W. Wang, Improvement of $\mathrm{O}_{2}$ adsorption for $\alpha-\mathrm{MnO}_{2}$ as an oxygen reduction catalyst by Zr4+ doping, RSC Adv. 8 (2018) 2963-2970. https://doi.org/10.1039/c7ra10079e.

[202] T.N. Lambert, J.A. Vigil, S.E. White, C.J. Delker, D.J. Davis, M. Kelly, M.T. Brumbach, M.A. Rodriguez, B.S. Swartzentruber, Understanding the Effects of Cationic Dopants on $\alpha-\mathrm{MnO}_{2}$ Oxygen Reduction Reaction Electrocatalysis, J. Phys. Chem. C. 121 (2017) 2789-2797. https://doi.org/10.1021/acs.jpcc.6b11252.

[203] T. Liu, Y. Yao, L. Wei, Z. Shi, L. Han, H. Yuan, B. Li, L. Dong, F. Wang, C. Sun, Preparation and Evaluation of Copper-Manganese Oxide as a High-Efficiency Catalyst for CO Oxidation and NO Reduction by CO, J. Phys. Chem. C. 121 (2017) 12757-12770. https://doi.org/10.1021/acs.jpcc.7b02052.

[204] F. Cheng, Y. Su, J. Liang, Z. Tao, J. Chen, MnO2-based nanostructures as catalysts for electrochemical oxygen reduction in alkaline media, Chem. Mater. 22 (2010) 898-905. https://doi.org/10.1021/cm901698s.

[205] I. Roche, E. Chaînet, M. Chatenet, J. Vondrák, Carbon-supported manganese oxide nanoparticles as electrocatalysts for the Oxygen Reduction Reaction (ORR) in alkaline medium: Physical characterizations and ORR mechanism, J. Phys. Chem. C. 111 (2007) 1434-1443. https://doi.org/10.1021/jp0647986.

[206] J. Feng, Y. Liang, H. Wang, Y. Li, B. Zhang, J. Zhou, J. Wang, T. Regier, H. Dai, Engineering manganese oxide/nanocarbon hybrid materials for oxygen reduction electrocatalysis, Nano Res. 5 (2012) 718-725. https://doi.org/10.1007/s12274-012-0256-8.

[207] H.Y. Su, Y. Gorlin, I.C. Man, F. Calle-Vallejo, J.K. Norskov, T.F. Jaramillo, J. Rossmeisl, Identifying active surface phases for metal oxide electrocatalysts: A study of manganese oxide bifunctional catalysts for oxygen reduction and water oxidation catalysis, Phys. Chem. Chem. Phys. 
14 (2012) 14010-14022. https://doi.org/10.1039/c2cp40841d.

[208] F.H.B. Lima, M.L. Calegaro, E.A. Ticianelli, Investigations of the catalytic properties of manganese oxides for the oxygen reduction reaction in alkaline media, J. Electroanal. Chem. 590 (2006) 152-160. https://doi.org/10.1016/j.jelechem.2006.02.029.

[209] X. Peng, Z. Wang, Z. Wang, Y. Pan, Multivalent manganese oxides with high electrocatalytic activity for oxygen reduction reaction, Front. Chem. Sci. Eng. 12 (2018) 790-797. https://doi.org/10.1007/s11705-018-1706-y.

[210] A.C. Garcia, F.H.B. Lima, E.A. Ticianelli, M. Chatenet, Carbon-supported nickel-doped manganese oxides as electrocatalysts for the oxygen reduction reaction in the presence of sodium borohydride, J. Power Sources. 222 (2013) 305-312. https://doi.org/10.1016/j.jpowsour.2012.08.049.

[211] C.J. Eom, D.Y. Kuo, C. Adamo, E.J. Moon, S.J. May, E.J. Crumlin, D.G. Schlom, J. Suntivich, Tailoring manganese oxide with atomic precision to increase surface site availability for oxygen reduction catalysis, Nat. Commun. 9 (2018) 1-7. https://doi.org/10.1038/s41467-018-06503-8.

[212] N. Garino, J. Zeng, M. Castellino, A. Sacco, F. Risplendi, M.R. Fiorentin, K. Bejtka, A. Chiodoni, D. Salomon, J. Segura-Ruiz, C.F. Pirri, G. Cicero, Facilely synthesized nitrogen-doped reduced graphene oxide functionalized with copper ions as electrocatalyst for oxygen reduction, Npj 2D Mater. Appl. 5 (2021) 1-10. https://doi.org/10.1038/s41699-020-00185-x.

[213] S.A. Mousavi, M. Mehrpooya, Fabrication of copper centered metal organic framework and nitrogen, sulfur dual doped graphene oxide composite as a novel electrocatalyst for oxygen reduction reaction, Energy. 214 (2021) 119053. https://doi.org/10.1016/j.energy.2020.119053.

[214] E. Alekseeva, T. Stelmashuk, S. Danilov, P. Yang, O. Levin, Bimetallic Cu/Pt oxygen reduction reaction catalyst for fuel cells cathode materials, Catalysts. 10 (2020) 1-14. https://doi.org/10.3390/catal10060667.

[215] H. Yu, A. Fisher, D. Cheng, D. Cao, Cu,N-codoped Hierarchical Porous Carbons as Electrocatalysts for Oxygen Reduction Reaction, ACS Appl. Mater. Interfaces. 8 (2016) $21431-$ 21439. https://doi.org/10.1021/acsami.6b04189.

[216] A. Macedo Andrade, Z. Liu, S. Grewal, A.J. Nelson, Z. Nasef, G. Diaz, M.H. Lee, MOF-derived $\mathrm{Co} / \mathrm{Cu}$-embedded $\mathrm{N}$-doped carbon for trifunctional ORR/OER/HER catalysis in alkaline media, Dalt. Trans. (2021). https://doi.org/10.1039/d0dt04000b.

[217] K. Stangeland, D.Y. Kalai, Y. Ding, Z. Yu, Mesoporous manganese-cobalt oxide spinel catalysts for $\mathrm{CO}_{2}$ hydrogenation to methanol, J. $\mathrm{CO}_{2}$ Util. 32 (2019) 146-154. https://doi.org/10.1016/j.jcou.2019.04.018.

[218] A. Sápi, G. Halasi, A. Grósz, J. Kiss, A. Kéri, G. Ballai, G. Galbács, Á. Kukovecz, Z. Kónya, Designed Pt Promoted 3D Mesoporous $\mathrm{Co}_{3} \mathrm{O}_{4}$ Catalyst in $\mathrm{CO}_{2}$ Hydrogenation, J. Nanosci. Nanotechnol. 19 (2018) 436-441. https://doi.org/10.1166/jnn.2019.15779.

[219] A. Sápi, G. Halasi, J. Kiss, D.G. Dobó, K.L. Juhász, V.J. Kolcsár, Z. Ferencz, G. Vári, V. Matolin, A. Erdöhelyi, Á. Kukovecz, Z. Kónya, In Situ DRIFTS and NAP-XPS Exploration of the Complexity of CO2 Hydrogenation over Size-Controlled Pt Nanoparticles Supported on Mesoporous NiO, J. Phys. Chem. C. 122 (2018) 5553-5565. https://doi.org/10.1021/acs.jpcc.8b00061.

[220] S. Kattel, P. Liu, J.G. Chen, Tuning Selectivity of CO2 Hydrogenation Reactions at the Metal/Oxide Interface, J. Am. Chem. Soc. 139 (2017) 9739-9754. https://doi.org/10.1021/jacs.7b05362.

[221] Q. Liu, Y. Han, J. Cai, E.J. Crumlin, Y. Li, Z. Liu, $\mathrm{CO}_{2}$ Activation on Cobalt Surface in the Presence of - H2O : An Ambient- Pressure X-ray Photoelectron Spectroscopy Study, Catal. Letters. 148 (2018) 1686-1691. https://doi.org/10.1007/s10562-018-2362-z.

[222] D.R.J. Kolling, N. Cox, G.M. Ananyev, R.J. Pace, G.C. Dismukes, What Are the Oxidation States of Manganese Required To Catalyze Photosynthetic Water Oxidation ?, 103 (2012) 313-322. https://doi.org/10.1016/j.bpj.2012.05.031.

[223] G. Varga, A. Sápi, T. Varga, K. Baán, I. Szenti, G. Halasi, R. Mucsi, L. Óvári, J. Kiss, Z. Fogarassy, B. Pécz, Á. Kukovecz, Z. Kónya, Ambient pressure $\mathrm{CO}_{2}$ hydrogenation over a cobalt/manganese-oxide nanostructured interface: A combined in situ and ex situ study, J. Catal. 386 (2020) 70-80. https://doi.org/10.1016/j.jcat.2020.03.028.

[224] J. Gómez-Pérez, D.G. Dobó, K.L. Juhász, A. Sápi, H. Haspel, Á. Kukovecz, Z. Kónya, Photoelectrical response of mesoporous nickel oxide decorated with size controlled platinum nanoparticles under argon and oxygen gas, Catal. Today. 284 (2017) 37-43. https://doi.org/10.1016/j.cattod.2016.10.026.

[225] H. Wang, K. An, A. Sapi, F. Liu, G.A. Somorjai, Effects of nanoparticle size and metal/support interactions in pt-catalyzed methanol oxidation reactions in gas and liquid phases, Catal. Letters. 
144 (2014) 1930-1938. https://doi.org/10.1007/s10562-014-1347-9.

[226] M.D. Porosoff, X. Yang, J.A. Boscoboinik, J.G. Chen, Molybdenum carbide as alternative catalysts to precious metals for highly selective reduction of $\mathrm{CO}_{2}$ to $\mathrm{CO}$, Angew. Chemie - Int. Ed. 53 (2014) 6705-6709. https://doi.org/10.1002/anie.201404109.

[227] R.W. Dorner, D.R. Hardy, F.W. Williams, H.D. Willauer, K and Mn doped iron-based $\mathrm{CO}_{2}$ hydrogenation catalysts: Detection of KAlH4 as part of the catalyst's active phase, Appl. Catal. A Gen. 373 (2010) 112-121. https://doi.org/10.1016/j.apcata.2009.11.005.

[228] H. Zhan, F. Li, C. Xin, N. Zhao, F. Xiao, W. Wei, Y. Sun, Performance of the La-Mn-Zn-Cu-O Based Perovskite Precursors for Methanol Synthesis from $\mathrm{CO}_{2}$ Hydrogenation, Catal. Letters. 145 (2015) 1177-1185. https://doi.org/10.1007/s10562-015-1513-8.

[229] B. Liang, T. Sun, J. Ma, H. Duan, L. Li, X. Yang, Y. Zhang, X. Su, Y. Huang, T. Zhang, Mn decorated $\mathrm{Na} / \mathrm{Fe}$ catalysts for $\mathrm{CO}_{2}$ hydrogenation to light olefins, Catal. Sci. Technol. 9 (2019) 456-464. https://doi.org/10.1039/c8cy02275e.

[230] S.S. Kim, K.H. Park, S.C. Hong, A study of the selectivity of the reverse water-gas-shift reaction over Pt/TiO2 catalysts, Fuel Process. Technol. 108 (2013) 47-54. https://doi.org/10.1016/j.fuproc.2012.04.003.

[231] R.E. Owen, D. Mattia, P. Plucinski, M.D. Jones, Kinetics of $\mathrm{CO}_{2}$ Hydrogenation to Hydrocarbons over Iron-Silica Catalysts, ChemPhysChem. 18 (2017) 3211-3218. https://doi.org/10.1002/cphc.201700422.

[232] Z.J. Liu, X.J. Tang, S. Xu, X.L. Wang, Synthesis and catalytic performance of graphene modified $\mathrm{CuO}-\mathrm{ZnO}-\mathrm{Al}_{2} \mathrm{O}_{3}$ for $\mathrm{CO}_{2}$ hydrogenation to methanol, J. Nanomater. 2014 (2014). https://doi.org/10.1155/2014/690514.

[233] P.A.U. Aldana, F. Ocampo, K. Kobl, B. Louis, F. Thibault-Starzyk, M. Daturi, P. Bazin, S. Thomas, A.C. Roger, Catalytic $\mathrm{CO}_{2}$ valorization into $\mathrm{CH}_{4}$ on Ni-based ceria-zirconia. Reaction mechanism by operando IR spectroscopy, Catal. Today. 215 (2013) 201-207. https://doi.org/10.1016/j.cattod.2013.02.019.

[234] H. Zhao, G. Han, Y. Chang, M. Li, Y. Li, The capacitive properties of amorphous manganese dioxide electrodeposited on different thermally-treated carbon papers, Electrochim. Acta. 91 (2013) 50-57. https://doi.org/10.1016/j.electacta.2012.12.114.

[235] N. devi, M. Goswami, M. Saraf, B. Singh, S.M. Mobin, R.K. Singh, A.K. Srivastava, S. Kumar, Physicochemical and electrochemical behaviours of manganese oxide electrodes for supercapacitor application, J. Energy Storage. 28 (2020) 101228. https://doi.org/10.1016/j.est.2020.101228.

[236] Z. Qi, A. Younis, D. Chu, S. Li, A Facile and Template-Free One-Pot Synthesis of $\mathrm{Mn}_{3} \mathrm{O}_{4}$ Nanostructures as Electrochemical Supercapacitors, Nano-Micro Lett. 8 (2016) 165-173. https://doi.org/10.1007/s40820-015-0074-0.

[237] J.W. Lee, A.S. Hall, J.D. Kim, T.E. Mallouk, A facile and template-free hydrothermal synthesis of $\mathrm{Mn}_{3} \mathrm{O}_{4}$ nanorods on graphene sheets for supercapacitor electrodes with long cycle stability, Chem. Mater. 24 (2012) 1158-1164. https://doi.org/10.1021/cm203697w.

[238] S.K. Nataraj, Q. Song, S.A. Al-Muhtaseb, S.E. Dutton, Q. Zhang, E. Sivaniah, Thin, flexible supercapacitors made from carbon nanofiber electrodes decorated at room temperature with manganese oxide nanosheets, J. Nanomater. 2013 (2013). https://doi.org/10.1155/2013/272093.

[239] P. Rosaiah, J. Zhu, O.M. Hussain, Y. Qiu, Synthesis of flower-like reduced graphene oxideMn3O4 nanocomposite electrodes for supercapacitors, Appl. Phys. A Mater. Sci. Process. 124 (2018) 1-9. https://doi.org/10.1007/s00339-018-2024-4.

[240] H. Yang, C. Zhang, P. Gao, H. Wang, X. Li, L. Zhong, W. Wei, Y. Sun, A review of the catalytic hydrogenation of carbon dioxide into value-added hydrocarbons, Catal. Sci. Technol. 7 (2017) 4580-4598. https://doi.org/10.1039/c7cy01403a.

[241] L. Jiang, M. Dong, Y. Dou, S. Chen, P. Liu, H. Yin, H. Zhao, Manganese oxides transformed from orthorhombic phase to birnessite with enhanced electrochemical performance as supercapacitor electrodes, J. Mater. Chem. A. 8 (2020) 3746-3753. https://doi.org/10.1039/c9ta12297d.

[242] Q. Li, X.F. Lu, H. Xu, Y.X. Tong, G.R. Li, Carbon/ $\mathrm{MnO}_{2}$ double-walled nanotube arrays with fast ion and electron transmission for high-performance supercapacitors, ACS Appl. Mater. Interfaces. 6 (2014) 2726-2733. https://doi.org/10.1021/am405271q.

[243] M. Sawangphruk, P. Srimuk, P. Chiochan, A. Krittayavathananon, S. Luanwuthi, J. Limtrakul, High-performance supercapacitor of manganese oxide/reduced graphene oxide nanocomposite coated on flexible carbon fiber paper, Carbon N. Y. 60 (2013) 109-116. https://doi.org/10.1016/j.carbon.2013.03.062.

[244] B.K. Kuila, S.M. Zaeem, S. Daripa, K. Kaushik, Mesoporous $\mathrm{Mn}_{3} \mathrm{O}_{4}$ coated reduced graphene 
oxide for high- performance supercapacitor applications Mesoporous $\mathrm{Mn}_{3} \mathrm{O}_{4}$ coated reduced graphene oxide for high- performance supercapacitor applications, (2018).

[245] A. Jänes, L. Permann, M. Arulepp, E. Lust, Electrochemical characteristics of nanoporous carbide-derived carbon materials in non-aqueous electrolyte solutions, Electrochem. Commun. 6 (2004) 313-318. https://doi.org/10.1016/j.elecom.2004.01.009.

[246] J.C.M. Costa, M.C. Nascimento, E.C. Silva, B.L. Pereira, R.R. Passos, L.A. Pocrifka, Galvanostatic synthesis of $\mathrm{MnO} 2$ in carbon cloth: an electrochemical impedance spectroscopy study, J. Solid State Electrochem. 24 (2020) 1727-1733. https://doi.org/10.1007/s10008-02004532-2.

[247] A.A. Yadav, Influence of electrode mass-loading on the properties of spray deposited $\mathrm{Mn}_{3} \mathrm{O}_{4}$ thin films for electrochemical supercapacitors, Thin Solid Films. 608 (2016) 88-96. https://doi.org/10.1016/j.tsf.2016.04.023. 


\section{Acknowledgements}

I would like to express my gratitude to my supervisor, Prof. Dr Zoltán Kónya for helping me research throughout the years and his optimistic perspectives always bringing me the motivation to do my best.

I would also like to thank Dr Csaba Janáky and Dr Sápi András for revising and helping the publication of my papers. I would also like to thank Balázs Buchholcz for introducing me to scientific work details when I arrived in Hungary and his support helped me to build my science journey.

I would like to thank my former and present colleagues in the Department of Applied and Environmental Chemistry, who shared their ideas, struggling, happiness with me, who participated in sports events, picnic, parties, and trips with me, without them 5 years' $\mathrm{PhD}$ journey would be too boring.

I am thankful for the financial support that was given by the Stipendium Hungaricum Scholarship by the Tempus Public Foundation and the Ministry of Foreign Affairs and Trade of Hungary.

I would like especially to thank my family, my parents and my friends who always believed in me and supported me all these years, without their support, I would not have stayed strong to finish my study. 


\section{Publication list}

Hungarian Scientific Bibliography (MTMT) identifier: 10066745

\section{Publications that are related to the PhD thesis:}

Ochirkhuyag Altantuya, Tamás Varga, Ildikó Y. Tóth, Ágnes Tímea Varga, András Sápi, Ákos Kukovecz, Zoltán Kónya

Cost-effective ion-tuning of Birnessite structures for efficient ORR electrocatalysts, International Journal of Hydrogen Energy, Volume 45, Issue 32, 11 June 2020, Pages 16266-1627 (Q1, impact factor: 4.939)

Number of independent citations: 2

Ochirkhuyag Altantuya, András Sápi, Ákos Szamosvölgyi, Gábor Kozma, Ákos Kukovecz and Zoltán Kónya

One-pot mechanochemical ball milling synthesis of the $\mathrm{MnO}_{x}$ nanostructures as efficient catalysts for $\mathrm{CO}_{2}$ hydrogenation reactions, Phys. Chem. Chem. Phys., 2020, 22, 1399914012 (Q1, impact factor: 3.430 )

Number of independent citations: 2

\section{Publication that is not directly related to the PhD thesis:}

Ochirkhuyag Altantuya, Ildikó Y. Tóth, Attila Kormányos, Csaba Janáky, and Zoltán Kónya

Composition-Dependent Optical and Photoelectrochemical Behavior of Antimony Oxide Iodides, Journal of the Electrochemical Society, Volume 166, Number 5 (Q1, impact factor: 3.721)

Number of independent citations: 1 


\section{Conference lectures and poster}

\section{Lectures:}

Ochirkhuyag Altantuya, Balázs Buchholcz, Ákos Kukovecz, Zoltán Kónya

"Synthesis and characterization of new antimony-oxide based photocatalysts", HSM Annual Meeting 2017, Siófok, Hungary

Ochirkhuyag Altantuya, Tamás Varga, Ildikó Tóth, Zoltán Kónya

Influence of a dopant on birnessite (manganese oxide) and electrochemical catalytic activity for oxygen reduction reaction (ORR), FEMS Junior EUROMAT conference, 812 July 2018, Budapest, Hungary

\section{Poster:}

Ochirkhuyag Altantuya, Tamás Varga, Ildikó Y. Tóth, Ágnes Tímea Varga, Ákos Kukovecz, Zoltán Kónya

"Influence of an interlayer cation exchange for birnessite and electrochemical activity for oxygen reduction reaction (ORR)", 8th Szeged International Workshop on Advances in Nanoscience (SIWAN 8), 7 - 10 October 2018, Szeged, Hungary 